\title{
THE EFFECTS OF COVID-19 ON U.S. SMALL BUSINESSES: EVIDENCE FROM OWNERS, MANAGERS, AND EMPLOYEES
}

\author{
Georgij Alekseev \\ Safaa Amer \\ Manasa Gopal \\ Theresa Kuchler \\ JW Schneider \\ Johannes Stroebel \\ Nils C. Wernerfelt \\ Working Paper 27833 \\ http://www.nber.org/papers/w27833 \\ NATIONAL BUREAU OF ECONOMIC RESEARCH \\ 1050 Massachusetts Avenue \\ Cambridge, MA 02138 \\ September 2020
}

Amer, Schneider, and Wernerfelt are employees at Facebook. Kuchler and Stroebel have a research consulting relationship with Facebook. The views expressed herein are those of the authors and do not necessarily reflect the views of the National Bureau of Economic Research.

NBER working papers are circulated for discussion and comment purposes. They have not been peer-reviewed or been subject to the review by the NBER Board of Directors that accompanies official NBER publications.

(C) 2020 by Georgij Alekseev, Safaa Amer, Manasa Gopal, Theresa Kuchler, JW Schneider, Johannes Stroebel, and Nils C. Wernerfelt. All rights reserved. Short sections of text, not to exceed two paragraphs, may be quoted without explicit permission provided that full credit, including $(\odot$ notice, is given to the source. 
The Effects of COVID-19 on U.S. Small Businesses: Evidence from Owners, Managers, and Employees

Georgij Alekseev, Safaa Amer, Manasa Gopal, Theresa Kuchler, JW Schneider, Johannes

Stroebel, and Nils C. Wernerfelt

NBER Working Paper No. 27833

September 2020

JEL No. G0,M1

\title{
ABSTRACT
}

We analyze a large-scale survey of owners, managers, and employees of small businesses in the United States to understand the effects of the early stages of the COVID-19 pandemic on those businesses. The survey was fielded in late April 2020 among Facebook business page administrators, frequent sellers on Facebook's e-commerce platform Marketplace, and the general Facebook user population. We observe more than 66,000 responses covering most sectors of the economy, including many businesses that had stopped operating due to the pandemic. The survey asks 136 questions covering topics such as changes in business operations and employment, changes in financing patterns, and the interaction of household and business responsibilities. We characterize the adjustments implemented to survive the pandemic and explore the key challenges to continue operating or to re-open. We show how these patterns differ across industry, firm size, owner gender, and other firm characteristics.

\author{
Georgij Alekseev \\ Stern School of Business \\ New York University \\ 44 West 4th Street \\ New York, NY 10012 \\ galeksee@stern.nyu.edu \\ Safaa Amer \\ Facebook \\ 1 Hacker Way \\ Menlo Park \\ safy@fb.com \\ Manasa Gopal \\ Scheller College of Business \\ Georgia Institute of Technology \\ 800 W Peachtree St NW \\ Atlanta, GA 30308 \\ manasa.gopal@scheller.gatech.edu \\ Theresa Kuchler \\ Stern School of Business \\ New York University \\ 44 West 4th Street \\ New York, NY 10012 \\ and NBER \\ tkuchler@stern.nyu.edu
}

JW Schneider

Facebook

1 Hacker Way

Menlo Park

jdub@fb.com

Johannes Stroebel

Stern School of Business

New York University

44 West 4th Street

New York, NY 10012

and NBER

johannes.stroebel@nyu.edu

Nils C. Wernerfelt

Facebook

1 Hacker Way

Menlo Park

nilsw@fb.com 


\section{INTRODUCTION}

The COVID-19 pandemic and associated public health interventions have led to substantial changes in business and work environments. Government orders forced businesses to close suddenly, infection risks led to an accelerated adaptation of modern sales and communication technologies, and school closures placed increased childcare duties on many working parents. These forces have put particular pressure on owners, managers, and employees of small businesses, where central responsibilities are often only shared between a small number of individuals. However, while these small businesses are a key driver of economic growth and employment in the U.S., as well as a central focus of many policy efforts, they are often underrepresented in traditional data sources (see Buffington, Dennis, Dinlersoz, Foster, and Klimek, 2020). This presents important challenges for researchers and policymakers hoping to understand the aggregate and distributional effects of large economic shocks such as COVID-19 on the performance of small businesses.

In this paper, we report findings from a large and comprehensive survey on the impact of the early stages of the COVID-19 pandemic on small businesses in the United States. The survey was conducted through the Facebook platform between April $20^{\text {th }}$ and April $28^{\text {th }}, 2020$. It was fielded among Facebook business page administrators, frequent sellers on its e-commerce platform Marketplace, and the general user population. This sampling frame allowed the survey to reach owners, managers, and employees of employer firms, as well as self-employed individuals. We were also able to survey a large number of businesses that had ceased operations during the survey period, which is central to understanding the challenges to small business survival. The survey contained 136 questions and obtained more than 66,000 responses - 46,669 from business owners or managers, 4,163 from operators of personal enterprises, and 15,435 from business employees - making it one of the largest undertakings to date to describe the effects of the COVID-19 crisis on U.S. small businesses. While no survey sample is fully representative, due to selection both in the sample that can be reached as well as in who responds, we find that our respondents broadly match the characteristics of small businesses in the U.S. as described by the Census Bureau.

The survey first asked respondents if they were an employee or whether they own, manage, or operate a business. Owners/managers were then asked whether their business was currently operational. These questions were used to direct respondents to different sections of the survey. Owners/managers of closed firms and business employees were asked to respond to a specific set of questions, while owners/managers of operational businesses were randomized into five thematic sets of questions covering business operations, business finances, the interaction of business and household responsibilities, business employees, and survival strategies. All owners/managers also answered a core set of demographic and business questions. A flowchart of the logical sequence of questions is provided in Figure 1, and full details on the survey methodology are provided in Section II. We next preview some central findings from the survey.

Open Businesses. First, we focus on businesses that were operational as of the survey date $(67.1 \%$ of our sample). Older businesses, larger businesses, and businesses with more male employees were more likely to be open. Among operational businesses, we explore several themes. 
Business Operations. We first document how business operations were affected by the pandemic. We find that most businesses $(60.9 \%)$ had seen their workload fall; those firms lost, on average, over half their business. We also document changes to standard business operations and virus containment measures. For example, we find that $61.7 \%$ of businesses had increased their online presence in response to the pandemic. About 55.9\% of businesses expected to survive if the conditions in late April were to continue longer than 6 months. Older businesses, majority-male businesses, and businesses that could operate remotely had more optimistic survival expectations.

Business Finances. We then provide a detailed exploration of small business finances during the pandemic, a feature that has not been the focus of other contemporaneous surveys, and is useful beyond the COVID-19 crisis. Many businesses were struggling to pay bills (31.3\%), rent (24.9\%), wages $(24.1 \%)$, and debt obligations $(23.0 \%)$. About $42 \%$ of businesses reported having more outflows than inflows in the past month, and $78.2 \%$ of businesses were concerned about cash flows over the next 3 months. Only a quarter of the businesses had access to formal sources of financing through a loan or line of credit from a financial institution, and most businesses were reliant on personal savings and informal sources of financing. We highlight heterogeneities in the sources of financing, especially across employer/non-employer firms and across business sectors. Finally, we show that deteriorating financial conditions, through lack of access to capital or negative cash flows, lead to a general decline in product prices.

Business and Household Responsibilities. A novel feature of our survey is the ability to explore household duties during the pandemic as well as their interaction with business work. $56.6 \%$ of managers and owners said that household responsibilities had impeded their business work; $55.0 \%$ reported that business responsibilities had affected their household duties. Owners/managers increased both their time spent on business work (57.1\%) and their housework (48.6\%). Specifically, they had increased their time spent on child education, daycare, and taking care of dependent adults. We look at how these effects vary by household characteristics and find that women and parents affected by school closures struggled the most.

Small Business Employees. Next, we explore employment patterns at small businesses from the employers' perspective. $44.5 \%$ of businesses reduced the number of active employees, using a combination of furloughs and layoffs; we find that firms with fewer in-person interactions were least likely to lay off workers. $29.3 \%$ of businesses could let all their employees work from home, while $37.1 \%$ could not let any of their employees do so. A majority of businesses reported providing their employees with protective equipment to reduce their exposure to the virus. Employers reported that female employees were more affected by the crisis than male employees.

Business Survival Strategies. We also explore the adjustments that businesses made to survive the pandemic. $52.5 \%$ of businesses responded to the crisis by providing online services, $35.1 \%$ expanded digital payments, $25.7 \%$ used delivery services, and $24.4 \%$ used curbside pickup. On the other hand, $36.1 \%$ of firms found it difficult to change the delivery of goods or services in response to the pandemic. Many businesses obtained their information about the pandemic through internet news sources (55.6\%) or social media (51.3\%). $25.4 \%$ of firms reported that they did not have all the information needed to make business decisions. 
Closed Businesses. We then analyze the $32.9 \%$ of firms that had ceased operations by the time of the survey in late April 2020. We examine their reasons for closure, their re-opening plans, their future employment and product plans, and the most important actions needed for re-opening. Among closed businesses, 57.5\% reported that they had shut down in response to government and health authority orders; $27.3 \%$ were unsure of whether they would re-open in the future. Closed businesses planned to use their personal savings to re-open (41.2\%) and often planned to make some changes to the products and services they offered prior to the closure $(23.3 \%)$.

Business Support. The final set of business questions was answered by both operational and closed businesses, and explores the biggest challenges faced by firms during the crisis as well as the policies that firms reported would be most helpful to survive the COVID-19 pandemic. The biggest challenge for $38.9 \%$ of businesses was accessing capital. Furthermore, many business owners and managers were feeling burnt out from taking care of both their business and their household. They also reported difficulties with processing information from contradictory sources. The most popular policy responses that businesses thought would support them through the crisis were salary subsidies, access to loan and credit guarantees, and tax deferrals.

Employees. Lastly, we surveyed employees about the impact of COVID-19 on their work and personal lives; this module includes responses from employees at businesses with more than 500 employees. $37.1 \%$ of workers reported having to take care of children due to school closures. Women were more likely to voluntarily quit their jobs in response to school closures and were more likely to report that household work was affecting their ability to focus on their jobs. The main challenges in working remotely were multi-tasking between work and household responsibilities $(28.9 \%)$, the nature of the work $(16.1 \%)$, and difficulty in collaborating remotely $(11.5 \%)$.

Related Literature. Our findings expand upon a growing body of research studying the economic implications of the COVID-19 pandemic, including several contemporaneous efforts to use surveys to better understand the performance of U.S. small businesses during this period. ${ }^{1}$ For example, Bartik, Bertrand, Cullen, Glaeser, Luca, and Stanton (2020); Fairlie (2020), and Humphries, Neilson, and Ulyssea (2020) document business closures and mass layoffs early in the pandemic (see also Bartlett, 2020; Campello, Kankanhalli, and Muthukrishnan, 2020). In addition to exploring the pandemic's effect on general business performance, our paper focuses on business responses affecting customers and employees, as well as changes in the interaction of household and work responsibilities. We also provide the perspectives of both small business owners/managers and their employees. We document important heterogeneities across affected firms, with a particular focus on exploring differences across owner gender and the ability to operate remotely. Women reported being more affected than men along a number of dimensions: the implementation of work from home might have a considerable impact on the distribution of household work, and school closures cause additional household burden (see also Alon, Doepke, OlmsteadRumsey, and Tertilt, 2020a,b; Carlson, Petts, and Pepin, 2020).

\footnotetext{
${ }^{1}$ Other research papers in the large emerging literature studying the economic effects of COVID-19 include Cox, Ganong, Noel, Vavra, Wong, Farrell, and Greig (2020); Giglio, Maggiori, Stroebel, and Utkus (2020); Kuchler, Russel, and Stroebel (2020b), and Coibion, Gorodnichenko, and Weber (2020).
} 


\section{Survey Methodology}

The survey was conducted alongside Facebook's ongoing data collection efforts with the World Bank and OECD on the Future of Business, and in partnership with the Small Business Roundtable. In this section, we describe the structure of the survey and the sampling methodology.

Sampling and Screening. The survey was fielded on the Facebook platform between April 20 and April 28, 2020, to a stratified probability-based random sample of Facebook users. ${ }^{2}$ Every monthly active U.S. Facebook account was eligible for the survey, ${ }^{3}$ though we oversampled accounts of Facebook business page administrators and active sellers on Facebook Marketplace. ${ }^{4}$ This sampling frame led to a high chance of identifying individuals who own or manage small businesses, many of which have a Facebook presence. Respondents from the general Facebook population were more likely to be employees, both at small and large enterprises.

Sampled users received an invitation to participate in a survey at the top of their newsfeed. This invitation was shown for three successive logins. After accepting the invitation, users were shown an introductory text and screening questions to understand their roles within the business (see Appendix Figure A.1 for more details). The introductory text described that participation in the survey was voluntary, that responses would be kept confidential, and that aggregated results from the survey might be shared publicly. There was no compensation of any kind.

The survey invitation was sent to about 1.9 million Facebook users, and 66,297 eligible individuals completed at least part of the survey: 46,669 business owners and managers, 4,163 operators of personal enterprises, and 15,435 business employees. There was no screening on firm size, though the sampling frame ensured that most respondents were associated with small businesses. Indeed, as we describe in detail in the following section, $68 \%$ of owner/manager respondents were associated with businesses with fewer than 10 employees (and 93\% were associated with businesses with fewer than 500 employees); on the other hand, about $25 \%$ of the employee sample worked at businesses with more than 500 employees. We verify that our findings are robust to excluding such firms and individuals.

\footnotetext{
${ }^{2}$ Facebook was created in 2004, and, by June 2020, had 2.7 billion active users around the world, and 256 million active users in the United States and Canada. An independent survey of Facebook users from 2019 found that more than $69 \%$ of the U.S. adult population used Facebook (Perrin and Anderson, 2019). That same survey shows that Facebook usage rates among U.S.-based online adults were relatively constant across income groups, education levels, and race, and among urban, rural, and suburban residents; usage rates were slightly declining in age (from $79 \%$ of individuals aged 18 to 29 , to $46 \%$ of individuals aged 65 and older). See Allen, Peng, and Shan (2020); Bailey, Cao, Kuchler, and Stroebel (2018); Bailey, Cao, Kuchler, Stroebel, and Wong (2018); Bailey, Dávila, Kuchler, and Stroebel (2019); Bailey, Farrell, Kuchler, and Stroebel (2020); Bailey, Gupta, Hillenbrand, Kuchler, Richmond, and Stroebel (2020); Bailey, Johnston, Kuchler, Russel, State, and Stroebel (2020); Bali, Hirshleifer, Peng, and Tang (2018); Kuchler, Russel, and Stroebel (2020a); Kuchler, Peng, Stroebel, Li, and Zhou (2020); Wilson (2019) and Rehbein and Rother (2020) for other economics and finance research using data from Facebook.

${ }^{3}$ Facebook generally does not allow accounts to receive multiple surveys in a short span of time. Since some of these surveys followed different sampling regimes (e.g., simple random or potentially targeted sampling), the total pool for our survey was not drawn completely at random from the overall Facebook population. In practice, reweighting for sampling (and non-response) moves the point estimates minimally, and the observable characteristics of our respondents align well with those from nationwide, offline estimates (see Tables 1 and 2).

${ }^{4}$ Facebook pages are profiles on Facebook specifically for businesses, brands, communities, or public figures. Each page must have an account tied to it as an administrator, and we oversampled those that were specifically from business pages. A business page is required for small businesses to advertise on Facebook. Facebook Marketplace is an ecommerce platform where users can buy and sell different products.
} 
Survey Instrument. The questionnaire was designed with a complex flow to reduce the burden on respondents while addressing a wide range of social and economic issues. A respondent could choose to skip any question in the survey with no prompts to answer, and the questionnaire flow would take them to the next logical question. The survey started with screening questions, followed by special modules and a core set of questions. Modules were assigned to respondents in a semi-random fashion based on their business role and whether their business was operational. The survey consisted of 136 possible questions but each respondent received a maximum of 30 questions for the longest path; since respondents could skip questions, the number of responses differs somewhat across questions. A flowchart detailing the different modules and possible paths through the survey is provided in Figure 1. We next present a brief overview of the survey path.

1. Respondents were asked a preliminary set of questions to classify their employment status, role in the firm, and operational status of the firm.

2. Based on work status, respondents were then classified as one of: business owners and managers, operators of personal businesses, or employees (employed or recently unemployed). ${ }^{5}$ Individuals not fitting any of these categories were not asked further questions.

3. Respondents who were categorized as business owners, business managers, or operators of personal businesses that were operational, were randomly assigned to one of five thematic modules.

4. Respondents who were categorized as business owners, business managers, or operators of personal businesses that were closed, were assigned their own question block.

5. Respondents who were categorized as employees (employed or unemployed) were given their own question block.

6. Finally, all respondents (both owners/managers and employees) answered questions about their demographics and firm characteristics.

\section{CHARACTERISTICS OF SAMPLED BUSINESSES}

A module on core business characteristics was answered by all respondents who identified as business owner or manager of a business, independent of whether the business was open or closed at the time of the survey. ${ }^{6}$ We start by presenting summary statistics of the sampled businesses.

Respondents were first asked about firm age, previous year revenue, sector, and location. Figure 2 presents these characteristics. Panel A shows that $9.9 \%$ of firms were less than a year old, $10.5 \%$ between one and two years, $17.3 \%$ between two and five years, and $62.2 \%$ were older

\footnotetext{
5 "Personal" businesses were defined as respondents who reported that they were "Self-employed providing goods or services" or that they "Produce goods sold for personal income" but did not otherwise self-identify as an owner or manager of a business. While there is no standard term for this category of businesses, they overlap a great deal with what are commonly called sole-proprietor or micro businesses.

${ }^{6}$ Specifically, this section was answered by individuals who chose "Manage day-to-day operations of a business", "Self-employed providing goods or services", "Produce goods sold for personal income", "Promote or sell goods or services", "Control business finances with authority to sign loans, leases, and contracts", "Own a business" or "Other business management or leadership activity" when asked about their activities during the past 3 months.
} 
than five years. Panel B shows the distribution of 2019 revenue for our sample. About 19.3\% of businesses had sales of less than $\$ 9,999$ in $2019,29.6 \%$ between $\$ 10,000-\$ 99,999,26.8 \%$ between $\$ 100,000-\$ 999,999$ and $19.9 \%$ had sales of over $\$ 1,000,000$. Finally, $4.2 \%$ of the firms surveyed were not operational in 2019. Panel C shows the sectors our firms operate in. These are services (33.1\%), retail and wholesale trade $(16.9 \%)$, hotels, cafes, and restaurants $(7.3 \%)$, information and communication $(6.2 \%)$, construction $(5.3 \%)$, manufacturing $(2.8 \%)$, transportation $(2.6 \%)$, and agriculture and mining (2.5\%). $23.1 \%$ of the surveyed firms did not self-classify into any of the above sectors. Finally, Panel D shows that our survey covers firms in urban (31.5\%), rural (23.6\%), and suburban areas (44.9\%). Table 1 compares our sample characteristics with the universe of businesses in the U.S. according to the U.S. Census Bureau's Business Dynamics Statistics (BDS).

We next describe the baseline operating conditions of the firms in our sample. Figure 3 explores employment characteristics before the start of the pandemic. Panel A shows that $29.6 \%$ of firms were sole-proprietorships, while $25.8 \%$ of firms had fewer than 5 employees. The remaining firms employed between 5-49 (28.3\%), 50-249 (7.1\%), and 250-499 (2.3\%) workers. Finally, $6.9 \%$ of firms were large businesses with over 500 employees. ${ }^{7}$ Our sample includes more femaleowned/managed businesses (56.9\%, Panel B), and Panel C shows that $31.6 \%$ of the businesses employed more women than men, $24.6 \%$ had an equal share of men and women, and $17.9 \%$ of firms had majority-male employment. ${ }^{8}$

Panel A of Figure 4 shows that $57.3 \%$ of firms turned a profit in the last quarter of $2019,22.1 \%$ broke even, and $16.7 \%$ made losses. To understand the impact of lockdown orders, we asked businesses about the extent to which business operations could be conducted remotely. Panel B documents that $32.4 \%$ of firms needed to conduct all of their interactions in-person, $17.2 \%$ more than half their interactions, and $10.3 \%$ half their interactions. On the other hand, $23.4 \%$ did not have any in-person employee-client interactions, and for an additional 16.7\% of firms, in-person interactions constituted less than half of their normal operations.

Panel A of Figure 5 shows that $67.1 \%$ of firms were operational at the time of the survey. We present results for operational firms in Section IV and results for closed firms in Section V. In Panels B to F of Figure 5, we present crosstabs of businesses' operational status by firm characteristics. Older businesses were more likely to be open (Panel B): $67.6 \%$ of firms older than 5 years were operating in late April, and 55.6\% of firms younger than a year. Similarly, consistent with Fairlie (2020), larger firms (measured by 2019 sales) were more likely to be operating: $83.5 \%$ of firms with sales over \$3 million in 2019 were operational, and 55\% of firms with sales below \$100,000 (Panel C). Manufacturing firms had coped the best, with $79.5 \%$ of firms operational, while businesses in the hotels, cafes, and restaurants sector fared the worst, with only $55.6 \%$ of firms operational in late April 2020 (Panel D). Businesses with a higher share of women have suffered more: 63.7\% of majority-female firms were operational, and 74.8\% of majority-male firms (Panel E). Finally, 52.5\% of firms that conduct all of their operations in-person were closed, and $26.6 \%$ of firms that did not require any in-person operations (Panel F).

Table 3 explores these relationships in a multivariate regression framework. Columns 1 to

\footnotetext{
${ }^{7}$ Information on the total number of employees before the pandemic was only surveyed for operational businesses.

${ }^{8}$ The remaining $25.9 \%$ stated "Not applicable", consistent with our sample's share of sole-proprietorships.
} 
4 show regressions with the businesses' operational status as dependent variable and controls only for firm age, sector, size, and share of in-person operations, respectively. They confirm the previous descriptive statistics. Column 5 includes all controls jointly. The effects of industry, firm sales, and remote work continue to impact businesses' operational status. However, the coefficient on male-owned/managed businesses drops by two-thirds and the impact of firm age disappears (in part because firm size and firm age are strongly correlated).

We also asked firms about their optimism for the future. Panel A of Figure 6 shows that, in late April 2020, 21.2\% of businesses were pessimistic, $19.6 \%$ had a neutral outlook, and $59.2 \%$ were optimistic about the future. Hotels, cafes, and restaurants had the worst outlook, with $51.6 \%$ reporting being optimistic (Panel B), while information and communication, and construction firms had the most positive outlook, with $63.0 \%$ and $61.8 \%$ feeling optimistic, respectively. The youngest firms ( $\leq 1$ year) were the most optimistic about the future $(62.7 \%$, Panel C). Panel D shows a Ushaped relationship between optimism and firm size: the smallest and largest firms by sales were more optimistic than medium-sized firms. Panel E suggests no meaningful differences in optimism by employee gender ratio. Finally, firms with less than half their operations in-person were more optimistic about the future $(63.7 \%)$ than firms with more than half their operations in-person (56.5\%, Panel F). Table 4 presents a multivariate regression of business optimism on firm characteristics. The dependent variable is equal to one if the respondent reported being optimistic. Columns 1 to 6 include controls for the firm's operational status, age, sector, sales, share of inperson interactions, and gender of the owner/manager, respectively. They confirm the previous descriptive statistics. Column 7 includes all regressors jointly; operational status, age, industry, firm size and remote-work ability continue to have a significant effect on business optimism.

\section{OPEN BUSINESSES}

We next explore various aspects about the performance and adjustments of businesses that were operating in late April 2020. All operational businesses were first asked about the biggest challenge they expected to face in the next few months. Figure 7 shows that their biggest concerns were cash flow (28.3\% of respondents), lack of demand $(21.7 \%)$, government or health authority orders (11.9\%), logistics (5.5\%), finding supplies (5.0\%), lack of staff (4.3\%), and inventory (3.6\%).

Table 5 looks at how firm characteristics affect the biggest perceived challenges of the businesses in our sample. The dependent variable takes a value of one in each column for each of the biggest challenges reported by the business. Cash flow problems were more likely to be the biggest challenge for medium-sized businesses as well as information, communication, hotel, cafe and restaurant businesses. Firms with a low share of in-person interactions and manufacturing firms often reported lack of demand. Government orders were most often stated by male-owned or managed businesses and businesses with a high share of in-person interactions. Finally, lack of staff was more likely to be the biggest problem among larger businesses.

After this question, respondents were randomly assigned to one of five modules to understand their business operations, finances, the interaction between work and household responsibilities, the impact on their employees, and their crisis survival strategy. We next review responses to each of these modules. 


\section{IV.A Business Operations}

We first explore how firms' workloads changed during the pandemic. Panel A of Figure 8 shows that $60.9 \%$ of firms experienced a drop in workload since the start of the pandemic. Of these firms, $48.0 \%$ said the drop was due to decreased demand or other customer-related reasons, and 33.6\% said it was due to government or health-authority orders (Panel B). On the flip side, $18.3 \%$ of firms saw increased workloads during the pandemic. These firms responded by extending operating hours (39.7\%), increasing supplies (19.7\%), and hiring more employees (18.8\%, Panel C).

Changes in workload vary by firm characteristics. Panel A of Figure 9 shows that larger firms were more likely to see increased workloads than smaller firms. Panel B shows that businesses in agriculture or mining were most likely to report increased workloads $(30.0 \%$ of firms in that sector), followed by businesses in the retail and wholesale trade (26.6\%). Sectors with the largest declines in workload were hotels, cafes, restaurants, as well as transportation and logistics. Panel $\mathrm{C}$ shows that firm age was not correlated with changes in workload. However, there is an inverse U-shaped relationship in firm size (Panel D): $59.5 \%$ of firms with sales between $\$ 100 \mathrm{k}-\$ 250 \mathrm{k}$ in 2019 saw reduced workload, compared with $43.3 \%$ of firms with sales $\leq \$ 5 \mathrm{k}$ and $46.5 \%$ of firms with sales $\geq \$ 3$ million. Majority-female firms were marginally more likely to see drops in workload than majority-male firms (54.9\% compared to 50.2\%, Panel E). Notably, they were also more likely to see an increase in workload (24.2\% compared to $19.5 \%)$. Finally, businesses with more in-person interactions saw drops in workload more often (Panel F): 59.7\% of firms with all their interactions in-person and $40.8 \%$ of firms with no in-person interactions reported declining workloads. Column 1 of Table 6 shows related estimates from a multivariate regression; the relations are similar, though the effects of firm size (sales) and gender balance become insignificant.

We also asked open businesses how the pandemic had affected their sales. Panel A of Figure 10 shows that $54.2 \%$ of firms said sales decreased in comparison to 2019 . On the other hand, sales remained steady for $13.7 \%$ of firms and increased for $16.3 \%$ of firms. Panel B shows that businesses with a drop in sales, on average, had seen sales fall by more than $50 \%$, and $11.6 \%$ of firms had seen a drop of over $90 \%$. On the other extreme, $17.5 \%$ of firms with increased sales saw their sales more than double, while $37.1 \%$ of the firms saw growth between $10-30 \%$. The heterogeneities in change in sales resemble the workload heterogeneities closely (see Appendix Section A.I, Appendix Figure A.3, and Appendix Table A.1), though 9\% of firms with increased sales had a lower workload, and $10 \%$ of firms with lower sales had a higher than normal workload.

Business Survival. Next, we look at how long operational businesses expected to survive if the conditions in April 2020 were to continue: 22.1\% expected to survive less than 6 months while $55.9 \%$ expected to survive for more than 6 months under prevailing conditions (Figure 11, Panel A). The remaining $22.1 \%$ of firms were unsure about their survival expectations. Figure 12 shows heterogeneity in business survival expectations. Larger businesses, older businesses and businesses with fewer in-person interactions had more optimistic survival expectations. Businesses in agriculture/mining had the highest survival expectations, while hotels, cafes, and restaurants were most pessimistic. Column 2 of Table 6 corroborates these observations in a multivariate framework, though the effects of firm age on survival expectations are statistically insignificant. 
Related to business survival, we asked businesses what support would be the most helpful in adapting to the pandemic (Panel B of Figure 11). Firms stated that the most helpful support would be zero-interest loans/financial assistance (46.9\%), equipment/software for remote work and customer engagement (14.7\%), or more information to facilitate business decisions (14.7\%).

Business Challenges and Responses. The following paragraphs provide more details on businesses' main challenges as well as their responses during the pandemic. Panel A of Figure 13 shows that $38.7 \%$ of businesses faced supply challenges. Panel B breaks up these supply challenges, and shows that firms were struggling with limited product supply (64.4\%), delayed supply shipments $(54.8 \%)$, and obtaining cleaning products $(36.4 \%)$.

Panel A of Figure 14 looks at changes to the business operations intended to mitigate the spread of the virus. The most common changes were to shift more business activities online (59.2\% of firms), more frequent cleaning (46.4\%), provision of PPE to employees (36.8\%), and increased work from home (35.8\%). Table 7 explores how firm characteristics were related to the implementation of virus response measures. Column 1 shows that increasing the online presence was more common for firms in the information and communication sector, larger firms, female-managed firms, and firms that rely less on in-person interactions. Hotels, cafes and restaurants, larger firms, firms with more in-person interactions, and female-managed firms responded by cleaning their work-spaces more frequently (Column 2). Hotels, cafes and restaurants, larger firms, and firms with more inperson interactions were also more likely to provide their employees with protective equipment (Column 3) and cleaning products for their clients (Column 4). Businesses in information and communication, larger businesses, and businesses that require less in-person interactions were more likely to shift to working from home (Column 5). Finally, larger businesses and femalemanaged businesses were more likely to have closed their physical locations (Column 6).

Panels B and C of Figure 14 explore changes to the standard business operations due to the pandemic. Overall, 75.7\% of firms implemented changes. These businesses changed their client interaction and communication methods $(65.3 \%)$, online tools $(46.4 \%)$, operating hours $(43.6 \%)$, and employee location (39.7\%). Table 8 explores how changes in business operations vary by firm characteristics. The dependent variables take a value of one if the business made a particular change. Client communication changed most for the largest firms and female-owned/managed firms (Column 1). Larger firms were also more likely to change their operating hours, as were restaurants and businesses that rely on more in-person interactions (Column 2). Firms that rely less on in-person interactions and female-owned/managed firms made increased use of online tools (Column 3) while also changing employees' work locations (Column 4). Larger and older businesses were also more likely to have changed their employees' locations.

\section{IV.B Business Finances}

This section explores the financial situation and financing sources of small businesses, both during the COVID-19 pandemic and more generally. Our paper is thus the first to focus on the financial conditions and financial challenges of small businesses during the COVID-19 crisis. ${ }^{9}$

\footnotetext{
${ }^{9}$ While Bartik, Bertrand, Cullen, Glaeser, Luca, and Stanton (2020) look at firms' cash at-hand and whether firms would take up schemes similar to the CARES act, our survey focuses on sources of existing capital at-hand, cash flow
} 
Payment Difficulties. First, we look at whether businesses were struggling to pay their expenses during the crisis. Panel A of Figure 15 shows that many firms were struggling to pay bills (31.3\% of firms), rent (24.9\%), employee wages (24.1\%), and debt commitments (23.0\%). On the other hand, $49.1 \%$ of firms reported no challenges in making any of these payments. Table 9 looks at how the business's struggles vary with firm characteristics. In each column, the dependent variable takes a value of one if the business was struggling to pay a particular type of obligation. Mid-sized firms and firms relying on in-person interactions to operate had the most difficulties paying their bills (Column 1). The largest firms and firms requiring in-person interactions were most worried about debt repayments (Column 2). Hotels, cafes and restaurants, and firms that cannot operate remotely struggled with paying wages and their taxes (Columns 3 and 5). The same firms, along with smaller firms, and firms in trade and services, were struggling to pay their rent (Column 4).

Formal and Informal Financing. Next, we explore the businesses' access to formal and informal sources of funding. Panel A of Figure 16 shows that $26.3 \%$ of firms had an outstanding loan or a credit line from a financial institution. However, Panels B and C highlight that access to financing varied significantly across employer and non-employer firms: $34.6 \%$ of employer firms had an outstanding loan, compared with only $11.7 \%$ of non-employer firms. The multivariate regression in Column 1 of Table 10 confirms that larger firms were more likely to have an outstanding bank loan; retail and service firms were less likely to have a loan.

We also explore whether firms applied for formal sources of funding during the pandemic. Panel A of Figure 17 shows that relatively few firms applied for government loans (31.4\%) and government grants (21.8\%). Only $14.4 \%$ of firms approached banks for financing during the pandemic, and $54.1 \%$ did not make any financing applications at all. Corroborating the differences in funding, employer firms were more likely to apply for any sources of capital than non-employer firms (57.4\% compared with 26.0\%). Columns 2 to 6 of Table 10 show that hotels, cafes, and restaurants were most likely to apply for funding from the government or private grants. Larger businesses were more likely to apply for funding from banks and government grants/loans.

Similarly, we looked at the prevalence of informal sources of funding. Figure 18 shows that the most common informal sources of funding for small businesses were personal savings (46.3\%), funds from friends and family (12.5\%), and unemployment benefits (9.7\%). However, 40.3\% of businesses did not have access to any private funds. Patterns were relatively similar across employer and non-employer firms, except for the more frequent occurrence of personal savings among non-employer firms. ${ }^{10}$ The multivariate analysis in Column 1 of Table 13 shows that businesses in construction, manufacturing, and transportation industries were least likely to have access to informal sources of financing. The largest firms (sales) were less likely to rely on personal

trends, financial struggles, and firms' responses through product pricing. A parallel paper by Campello, Kankanhalli, and Muthukrishnan (2020) studies the response through corporate hiring. However, their financial data is limited to large, public firms, while our paper is focused on studying small businesses.

${ }^{10}$ In Table 11, we look at the prevalence of internal vs. external financing by industry. We use the presence of bank loans or lines of credit as a measure of access to external financing (Sufi, 2007). We measure access to internal financing as access to personal savings, funds from family and friends, or retirement funds. The sectors with the largest share of firms with access to external financing are manufacturing $(42 \%)$, transportation $(38 \%)$, and construction (36\%). Retail firms are least likely to have access to external financing $(21 \%)$. The sectors with the largest share of firms with access to what we classify as internal financing are agriculture or mining (64\%), and information and communication (59\%). 
savings (Column 2) and family / friends (Column 3), but more likely to access unemployment benefits (Column 4). Male-owned firms were more likely to have access to personal savings. Finally, firms in the construction sector were less likely to receive community donations (Column 6).

Liquidity and Price Responses. Cash outflows were higher than inflows for $41.8 \%$ of businesses (Figure 19), especially for firms relying on in-person interactions (Table 14, Column 1). Most businesses (78.2\%) were concerned about their cash flow situation over the next 3 months (Figure 19, Panel B), especially hotels, cafes, restaurants, transportation firms, and firms relying on inperson interactions (Table 14, Column 2). Concerns were driven by reduced revenue (76.3\%), the inability to secure funds (22.9\%), and challenges in paying suppliers (17.9\%, Figure 19, Panel C).

$23.5 \%$ of firms reduced prices during the pandemic (Figure 20, Panel A); especially smaller firms (Table 14, Column 3). Panels B to E present crosstabs between firms' financial conditions and the response in product prices. Businesses with more outflows than inflows reduced their product prices more often $(29.2 \%)$ than firms with inflows greater than outflows (21.0\%). Similarly, firms that were very concerned about their cash flow situation over the next 3 months reduced prices more often $(33.2 \%)$ than firms that were not (11.0\%). Among the various cash flow concerns, businesses who were unable to secure funds were most likely to reduce prices $(33.0 \%)$, as were firms facing challenges in paying their suppliers (30.3\%). Furthermore, price decreases were more likely among firms that accessed crowdsourced capital (32.8\%) or applied for bank loans (27.3\%), than among firms that had not filed any financing applications (21.6\%).

Summarizing, our results persistently show that negative financial conditions, originating either through lack of access to capital or negative cash flows, have led firms to lower their product prices. These results are in line with Kim (2020) who shows that businesses facing a credit crunch temporarily decrease their prices.

Contribution. The insights from this survey are useful beyond understanding the immediate impact of the COVID-19 pandemic. In particular, information on the financial conditions of small private businesses has been largely unavailable in the United States. The best existing sources are the Survey of Small Business Finance (SSBF) and the FED Small Business Credit Survey. However, the SSBF has not been conducted since 2003. ${ }^{11}$ Meanwhile, in the last two decades, the financing sources of small businesses have significantly changed, with a decline in bank lending and a rise in nonbank sources of financing such as finance companies and FinTech lenders (Gopal and Schnabl, 2020). Our survey contributes by providing a timely snapshot of small business finances. We highlight the importance of informal sources of financing, thereby revealing information on businesses with no credit that are typically ignored in prior studies. ${ }^{12}$ The FED Small Business Credit Survey has been conducted annually since 2016. However, unlike our paper, they do not provide information on how financing conditions and business challenges vary by business and owner characteristics. Beyond that, our survey provides detailed information on access to financing, and responses of non-employer firms. ${ }^{13}$

\footnotetext{
${ }^{11}$ See Mach (2007) for detailed information on the coverage and usage of the SSBF.

${ }^{12}$ Conventional wisdom suggests that SMEs largely rely on internal financing and that the sources of financing vary with firm size and age (Berger and Udell, 1998). Our results corroborate this view. However, lack of detailed microdata on small business finances has made it hard to identify how access to external financing varies by industry.

${ }^{13}$ While the Small Business Credit Survey does provide reports on non-employer firms, the breadth of questions on
} 


\section{IV.C Business \& Household Responsibilities}

A special feature of the COVID-19 recession is that it came alongside a dramatically increased household burden for many individuals, due to a combination of school closures, requirements to quarantine, and the unavailability of hired domestic help. The third module of our survey, therefore, explores the interaction between business and household responsibilities. For reference, most respondents to our survey live with two to five other people $(63.5 \%)$, while $23.5 \%$ live with one other person (see Figure 21 for details).

Interaction of Business and Household. We first explore how the pandemic affected the ease of both business and household work, and the interaction between the two. Panel A of Figure 22 shows that $31.5 \%$ of business owners/managers stated that their household responsibilities affected their ability to focus on work during the crisis a lot. Interestingly, Panel B shows that respondents who could sometimes work remotely were the worst affected, as opposed to those who could work remotely all the time or never. Similarly, $28.9 \%$ of business owners/managers reported that business responsibilities had made it very difficult to take care of their household (Panel C), again with respondents who could sometimes work remotely doing worst (Panel D).

Table 15 explores how firm characteristics affect the owner/manager's ability to focus on their businesses and their households. The dependent variable takes a value of one if the manager reported struggling a lot or more in conducting their business or household work. Female owners/managers were most likely to struggle with focusing on their business due to household responsibilities; they were also more likely to report that their business responsibilities affected their ability to take care of their family members. In addition, managers of businesses that were more affected by the pandemic (hotels, cafes, and restaurants, larger firms, firms that require in-person interactions) were also finding it hard to focus on their household. This finding highlights that the financial struggles of small businesses during the COVID-19 pandemic had direct effects on the households of business owners and managers.

Household Activities. We further look at what activities respondents spent more time on since the start of the crisis. Panel A of Figure 23 shows that respondents were spending more time on business work (57.1\%), housework (48.6\%), education of children $(31.0 \%)$, care of self-isolating household members (17.8\%), and daycare (17.2\%). Overall, $54.8 \%$ of respondents spent less than 3 hours a day on domestic activities, though $18.9 \%$ spent at least 5 hours a day (Panel B).

Table 16 explores heterogeneities in these responses across firm characteristics. Male-managed and female-managed firms reported similar degrees of additional business work requirements (Column 1). However, female-managed firms reported a disproportional increase in the need to spend additional time on housework (Column 2), daycare (Column 3), and education for children (Column 4) in response to the crisis. In Column 5, we explore the number of hours spent on housework (rather than the incremental burden imposed by the pandemic). Female managers/owners and owners of smaller businesses reported spending more hours on household work.

Panel A of Figure 24 explores which home activities had the largest negative effect on the ability of owners to focus on their businesses. Respondents who spend more time caring for

sources of financing in our survey is significantly greater. 
household members have seen their ability to focus on the business being affected most strongly, e.g. due to child daycare (58.3\%), education for children $(50.7 \%)$, or caring for a dependent/selfisolating adult $(49.6 \% / 48.0 \%)$. Panel B shows that respondents who spent more hours a day on household work had a harder time focusing on their business responsibilities.

Household Expenses and Income. We also asked respondents whether they struggled to pay their usual household expenses in the past month. Panel A of Figure 25 shows that $35.4 \%$ of respondents said it was either difficult or very difficult. The Appendix looks at heterogeneities in these responses (Table A.2, Column 1) and finds that owners/managers struggling with making household expenses were more likely to work in firms most affected by the pandemic (i.e., restaurants, smaller businesses, and businesses that rely on in-person interactions). This highlights the close linkage between personal and business finances for owners and managers of small businesses.

Similarly, we asked business owners/managers what sources of money they had access to. Panel B of Figure 25 shows that 57.9\% reported that they were earning a salary, $55.1 \%$ had access to personal savings and $14.4 \%$ had access to income from a second business. In the Appendix, we verify that access to these additional income sources correlates with whether or not respondents had difficulties in paying usual household expenses (Table A.2, Column 2).

\section{IV.D Business Employees}

This section explores how business employees have been affected by the pandemic; it complements the information elicited directly from employees of small businesses, which we discuss in Section VII. Naturally, our sample for this module was restricted to employer businesses.

Layoffs, Furloughs, and Hires. Figure 26 presents information on business employment changes. $44.5 \%$ of employers reduced the number of employees as a result of the pandemic, while $4.0 \%$ of employers increased their workforce (Panel A). This finding is in agreement with Bartik, Bertrand, Cullen, Glaeser, Luca, and Stanton (2020), who highlight that many workforce reductions at small businesses had already occurred by late April. Among firms that decreased employment, 27.5\% laid off their workers, 30.0\% furloughed workers, and the rest did a combination of the two (Panel B). Firms reported that these employment changes affected their full-time workers (59.7\%), parttime workers $(45.3 \%)$, and contractors/outside consultants (27.2\%, Panel C). Finally, most firms stated that women and men were equally affected (53.4\%), though $13.3 \%$ said women were more affected, compared to $9.2 \%$ stating men were more affected (Panel D).

Figure 27 explores heterogeneities in the change of business employees by firm characteristics. Medium-sized firms were most likely to lay off workers, with 55.2\% of 10-49 employee firms reducing their workforce (Panel A). Furthermore, the likelihood of increasing the workforce increased with firm size: $11.8 \%$ of 250-499 employee firms hired employees while only $1.7 \%$ of the smallest firms did. This finding is corroborated by Campello, Kankanhalli, and Muthukrishnan (2020), who argue that small firms nearly halted their hiring. Panel C confirms the stronger impact on female employment during the pandemic; $47.4 \%$ of majority-female firms decreased their workforce, compared to $40.6 \%$ of majority-male firms. Finally, being able to work from home was associated with fewer layoffs: $22.4 \%$ of firms where all employees could be working from home reduced their workforce, compared with $51.5 \%$ of firms where no employees could do so. 
Working from Home. Panel A of Figure 28 shows that at $29.3 \%$ of businesses all employees were able to work from home for more than a few days, while $37.1 \%$ of firms could not facilitate any remote work at all. Among firms that permitted work from home, 88.7\% provided at least some of their workers with equipment/resources to support their remote work (Panel B). Column 1 of Table 17 shows that firms in information and communication industries and firms with fewer in-person interactions were more likely to allow employees to work from home. This finding supports the evidence in favor of remote work being more widespread among industries with more educated workers (Bartik, Cullen, Glaeser, Luca, and Stanton, 2020). ${ }^{14}$ Female-managed firms were also more likely to allow employees to work from home (Table 17, Column 1) and manufacturing firms were least likely to provide workers remote work support (Column 2). Crosstabs are shown in the Appendix Figure A.2.

Worker Safety. We also asked firms how they were ensuring the safety of their workers. Panel A of Figure 30 shows that $45.3 \%$ of firms said that the COVID-19 exposure of their employees while working was low; $23.3 \%$ and $14.2 \%$ rated the risk as medium and high, respectively. Column 3 of Table 17 shows that male-owned firms and firms with fewer in-person interactions were less likely to report a high risk of exposure to the virus. Panel B of Figure 30 shows that businesses with low exposure risk were more likely to be optimistic about the future than businesses with high exposure risk (66.5\% compared with $60 \%$ saying they were optimistic).

Panel C of Figure 30 shows that firms reduced their employees' exposure to the virus by providing hand sanitizer $(63.0 \%)$, alcohol or disinfectant wipes $(54.0 \%)$, disposable gloves $(51.4 \%)$, and protective masks (50.5\%). They also provided monetary compensation by giving paid-timeoff $(36.4 \%)$, health insurance (35.0\%), and sick leave (32.9\%, Panel D). Column 4 of Table 17 explores firm characteristics associated with providing employee compensation. Larger firms and firms with fewer in-person interactions were more likely to provide compensation, whereas restaurants, cafes, and hotels were less likely to do so.

Finally, we look at how employee risk correlates with business employment changes, protective measures, and pay. Panel A of Figure 31 shows that firms that reported a higher infection risk at work reduced their workforce more often. Panel B does not reveal an increased use of a particular type of protective measure among high-risk firms. Lastly, Panel C shows that high-risk firms were more likely to compensate employees with hazard pay: $26.8 \%$ of firms providing hazard pay were high risk compared to $12.9 \%$ of firms that did not provide any additional support.

\section{IV.E Business Survival Strategy}

The last of the five randomized modules only shown to operational businesses asked business owners/managers about their strategies to adjust to and survive the pandemic.

Client Adjustments. Panel A of Figure 32 shows that $80.6 \%$ of firms had to make changes to accommodate their clients' needs during the pandemic. Panel B shows that these changes include providing online services (52.5\% of firms), expanding digital payments (35.1\%), offering delivery

\footnotetext{
${ }^{14}$ Moreover, we compared the self-reported share of employees that could be working from home and the estimated share by Dingel and Neiman (2020) by industry (see Figure 29 and Table 12). We assumed a share of 100\%, 75\%, 50\%, $25 \%$ and $0 \%$ if the respondent stated that "all", "more than half", "about half", "less than half", and "none" could work remotely, respectively. The statistics match very well with a Pearson correlation coefficient of $80.5 \%$.
} 
services (25.7\%), and offering curbside pickup (24.4\%). Table 18 explores how firm characteristics affected the changes undertaken. Hotels, cafes, and restaurants, and retail firms were most likely to provide delivery services and curbside pickup. Firms that rely on in-person interactions were more likely to provide delivery and curbside pickup. Service firms were more likely to shift to online services and less likely to provide curbside pickup.

Business Model Adjustments. Figure 33 looks at adjustments to the firms' business models. Panel A shows that $30.9 \%$ of firms made all of their sales online in the prior 30 days and another $27.8 \%$ of firms made more than half their sales online. Panel B shows that firms used many tools to continue operations, in particular their website (53.9\%), online advertising (51.9\%), customer communication tools (47.1\%), and digital payments (43.9\%). Panel C explores different approaches to ensuring the availability of needed supplies during the pandemic: $23.5 \%$ of firms adjusted their order schedules, $21.0 \%$ changed their delivery procedures, and $19.9 \%$ delayed orders. At the same time, Panel D shows that $36.1 \%$ of firms reported that it has been difficult to change the delivery of goods or services as a result of the pandemic.

Table 19 shows that hotels, cafes, and restaurants, and retail businesses were most likely to use online advertising. The transportation industry and old firms were least likely to use online advertising or digital payment tools (Columns 1 and 2). A high share of in-person interactions was also associated with a lower likelihood of using digital payment tools. Order schedules and delivery processes were most often adjusted by large businesses, and least often by information and communication businesses (Columns 3 and 4). Finally, small businesses, businesses with few in-person interactions, and businesses in information and communication had the least difficulties in changing the delivery of their goods and services (Column 5).

Information Sources. Panel A of Figure 34 shows that $65.5 \%$ of managers/owners believed they had sufficient information to make business decisions during the pandemic, though $22.8 \%$ reported not having all the information needed. Most firms received their information about how they could get support during the pandemic from government sources (57.5\%), news on the internet (55.6\%), social media (51.3\%), and TV news (44.2\%, Panel B). Panels C to F of Figure 34 explore heterogeneities in information availability by firm characteristics. Column 6 of Table 19 explores these relationships in a regression framework. Firms with a high share of in-person interactions and female-owned/managed firms were more likely to report insufficient information.

Finally, in Appendix Section A.II and Figure A.4, we explore how business tools, client accommodations, and information sources vary with the share of revenues coming from online sales.

\section{Closed Businesses}

Up until now, our results have focused on the set of businesses that continued to operate by the time of our survey in late April 2020. In this section, we focus on the set of businesses that ceased operations. In particular, 16,147 respondents (32.9\% of firms in our sample) reported closing their businesses during the pandemic. Of these, 19.1\% closed in February, 59.5\% closed in March, and 11.3\% shut after April 1st (Figure 35, Panel A). Panel B explores how owners/managers spent their time during business closure. Common activities included planning for the re-opening (56.1\%), 
setting up an online website (26.9\%), taking business-related courses or training $(21.6 \%)$, securing funding $(20.3 \%)$, and looking for a job (19.7\%).

Reasons for Closing. Panel C of Figure 35 shows that most businesses reported closing due to government and health authority orders (61.7\%), financial challenges (7.7\%), and customer-related reasons (6.9\%). Table 20 explores how the reasons for firm closure varied by firm characteristics. Larger firms (sales) and firms relying on in-person interactions were more likely to have closed due to government orders (Column 1). Younger and smaller firms were more likely to have shut due to financial challenges (Column 2). Firms relying less on in-person interactions were more likely to report client-related reasons for closure (Column 3).

Plans for Re-Opening. Panel A of Figure 36 shows that most businesses (67.9\%) planned to reopen in the future, while $27.3 \%$ were unsure, and $4.9 \%$ reported that they did not plan to re-open. The reasons for closure were related to firms' expectations of re-opening. Panel B documents that businesses that closed due to government orders, customer-related reasons, or because they were facing logistical challenges were most likely to plan to re-open, with $70.2 \%, 68.6 \%$ and $68.9 \%$, respectively, responding in the affirmative. On the other hand, only $48.3 \%$ of businesses facing financial challenges said they would re-open in the future. Panel C of Figure 36 shows that the main reasons given for not re-opening were being unable to pay bills or rent $(31.4 \%)$, personal reasons $(15.6 \%)$, and debt payments $(10.0 \%)$.

We asked businesses that planned to re-open or that were unsure about their future re-opening about the most important actions required for the business to re-open. Panel D of Figure 36 shows the results. The most common required actions were government permission to operate (55.5\%), securing funding $(21.5 \%)$, changing the business activities $(4.9 \%)$, better understanding the market $(4.0 \%)$, and hiring skilled workers (1.1\%). Table 21 looks at how firm characteristics affect firms' most important reason for re-opening. Larger firms and firms in the service sector were more likely to report requiring government permission to open (Column 1). Younger firms, smaller firms, and male-managed firms were more likely to report the need to secure funds (Column 2).

To finance their re-opening, $42.4 \%$ of businesses planned to use their personal savings (Figure 36, Panel E). Other owners/managers were planning to borrow on their credit card (15.7\%) or make use of their firm assets (15.0\%). However, a large fraction of respondents, $42.4 \%$, did not know how they were going to fund their re-opening.

Lastly, we asked respondents about their plans for the re-opened businesses. The products will stay the same for $69.0 \%$ of firms, while $23.3 \%$ of firms planned to make some changes to the products and services they offered prior to the closure (Figure 37, Panel A). Column 3 of Table 21 shows that businesses with fewer in-person interactions were more likely to plan changes in offered products; construction firms were least likely to do so. $41.8 \%$ of firms planned to re-hire the same employees or workers as before for the re-opening and $14.9 \%$ were retaining their employees and paying them at least a part of their wages during the closure (Figure 37, Panel B).

Appendix Section A.III and Figure A.5 further explore how the most important action for re-opening and future products differ by closing reason. 


\section{Business Support NeEdS}

The final section answered by business owners/managers further explores the challenges they were facing during the pandemic and asks them about the policies that would optimally help them going forward. These questions were shown to all open and closed businesses we surveyed.

Biggest Challenges. Panel A of Figure 38 explores firms' biggest challenges during the pandemic. Access to capital/funding was the biggest challenge for $38.9 \%$ of businesses, especially for restaurants, cafes, and hotels, younger firms, and male-owned/managed firms (Table 22, Column 1). Of these, $46.9 \%$ were afraid of borrowing money because they could not pay it back, and $25.3 \%$ did not know where to get the money they required to keep their business open (Figure 39, Panel A).

Worries brought on by their employees were the main challenge for $15.2 \%$ of firms. This concern was particularly common among larger firms, older firms, and firms with more in-person interactions (Table 22, Column 2). Among firms reporting this to be their primary challenge, 33.5\% were concerned about not doing the type of work that allowed employees to work from home, and 27.2\% were worried about the exposure of their employees to the virus (Figure 39, Panel B).

Government interventions and regulations were the biggest worries for $14.5 \%$ of businesses. These businesses were more likely to be large, to require more in-person interactions, and to be male-owned/managed (Table 22, Column 3). Panel C of Figure 39 shows that this concern was driven by government-imposed regulations that were required to keep the business open (30.5\%), or because their business had been designated as non-essential and had to be closed (18.1\%).

A further $10.8 \%$ of respondents stated that taking care of household members was their biggest challenge. This was true especially for respondents from female-owned/managed firms (Table 22, Column 4). Panel D of Figure 39 shows that these respondents felt burnt out taking care of both their firm and household (47.6\%), were afraid of bringing the virus home $(27.0 \%)$, and were concerned about their inability to find someone to take care of their children's education (15.0\%).

Using online tools was the biggest challenge for $8.7 \%$ of respondents. These tended to be owners or managers from smaller firms, from businesses that relied on fewer in-person interactions, or from female-managed firms (Table 22, Column 5). Of these respondents, $28.0 \%$ were overwhelmed by the amount of resources available online, and $22.3 \%$ did not know about the tools to support businesses available online (Figure 39, Panel E).

Finally, 3.8\% of respondents stated that gathering information was their biggest challenge, especially owners/managers of smaller firms (Table 22, Column 6). For these individuals, the dominant issue (53.2\%) was the high amount of contradictory information (Figure 39, Panel F).

Support Policies. We then asked businesses which three policies would help them the most in surviving the pandemic. Panel B of Figure 38 shows that the most commonly requested support policies were salary subsidies (42.7\%), access to loan guarantees (41.1\%), tax deferral (33.7\%), loan repayment deferral $(29.3 \%)$, rent deferral $(29.1 \%)$, utility subsidies $(26.0 \%)$, and support in taking care of household members $(25.1 \%)$. Table 23 explores how suggested policies varied by firm characteristics. The dependent variable takes a value of one if the respondent mentioned a policy as one of the three main policies that would be beneficial in supporting the business. Larger firms, female-owned/managed firms, and firms that relied on more in-person interactions were 
more likely to request salary subsidies (Column 1). Male-owned/managed firms and younger firms were more likely to request access to loan guarantees (Column 2). Tax deferrals were most popular among mid-sized, male-owned/managed, and construction firms (Column 3).

\section{EMPLOYEES}

While the previous sections focused on the perspective of business owners and managers, in the final section, we focus on the responses of 15,435 self-reported employees. The results in this section are based on all employee respondents in our survey, including the approximately $25 \%$ of employees working for firms with more than 500 employees. For completeness, Appendix Section A.VI reproduces all graphs in this section while excluding employees working for firms with more than 500 employees. We conclude that they do not affect any of the patterns we highlight below.

Employee Demographics. Appendix Figures A.6, A.7, A.8 and A.9 provide information on the employees' ages, educational qualifications, locations, sectors of employment, and the type of workers covered by our sample. Table 2 shows that, on average, our sample corresponds relatively closely to the characteristics of U.S. employees. A few noticeable differences include the larger share of female workers in our sample $(63.3 \%$ vs. $58.2 \%)$, as well as more employees from the information/communication sector ( $8.5 \%$ vs. $1.8 \%)$ and the services sector $(17.4 \%$ vs. $12.4 \%)$.

Recently Unemployed. We first explore the responses of individuals that had worked at some point during the last three months but were unemployed as of late April 2020. This applies to $26.3 \%$ of individuals in our employee sample. ${ }^{15}$

Panel A of Figure 40 shows that the primary reasons for unemployment were business closures $(40.4 \%)$ or layoffs by the former employer $(24.4 \%)$ due to the pandemic. $7.6 \%$ stated their unemployment was due to a reason other than the pandemic. $4.1 \%$ of respondents reported that they could not work because they had to educate their children at home. Panel B of Figure 40 shows that this reason was given by $4.6 \%$ of the unemployed women and only $2.3 \%$ of the unemployed men, confirming the impact of school closures on gender inequalities (see Alon, Doepke, Olmstead-Rumsey, and Tertilt, 2020b).

Next, we look at the demographics of unemployed individuals (Figure 41). Self-reported unemployment was more common among less educated, younger, and older respondents; it was lowest within the age group of 36-45 years. Moreover, respondents that worked at smaller firms were more likely to be unemployed: $29.5 \%$ of former sole-proprietorships compared to $11.9 \%$ of workers that worked at large businesses ( $\geq 500$ employees) were unemployed.

Figure 42 explores what individuals were doing while being unemployed. $17.8 \%$ of workers reported doing nothing, $17.7 \%$ were homeschooling children, $13.6 \%$ were looking for a job in another sector, and $4.2 \%$ were taking business-related training.

Panel A of Figure 43 shows that $32.3 \%$ of the unemployed were receiving government assistance, with the most common being unemployment benefits (65.8\%, Panel B). However, 58.3\% of the unemployed had not applied for any government/NGO assistance by late April 2020. Of

\footnotetext{
${ }^{15}$ Note that this measure is not comparable to the official unemployment rate in the U.S. - we do not include respondents that have been unemployed for longer than three months, account for job search, job availability or active duty forces, or restrict age. For reference, see: https://www.bls.gov/cps/cps_htgm.htm.
} 
those, Panel C shows, many mentioned being ineligible $(24.7 \%)$ or not knowing the application procedures (24.8\%). $28.5 \%$ of respondents stated they did not need to apply for assistance.

Employees $\mathcal{E}$ Household Responsibilities. Similar to our analysis of small business owners and managers, Figure 44 shows that many households faced increased care burdens during the COVID19 crisis. School closures increased the burden of care for school-aged children: $27.5 \%$ of respondents served as primary caregivers and $9.6 \%$ as non-primary caregivers (Panel A). Similarly, Panel $\mathrm{B}$ shows that for $10.8 \%$ of respondents, the pandemic also necessitated additional care of dependent adults. Care duties were not distributed equally across the population $-33.4 \%$ of women were primary caregivers of school-age children and 6.2\% were non-primary caregivers, compared to $19.7 \%$ and $15.1 \%$ of men, respectively.

Household activities affected the ability of employees to focus on their job a lot or more for $24.2 \%$ of workers (Figure 45, Panel A). That share was $15.6 \%$ for workers without children, and increases to $42.5 \%$ for primary caregivers and $27.2 \%$ for non-primary caregivers of children affected by school closures (Panel B). Similarly, women were more likely than men to report that household responsibilities were significantly affecting their ability to focus on work (26.2\% compared to $19.2 \%$, Panel C); the most affected age group were between $36-45$ years (30.1\%, Panel D).

Perhaps surprisingly, employees that work remotely some of the time reported most often $(32.3 \%)$ to have their jobs affected, compared to employees that could not work remotely at all $(23.0 \%)$ and employees that could work remotely all the time (20.3\%, Figure 45 , Panel E). This is consistent with patterns found among business owners and managers (see Figure 22).

Column 1 of Table 24 looks at these heterogeneities in a multivariate regression framework. Respondents that were female, young to middle-aged, lived in urban areas, worked remotely some of the time, and, particularly, primary caregivers of school-age children had the greatest difficulties in fulfilling their job due to household responsibilities.

In addition to household responsibilities affecting the employees' ability to conduct work, work responsibilities also affected household duties. $18.2 \%$ of respondents said their work had affected their ability to take care of their households a lot or more (Figure 46), compared to $28.8 \%$ of firm owners/managers stating the same. On the other hand, 37.7\% of respondents stated that their job was not at all affecting their ability to take care of the household. Female, young to middle-aged workers, and workers taking care of children due to school closures experienced the most difficulties in caring for their household due to job responsibilities (Table 24, Column 2); workers that could work completely remotely had fewer difficulties.

We explore the amount of time spent on domestic/care activities, and how it varied with household characteristics, in the Appendix Section A.IV, Figure A.10, and Table A.3.

Employee Income Sources, Benefits, and Concerns. Information on levels and heterogeneities in employee income sources, benefits, applications for government/NGO assistance, and top concerns can be found in Appendix Section A.IV and Figures A.11, A.12 and A.13.

Working from Home. One of the most significant changes during the current pandemic is the widespread emergence of remote work. Figure 47 shows that $31.9 \%$ of employees reported being able to work remotely all the time, $23.1 \%$ could do so sometimes, and $45.0 \%$ were unable to work 
remotely. Among those who could work remotely at least partially, the most common challenges reported were multi-tasking between work and household responsibilities (28.9\%), the nature of the work $(16.1 \%)$, difficulties in collaborating with others $(11.5 \%)$, a lack of resources $(9.4 \%)$, and household responsibilities (3.6\%).

Figure 48 shows heterogeneities in the main challenge of working from home. Balancing work and home responsibilities was the dominant concern for primary caregivers of children affected by school closures (51.4\%, Panel A) and for respondents that had to take care of a dependent adult (Panel B). Difficulty in collaborating with others was more prevalent among highly educated workers (Panel C), with 15.2\% of employees with a master's degree stating this reason, and $2.4 \%$ of respondents with less than high school education. Women were more likely than men to state multi-tasking between work and household responsibilities was the main concern, and less likely than men to emphasize the nature of their work (Panel D). Similar to previous trends, the age group from 36 to 45 years was particularly occupied with their household duties (Panel E). Finally, limited communication tools were most often mentioned as a concern in rural areas (Panel F).

Employee Information and Outlook. Figure 49 shows that most employees received information about support opportunities during the pandemic from internet news (54.1\%), TV (51.7\%), and social media (49.5\%), which were ranked above government or health authority $(40.2 \%)$.

Finally, we asked workers about their optimism for future employment; $33.6 \%$ of respondents were very optimistic, $29.4 \%$ were somewhat optimistic, $11.8 \%$ stated that they were somewhat pessimistic, and $4.1 \%$ were very pessimistic (Figure 50). Optimism was positively correlated with education; $23.0 \%$ of respondents with no formal education were pessimistic about their future employment compared to only $13.0 \%$ with at least a master's degree. Moreover, young respondents and respondents living in urban areas were less optimistic in our sample.

\section{CONCLUSION}

Small businesses are a key contributor to economic activity in the United States. Yet, we know very little about how these small businesses were affected by the current crisis. This paper presents results from a large-scale survey on the impact of COVID-19 on small business owners, managers, and employees. Our survey was fielded on the Facebook platform in late April 2020 and obtained over 66k responses to 136 questions. Our survey covers respondents across closed and operational businesses, employees and the self-employed, and themes ranging from financial conditions to household responsibilities of businesses owners, managers, and employees.

Our findings highlight the struggles faced by small businesses and their employees, and underscore the need for policy interventions. Going forward, we plan to expand our study to businesses outside the United States. Such a study would help us compare how differences in government responses and orders impacted small businesses in various countries, and provide better evidence for effective policy interventions. We also hope to explore a follow-up survey among U.S. businesses to study how business struggles, expectations, and needs have changed since the beginning of the crisis. Variation in state-level responses within the U.S. could further highlight the trade-off between health and economic outcomes. 


\section{REFERENCES}

Allen, Linda, Lin Peng, and Yu Shan, 2020. Social networks and credit allocation on fintech lending platforms. Available at SSRN.

Alon, Titan, Matthias Doepke, Jane Olmstead-Rumsey, and Michèle Tertilt, 2020a. The Impact of COVID-19 on Gender Equality. Discussion paper, National Bureau of Economic Research.

, 2020b. This Time It's Different: The Role of Women's Employment in a Pandemic Recession. Discussion paper, National Bureau of Economic Research.

Bailey, Michael, Rachel Cao, Theresa Kuchler, and Johannes Stroebel, 2018. The economic effects of social networks: Evidence from the housing market. Journal of Political Economy 126, 2224-2276.

_ , and Arlene Wong, 2018. Social connectedness: Measurements, determinants, and effects. Journal of Economic Perspectives 32, 259-80.

Bailey, Michael, Eduardo Dávila, Theresa Kuchler, and Johannes Stroebel, 2019. House price beliefs and mortgage leverage choice. The Review of Economic Studies 86, 2403-2452.

Bailey, Michael, Patrick Farrell, Theresa Kuchler, and Johannes Stroebel, 2020. Social connectedness in urban areas. Journal of Urban Economics p. 103264.

Bailey, Michael, Abhinav Gupta, Sebastian Hillenbrand, Theresa Kuchler, Robert Richmond, and Johannes Stroebel, 2020. International trade and social connectedness. Working Paper 26960 National Bureau of Economic Research.

Bailey, Michael, Drew Johnston, Theresa Kuchler, Dominic Russel, Bogdan State, and Johannes Stroebel, 2020. The determinants of social connectedness in europe. Social Informatics.

Bali, Turan G, David A Hirshleifer, Lin Peng, and Yi Tang, 2018. Attention, social interaction, and investor attraction to lottery stocks. 9th Miami Behavioral Finance Conference.

Bartik, Alexander W, Marianne Bertrand, Zoe Cullen, Edward L Glaeser, Michael Luca, and Christopher Stanton, 2020. The Impact of COVID-19 on Small Business Outcomes and Expectations. Proceedings of the National Academy of Sciences.

Bartik, Alexander W, Zoe B Cullen, Edward L Glaeser, Michael Luca, and Christopher T Stanton, 2020. What Jobs are Being Done at Home During the COVID-19 Crisis? Evidence from Firm-Level Surveys. Discussion paper, National Bureau of Economic Research.

Bartlett, Morse, 2020. Small Business Survival Capabilities and Policy Effectiveness: Evidence from Oakland. Discussion paper, National Bureau of Economic Research.

Berger, Allen, and Gregory Udell, 1998. The Economics of Small Business Finance: The Roles of Private Equity and Debt Markets in the Financial Growth Cycle. Journal of Banking \& Finance 22, 613 - 673.

Buffington, Catherine, Carrie Dennis, Emin Dinlersoz, Lucia Foster, and Shawn Klimek, 2020. Measuring the effect of covid-19 on us small businesses: The small business pulse survey. Discussion paper, .

Campello, Murillo, Gaurav Kankanhalli, and Pradeep Muthukrishnan, 2020. Corporate Hiring under COVID-19: Labor Market Concentration, Downskilling, and Income Inequality. Discussion paper, National Bureau of Economic Research. 
Carlson, Daniel L, Richard Petts, and Joanna Pepin, 2020. US Couples' Divisions of Housework and Childcare During COVID-19 Pandemic. Discussion paper, SocArXiv.

Coibion, Olivier, Yuriy Gorodnichenko, and Michael Weber, 2020. How Did US Consumers Use Their Stimulus Payments? Discussion paper, National Bureau of Economic Research.

Cox, Natalie, Peter Ganong, Pascal Noel, Joseph Vavra, Arlene Wong, Diana Farrell, and Fiona Greig, 2020. Initial Impacts of the Pandemic on Consumer Behavior: Evidence from Linked Income, Spending, and Savings Data. University of Chicago, Becker Friedman Institute for Economics Working Paper.

Dingel, Jonathan I, and Brent Neiman, 2020. How Many Jobs can be Done at Home?. Discussion paper, National Bureau of Economic Research.

Fairlie, Robert W, 2020. The Impact of COVID-19 on Small Business Owners: Continued Losses and the Partial Rebound in May 2020. Discussion paper, National Bureau of Economic Research.

Giglio, Stefano, Matteo Maggiori, Johannes Stroebel, and Stephen Utkus, 2020. Inside the Mind of a Stock Market Crash. Discussion paper, National Bureau of Economic Research.

Gopal, Manasa, and Philipp Schnabl, 2020. The Rise of Finance Companies and FinTech Lenders in Small Business Lending. Working Paper.

Humphries, John Eric, Christopher Neilson, and Gabriel Ulyssea, 2020. The Evolving Impacts of COVID-19 on Small Businesses Since the CARES Act. Cowles Foundation Discussion Paper.

Kim, Ryan, 2020. The Effect of the Credit Crunch on Ouput Price Dynamics: The Corporate Inventory and Liquidity Management Channel. Quarterly Journal of Economics.

Kuchler, Theresa, Lin Peng, Johannes Stroebel, Yan Li, and Dexin Zhou, 2020. Social proximity to capital: Implications for investors and firms. Discussion paper, Working paper.

Kuchler, Theresa, Dominic Russel, and Johannes Stroebel, 2020a. The geographic spread of covid-19 correlates with structure of social networks as measured by facebook. Working Paper 26990 National Bureau of Economic Research.

— , 2020b. The Geographic Spread of COVID-19 Correlates with Structure of Social Networks as Measured by Facebook. Discussion paper, National Bureau of Economic Research.

Mach, Traci, 2007. Survey of Small Business Finances: Presentation. Working Paper.

Perrin, Andrew, and Monica Anderson, 2019. Share of u.s. adults using social media, including facebook, is mostly unchanged since 2018. Pew Research Center.

Rehbein, Oliver, and Simon Rother, 2020. Distance in bank lending: The role of social networks. Discussion paper, University of Bonn and University of Mannheim, Germany.

Sufi, Amir, 2007. Bank Lines of Credit in Corporate Finance: An Empirical Analysis. The Review of Financial Studies 22, 1057-1088.

Wilson, Riley, 2019. The impact of social networks on eitc claiming behavior. Brigham Young University, Department of Economics. 


\section{FIGURES}

Figure 1: Flowchart of Core Survey Paths. This figure provides a broad overview of the path users could take through the survey. Numbers in parentheses refer to the number of people who responded to either the first or last question in the corresponding section. For example, 97,152 people answered the business role question, 15,435 responded in a way that indicates they were employees, and 9,837 people answered the last question of the employee module. Finally, the Business Employment section was only given to firms with more than one employee, since its aim was to ask about employment outcomes, causing the lower number. The drop off rate is large but within the bounds of what is expected given the survey length and platform.

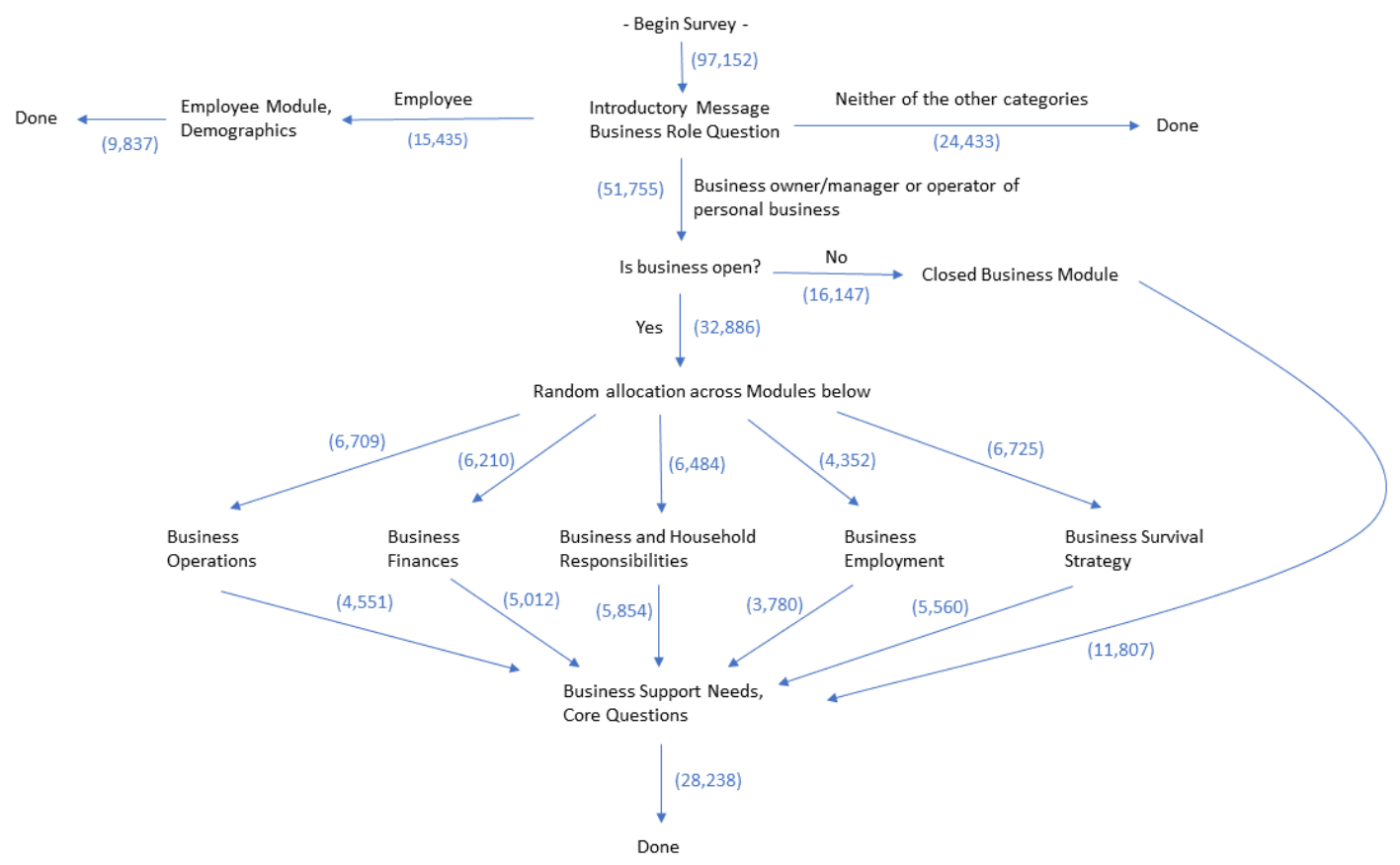


Figure 2: Basic Business Information

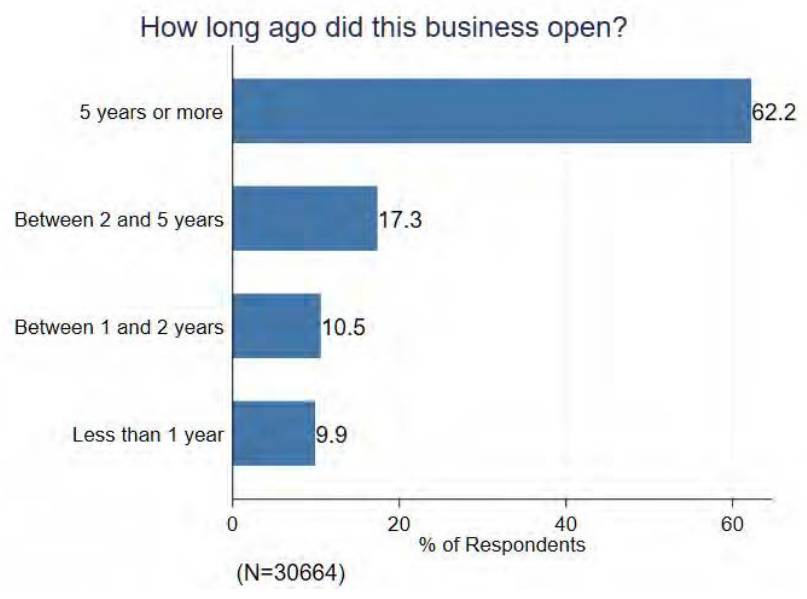

(A) Firm Age Distribution

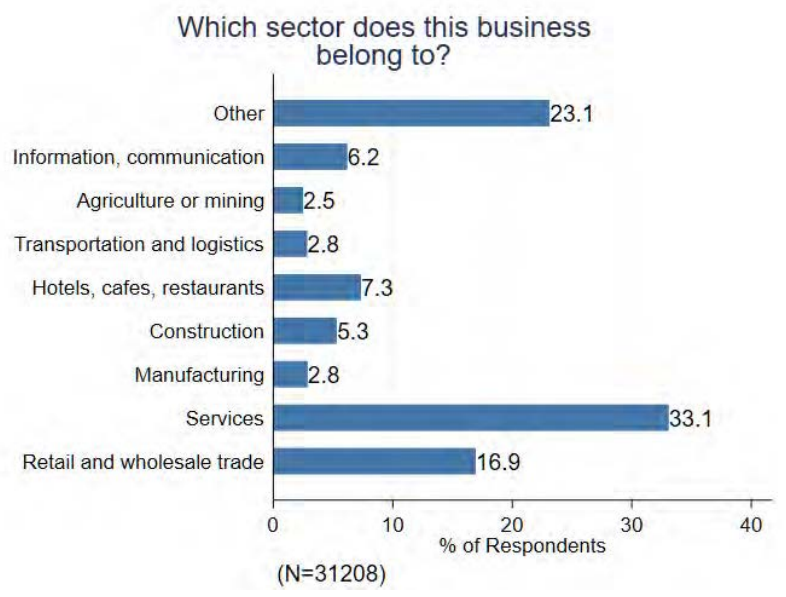

(C) Firm Sectoral Distribution

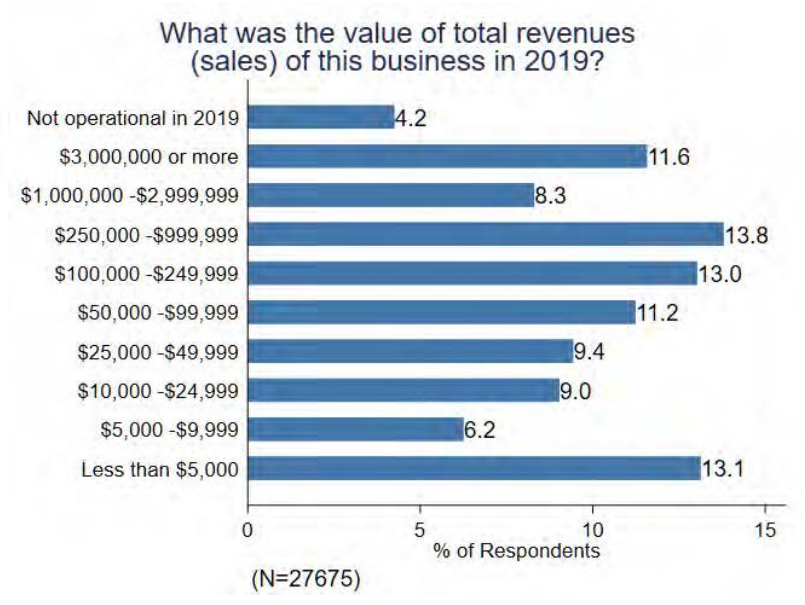

(B) Firm Sales Distribution

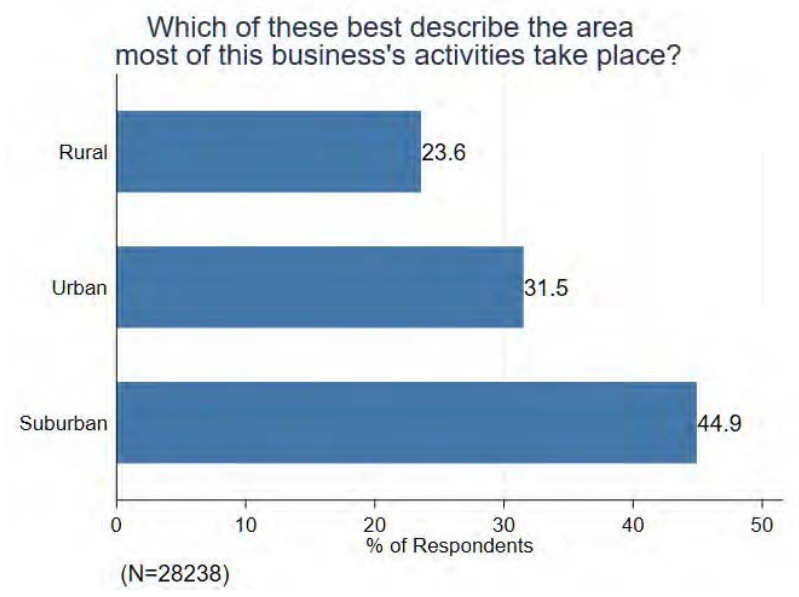

(D) Firm Location 


\section{Figure 3: Business Employees}

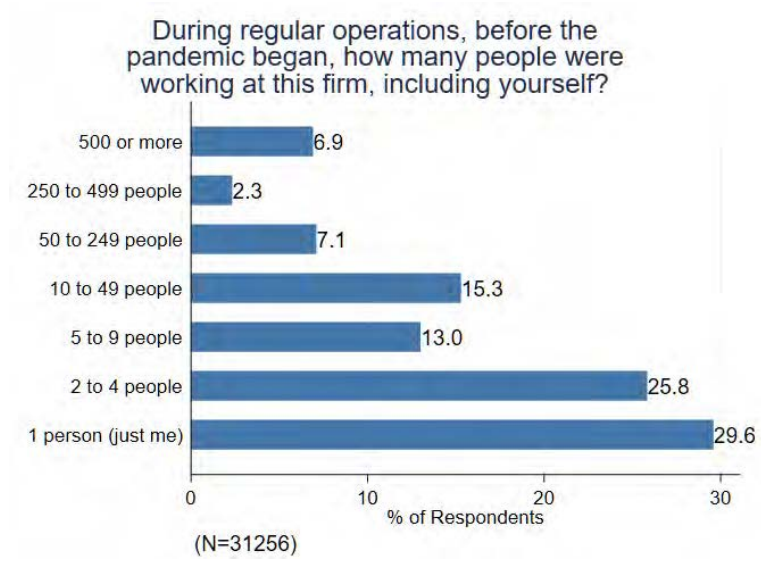

(A) Firm Employment

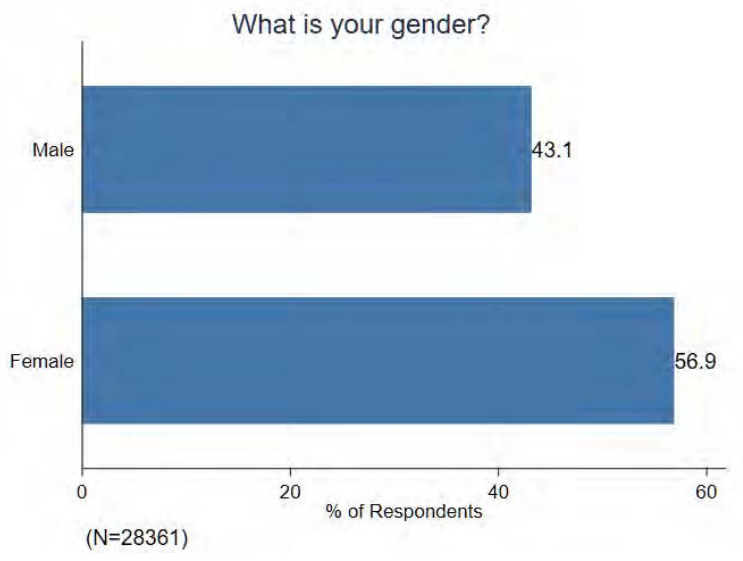

(B) Firm Owner Gender

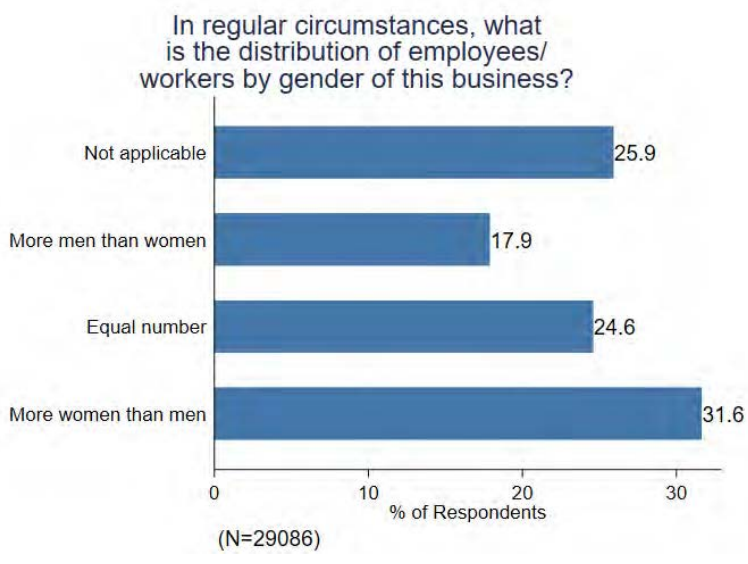

(C) Firm Gender Balance

Figure 4: Business Operations

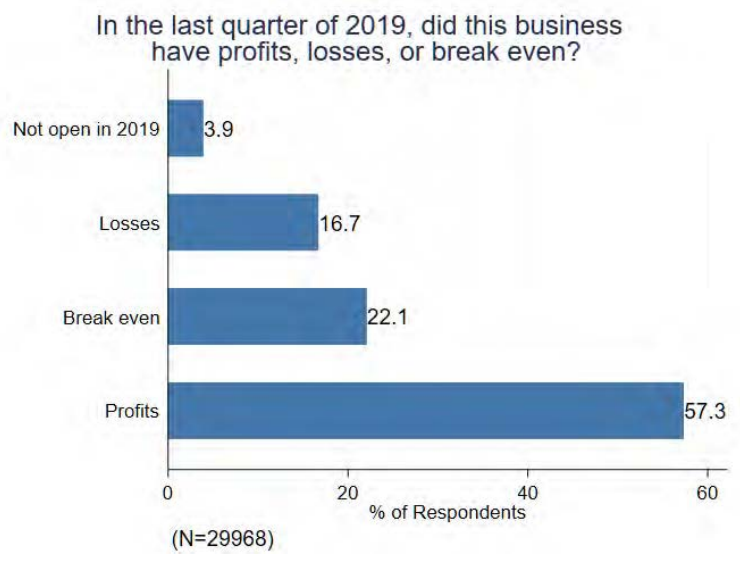

(A) Firm Profits

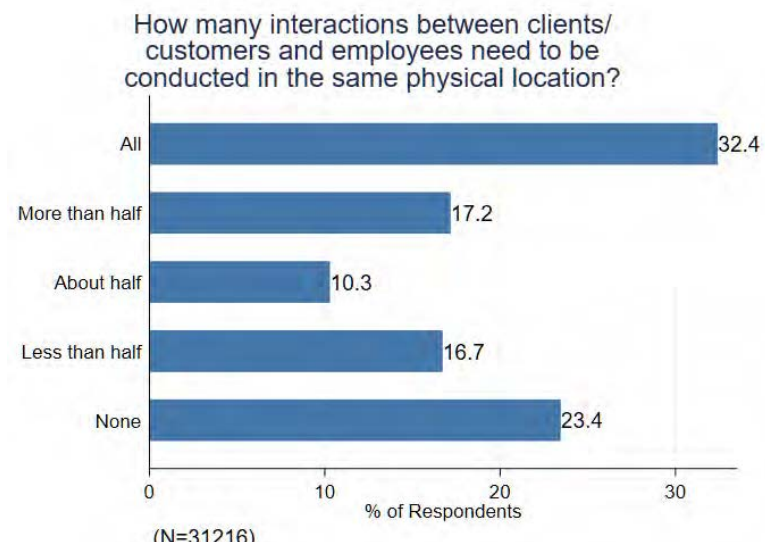

$(\mathrm{N}=31216)$

(B) Firm In-Person Operations 


\section{Figure 5: Business Closure}

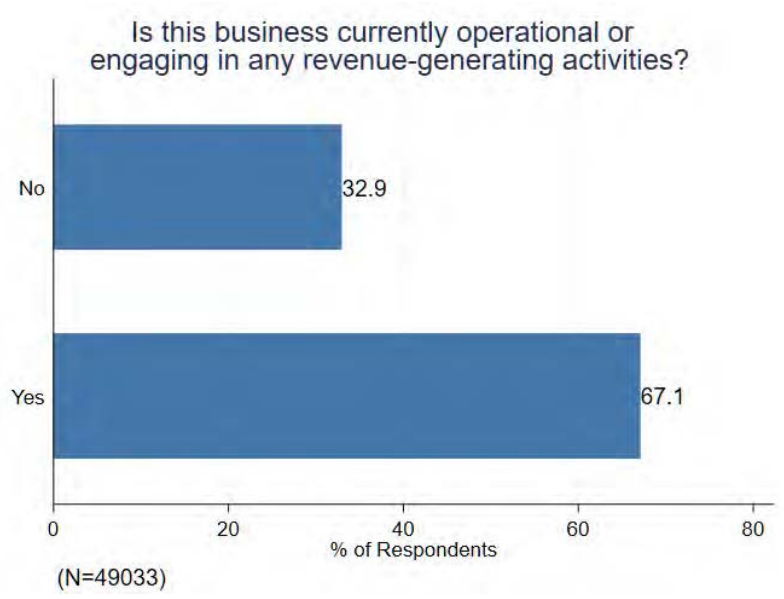

(A) Firm Currently Operational

Is this business currently operational or engaging in any revenue-generating activities?

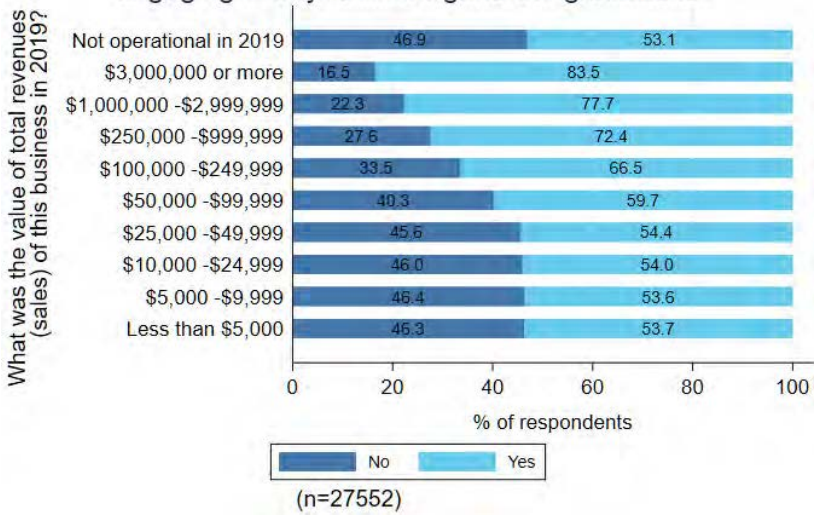

(C) Business Closure, by Firm Sales

Is this business currently operational or engaging in any revenue-generating activities?

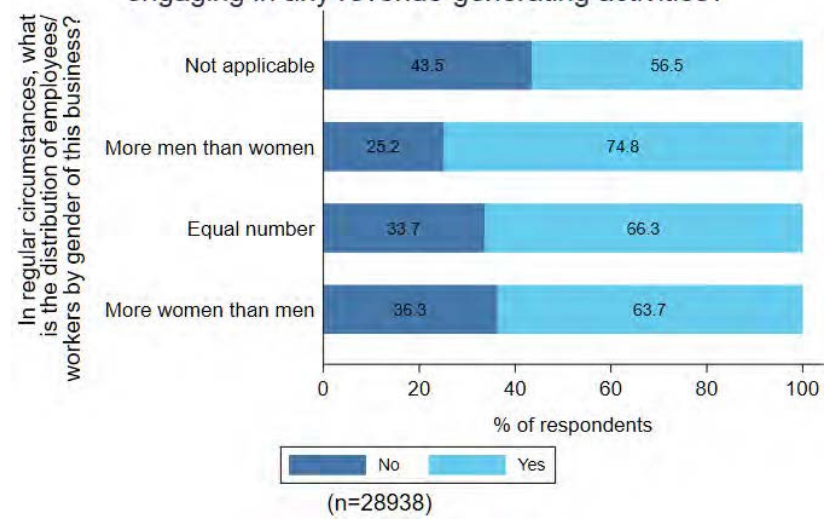

(E) Business Closure, by Firm Gender Balance
Is this business currently operational or engaging in any revenue-generating activities?

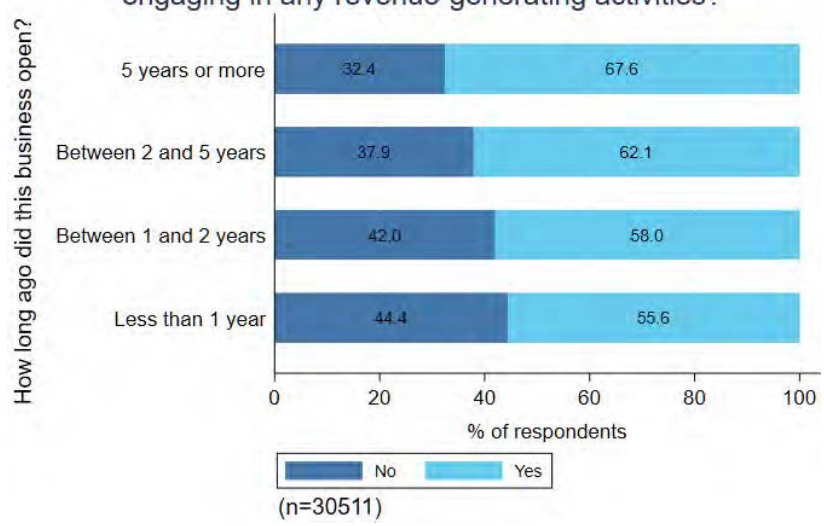

(B) Business Closure, by Firm Age

Is this business currently operational or engaging in any revenue-generating activities?

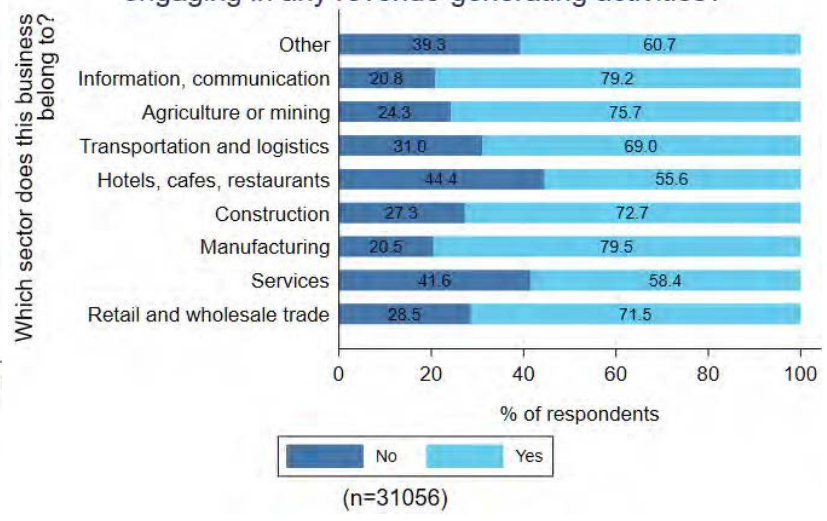

(D) Business Closure, by Firm Sector

Is this business currently operational or engaging in any revenue-generating activities?

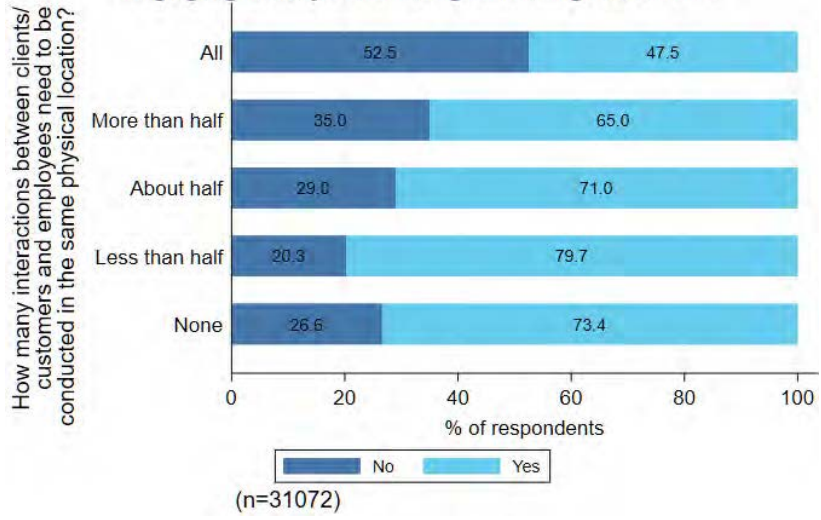

(F) Business Closure, by In-person Operations 


\section{Figure 6: Future Expectations}

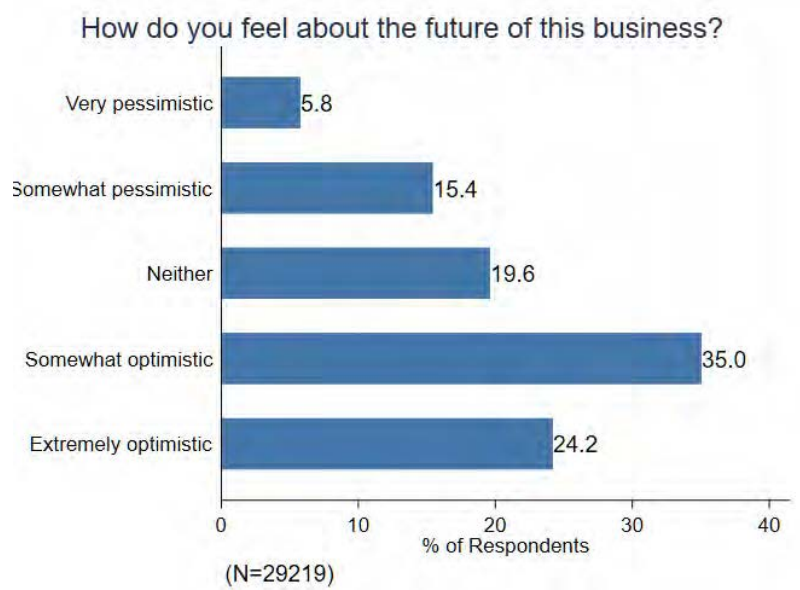

(A) Future Expectations

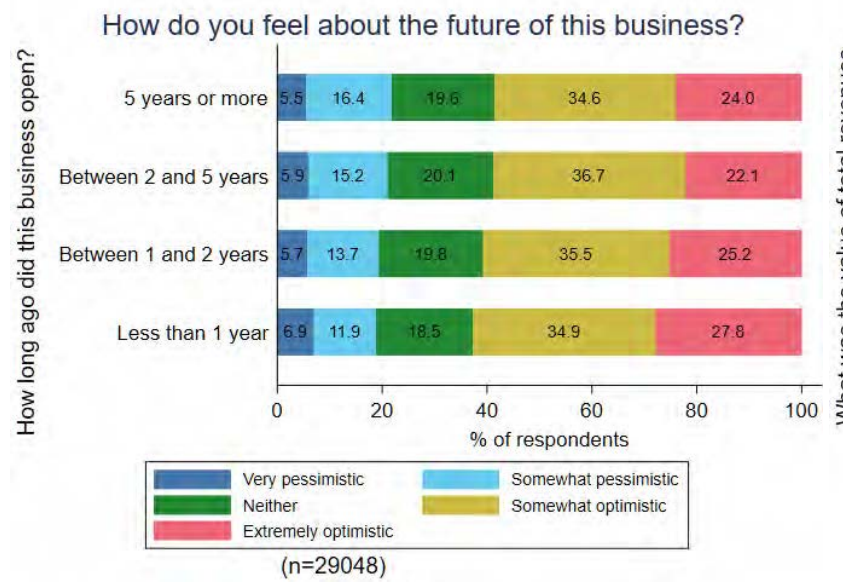

(C) Future Expectations, by Firm Age

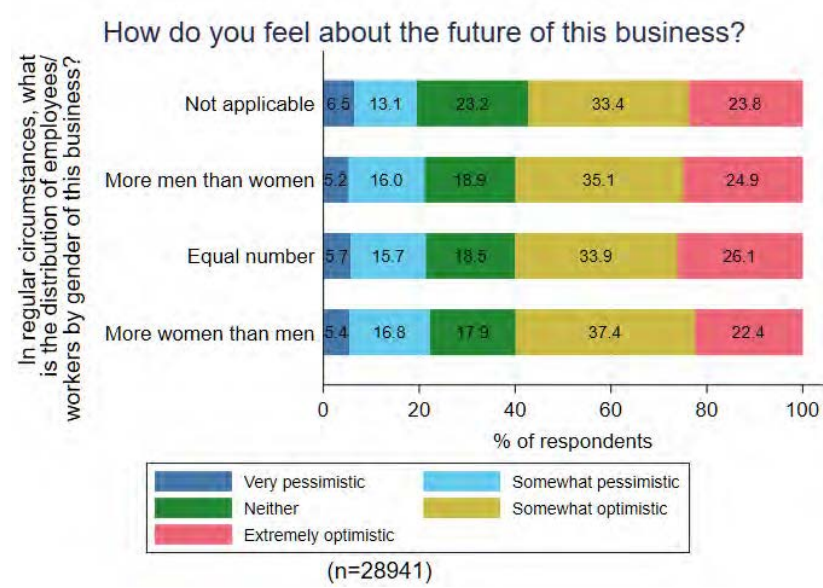

(E) Future Expectations, by Firm Gender Balance
How do you feel about the future of this business?

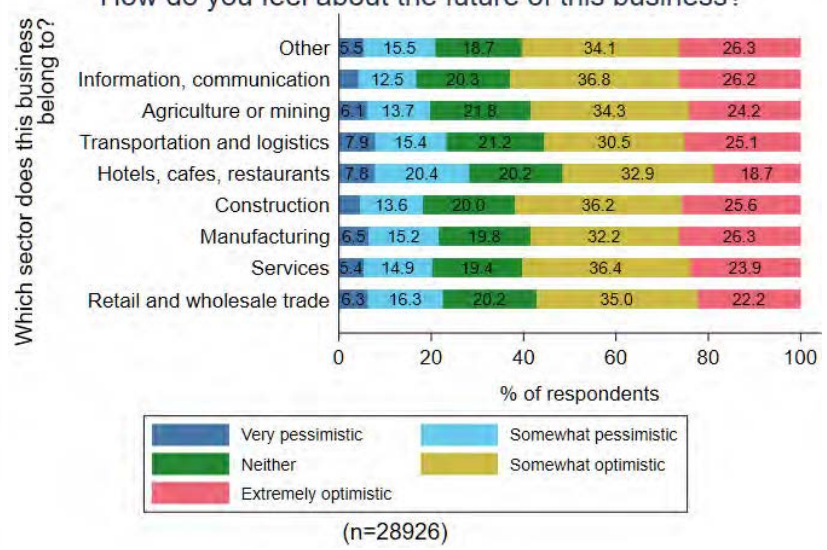

(B) Future Expectations, by Firm Sector

How do you feel about the future of this business?

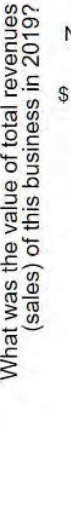

\begin{tabular}{|l|l|l|l|l|l|l|} 
Not operational in 2019 & 6.71 .2 & 18.8 & 34.3 & 28.9 \\
\hline
\end{tabular}

\begin{tabular}{|l|l|l|l|l|}
$\$$ & $\$ 3,000,000$ or more & 13.2 & 32.5 & 34.8 \\
\hline
\end{tabular}

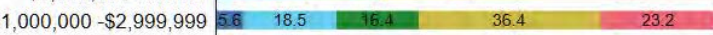

$\begin{array}{lllllll}\$ 250,000 & -\$ 999,999 & 5.5 & 19.3 & 18.2 & 36.2 & 20.8\end{array}$

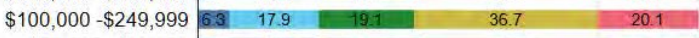

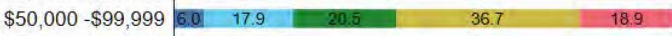

\begin{tabular}{|l|ll|ll|l|l|}
$\$ 25,000$ & $\$ 49,999$ & 6.2 & 15.9 & 211 & 36.4 & 20.4
\end{tabular}

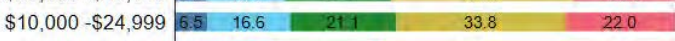

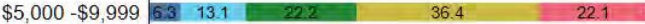

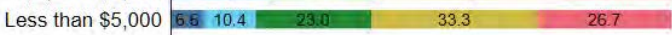

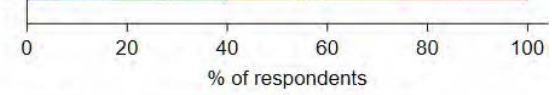

\begin{tabular}{|l|l|}
\hline Very pessimistic & Somewhat pessimistic \\
Neither & Somewhat optimistic \\
Extremely optimistic & \\
\hline
\end{tabular}

$(n=27081)$

(D) Future Expectations, by Firm Sales

How do you feel about the future of this business?

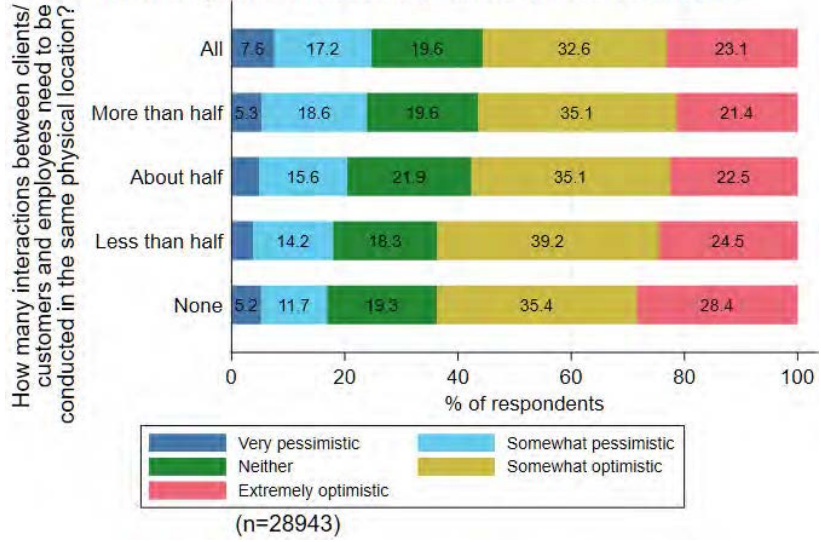

(F) Future Expectations, by Firm In-Person Operations 


\section{Figure 7: Business Challenges}

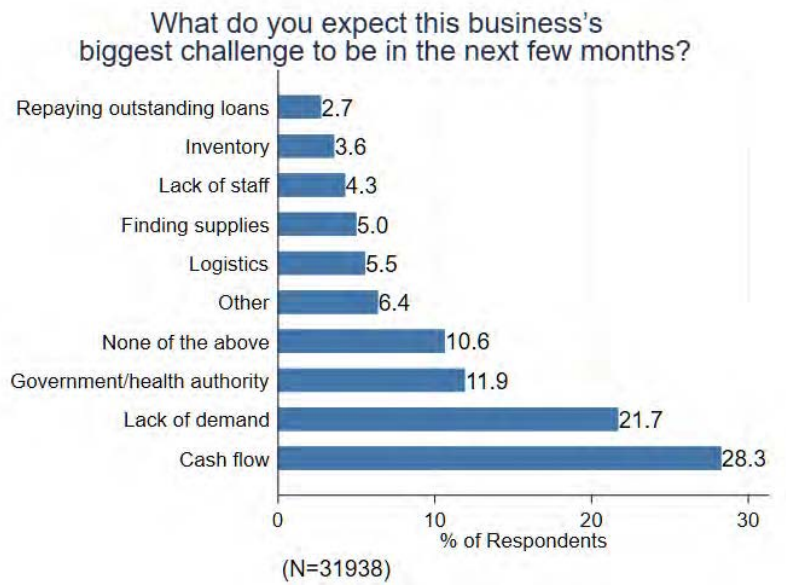

\section{Figure 8: Business Workload During COVID-19}

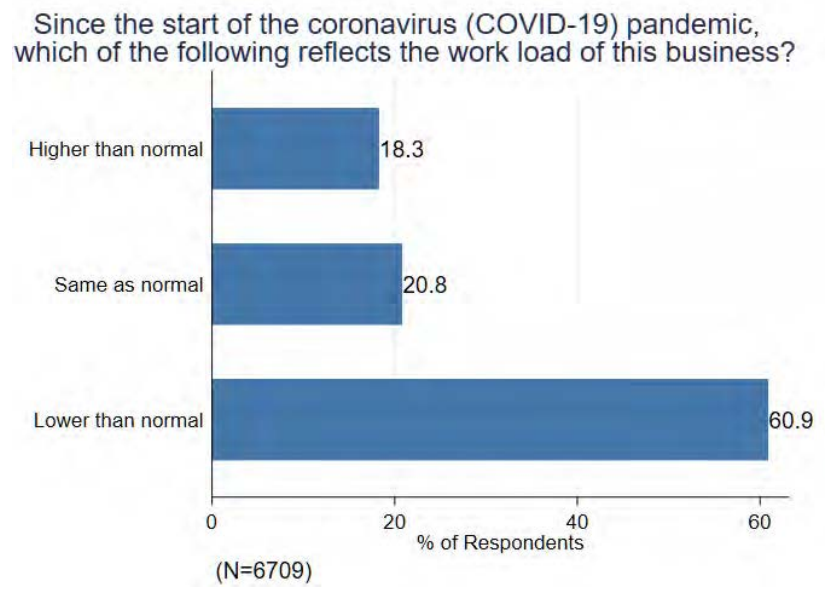

(A) Business Workload

What was the main reason

there has been a lower than normal work load?

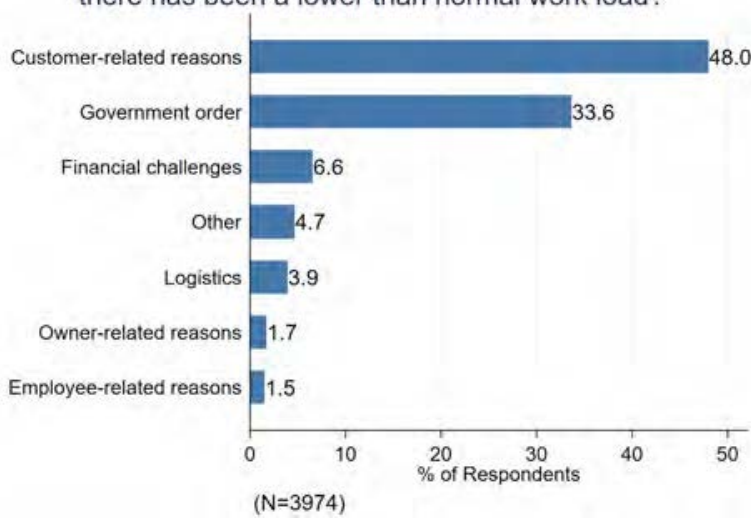

(B) Reason for Lower Workload

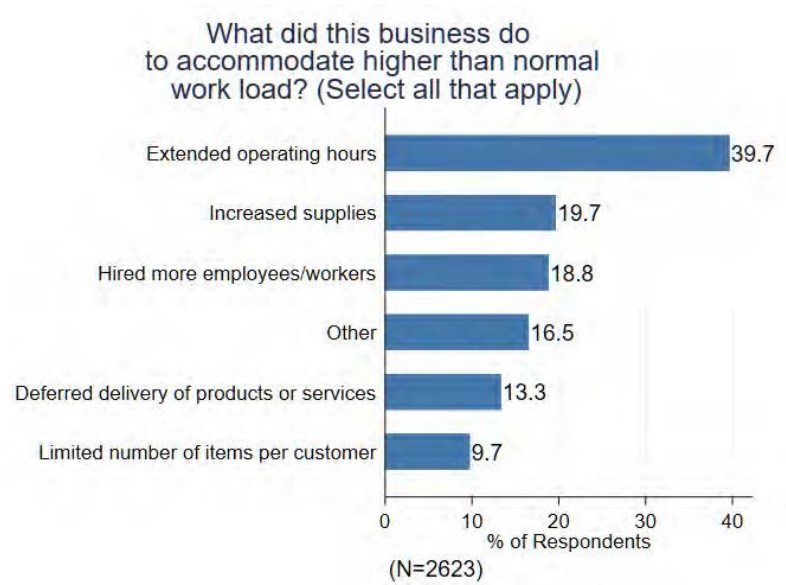

(C) Accommodation for Higher Workload 


\section{Figure 9: Workload Crosstabs}

Since the start of the coronavirus (COVID-19) pandemic which of the following reflects the work load of this business?
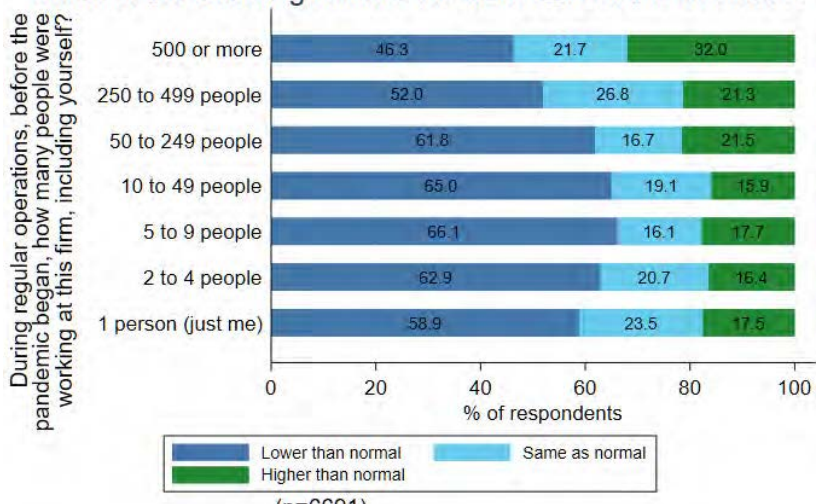

(A) Workload, by Business Employment

Since the start of the coronavirus (COVID-19) pandemic which of the following reflects the work load of this business?

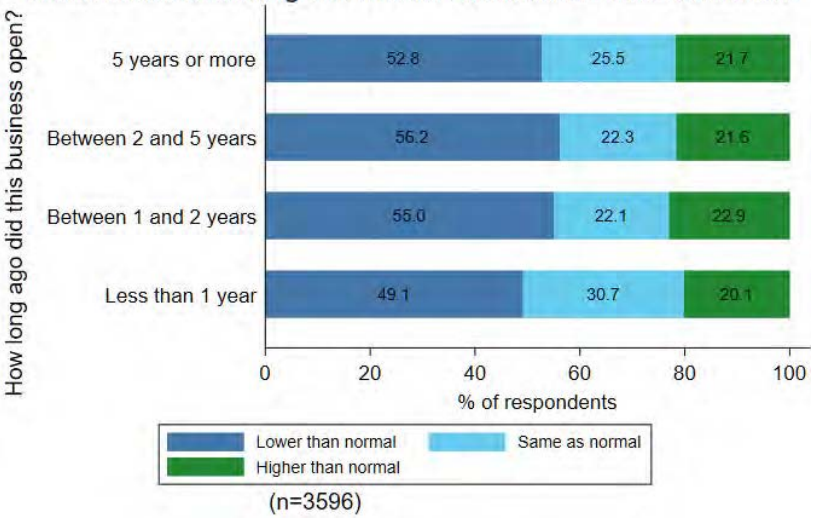

(C) Workload, by Business Age

Since the start of the coronavirus (COVID-19) pandemic which of the following reflects the work load of this business?

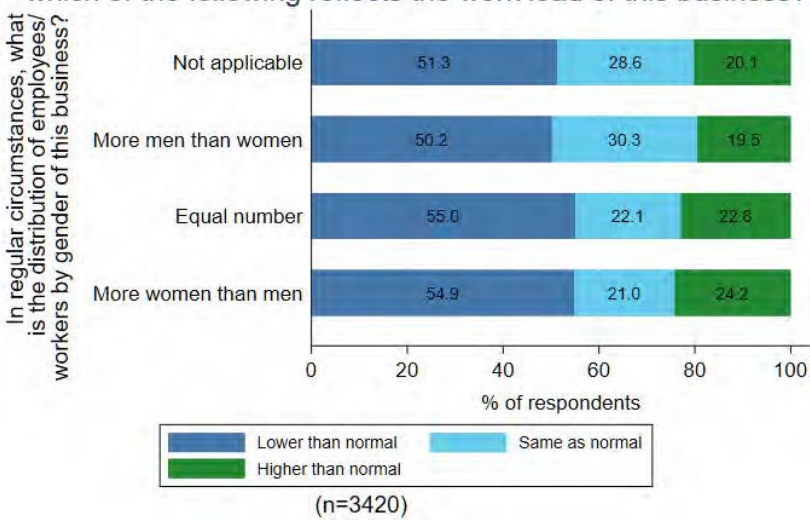

(E) Workload, by Business Gender Balance
Since the start of the coronavirus (COVID-19) pandemic which of the following reflects the work load of this business?

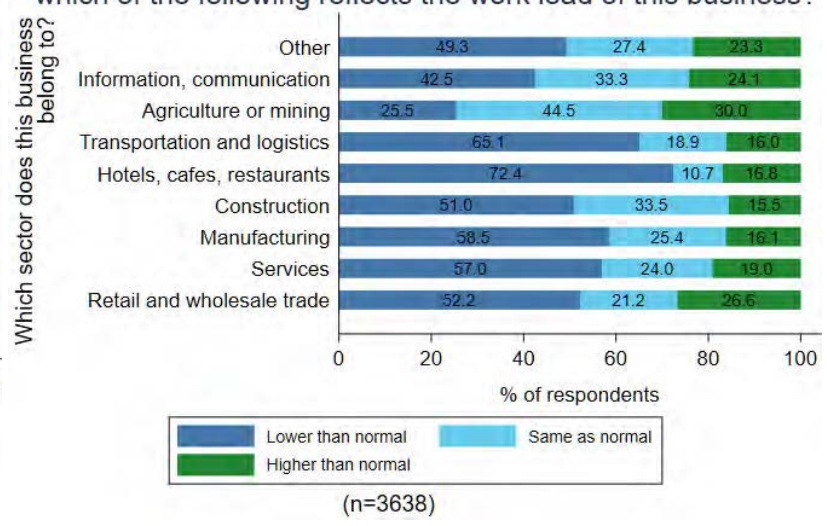

(B) Workload, by Business Sector

Since the start of the coronavirus (COVID-19) pandemic, which of the following reflects the work load of this business?

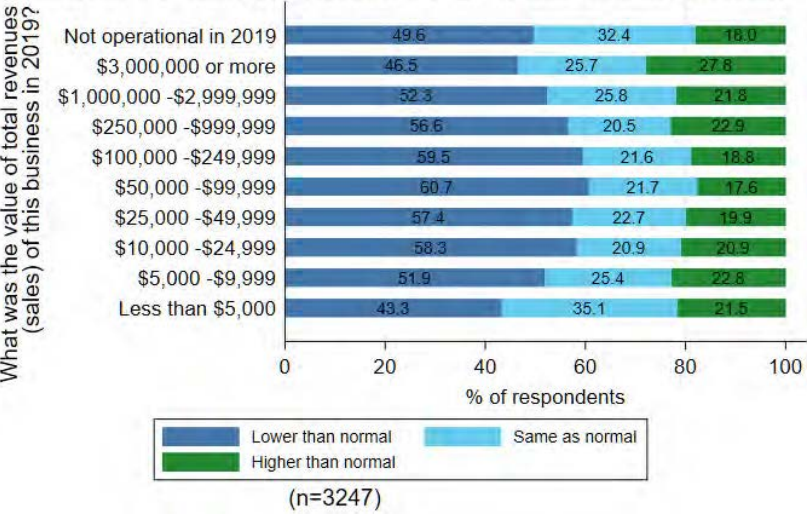

(D) Workload, by Business Sales

Since the start of the coronavirus (COVID-19) pandemic, which of the following reflects the work load of this business?

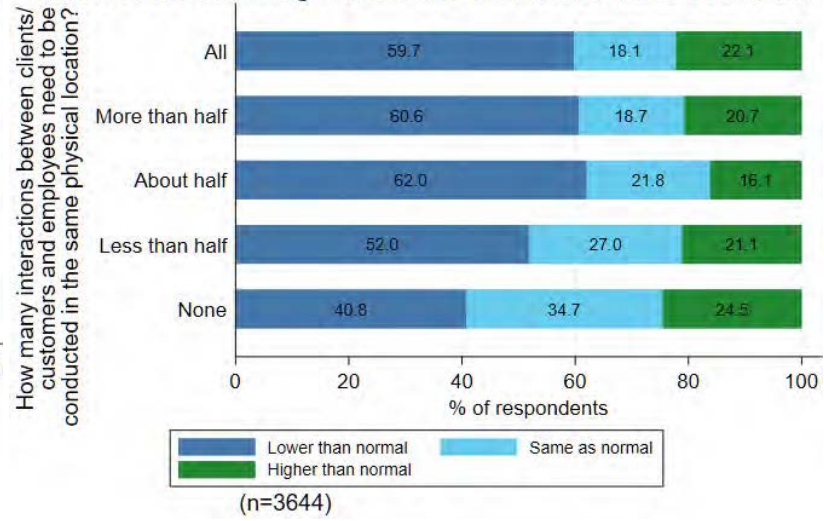

(F) Workload, by Business In-Person Operations 


\section{Figure 10: Change in Business Sales During COVID-19}

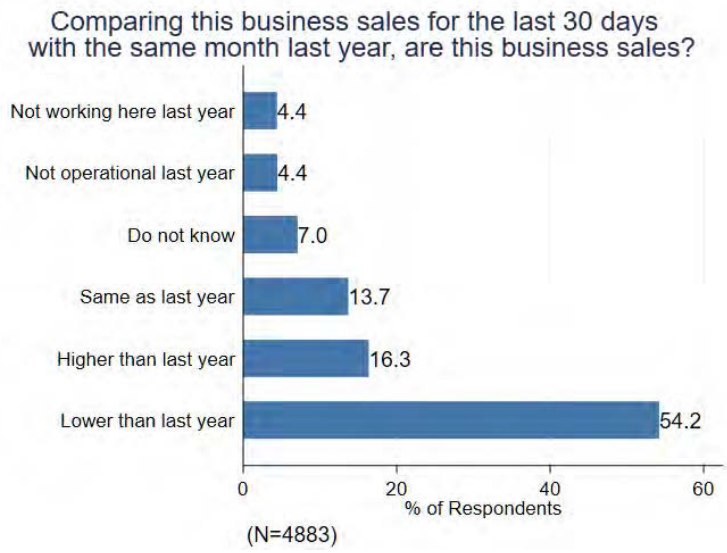

(A) Business Sales

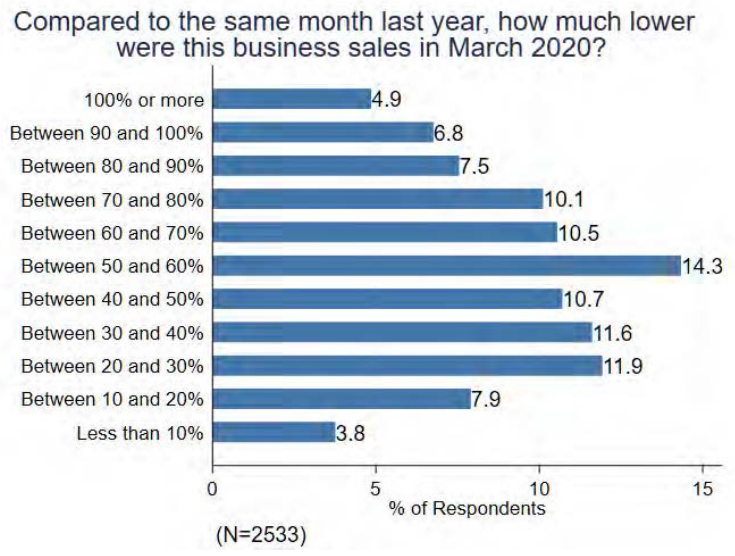

(B) Business Sales Drop
Compared to the same month last year, how much higher were this business sales in March 2020?

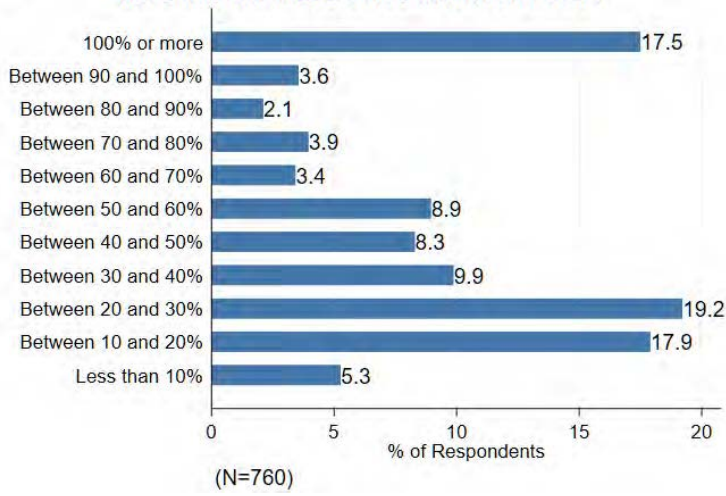

(C) Business Sales Growth

\section{Figure 11: Business Survival}

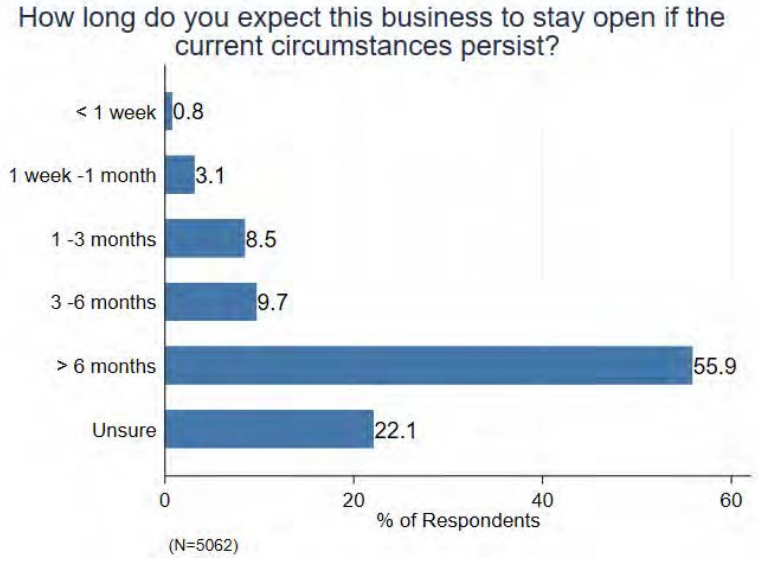

(A) Business Persistence
Which of the following would most help this business adapt the coronavirus (COVID-19) pandemic? (Select all that apply)

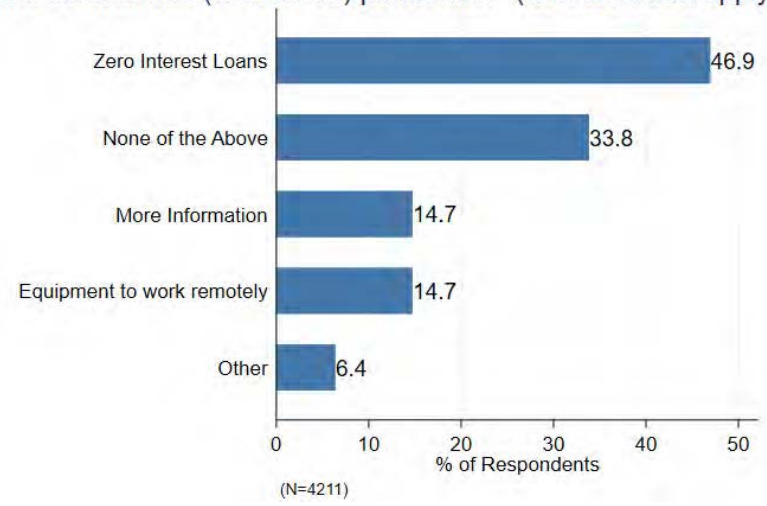

(B) Business Requirements 


\section{Figure 12: Survival Expectations Crosstabs}

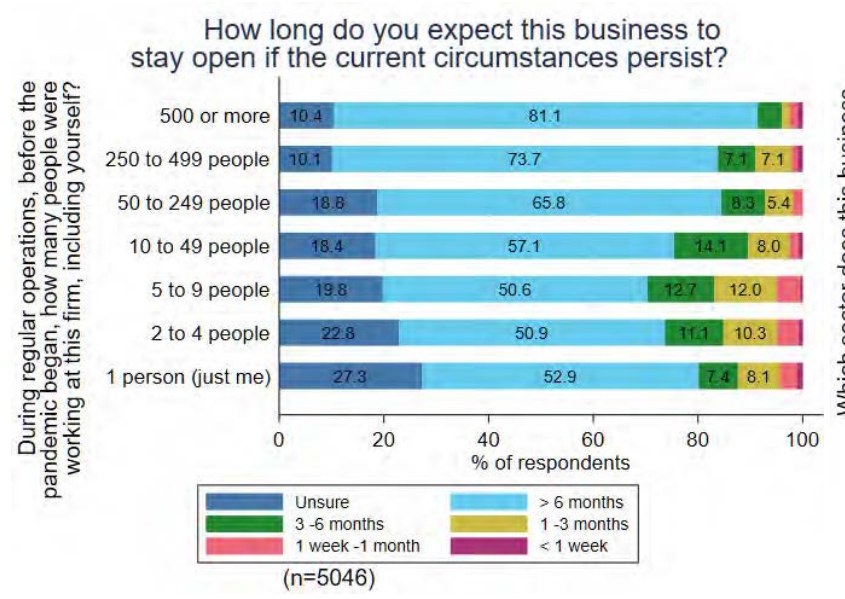

(A) Business Survival, by Business Employment

How long do you expect this business to stay open if the current circumstances persist?

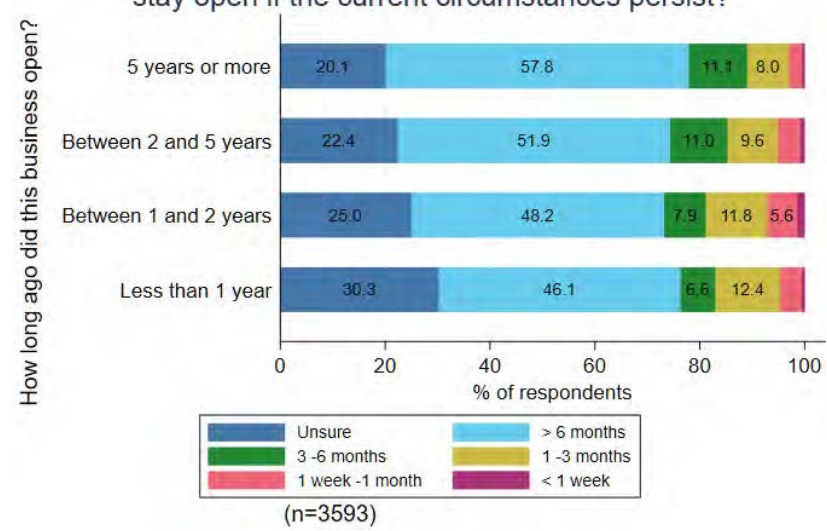

(C) Business Survival, by Business Age

How long do you expect this business to stay open if the current circumstances persist?

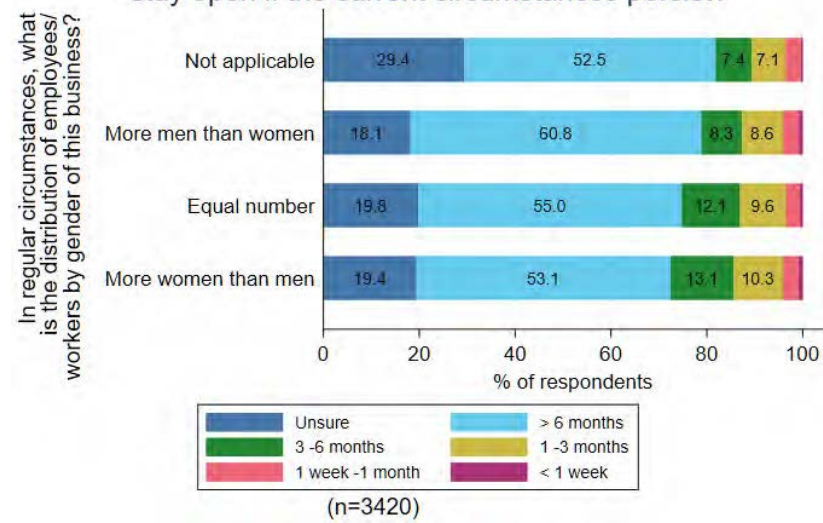

(E) Business Survival, by Business Gender

Balance
How long do you expect this business to stay open if the current circumstances persist?

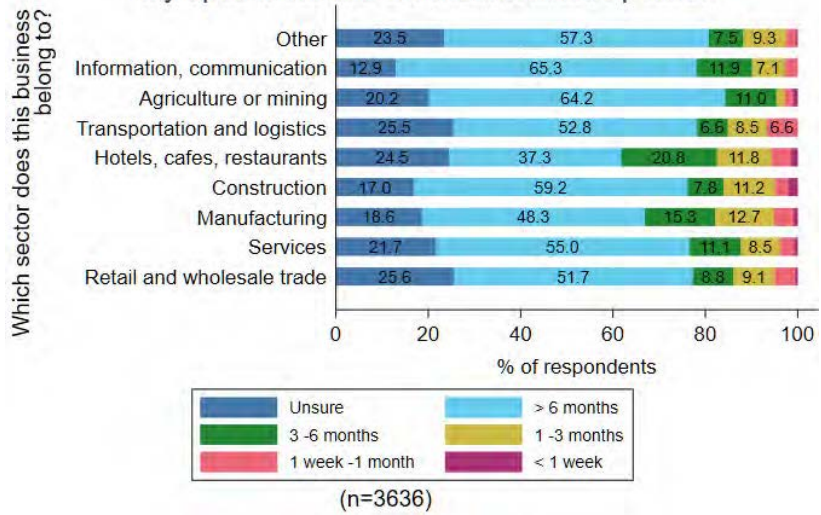

(B) Business Survival, by Business Sector

How long do you expect this business to stay open if the current circumstances persist?

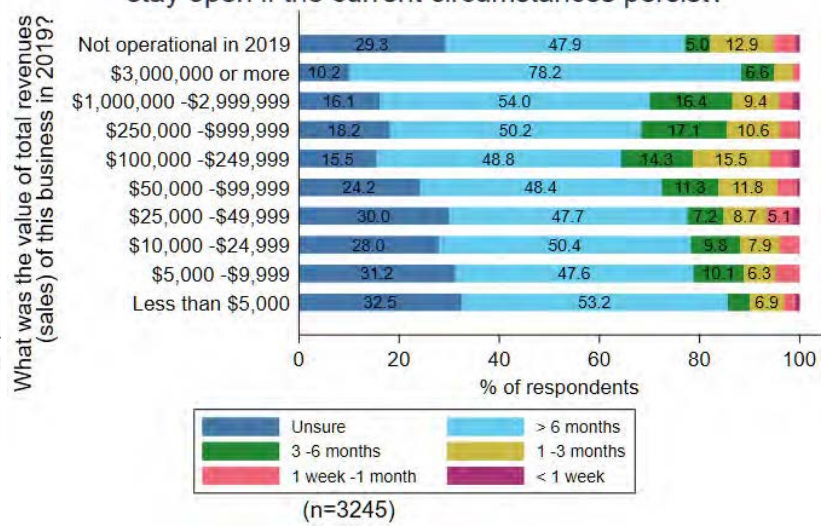

(D) Business Survival, by Business Sales

How long do you expect this business to stay open if the current circumstances persist?

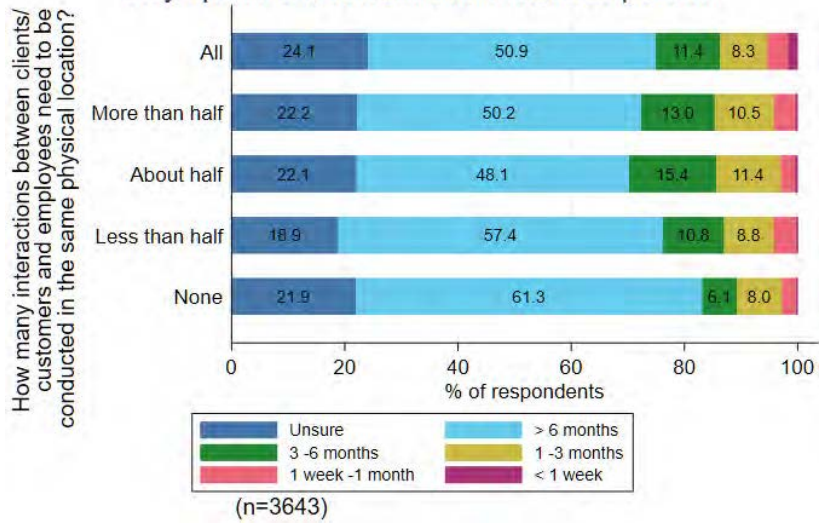

(F) Business Survival, by Business In-person Operations 


\section{Figure 13: Business Supply Challenges}

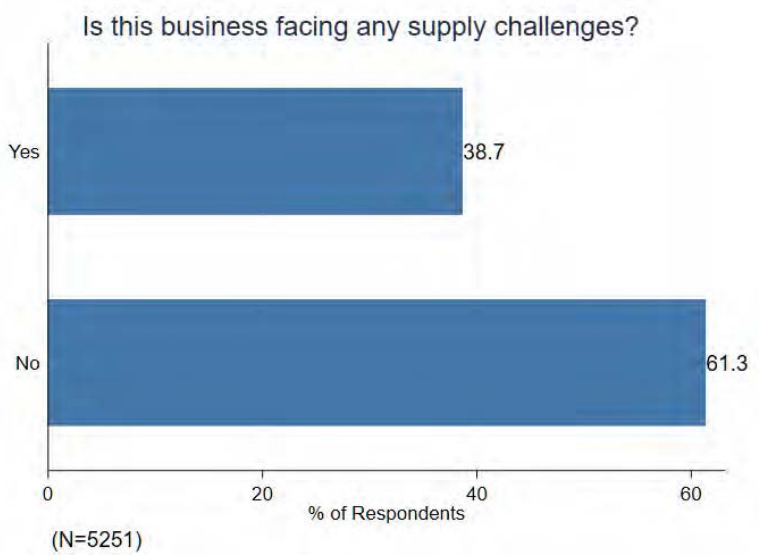

(A) Business Supply Challenges
Which of the following supply challenges

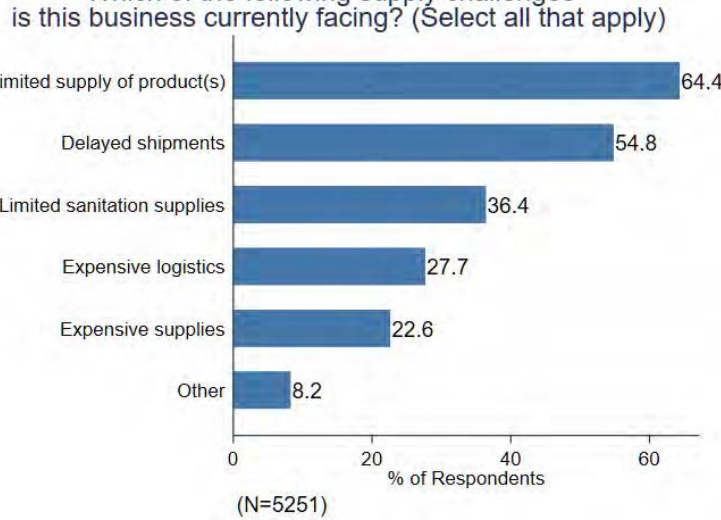

(B) Types of Business Supply Challenges

Figure 14: Virus Containment and Operational Responses

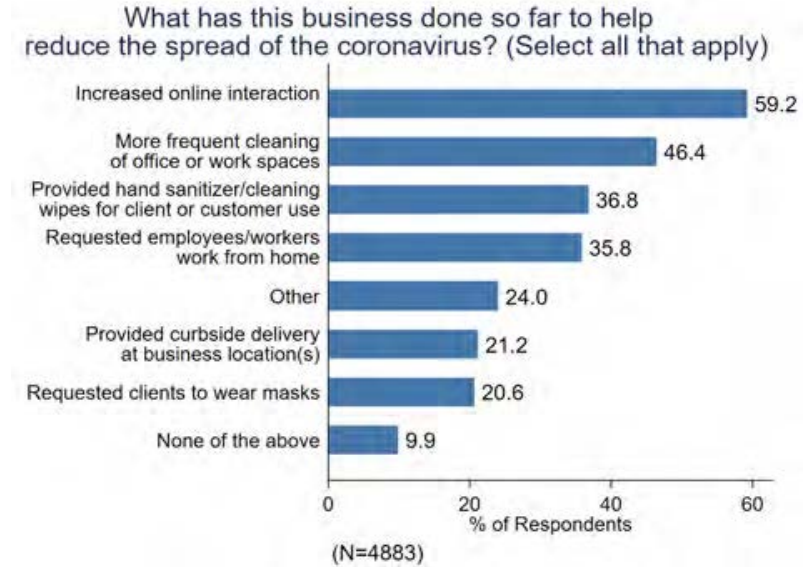

(A) Business Actions

Did this business change anything compared to standard business operations due to the pandemic?

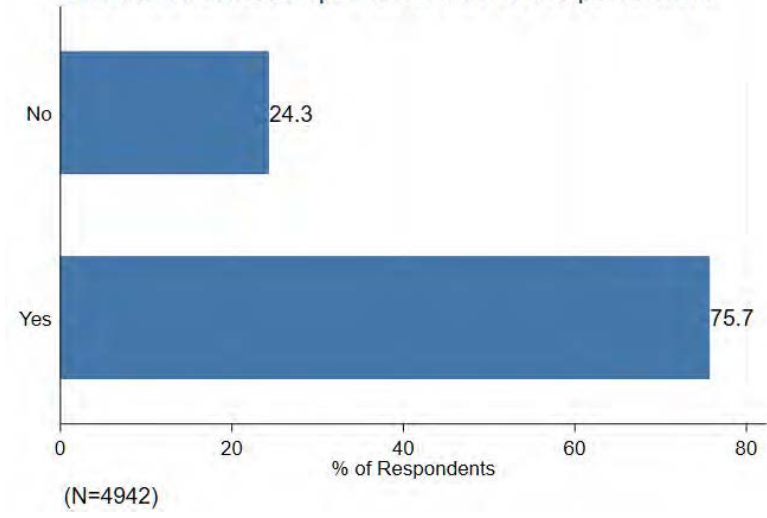

(B) Business Changes

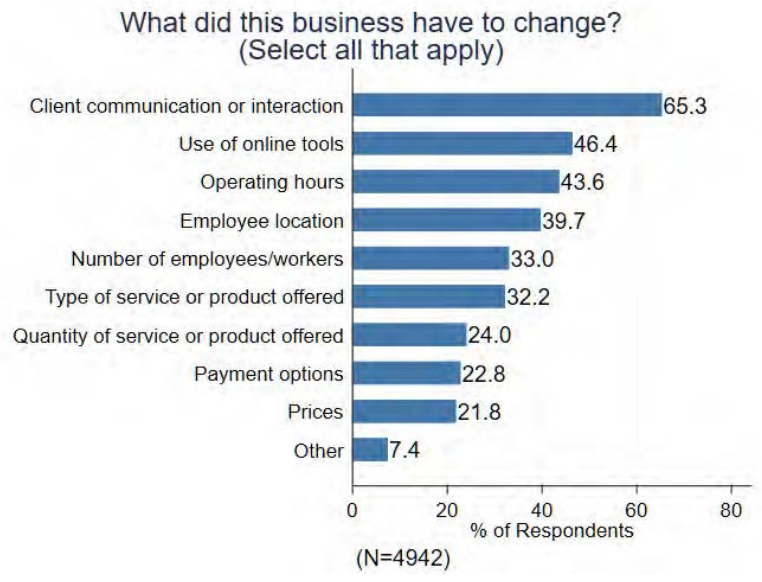

(C) Types of Changes 


\section{Figure 15: Business Financial Struggles}

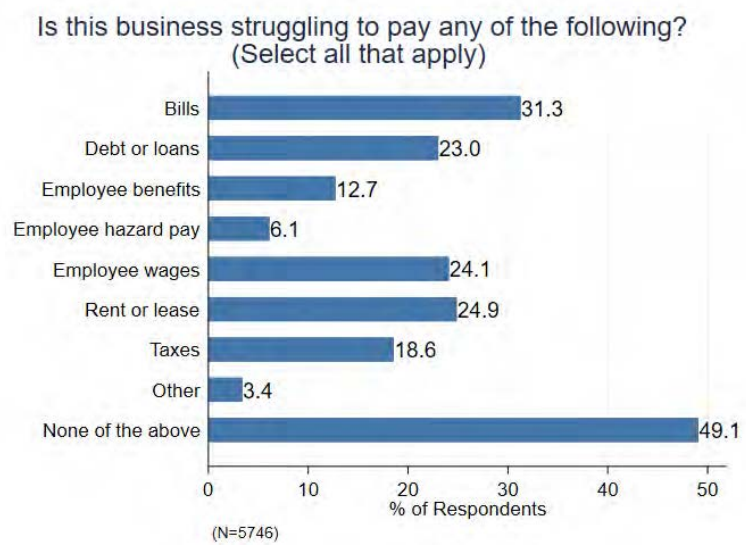

Figure 16: Business Bank Loan

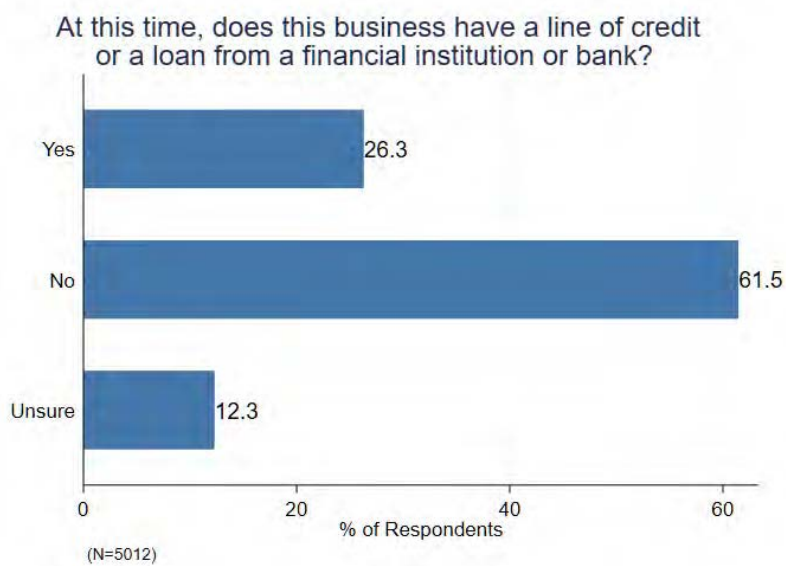

(A) Business Bank Loans

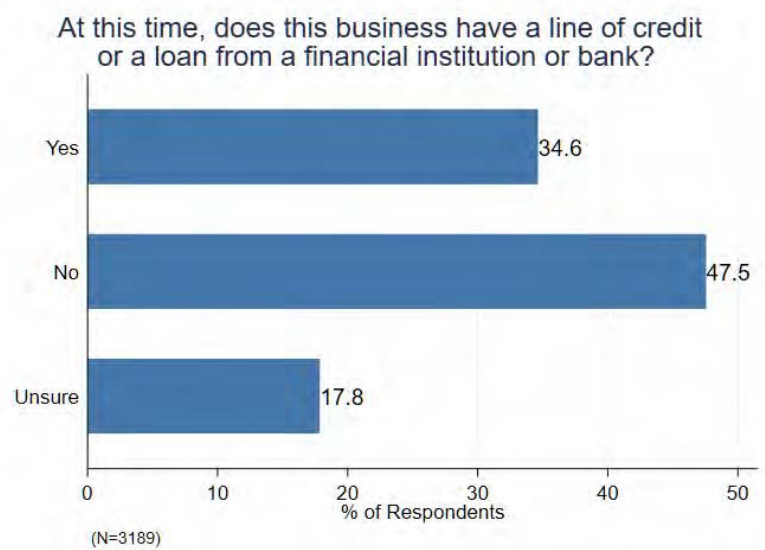

(B) Business Bank Loans, Employer Firms Only

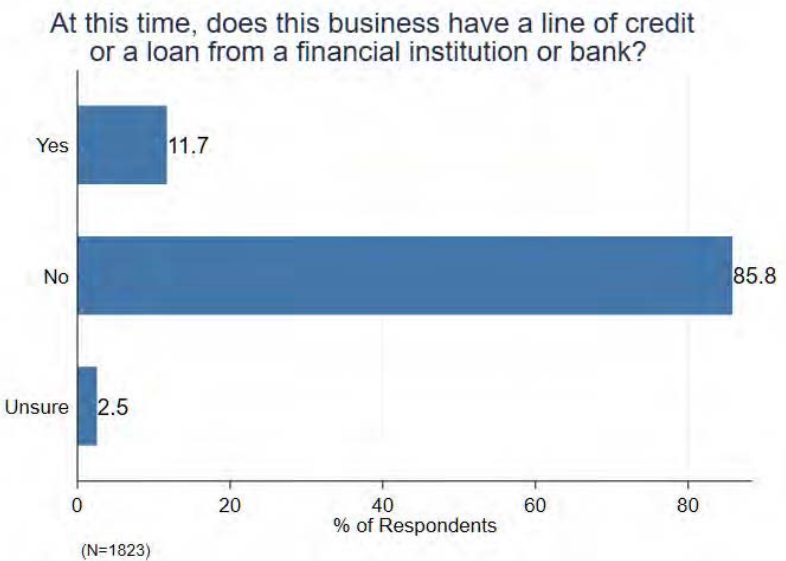

(C) Business Bank Loans, Non-Employer Firms Only 


\section{Figure 17: Formal Sources of Business Capital}

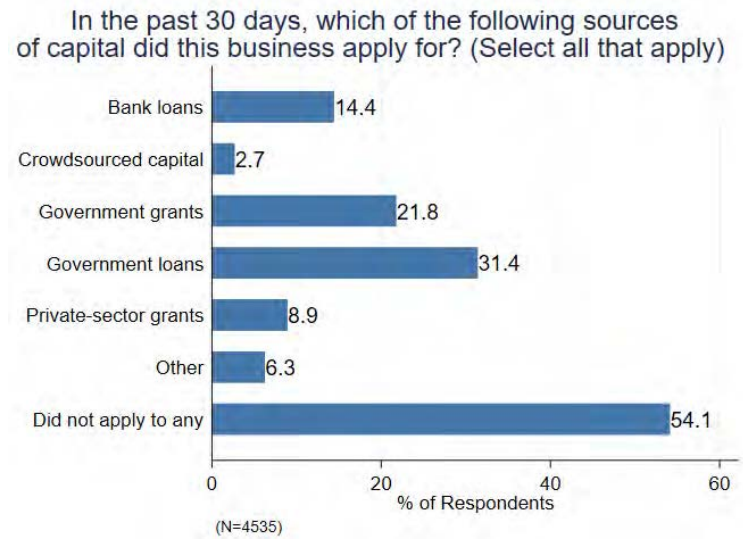

(A) Formal Sources of Business Capital

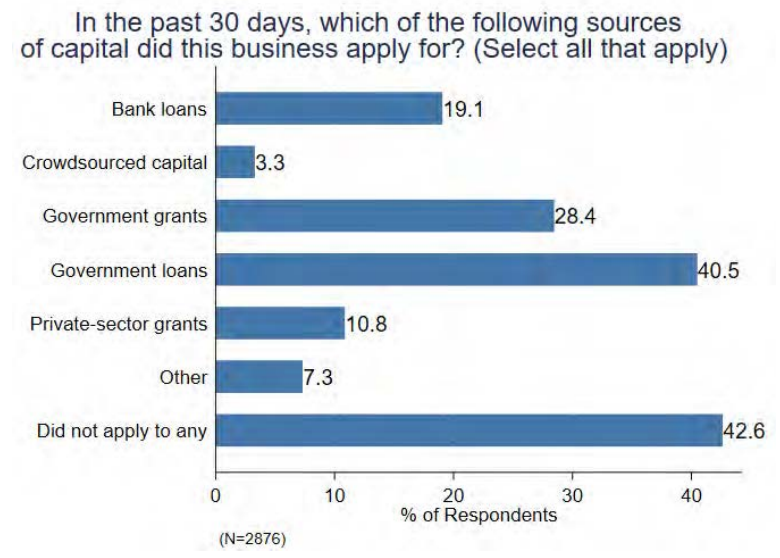

(B) Formal Sources of Business Capital, Employer Firms Only

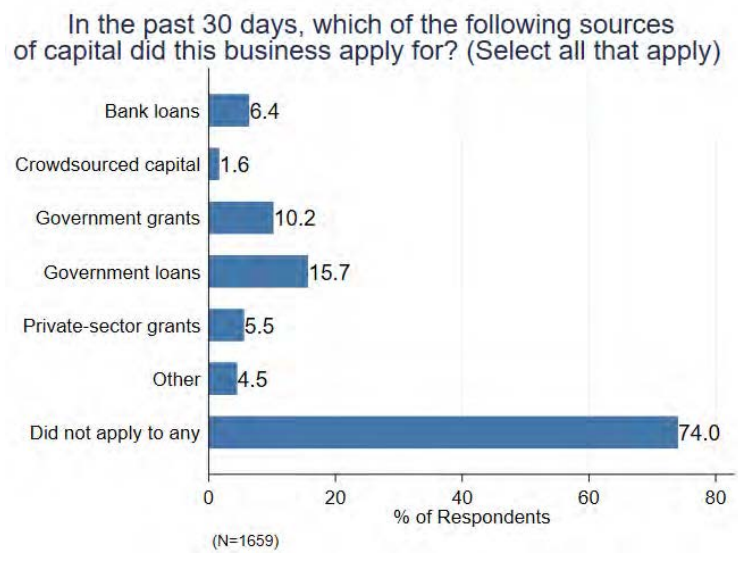

(C) Formal Sources of Business Capital, Non-Employer Firms Only 


\section{Figure 18: Informal Sources of Business Capital}

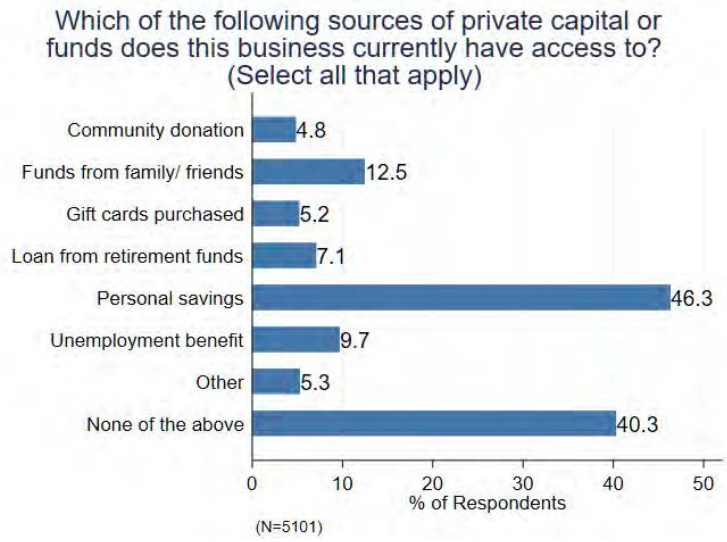

(A) Informal Sources of Business Capital

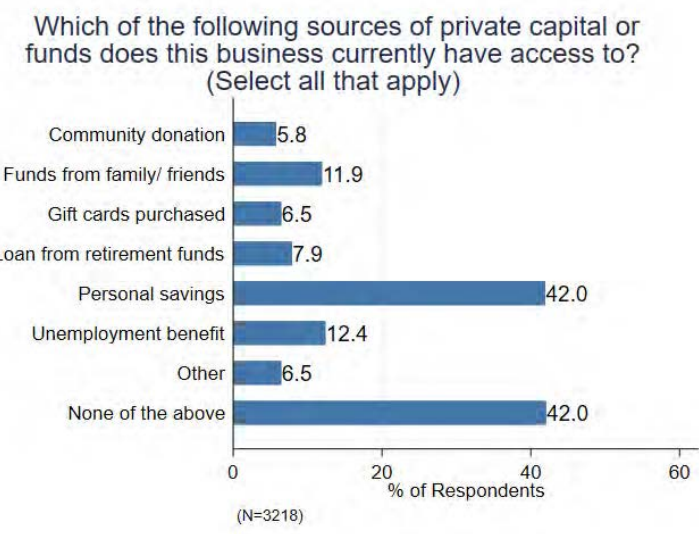

(B) Informal Sources of Business Capital, Employer Firms Only

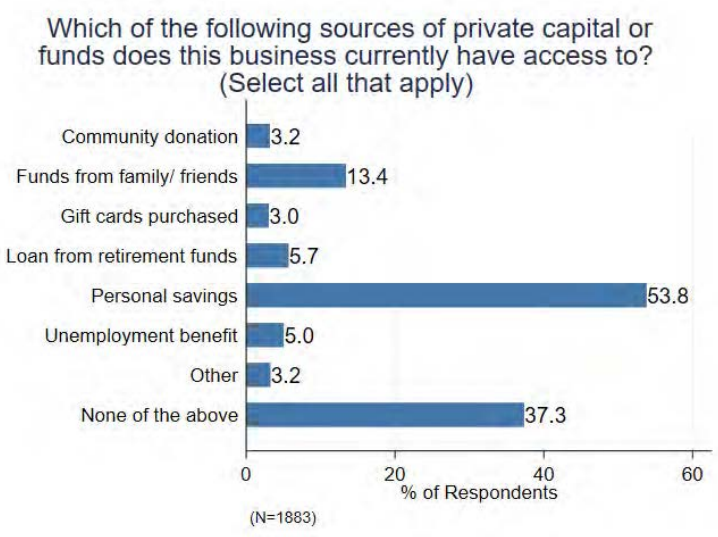

(C) Informal Sources of Business Capital, Non-Employer Firms Only 


\section{Figure 19: Business Cash Flow}

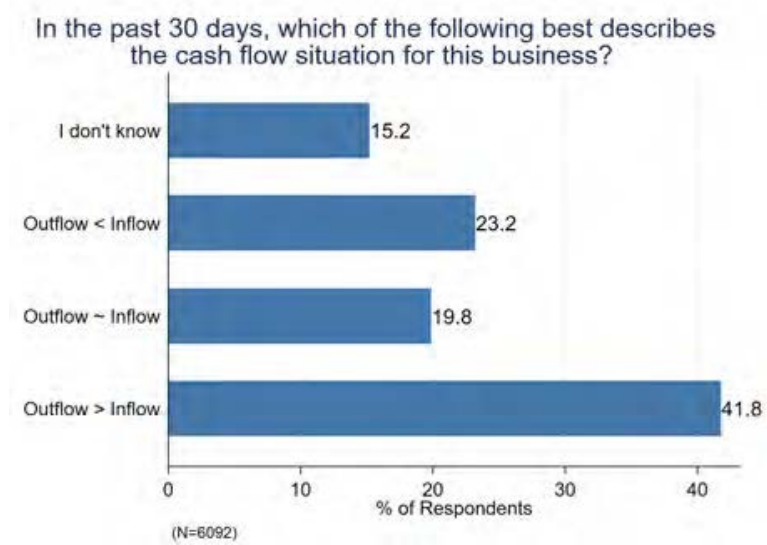

(A) Past Cash Flows

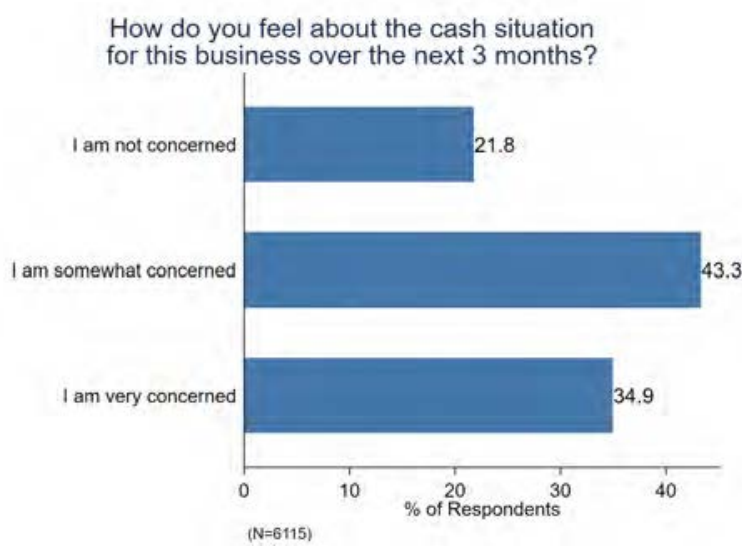

(B) Future Cash Flows

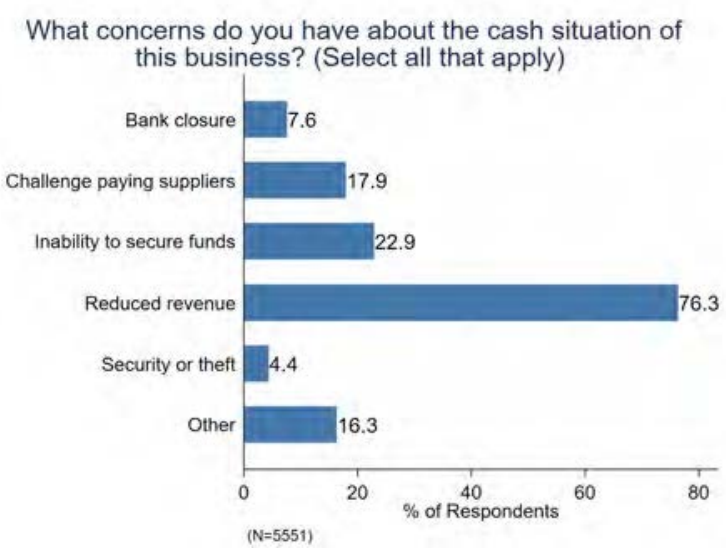

(C) Cash Flow Concerns 


\section{Figure 20: Product Pricing}

How, if at all, did this business change the average prices it charges for its goods or services during the past 30 days?

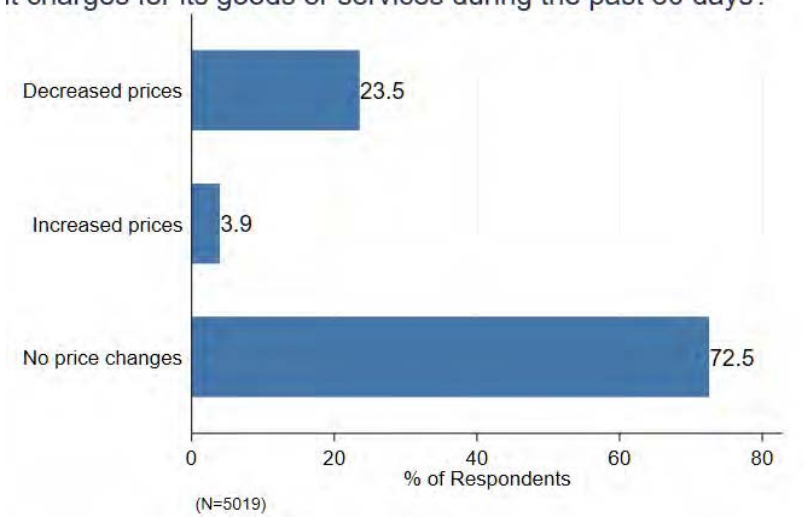

(A) Product Pricing

How, if at all, did this business change the average prices it charges for its goods or services during the past 30 days?

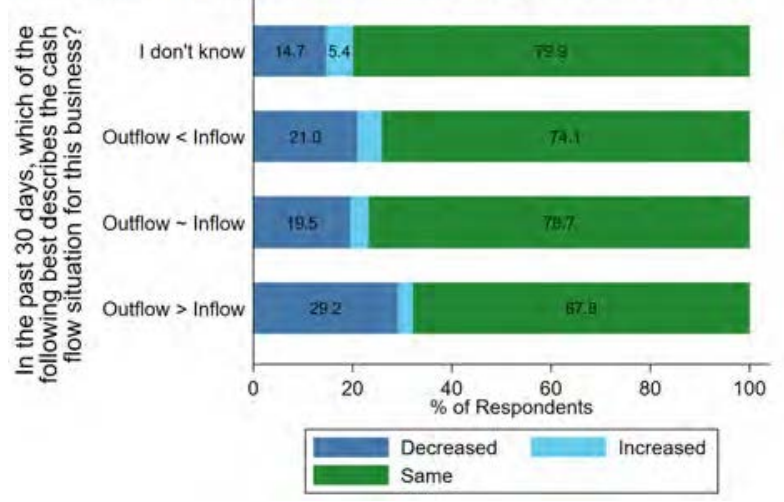

(B) Product Pricing, by Past Cash Flows

How, if at all, did this business change the average prices it charges for its goods or services during the past 30 days?

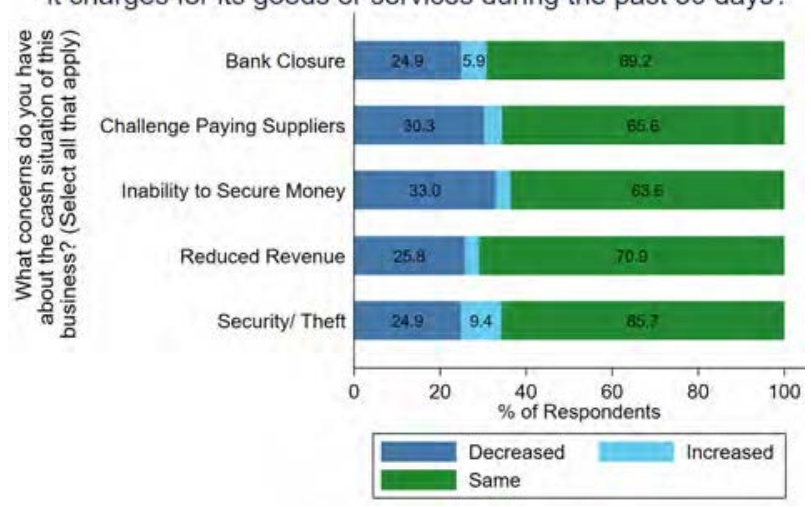

(D) Product Pricing, by Cash Flow Concerns
How, if at all, did this business change the average prices it charges for its goods or services during the past 30 days?

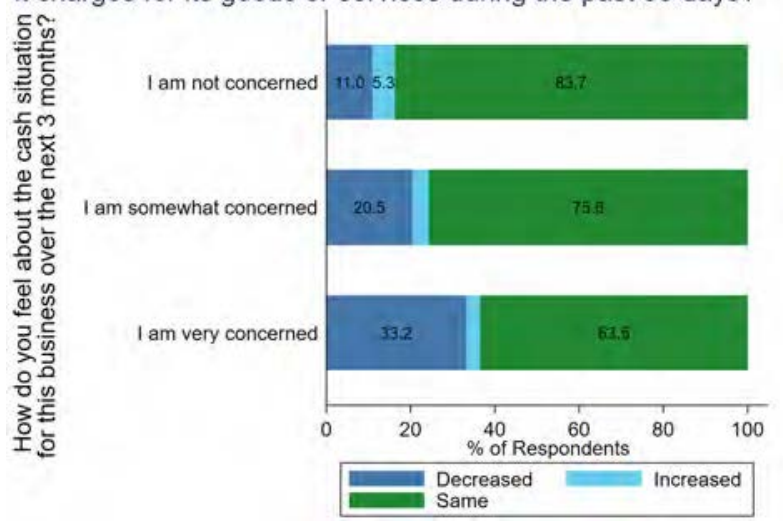

(C) Product Pricing, by Future Cash Flows

How, if at all, did this business change the average prices it charges for its goods or services during the past 30 days?

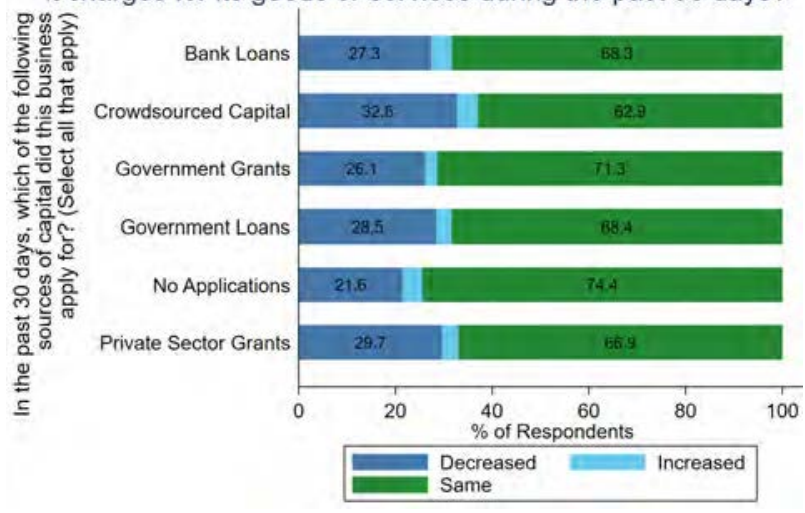

(E) Product Pricing, by Business Applications 


\section{Figure 21: Household Size}

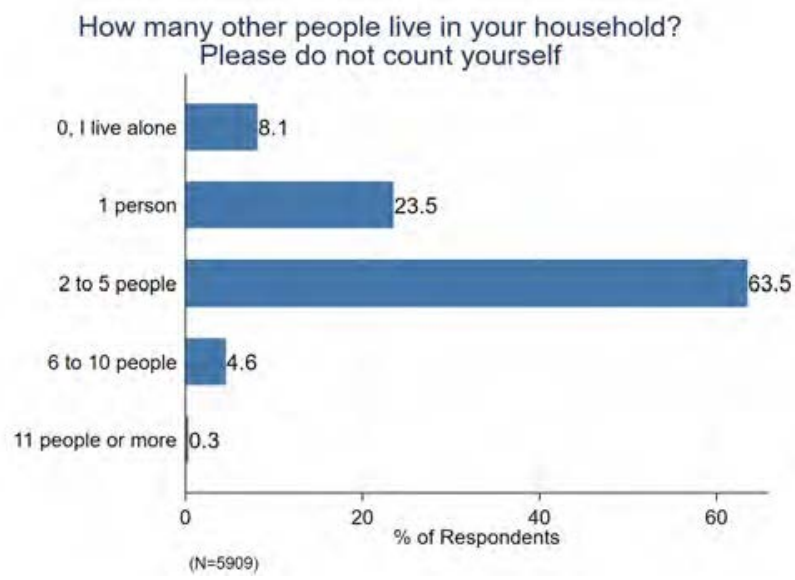

Figure 22: Ease of Work

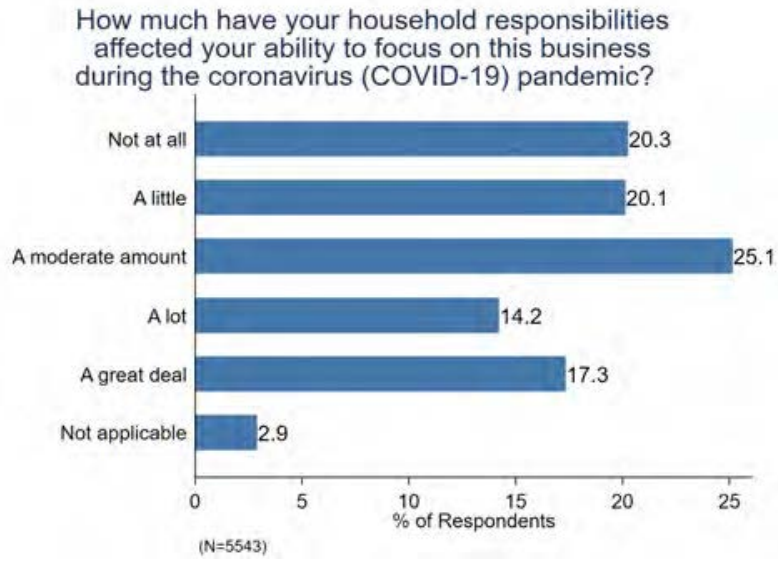

(A) Impact of Household on Business

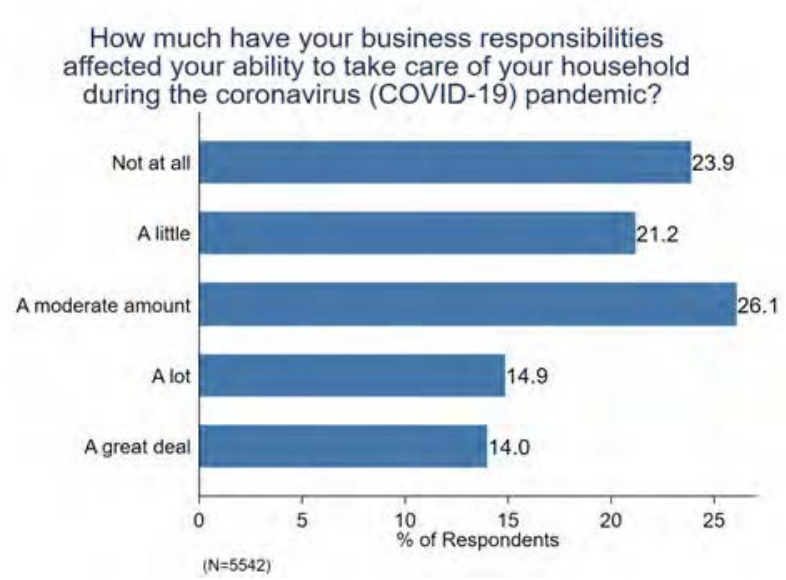

(C) Impact of Business on Household
How much have your household duties affected your ability

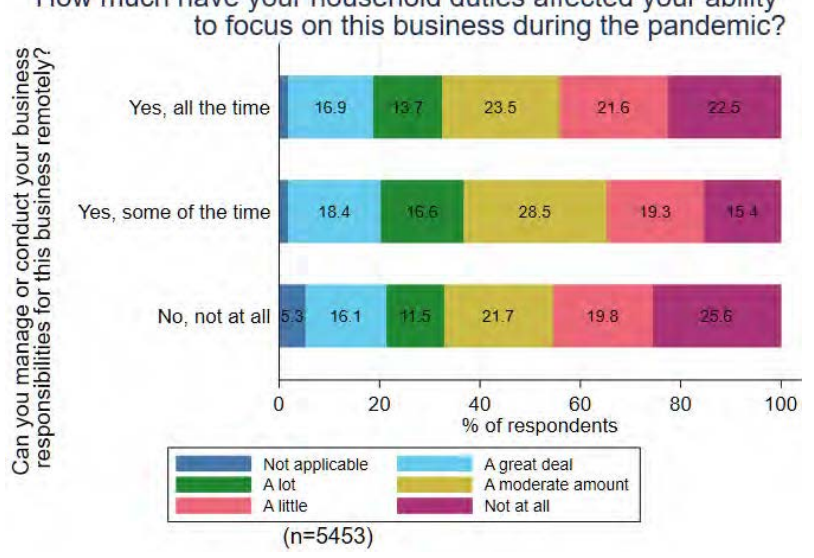

(B) Impact of Household on Business, by Remote Work

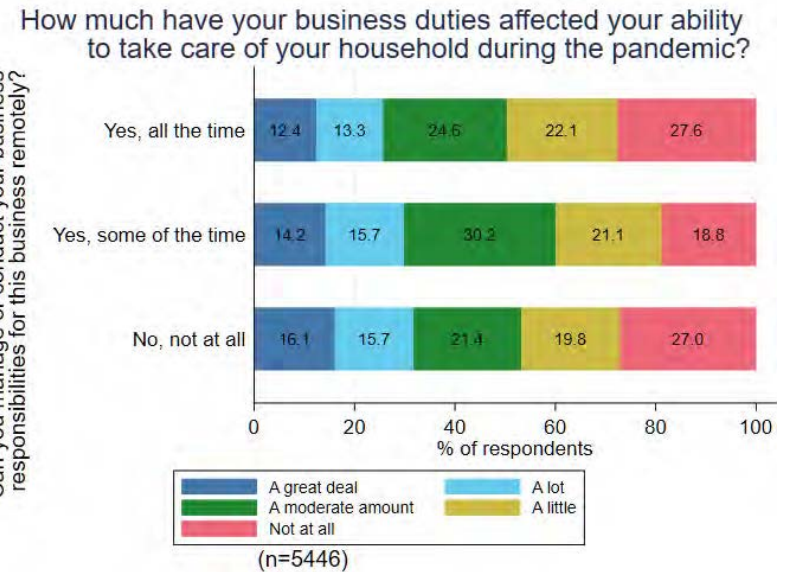

(D) Impact of Business on Household, by Remote Work 


\section{Figure 23: Time Use}

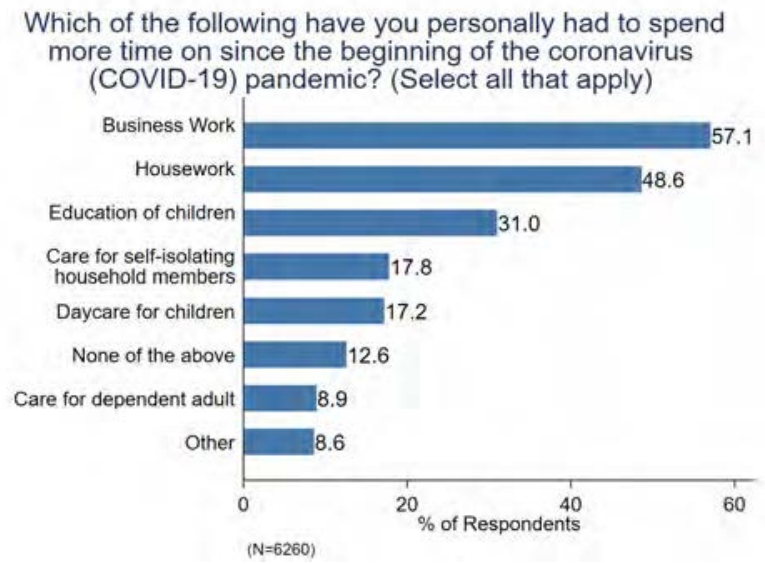

(A) Household Activities

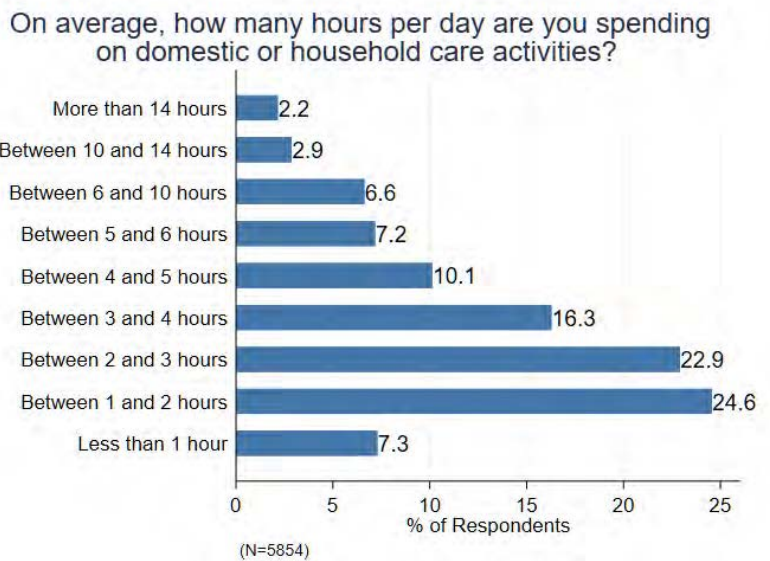

(B) Time Spent on Household Activities

Figure 24: Time Use Crosstabs

How much have your household responsibilities affected your ability to focus on this business during the pandemic?

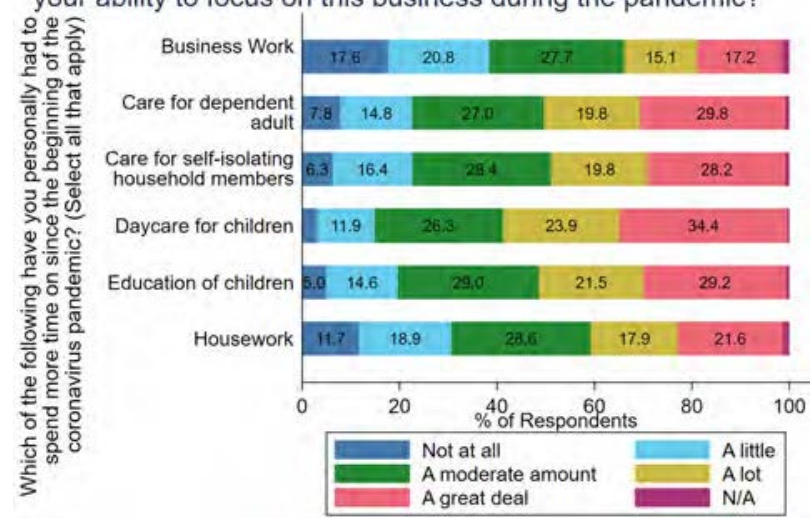

(A) Impact of Household on Business, by Household Activities
How much have your household duties affected your ability to focus on this business during the pandemic?

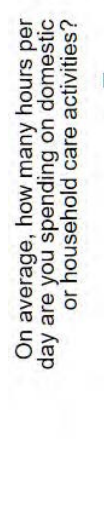

(B) Impact of Household on Business, by Time Spent on Household Activities

Figure 25: Household Income and Expenses

In the past 30 days, how easy or difficult has it been to pay your household's usual expenses?

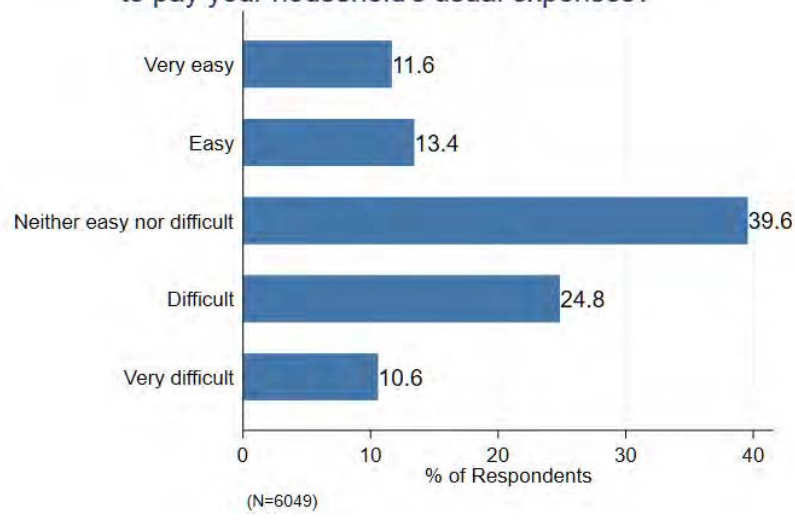

(A) Household Expenses

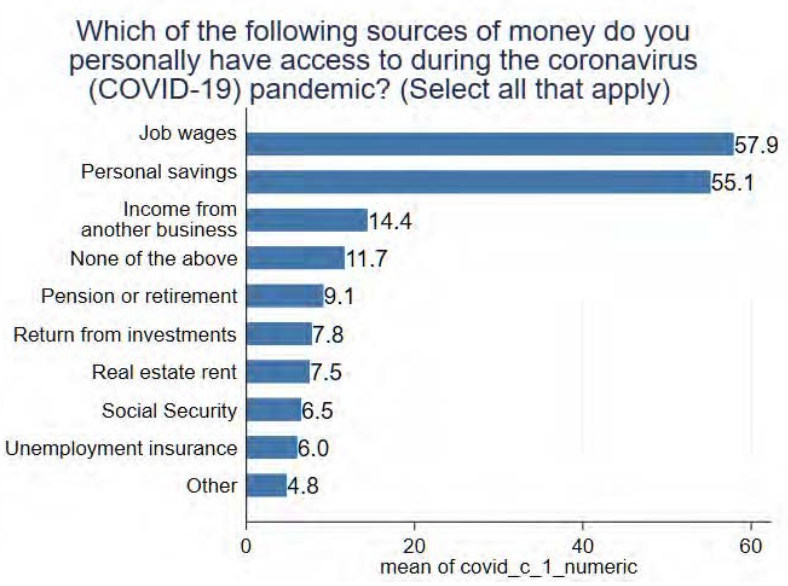

(B) Personal Finances 


\section{Figure 26: Business Employment Changes}

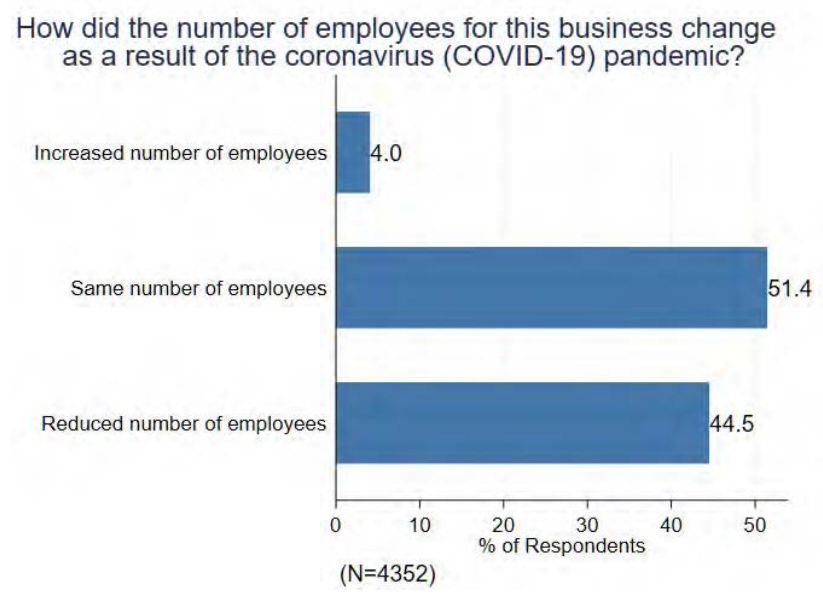

(A) Employment Change

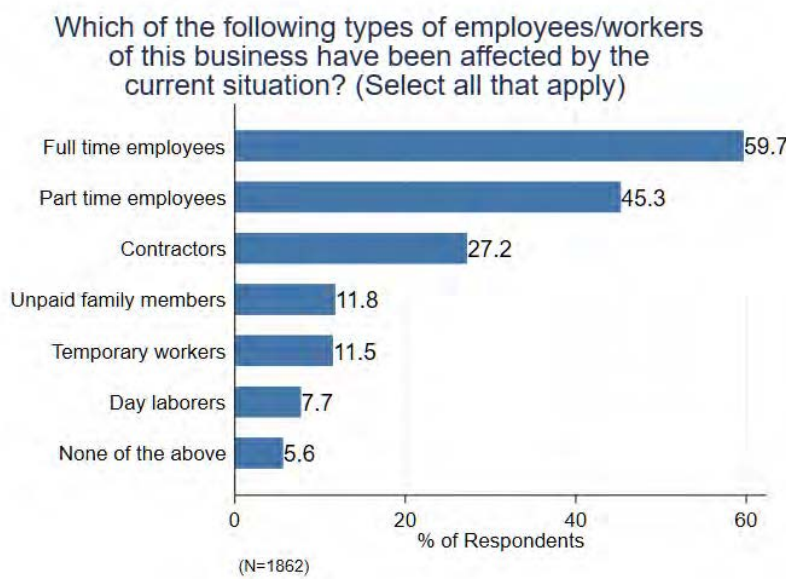

(C) Type of Workers
Were these employees/workers laid off or furloughed?

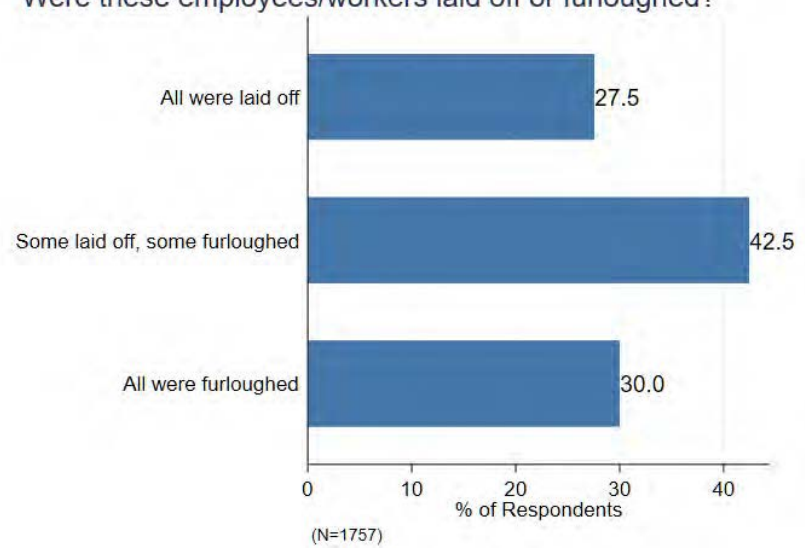

(B) Type of Change

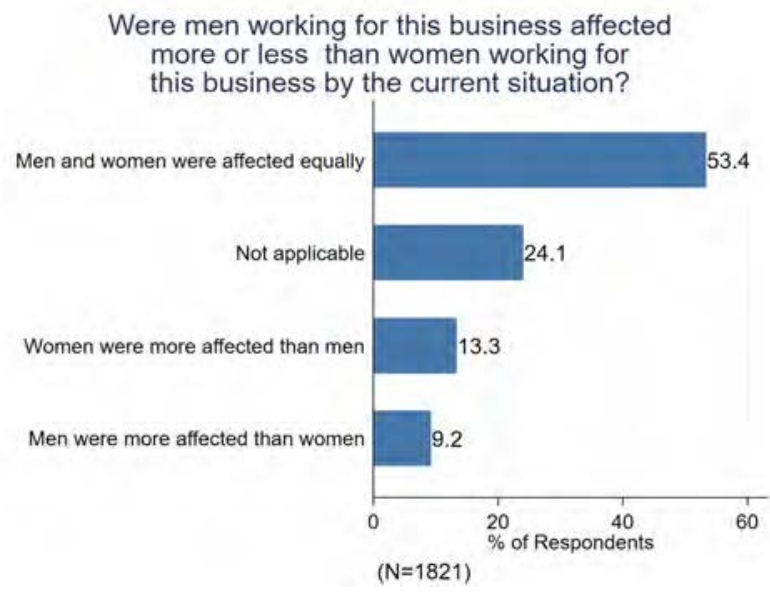

(D) Effect by Gender 


\section{Figure 27: Business Employment Changes Crosstabs}

How did the number of employees for this business change as a result of the coronavirus (COVID-19) pandemic?

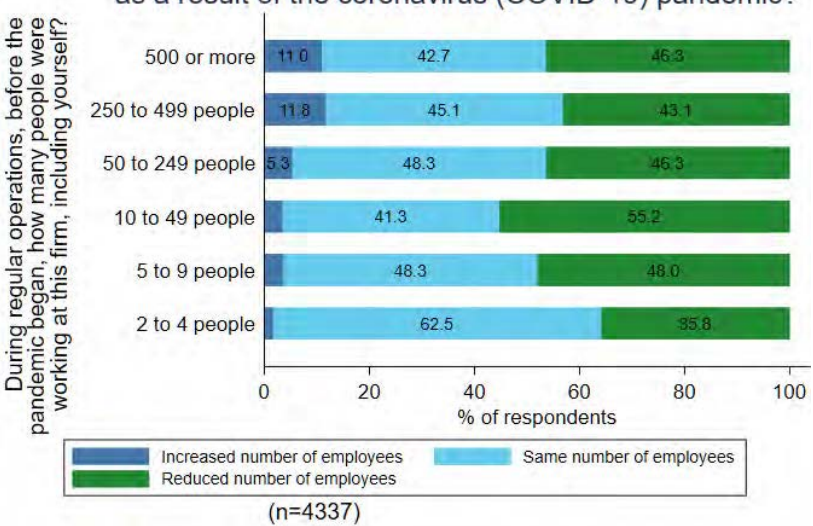

(A) Employment Change, by Firm Size

How did the number of employees for this business change

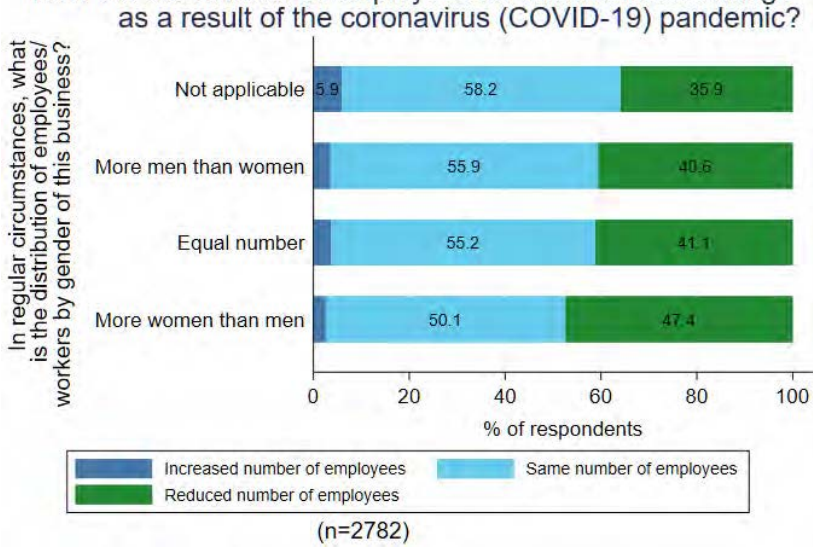

(C) Employment Change, by Gender Balance
How did the number of employees for this business change as a result of the coronavirus (COVID-19) pandemic?

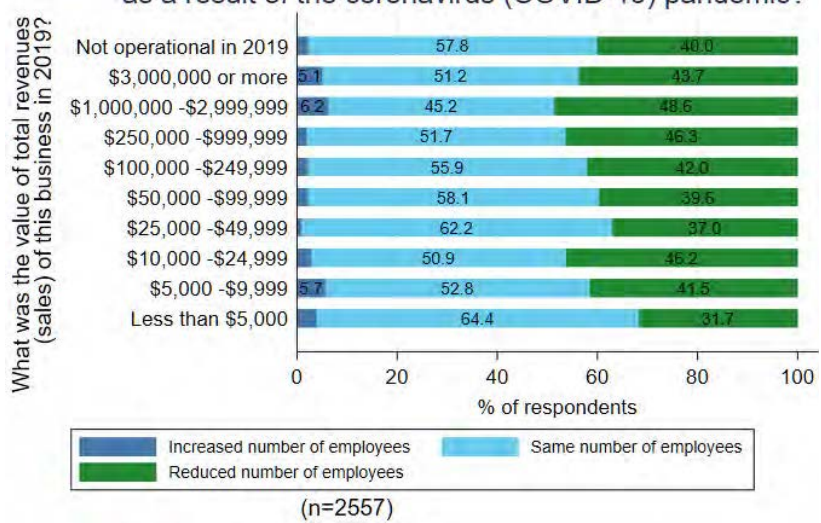

(B) Employment Change, by Sales

How did the number of employees for this business change as a result of the coronavirus (COVID-19) pandemic?

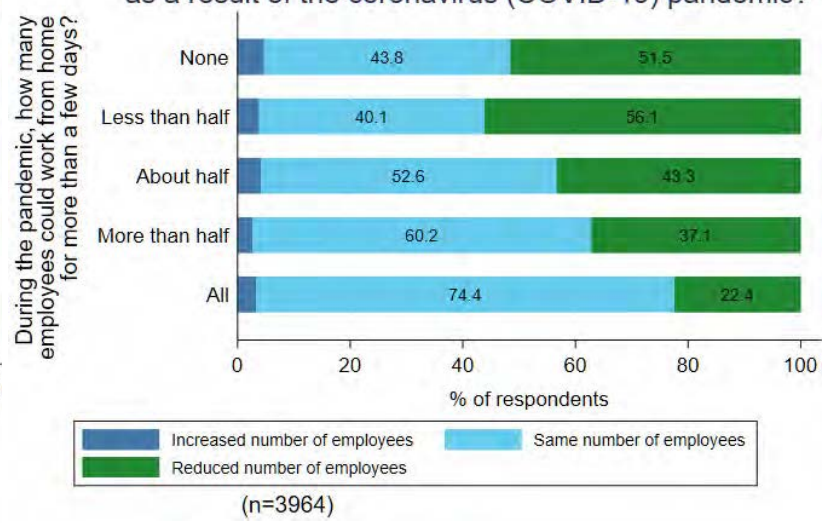

(D) Employment Change, by Work From Home Abilities 
Figure 28: Business Employees - Work From Home

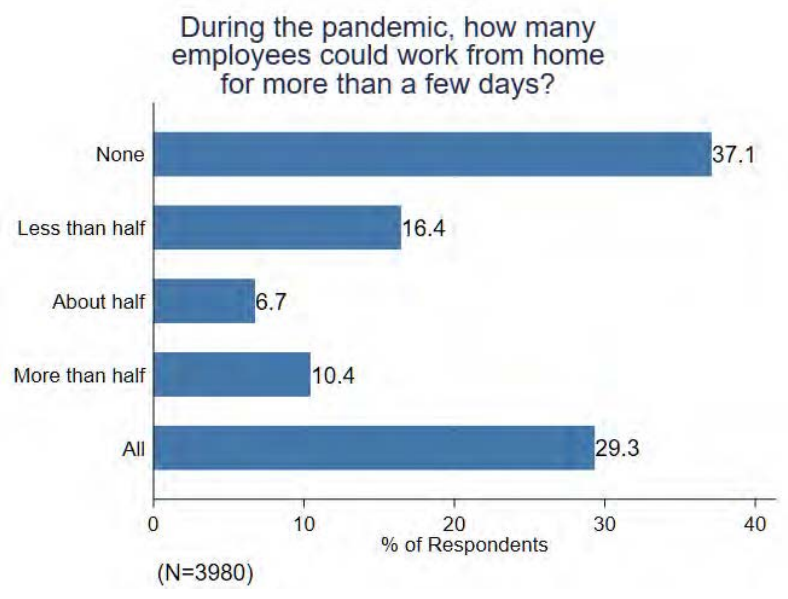

(A) Work From Home Access

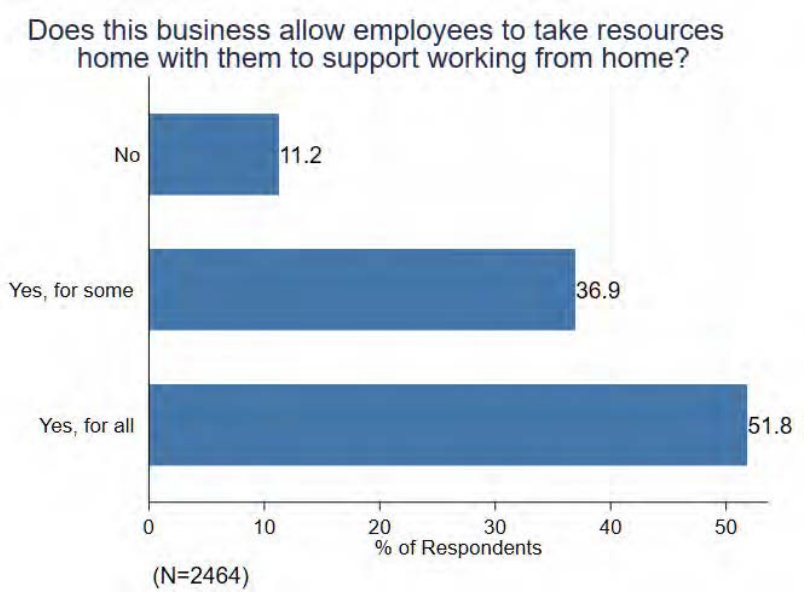

(B) Work From Home Support

Figure 29: Share of employees reported to be able to work from home in comparison to the Dingel and Neiman (2020) measure of remote work feasibility

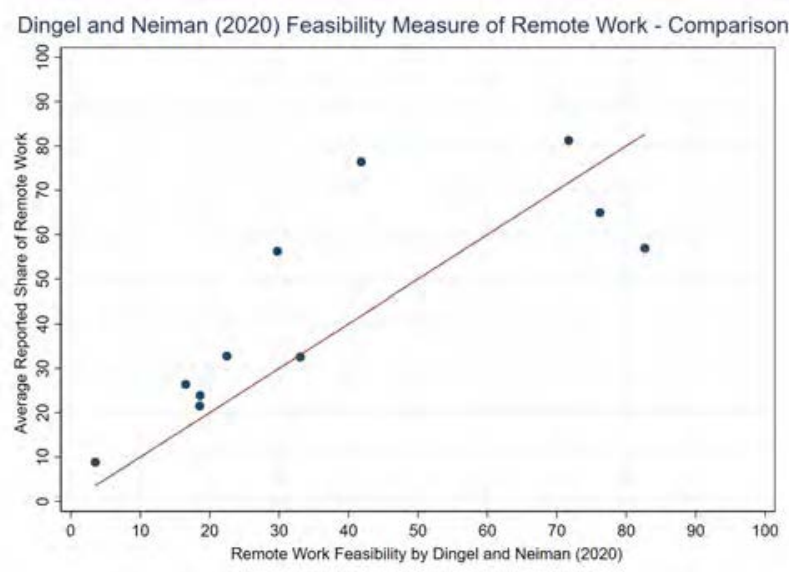

We assumed a share of $100 \%, 75 \%, 50 \%, 25 \%$ and $0 \%$ if the respondent stated that "all", "more than half", "about half", "less than half", and "none" of their employees could work remotely, respectively. The Dingel and Neiman (2020) measure is based on pre-crisis surveys describing the typical experience of U.S. workers for each industry. The statistics match very well with a Pearson correlation coefficient of $80.5 \%$. 
Figure 30: Business Employee Risk \& Protection

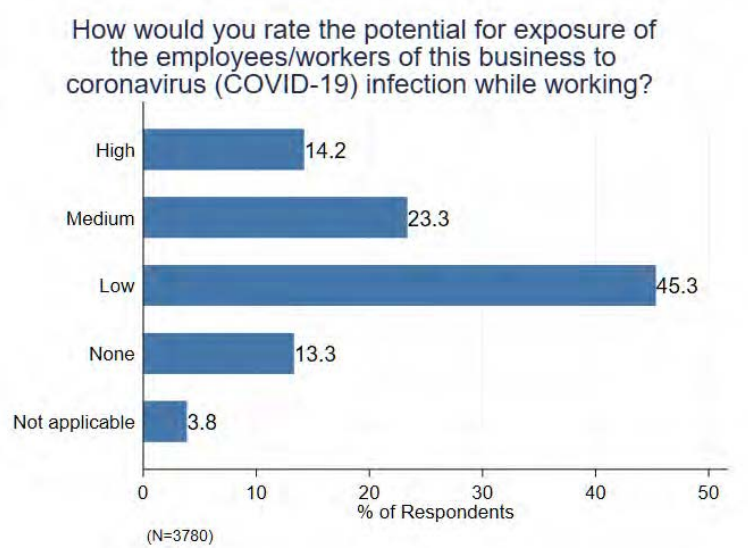

(A) Employee Risk

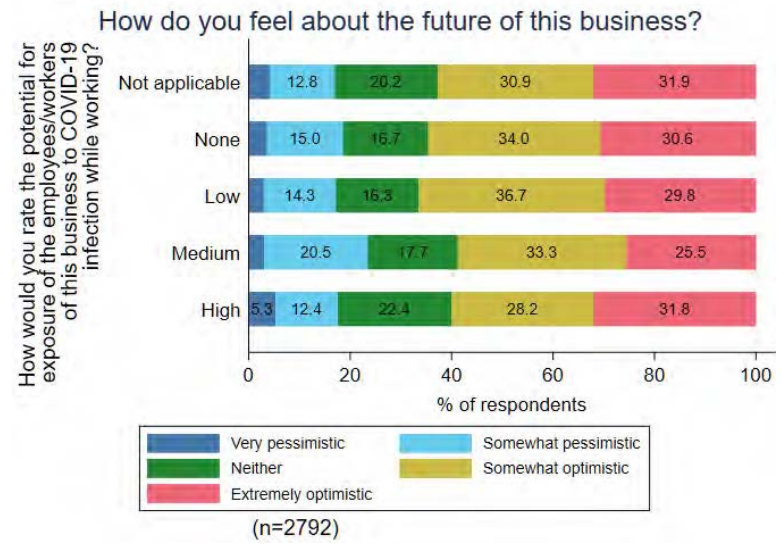

(B) Employee Risk and Optimism about Business Future

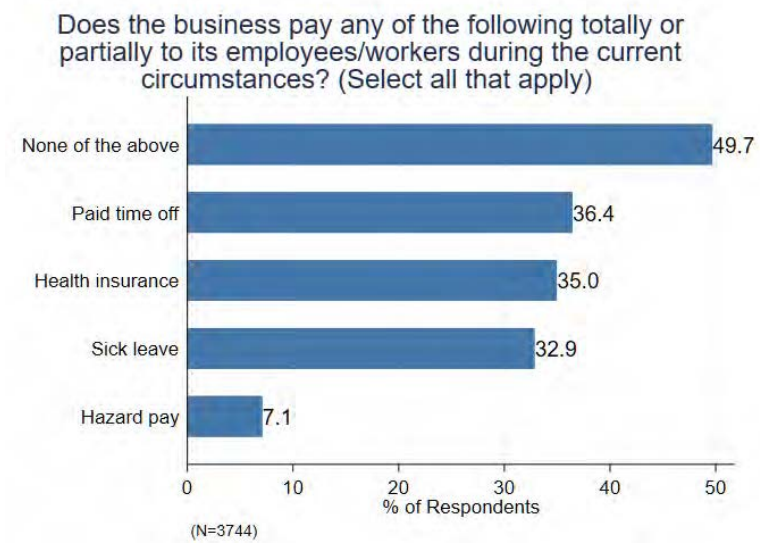

(D) Employee Support Pay

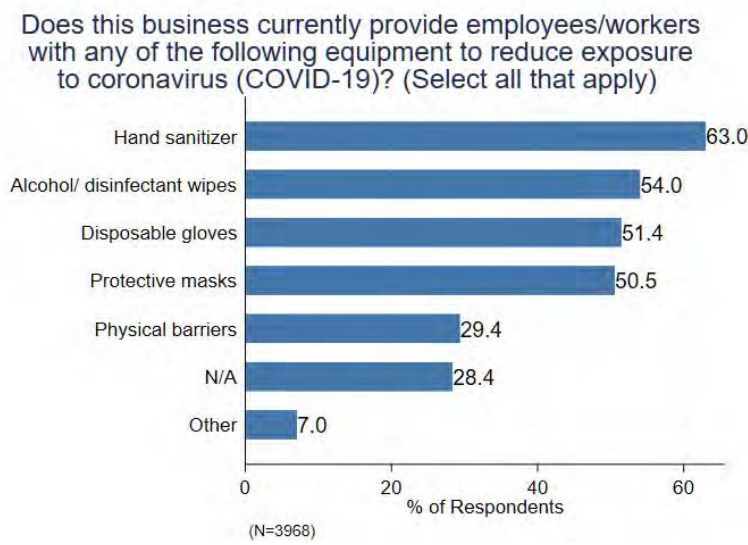

(C) Employee Protection 


\section{Figure 31: Employee Risk Crosstabs}

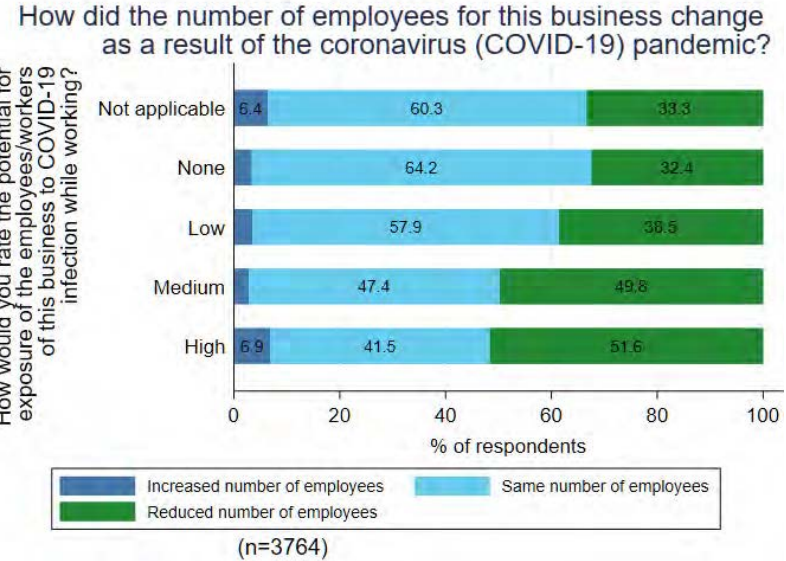

(A) Employment Change, by Employee Risk

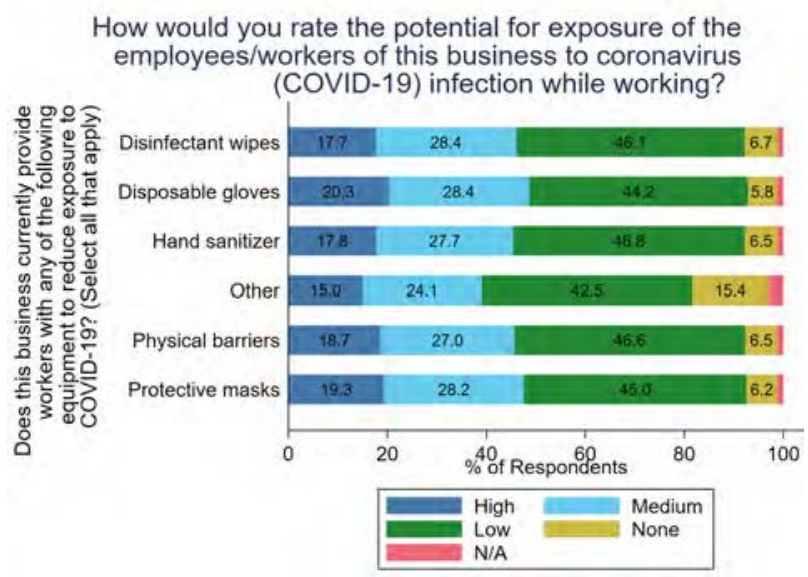

(B) Employee Risk, by Employment Protection

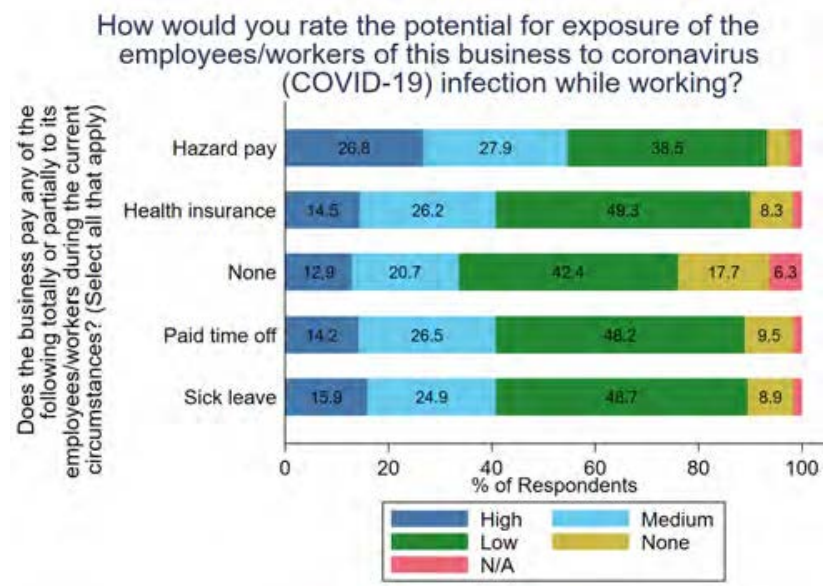

(C) Employee Risk, by Employee Pay

Figure 32: Client Accommodation

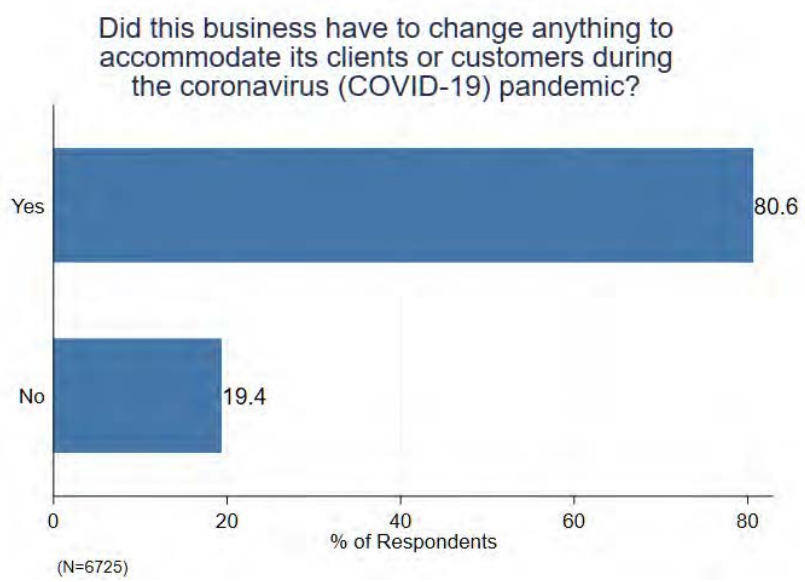

(A) Accommodation for Clients

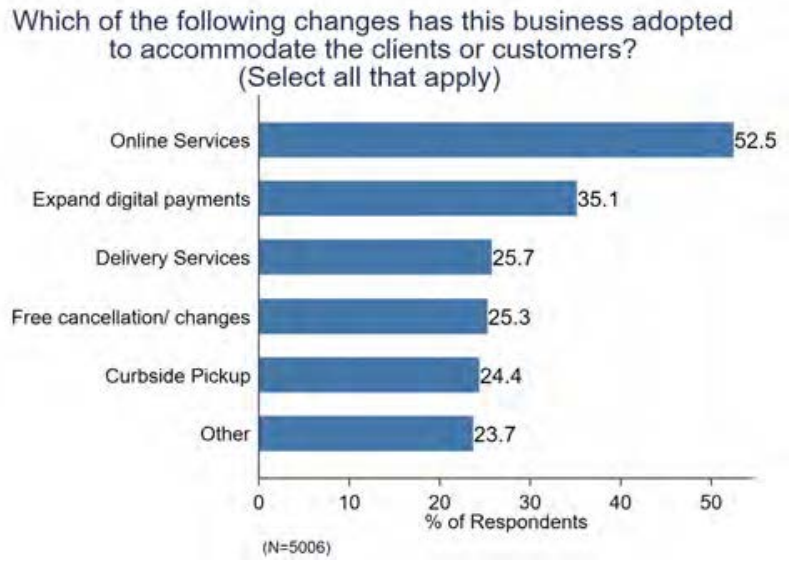

(B) Types of Adjustments for Clients 


\section{Figure 33: Business Adjustments}

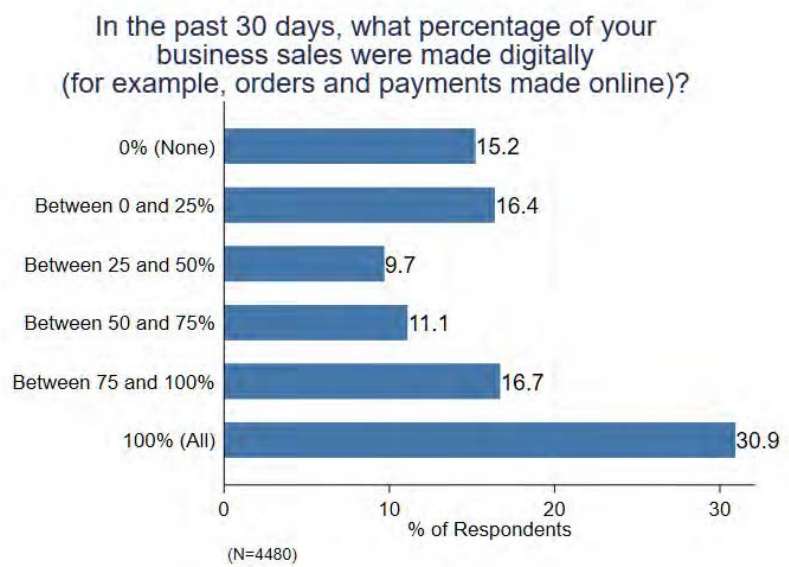

(A) Online Sales

Which of the following changes has this business made to assure needed supplies are available during the coronavirus

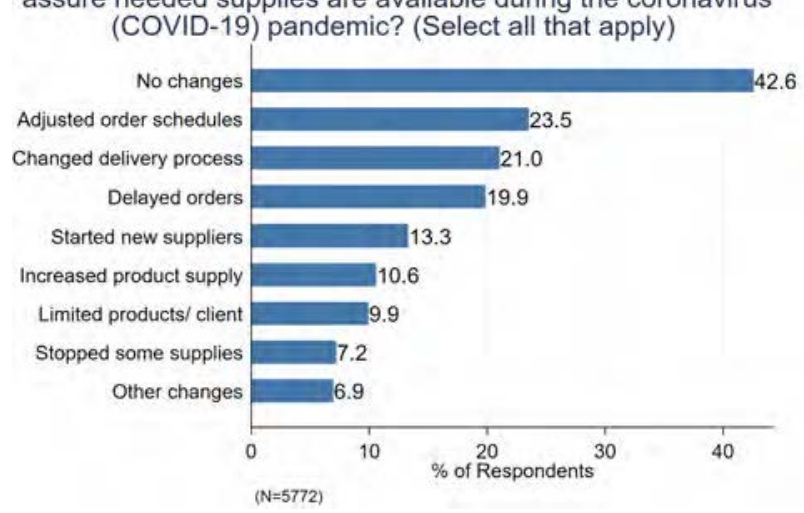

(C) Supply Changes

Which of the following has this business used in the past 30 days to continue operating during the coronavirus

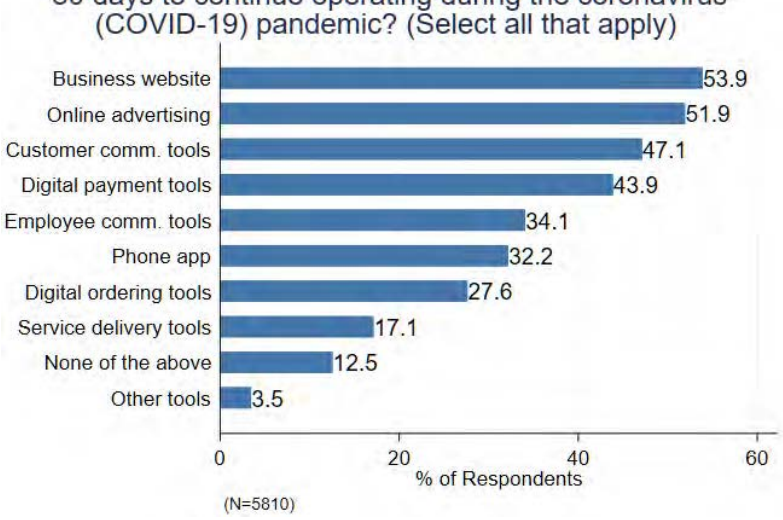

(B) Business Tools

How easy or difficult is it for this business to change the delivery of goods or services as a result of the

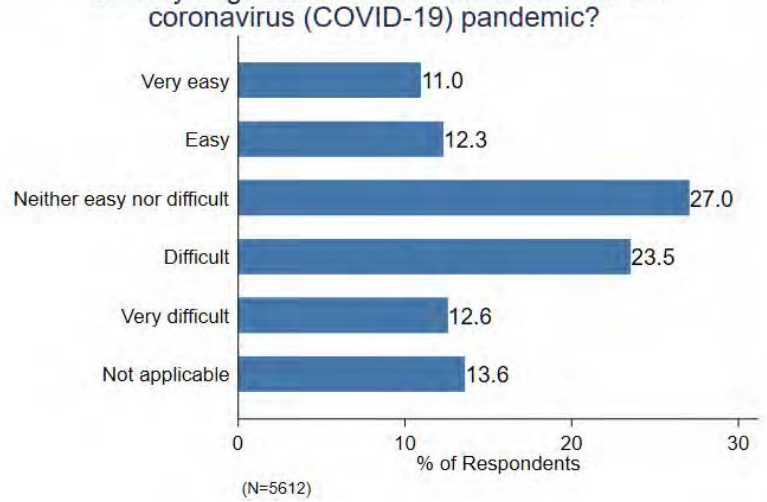

(D) Ease of Change 


\section{Figure 34: Business Information}

Do you feel that you have access to enough information to make decisions about this business during the coronavirus

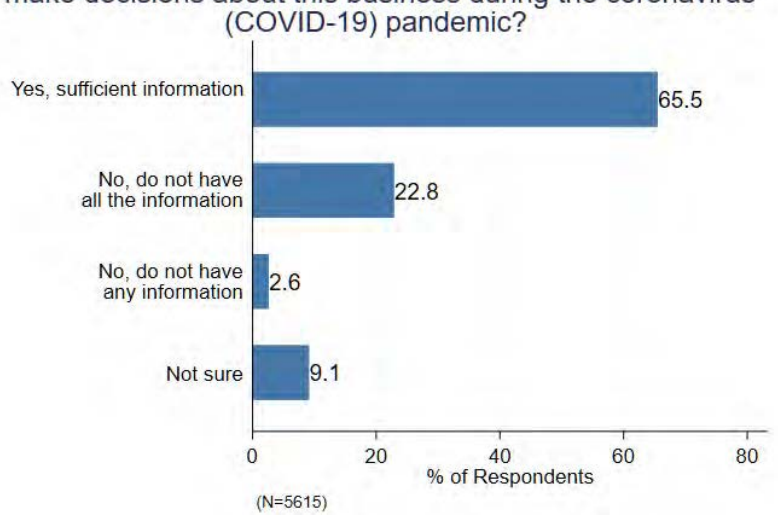

(A) Access to Information

Do you feel that you have access to enough information to make decisions about this business during the pandemic?

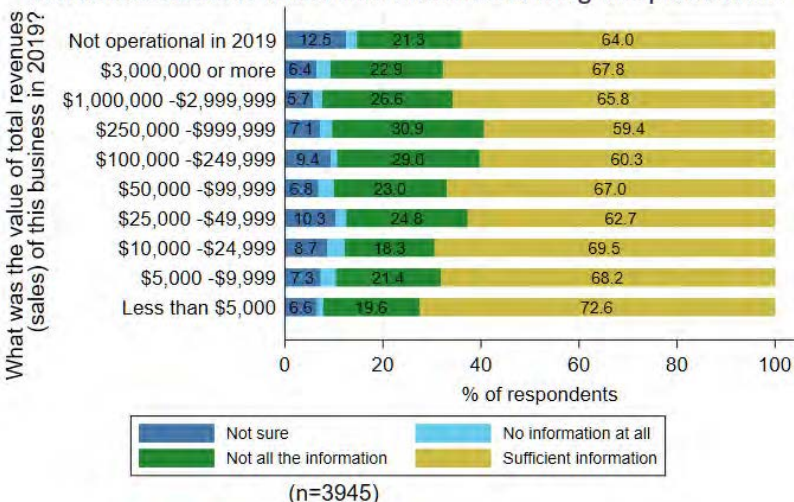

\section{(C) Access to Information, by Sales}

Do you feel that you have access to enough information to make decisions about this business during the pandemic?

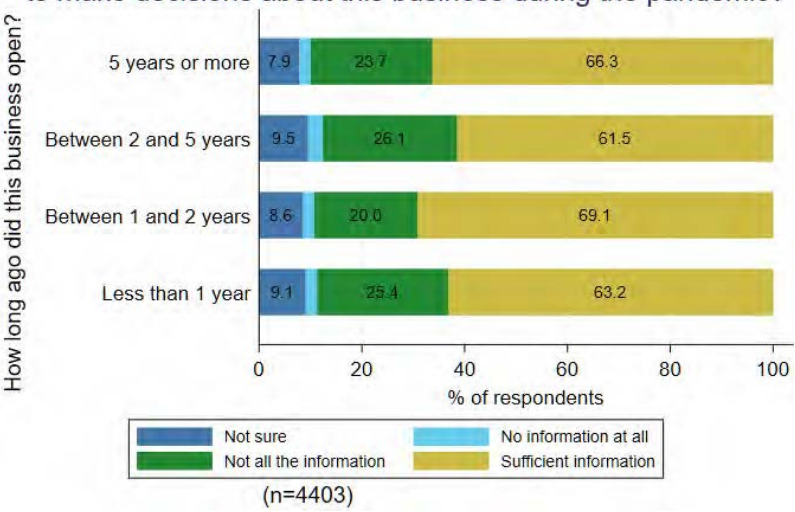

(E) Access to Information, by Firm Age
Where do you receive information about how this business could get support during the coronavirus

(COVID-19) pandemic? (Select all that apply)

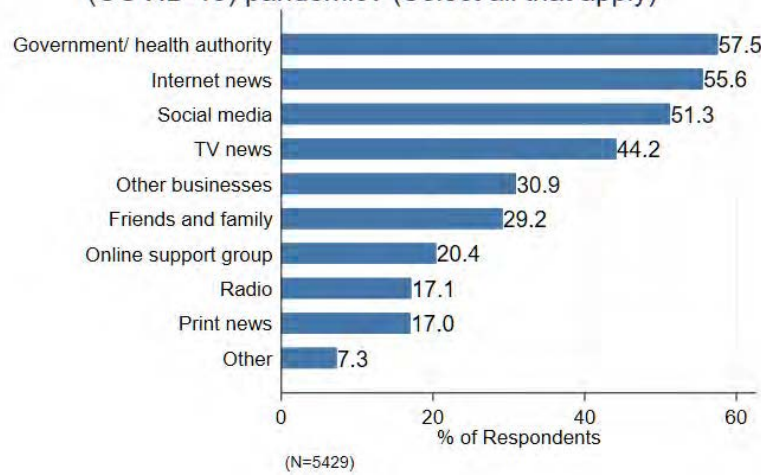

(B) Information Sources

Do you feel that you have access to enough information to make decisions about this business during the pandemic?

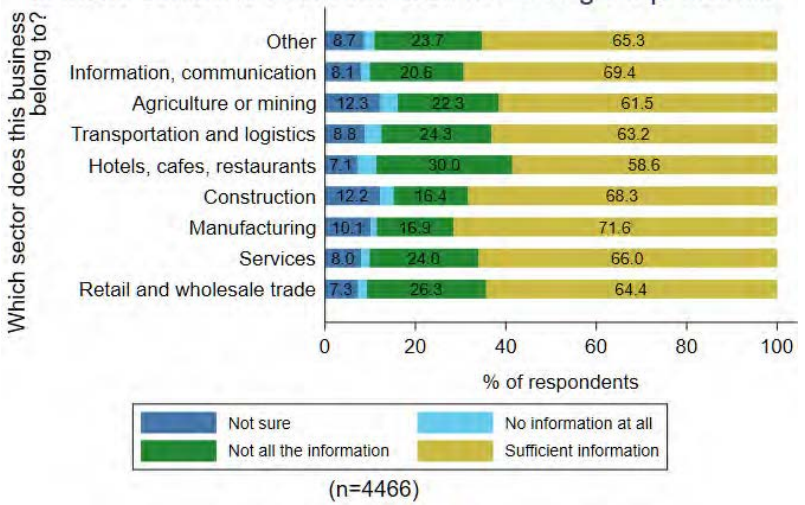

(D) Access to Information, by Sector

Do you feel that you have access to enough information to make decisions about this business during the pandemic?

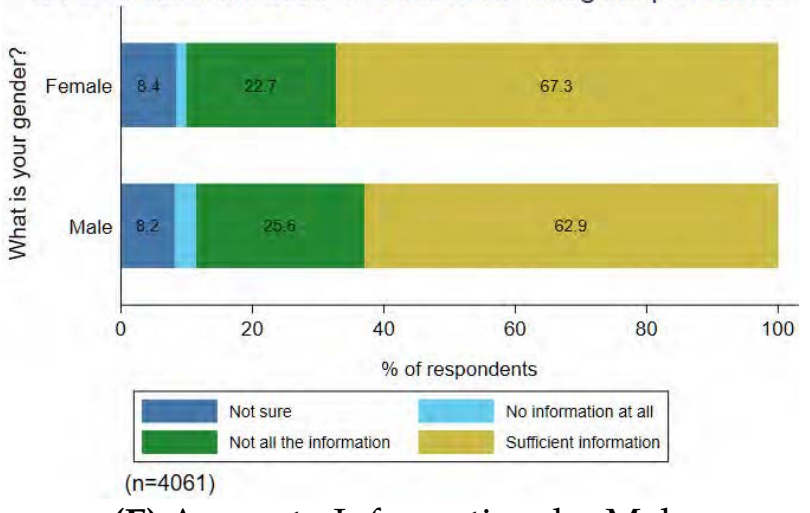

(F) Access to Information, by Male owned/managed 


\section{Figure 35: Business Closure}

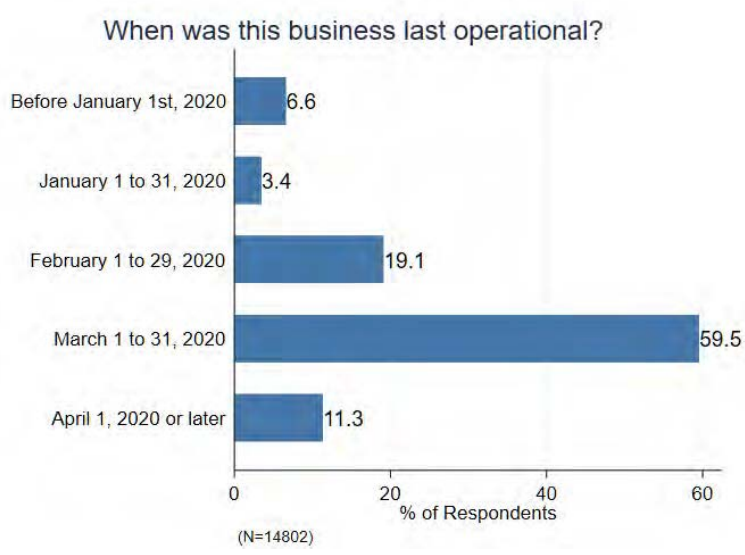

(A) Date of Closing

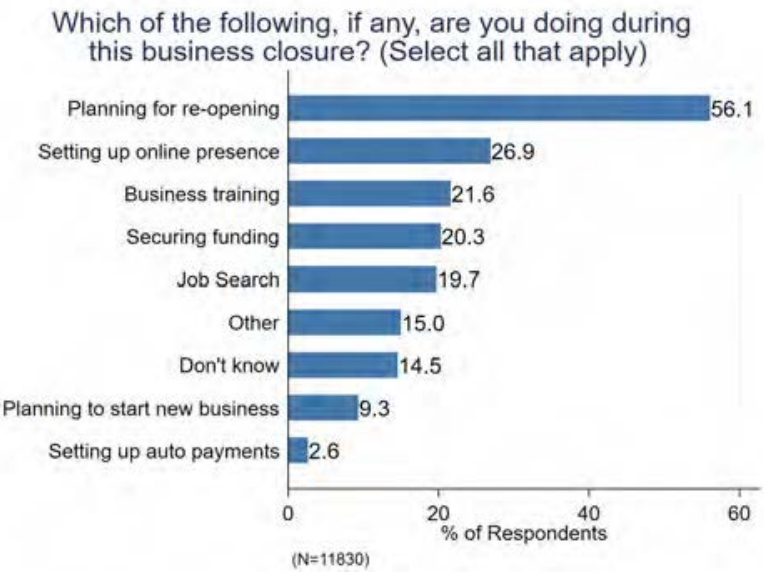

(B) Activities during Business Closure

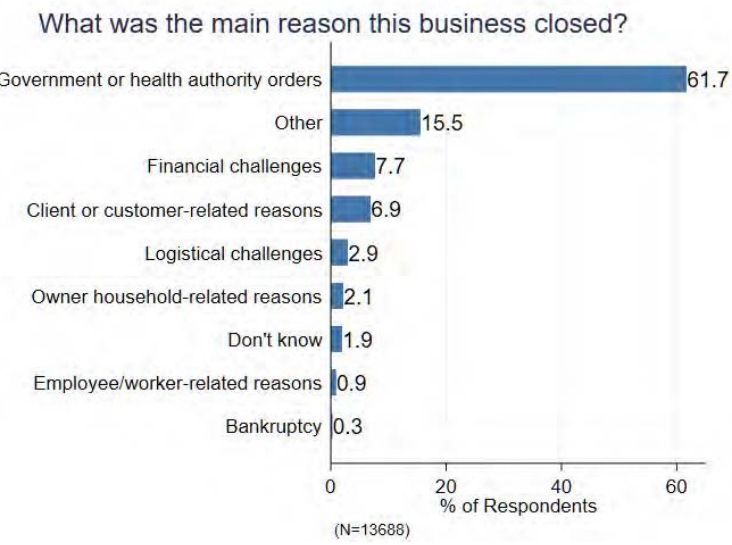

\section{(C) Reason for Closing}




\section{Figure 36: Business Re-opening}

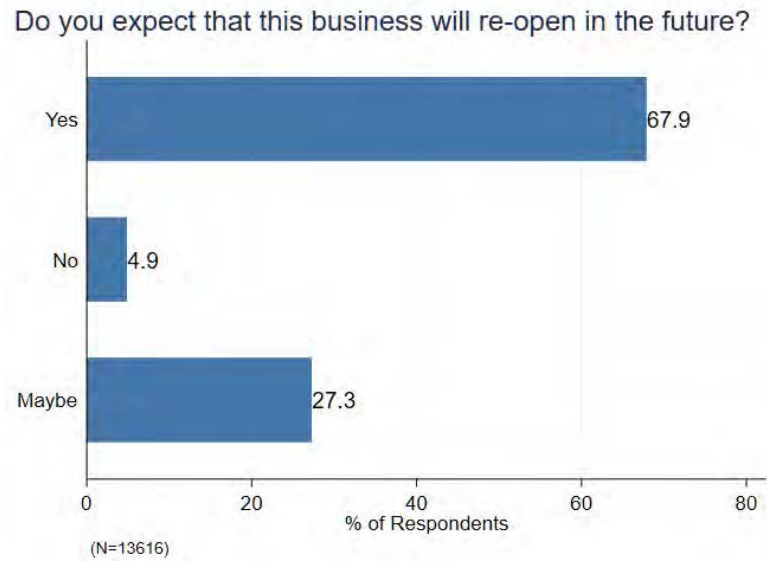

(A) Plans to Re-open

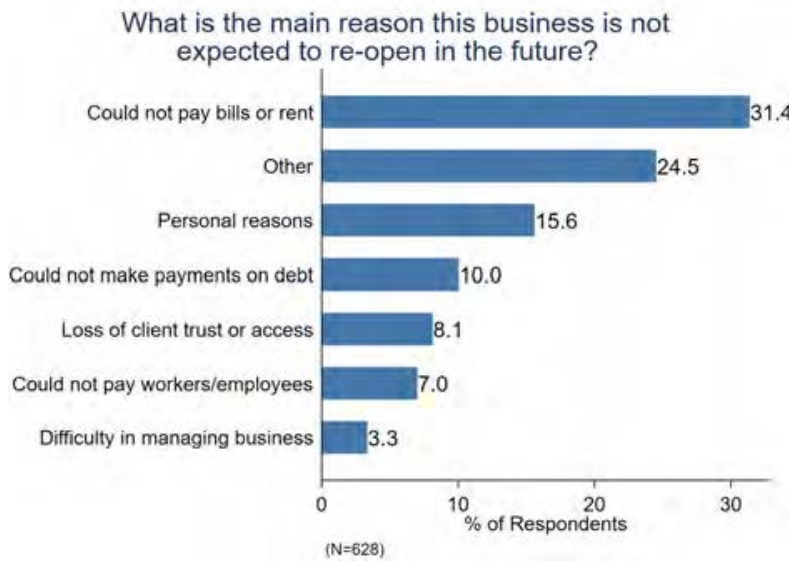

(C) Reason for Not Opening
Do you expect that this business will re-open in the future?

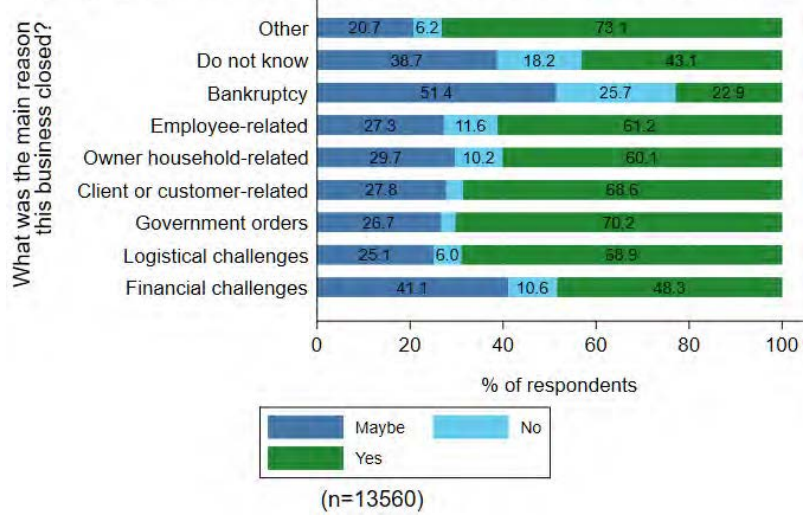

(B) Re-opening Expectations, by Closure Reason

What would be the most important action for this business

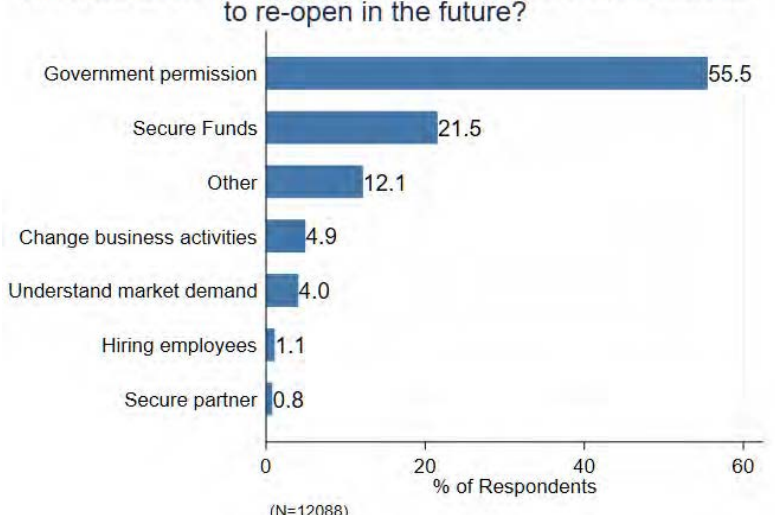

(D) Actions for Opening

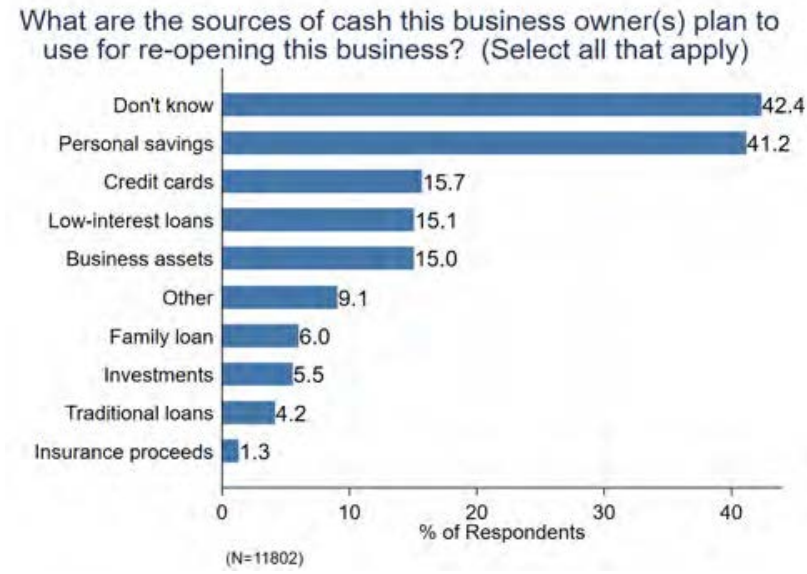

(E) Cash Sources for Opening 


\section{Figure 37: Business Future}

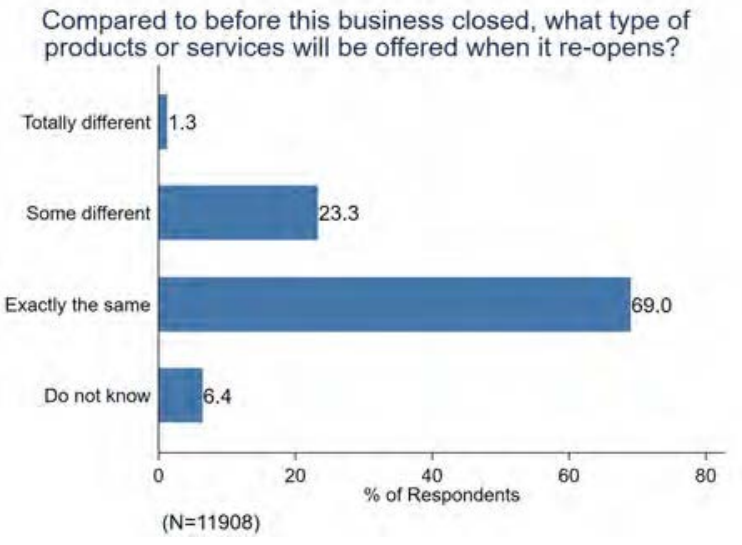

(A) Future Products

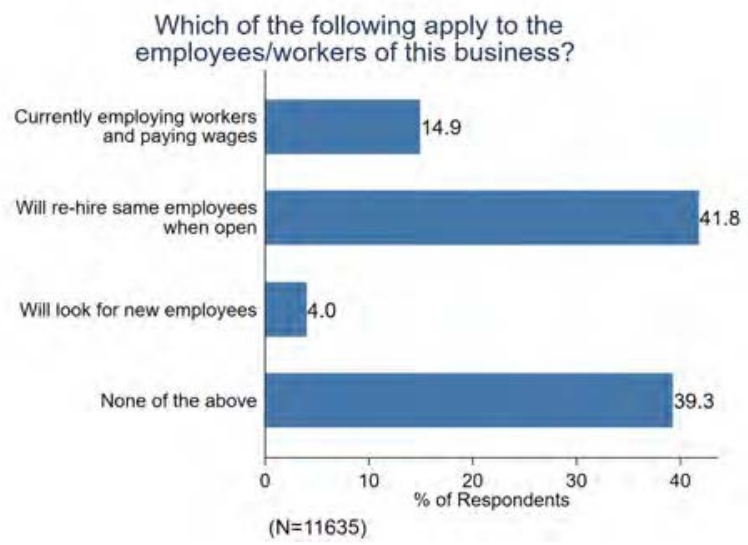

(B) Future Employment

Figure 38: Business Challenges and Support

In which of the following is this business facing the most challenges and would need support with to survive

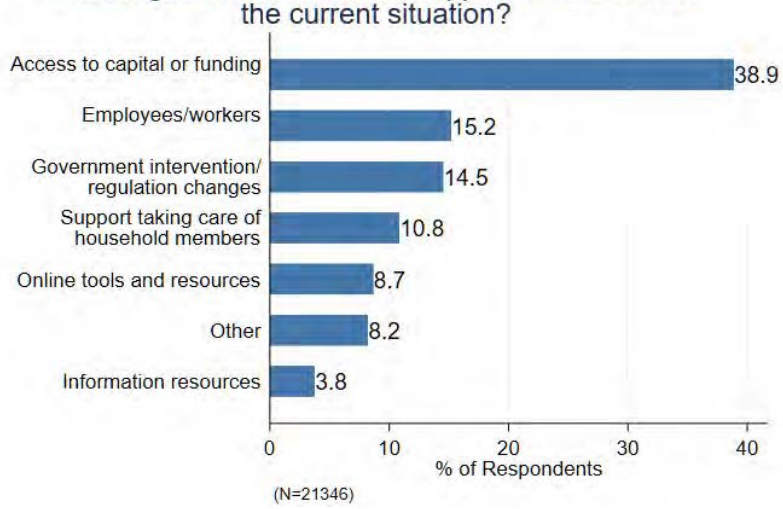

(A) Business Challenges
What would be the three most needed policies to support this business over the COVID-19 crisis? (Select at most 3)

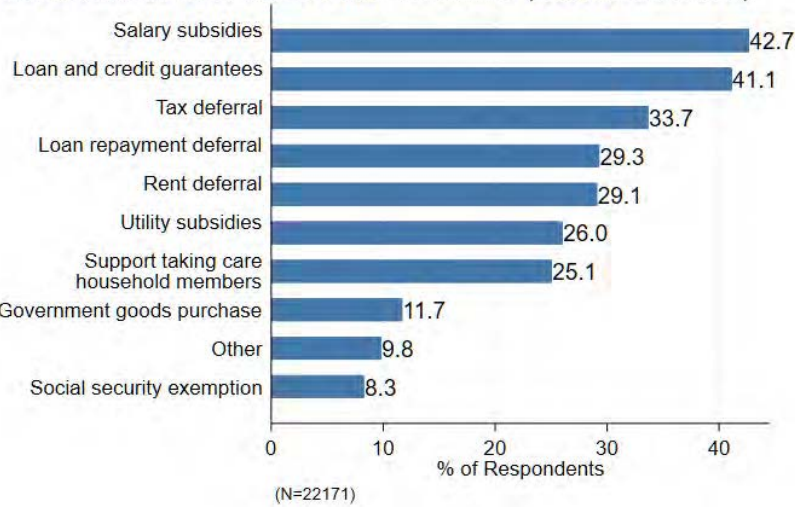

(B) Business Support 


\section{Figure 39: Business Challenges}

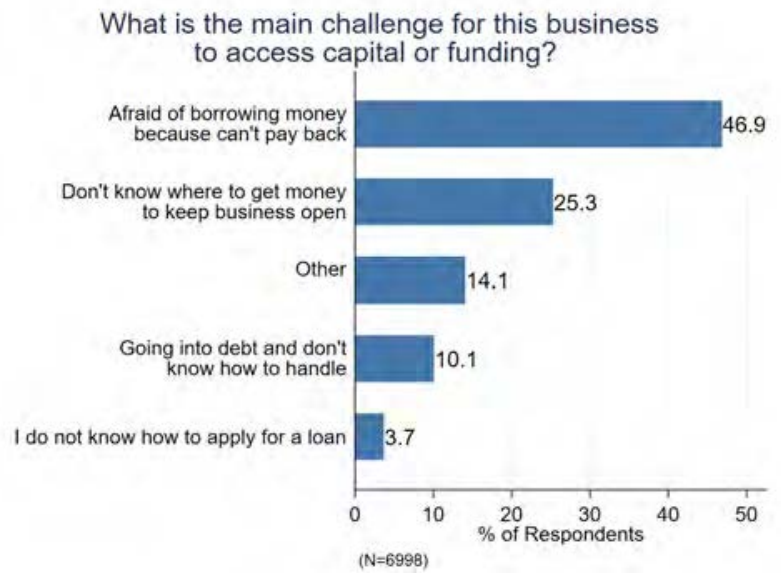

(A) Funding Challenges

What is the main challenge this business is facing with respect to government interventions or regulation changes?

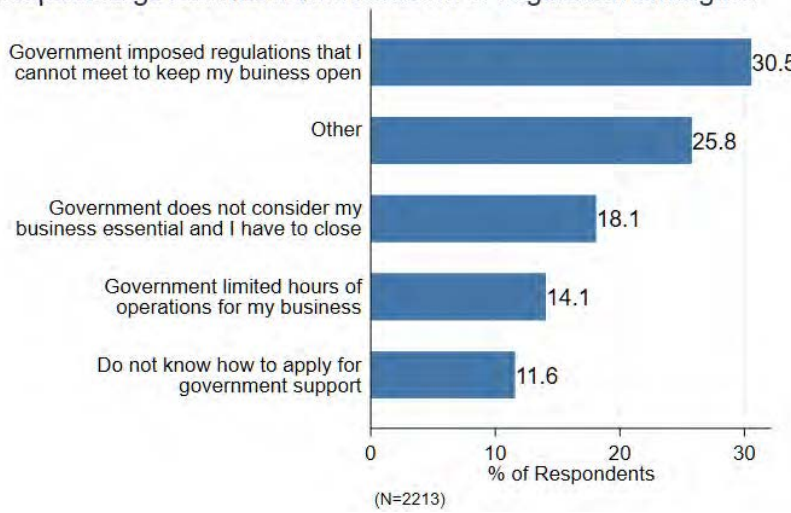

(C) Government Challenges

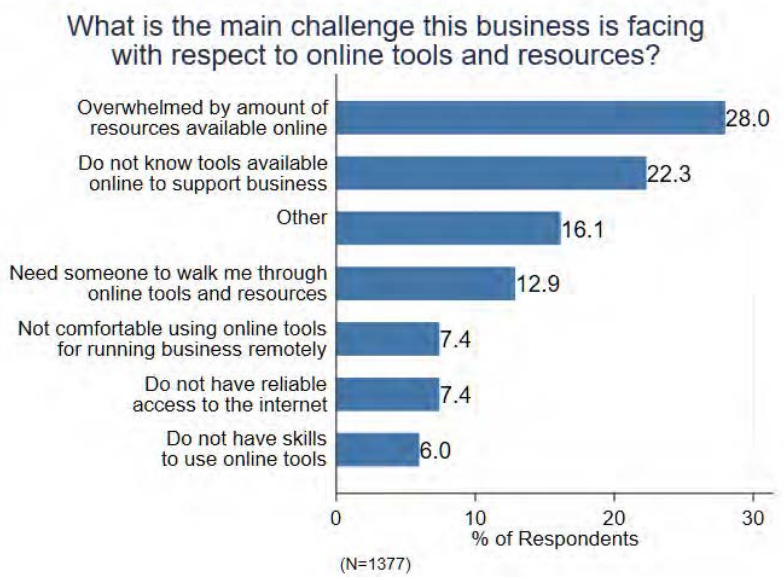

(E) Online Tool Challenges
What is the main challenge this business is facing when it comes to employees/workers?

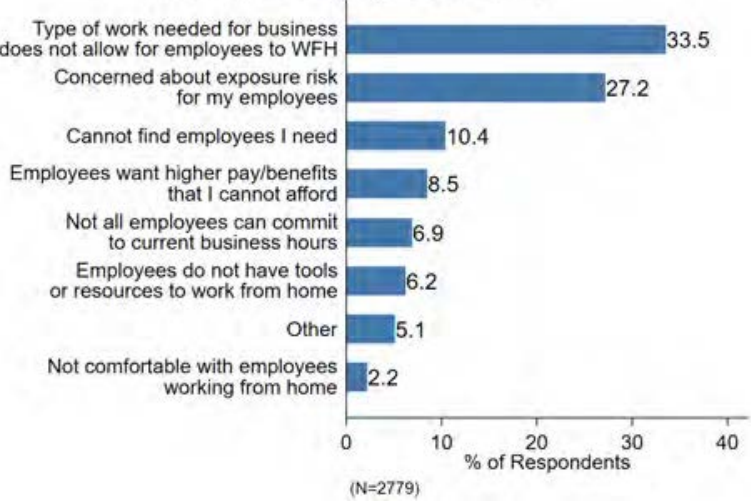

(B) Employee Challenges

What is the main challenge you are facing when it comes to supporting members of your household?

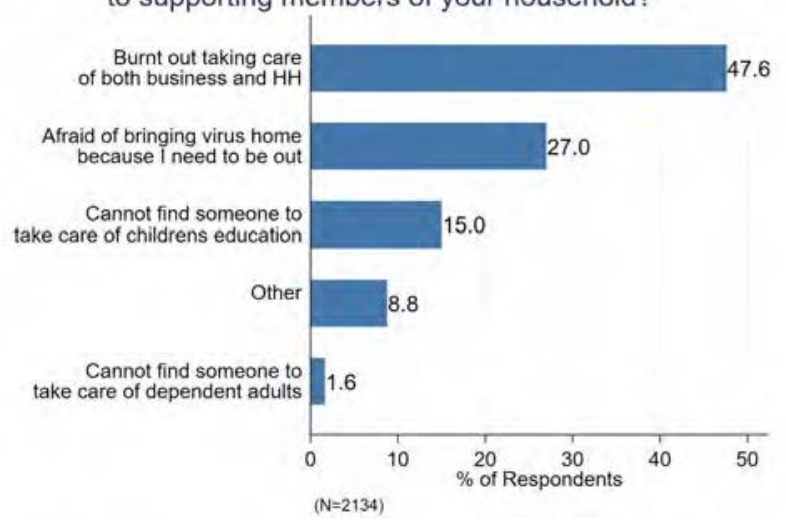

(D) Household Support Challenges

What is the main challenge this business is facing with

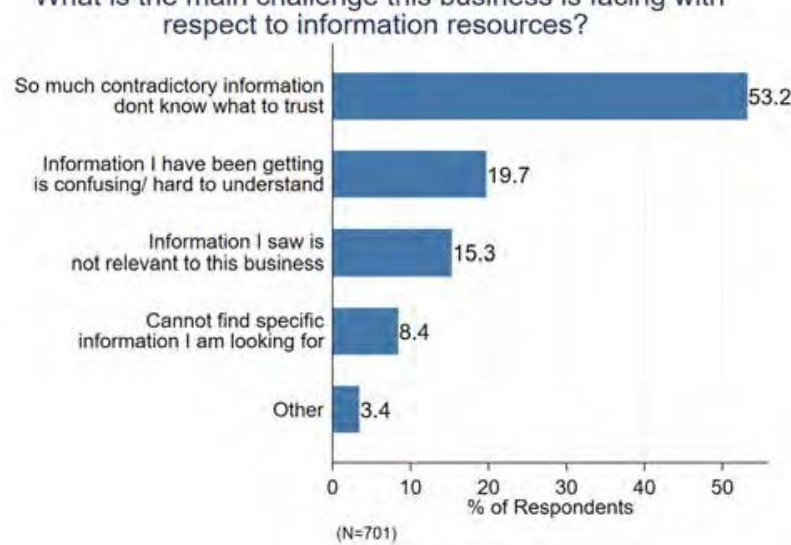

(F) Information Challenges 


\section{Figure 40: Employee/Worker Self-Reported Main Reason for Unemployment}

What is the main reason for your current unemployment?

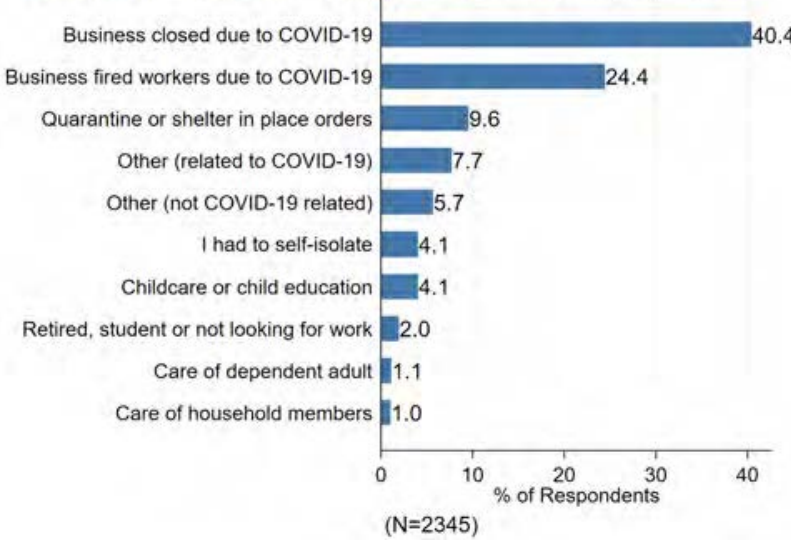

(A) Main Reason
What is the main reason for your current unemployment?

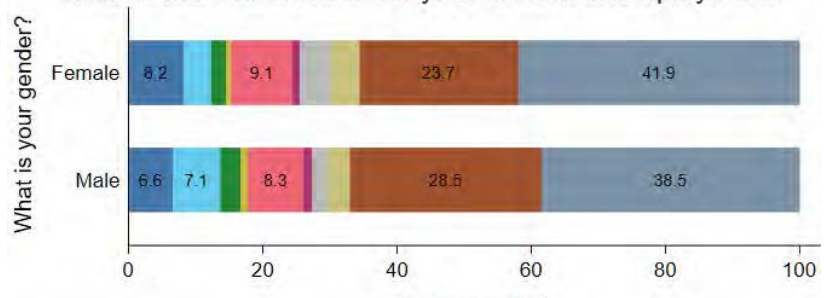

$\%$ of respondents

\begin{tabular}{|l|l|}
\hline Other (related to COVID-19) & Other (not COVID-19 related) \\
Retired, student or not looking for work & Care of household members \\
Quarantine or shelter in place orders & Care of dependent adult \\
Childcare or child education & I had to self-isolate \\
Business fired workers due to CoVID-19 & Business closed due to COVID-19 \\
\hline (n=1572) & \\
\hline
\end{tabular}

(B) Main Reason, by Gender 
Figure 41: Employee/Worker Unemployment Demographics

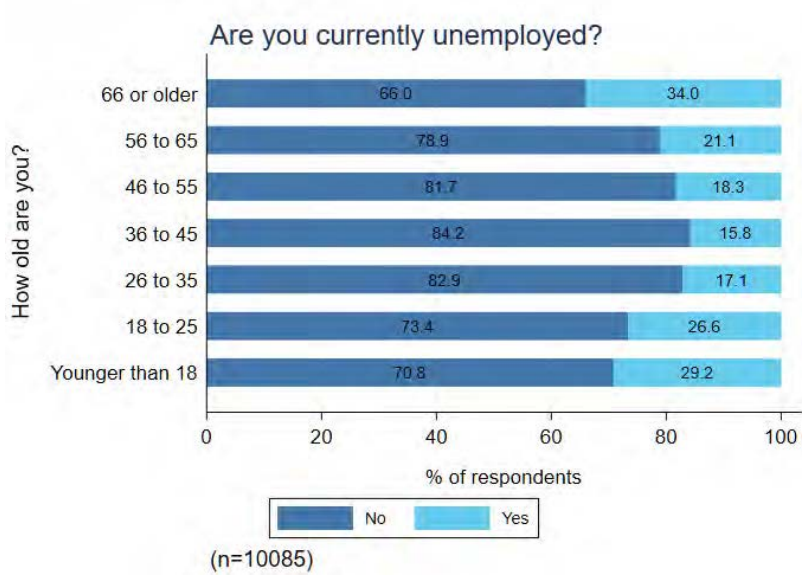

(A) Fraction Unemployed, by Age

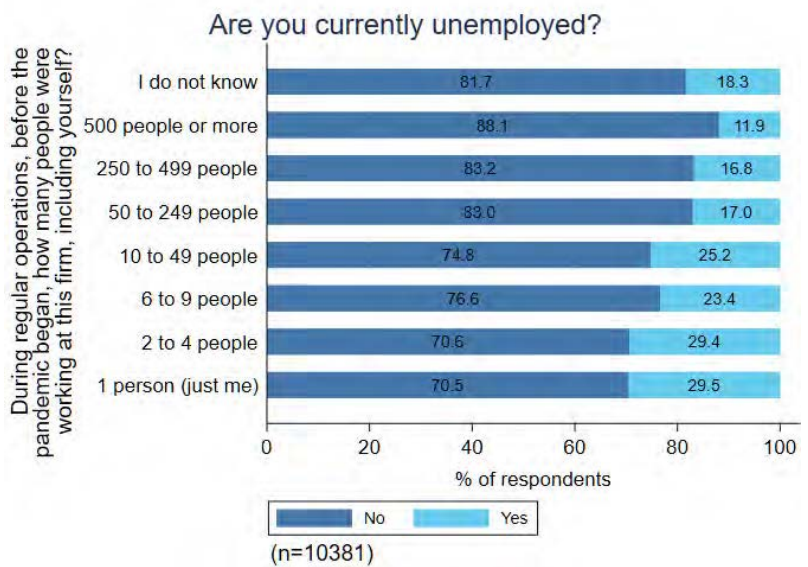

(C) Fraction Unemployed, by Size of Most Recent Company

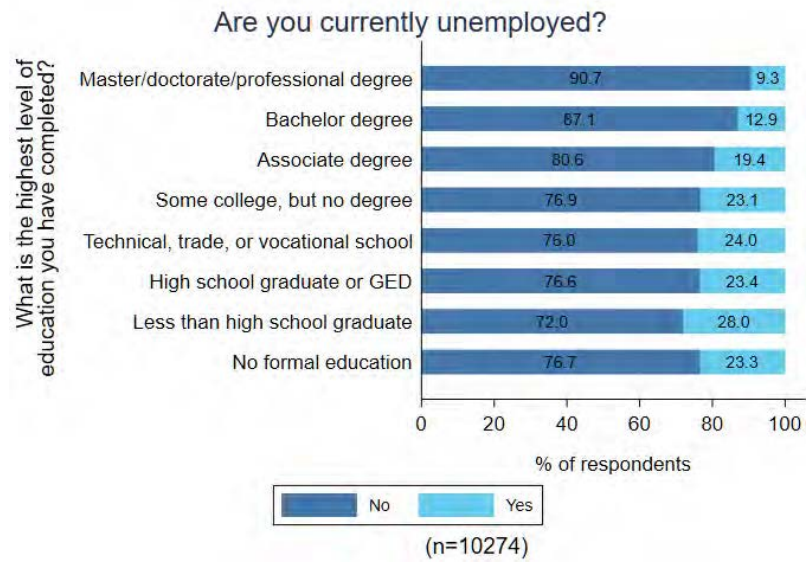

(B) Fraction Unemployed, by Educational Background

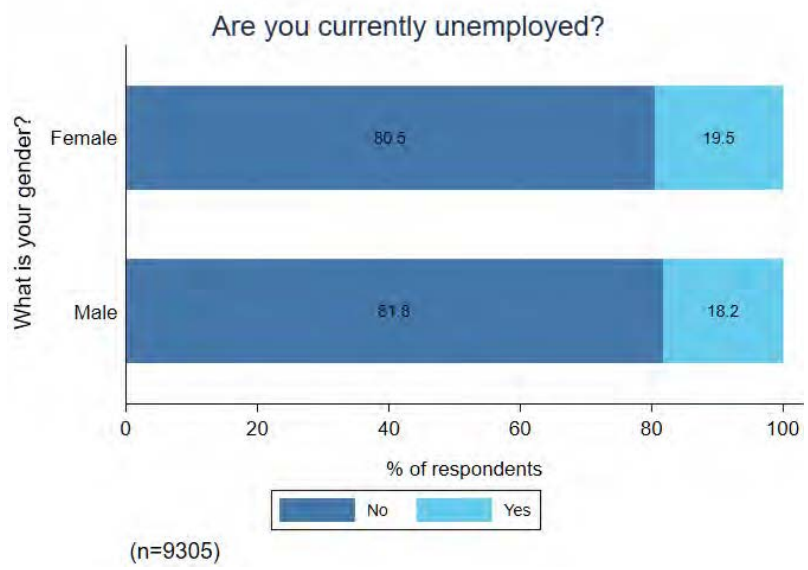

(D) Fraction Unemployed, by Gender

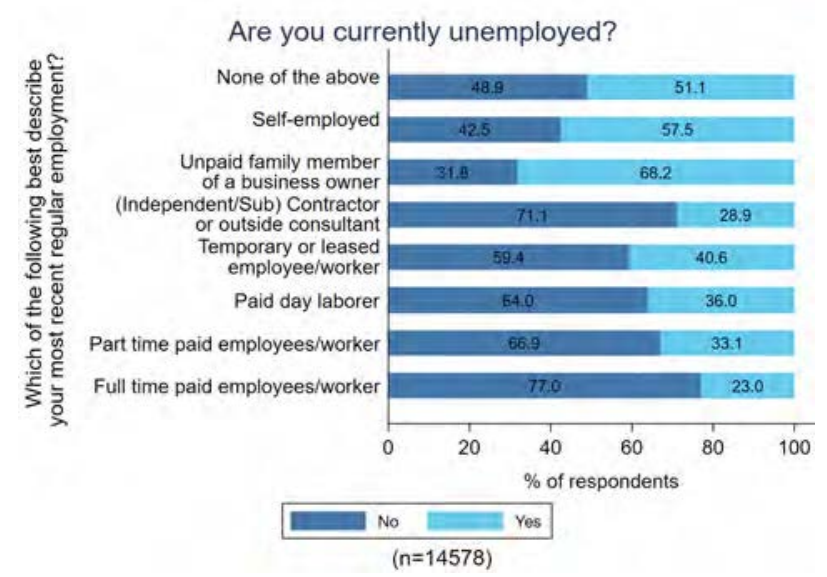

(E) Fraction Unemployed, by Most Regular Employment 
Figure 42: Employee/Activities during Unemployment

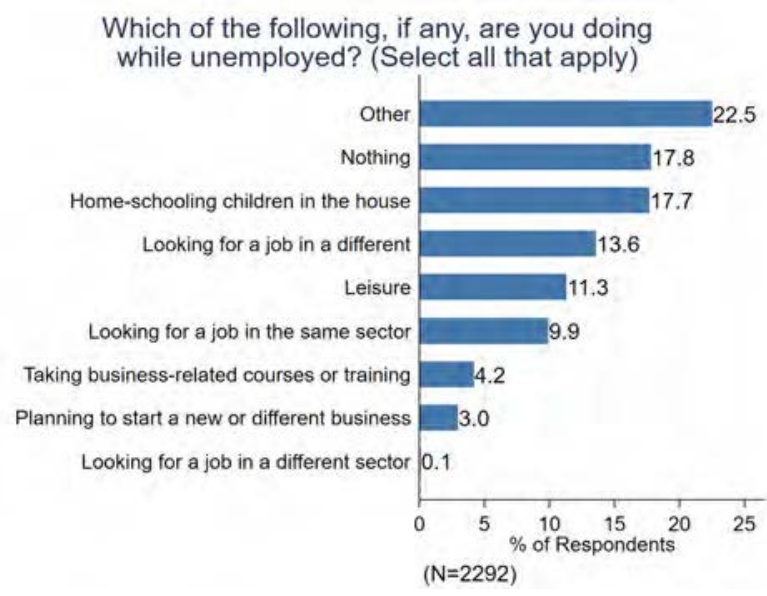

Figure 43: Government/NGO Assistance for Unemployed

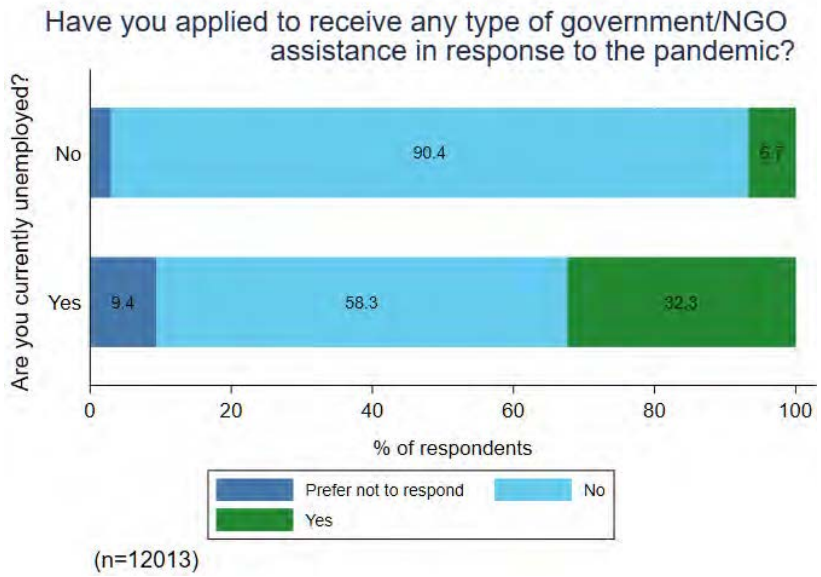

(A) Government/NGO Assistance Applications, by Unemployment Status

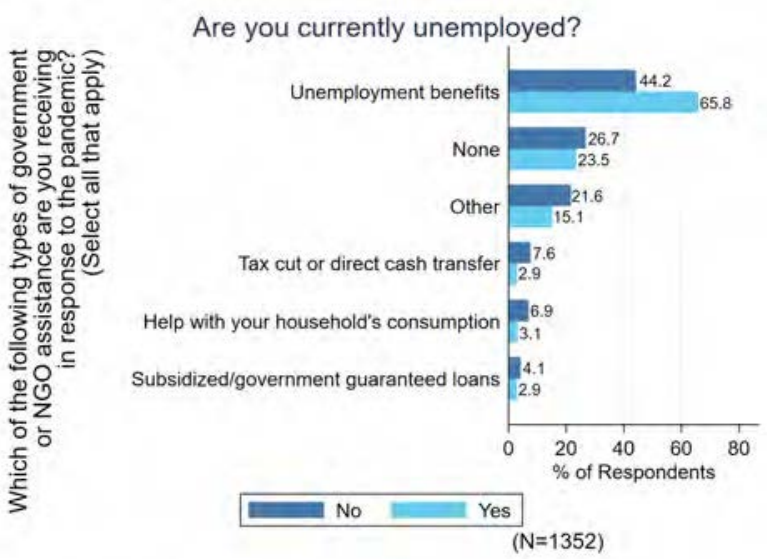

(B) Types of Government Support Receiving, by Unemployment Status

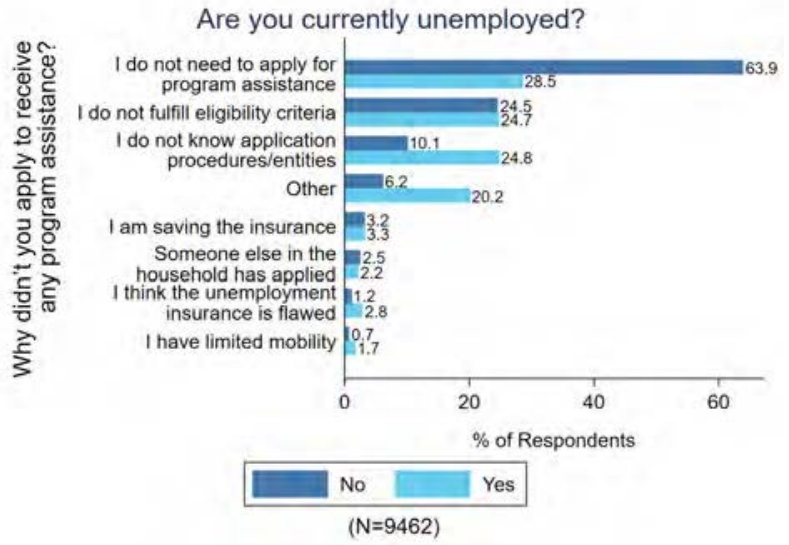

(C) Reasons for not Applying for Government Assistance, by Unemployment Category 
Figure 44: Household Care Responsibilities

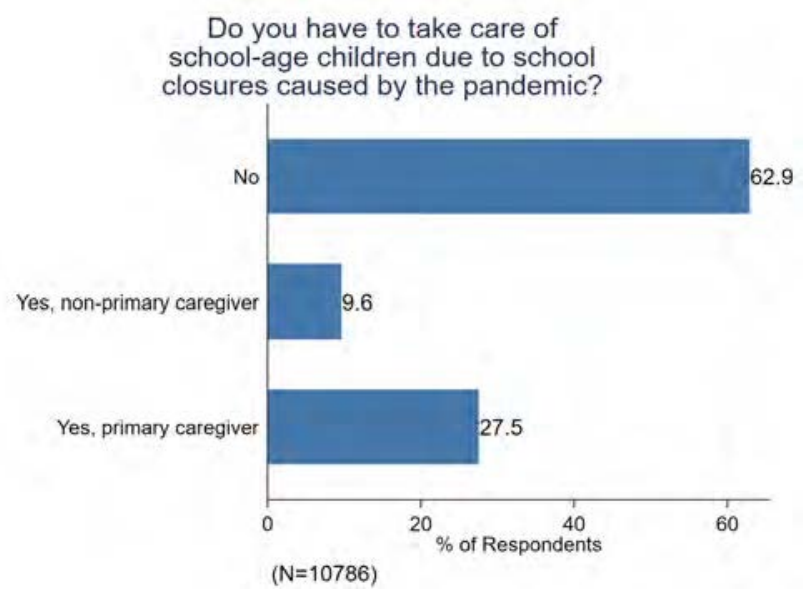

(A) Childcare due to School Closures

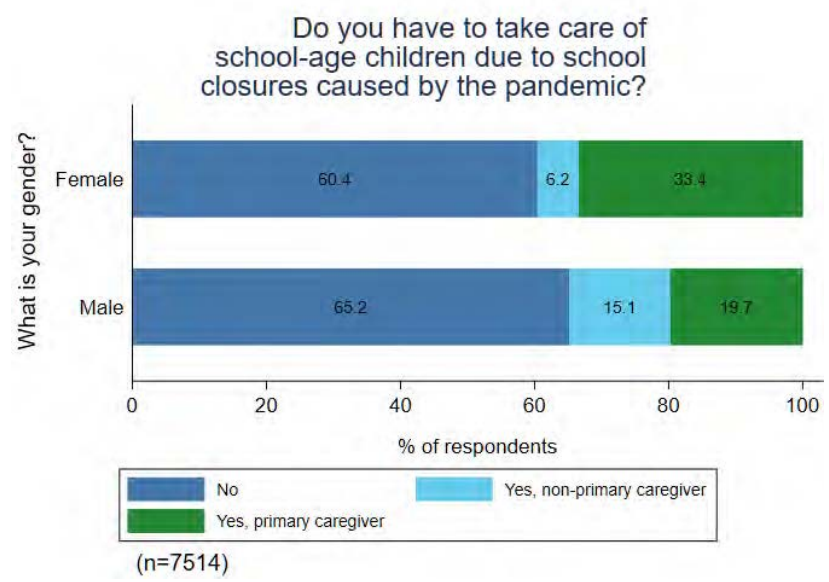

(C) Childcare due to School Closures, by Gender

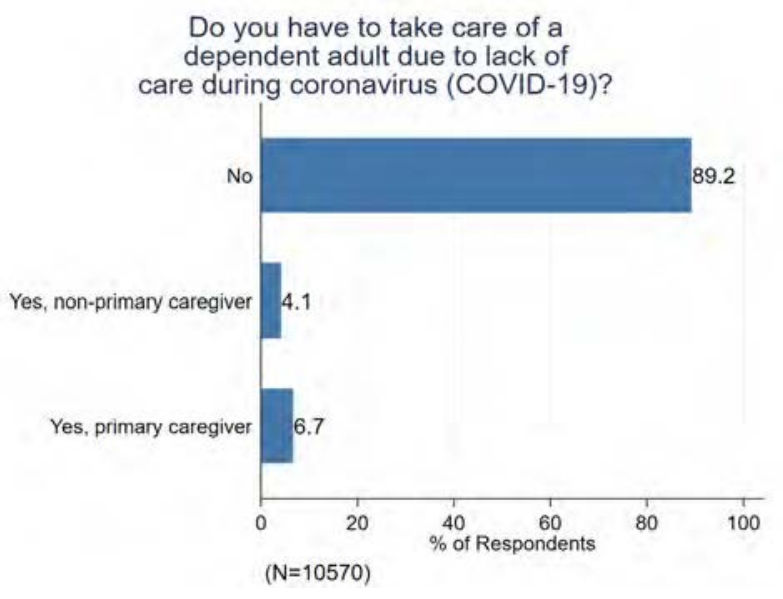

(B) Care of a Dependent Adult

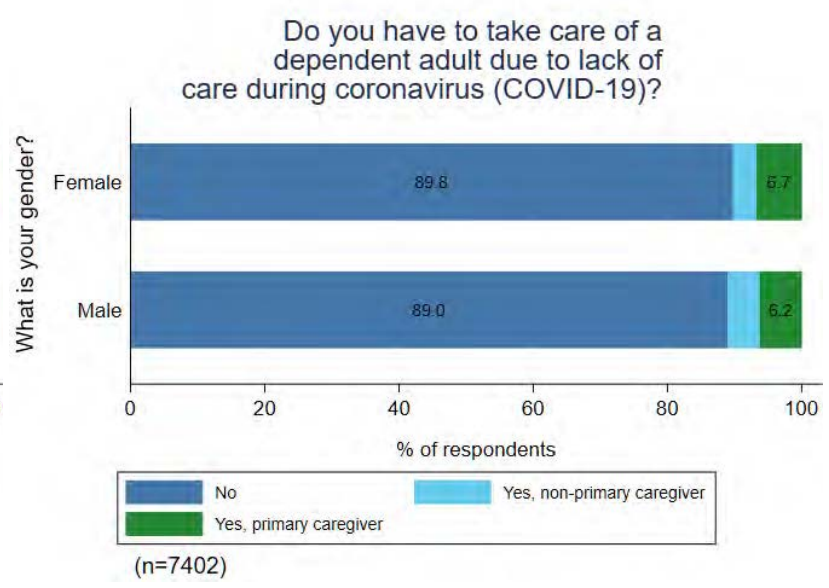

(D) Care of a Dependent Adult, by Gender 


\section{Figure 45: Employee/Worker: Household Impact on Job}

How much have your household responsibilities affected your ability to focus on your work during the pandemic?

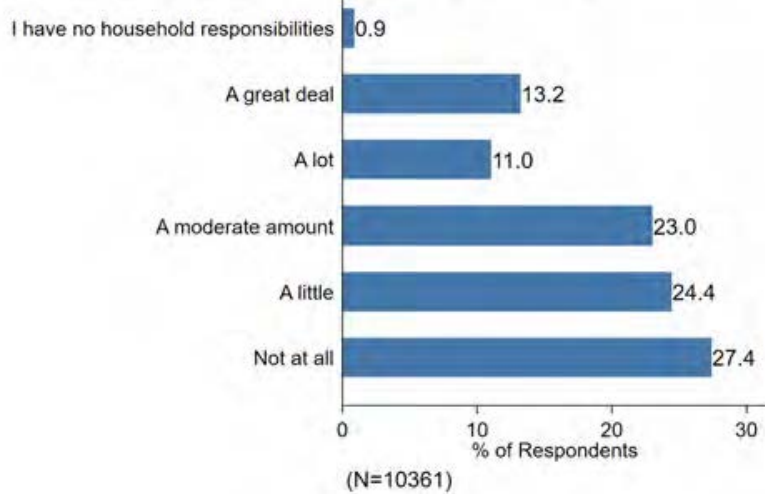

(A) Household Impact on Job

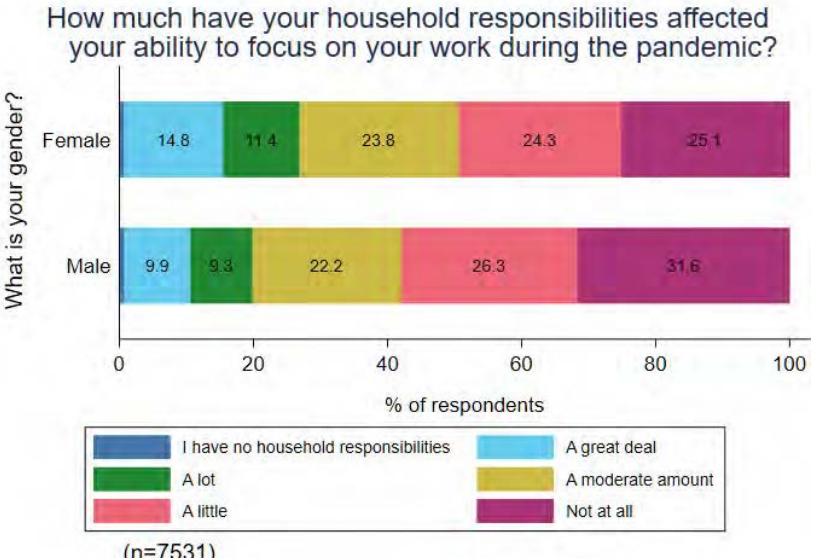

(C) Household Impact on Job, by Gender

How much have your household responsibilities affected your ability to focus on your work during the pandemic?

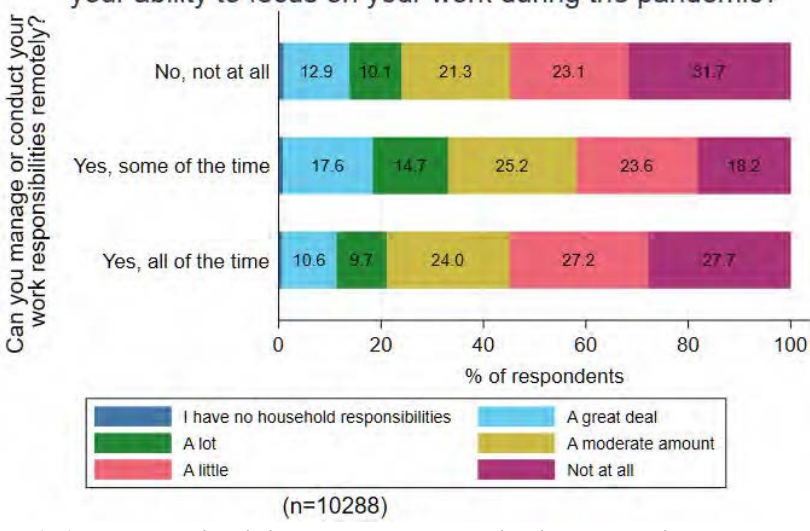

(E) Household Impact on Job, by Work From Home

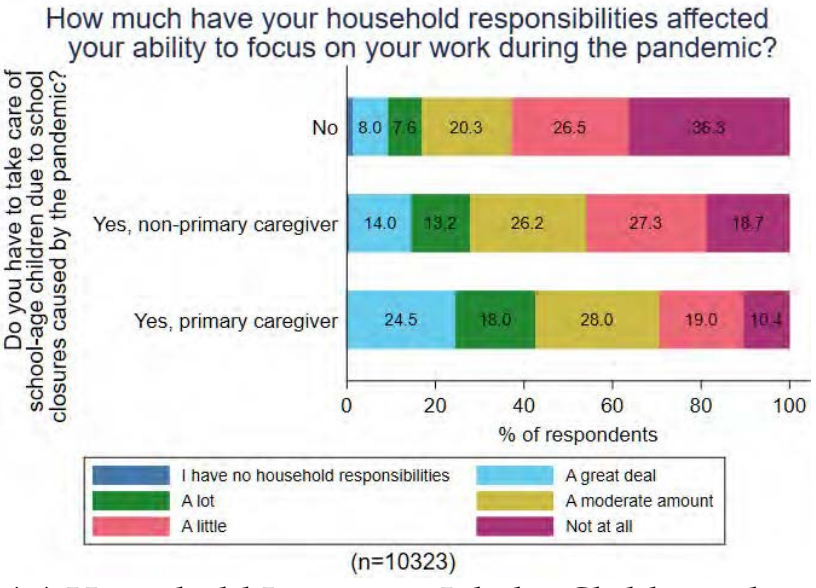

(B) Household Impact on Job, by Childcare due to School Closures

How much have your household responsibilities affected your ability to focus on your work during the pandemic?
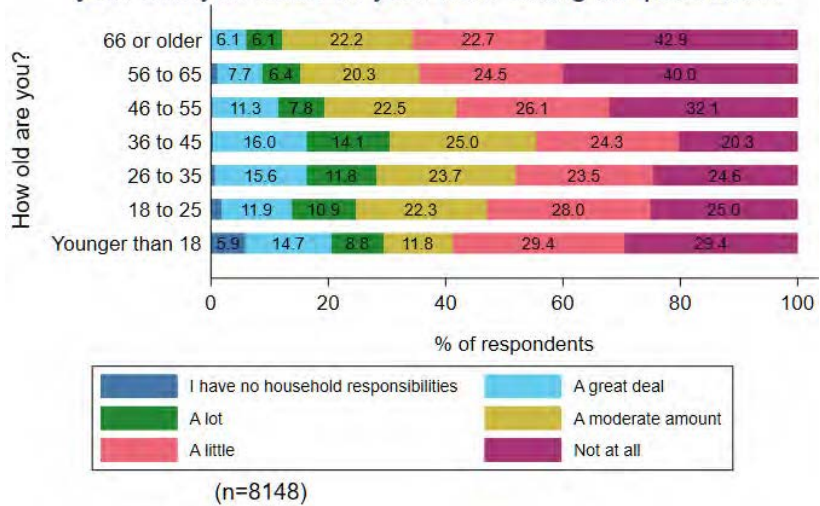

(D) Household Impact on Job, by Age 
Figure 46: Employee/Worker: Job Impact on Household

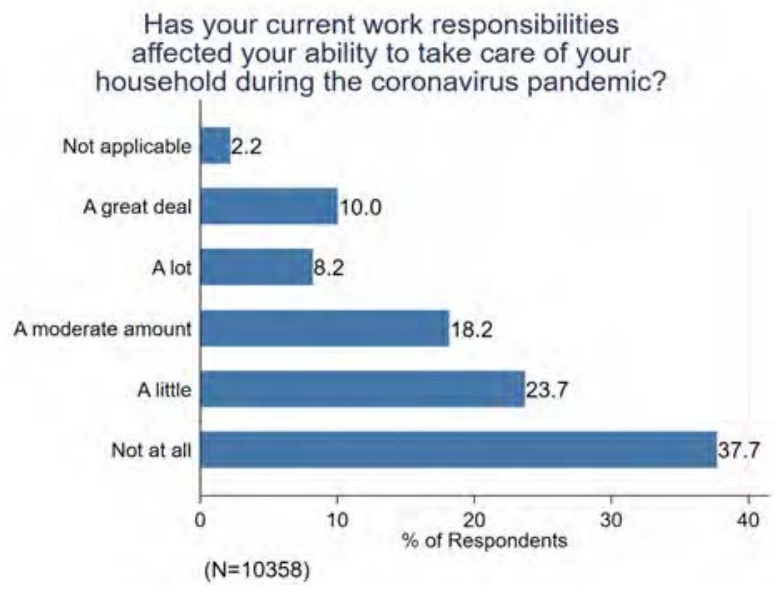

Figure 47: Employee/Worker: Remote Work

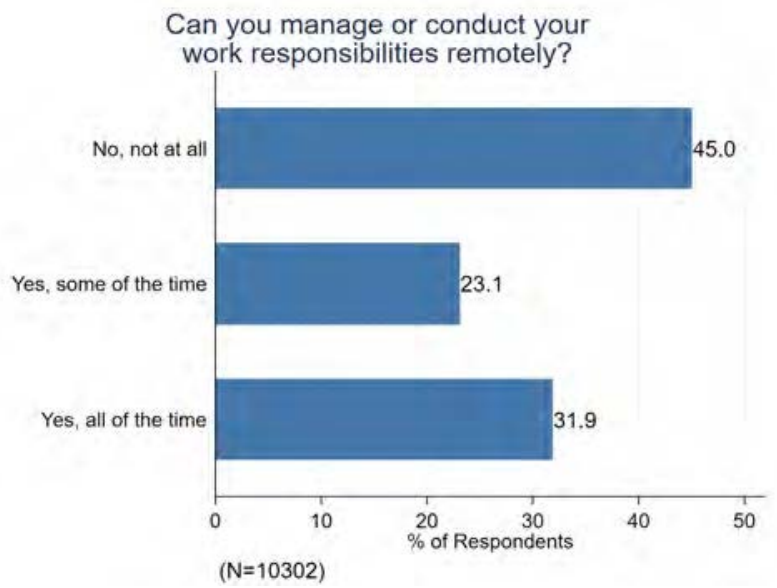

(A) Remote Work

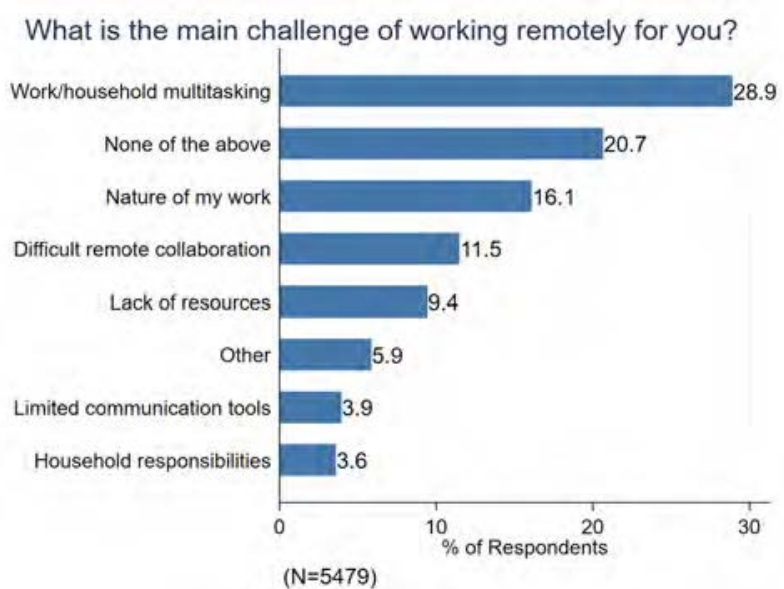

(B) Main Challenge in Working Remotely 
Figure 48: Employee/Worker Remote Work Challenges

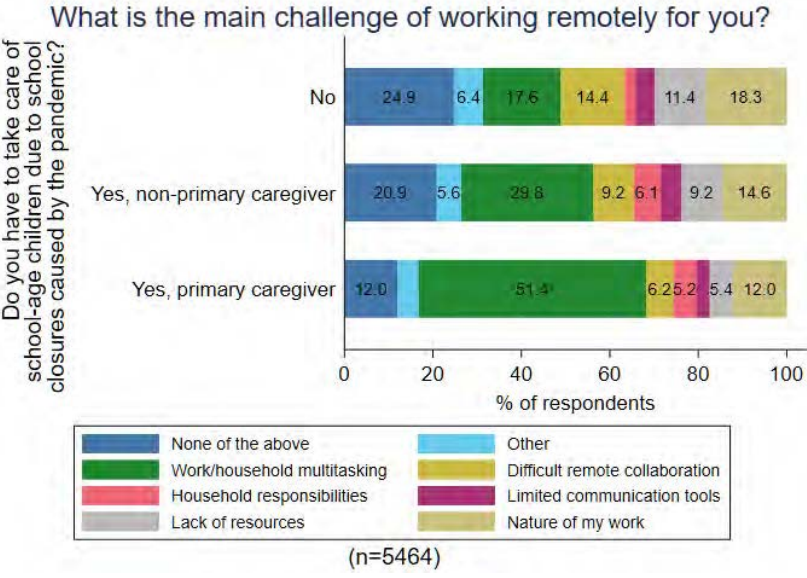

(A) Main Challenge in Working Remotely, by Childcare due to School Closures

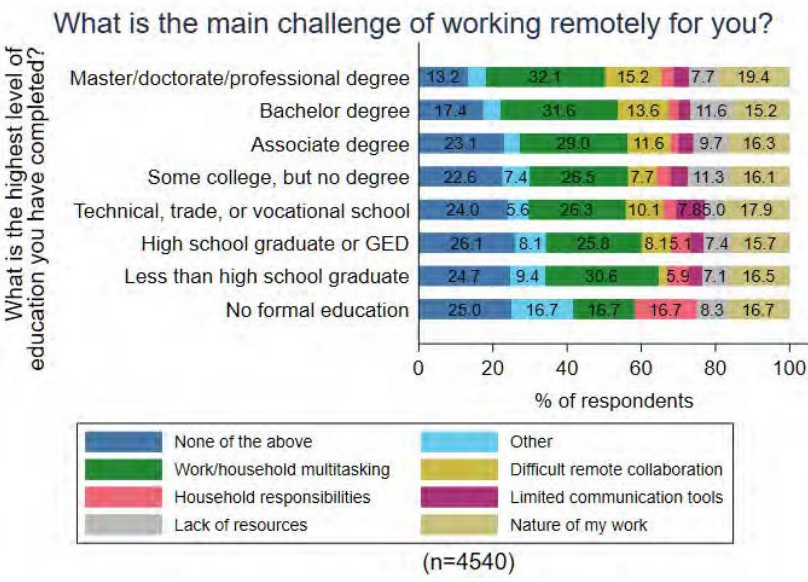

(C) Main Challenge in Working Remotely, by Education

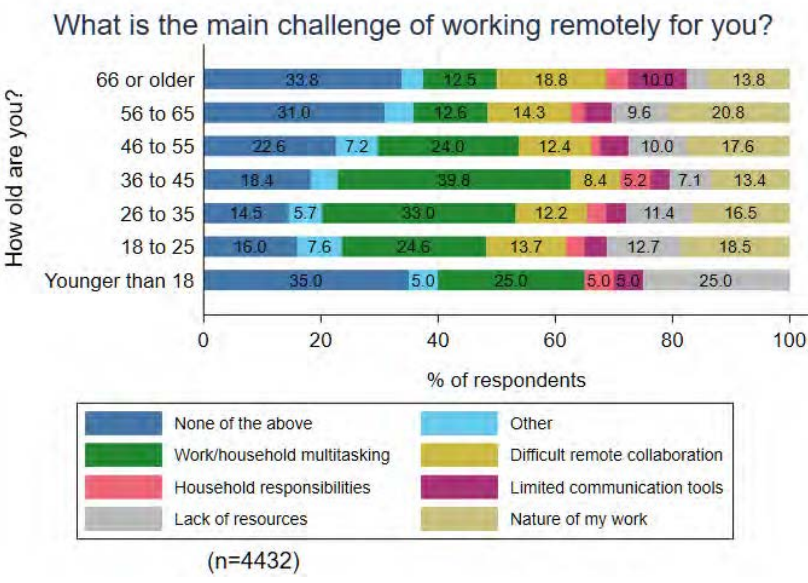

(E) Main Challenge in Working Remotely, by Age

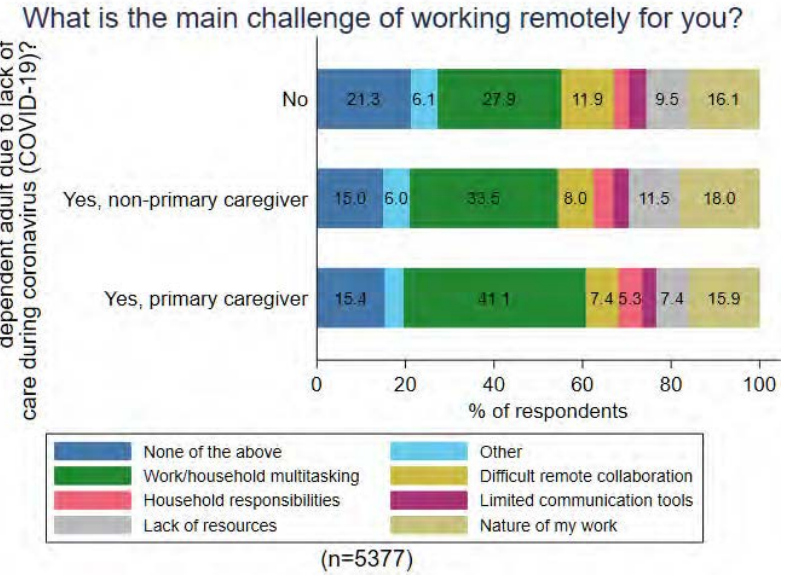

(B) Main Challenge in Working Remotely, by Care for a Dependent Adult

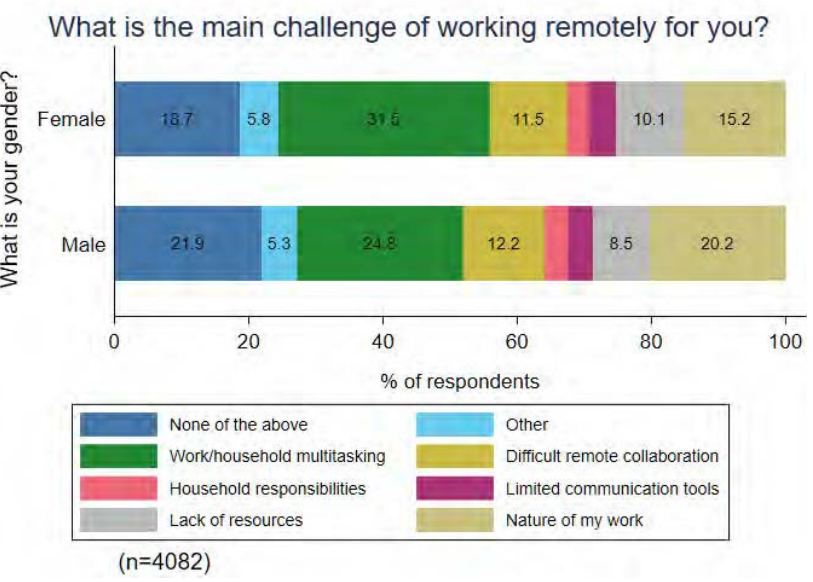

(D) Main Challenge in Working Remotely, by Gender

What is the main challenge of working remotely for you?

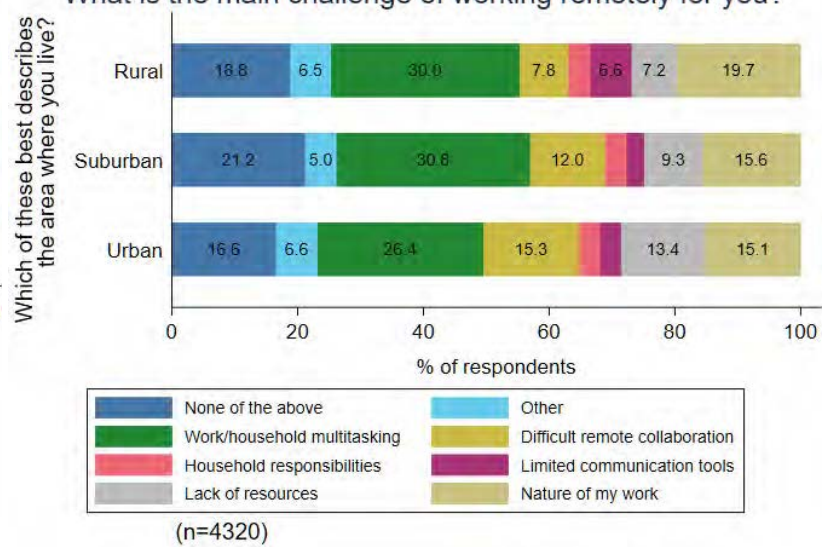

(F) Main Challenge in Working Remotely, by Area 
Figure 49: Employee/Worker: News Sources during the Pandemic

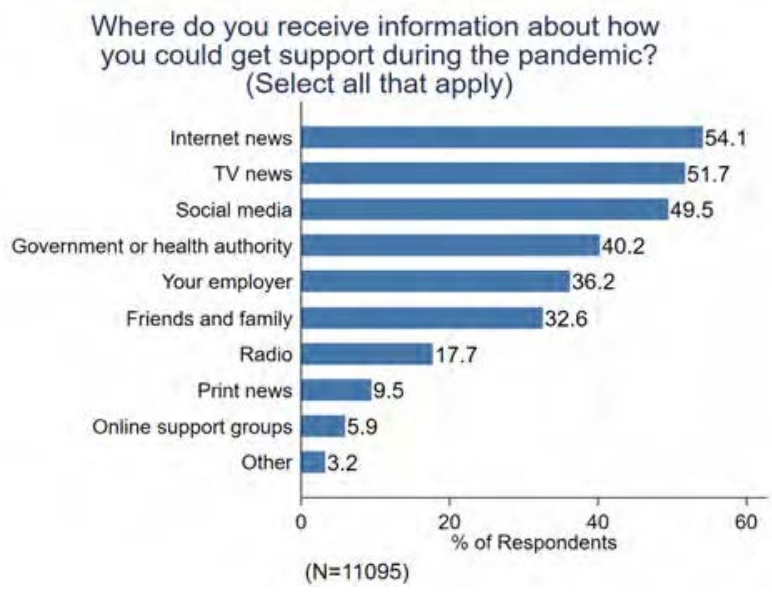




\section{Figure 50: Employee/Worker: Optimism about Future Employment}

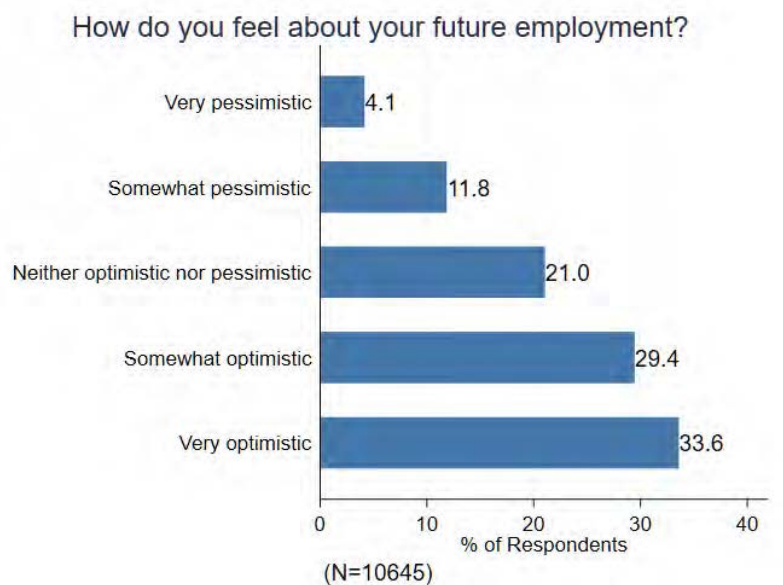

(A) Optimism about Future Employment

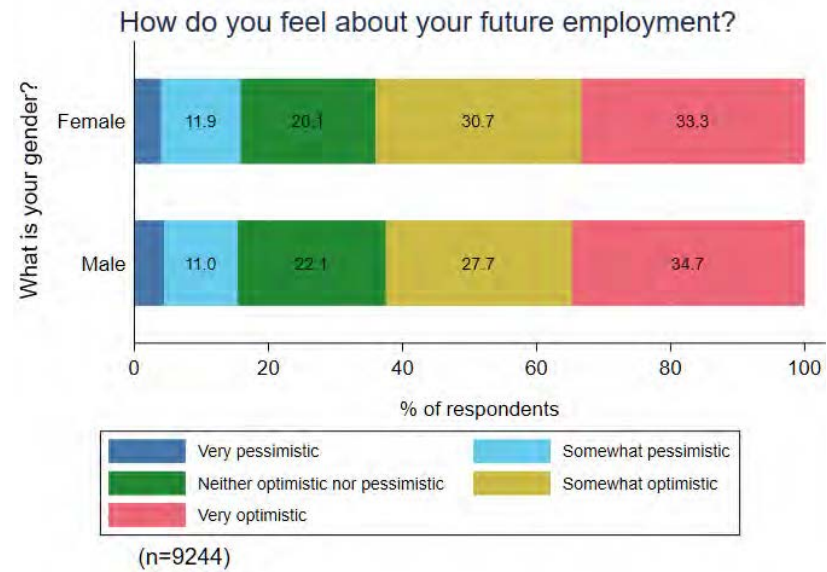

(C) Optimism about Future Employment, by Gender

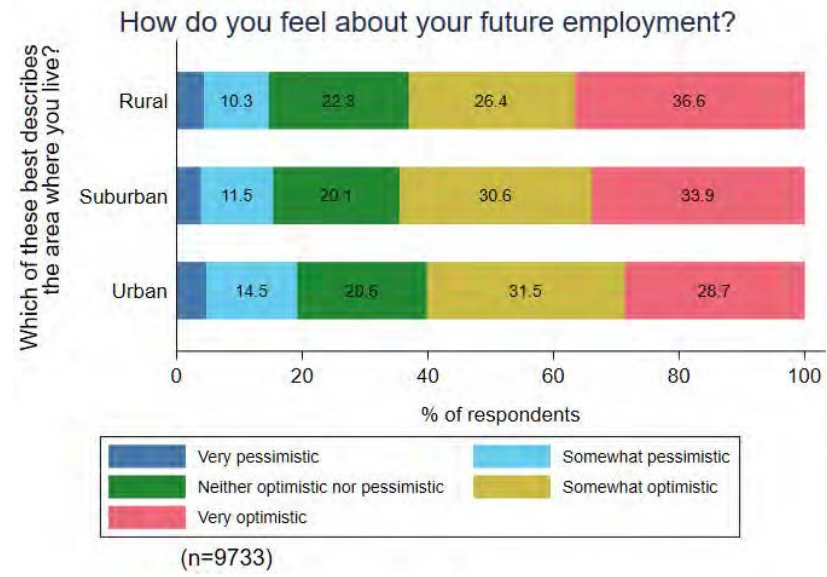

(E) Optimism about Future Employment, by Area

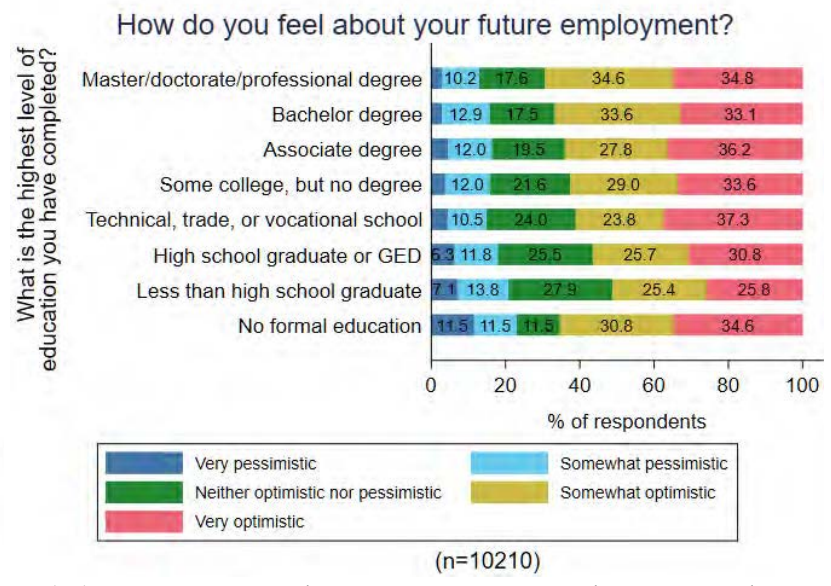

(B) Optimism about Future Employment, by Education

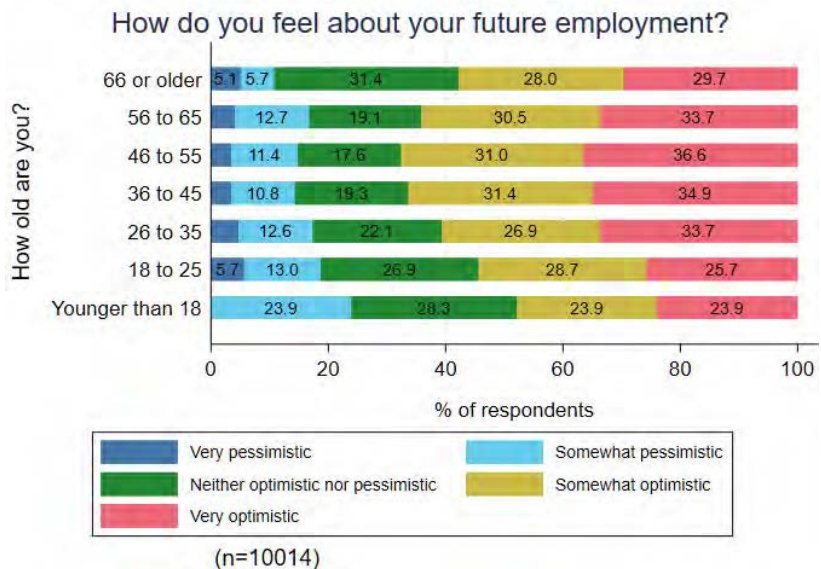

(D) Optimism about Future Employment, by Age

How do you feel about your future employment?

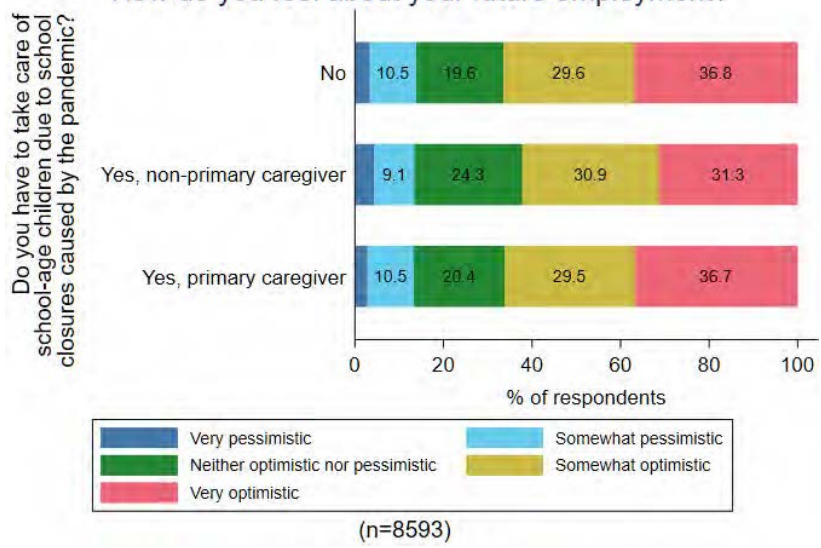

(F) Optimism about Future Employment, by Childcare due to School Closures 


\section{TABLES}

Table 1: Business Demographics vs. Nationwide

(1)

Facebook Sample

\section{Firm Size (Employees) ${ }^{1}$}

1 to 4 people

$55.4 \% \quad 55.8 \%$

5 to 9 people

$13.0 \% \quad 20.0 \%$

10 to 49 people

$15.3 \%$

$19.7 \%$

50 to 249 people

$7.1 \% \quad 3.7 \%$

250 to 499 people

$2.3 \% \quad 0.4 \%$

500 people or more

$6.9 \%$

$0.4 \%$

Firm Location ${ }^{1}$

Urban/Metropolitan

$31.5 \%$

$44.9 \%$

$84.6 \%$

Suburban

$23.6 \%$

N.A.

Rural/Non-Metropolitan

$15.4 \%$

Firm Age ${ }^{1}$

Less than 1 year

$9.9 \% \quad 9.0 \%$

Between 1 and 2 years

$10.5 \% \quad 6.7 \%$

Between 2 and 5 years

$17.3 \%$

$15.6 \%$

5 years or more

$62.2 \% \quad 68.7 \%$

Sector $^{1,2}$

Agriculture, farming, forestry, or mining

$2.5 \%$

$2.9 \%$

Construction

$5.3 \%$

$7.4 \%$

Manufacturing

$2.8 \%$

$4.5 \%$

Retail and wholesale trade

$24.2 \%$

$23.1 \%$

Services

$39.3 \%$

$49.0 \%$

Transportation and logistics

$2.8 \%$

$3.9 \%$

Other

$23.1 \%$

N.A.

\footnotetext{
${ }^{1}$ Data available at https://www. census.gov/programs-surveys/bds/data/data-tables.html.

2 Due to differences between our survey and SIC classification, we aggregated "Hotels, cafes, and restaurants" within "Retail and wholesale trade" and "Information and communication" within "Services".
} 
Table 2: Employee/Worker Demographics vs. Nationwide

(1)

Facebook Sample

US

Basic Demographics ${ }^{1,2}$

Female

Urban

Full vs. Part Time ${ }^{3}$

Full Time

Part Time

Highest Educational Level ${ }^{4}$

No formal education

Less than high school graduate

High school graduate or GED

Some college, no degree

Associate's degree

Bachelor's degree

Technical, trade, or vocational school

Master, doctorate, or professional degree
$63.3 \%$

$71.5 \%$

$58.2 \%$

$80.7 \%$

$81.5 \% \quad 85.7 \%$

$14.0 \% \quad 14.3 \%$

$0.2 \% \quad 0.3 \%$

$2.3 \% \quad 9.6 \%$

$18.2 \% \quad 28.1 \%$

$23.0 \% \quad 15.7 \%$

$11.9 \% \quad 5.9 \%$

$24.0 \% \quad 22.5 \%$

$7.5 \% \quad 4.4 \%$

$12.8 \% \quad 13.5 \%$

$12.0 \% \quad 12.3 \%$

$28.0 \% \quad 22.8 \%$

$23.9 \% \quad 21.0 \%$

$20.8 \% \quad 20.3 \%$

$12.3 \% \quad 17.1 \%$

$3.0 \% \quad 6.6 \%$

$1.5 \% \quad 2.0 \%$

$4.4 \% \quad 7.2 \%$

$6.8 \% \quad 9.3 \%$

$8.5 \% \quad 1.8 \%$

$8.6 \% \quad 10 \%$

$9.3 \% \quad 12.5 \%$

$17.4 \% \quad 12.4 \%$

$6.0 \% \quad 5.7 \%$

$37.4 \% \quad 39.0 \%$

1 Fraction of civilian labor force that is female and 16 or older: https://www.census.gov/quickfacts/ fact/table/US/LFE0 46218. 22010 Census: https: / /www.census.gov/programs-surveys/geography/ guidance/geo-areas/urban-rural/2010-urban-rural.html. Note this is the overall population, not the population of the labor force. 3 Employee CPS April 2020: https://www.bls.gov/web/empsit/ cpseea06.htm. The Facebook numbers do not sum to $100 \%$ since there were other options with low response rates (e.g. "Paid day laborer"). 4 Nationwide data from the CPS Annual Social and Economic Supplement, 2012: https://www.census.gov/content/census/en/data/tables/2019/demo/ educational-attainment/cps-detailed-tables.html. We restrict to respondents aged 26 and older to ensure comparatibility. ${ }^{5}$ CPS: https://www.bls.gov/cps/cpsaat18b.htm. The CPS age buckets are listed in parentheses, due to slight differences. ${ }^{6}$ CPS: https://www.bls.gov/cps/cpsaat 18b.htm. 


\section{Table 3: Open Businesses}

This table looks at how businesses' operational status varies by firm and owner characteristics. The dependent variable takes a value of one if the respondent replied yes to "Is this business currently operational or engaging in any revenue-generating activities?". Age is the time since the business opened, industry is the self-reported industry of the business, sales is the total revenues of the business in 2019, in-person interactions captures the share of the business's interactions between customers and employees that need to be conducted in the same physical location, and male-owned or managed takes a value of one if the gender of the business owner or manager (respondent) is male. The omitted base groups are age - less than 1 year, industry - agriculture or mining, sales - business not operational in 2019, in-person interactions - more than half of the interactions are in-person, and gender - female-owned or managed.

\begin{tabular}{|c|c|c|c|c|c|c|}
\hline & \multicolumn{6}{|c|}{ Business Operational } \\
\hline & (1) & (2) & (3) & (4) & (5) & (6) \\
\hline Age - Between 1 and 2 years & $\begin{array}{l}0.024^{*} \\
(0.013)\end{array}$ & & & & & $\begin{array}{l}-0.006 \\
(0.014)\end{array}$ \\
\hline Age - Between 2 and 5 years & $\begin{array}{c}0.065^{* * *} \\
(0.011)\end{array}$ & & & & & $\begin{array}{l}-0.000 \\
(0.013)\end{array}$ \\
\hline Age - 5 years or more & $\begin{array}{c}0.120^{* * *} \\
(0.010)\end{array}$ & & & & & $\begin{array}{c}0.007 \\
(0.012)\end{array}$ \\
\hline Construction & & $\begin{array}{l}-0.030 \\
(0.019)\end{array}$ & & & & $\begin{array}{c}-0.108^{* * *} \\
(0.020)\end{array}$ \\
\hline Hotels, cafes, and restaurants & & $\begin{array}{l}-0.201^{* * *} \\
(0.019)\end{array}$ & & & & $\begin{array}{c}-0.193^{* * *} \\
(0.020)\end{array}$ \\
\hline Information and communication & & $\begin{array}{l}0.034^{*} \\
(0.018)\end{array}$ & & & & $\begin{array}{l}-0.057^{* * *} \\
(0.019)\end{array}$ \\
\hline Manufacturing & & $\begin{array}{l}0.038^{*} \\
(0.021)\end{array}$ & & & & $\begin{array}{l}-0.068^{* * *} \\
(0.022)\end{array}$ \\
\hline Other & & $\begin{array}{l}-0.150^{* * *} \\
(0.017)\end{array}$ & & & & $\begin{array}{l}-0.179^{* * *} \\
(0.018)\end{array}$ \\
\hline Retail and wholesale trade & & $\begin{array}{l}-0.043^{* *} \\
(0.017)\end{array}$ & & & & $\begin{array}{l}-0.055^{* * *} \\
(0.018)\end{array}$ \\
\hline Services & & $\begin{array}{l}-0.173^{* * *} \\
(0.016)\end{array}$ & & & & $\begin{array}{c}-0.180^{* * *} \\
(0.017)\end{array}$ \\
\hline Transportation and logistics & & $\begin{array}{l}-0.067^{* * *} \\
(0.022)\end{array}$ & & & & $\begin{array}{c}-0.127^{* * *} \\
(0.023)\end{array}$ \\
\hline Sales less than $\$ 50,000$ & & & $\begin{array}{l}0.008 \\
(0.015)\end{array}$ & & & $\begin{array}{c}0.020 \\
(0.018)\end{array}$ \\
\hline Sales between $\$ 50,000$ - $\$ 999,999$ & & & $\begin{array}{l}0.136^{* * *} \\
(0.015)\end{array}$ & & & $\begin{array}{l}0.174^{* * *} \\
(0.019)\end{array}$ \\
\hline Sales $\$ 1,000,000$ or more & & & $\begin{array}{c}0.280^{* * *} \\
(0.016)\end{array}$ & & & $\begin{array}{l}0.308^{* * *} \\
(0.019)\end{array}$ \\
\hline $\begin{array}{l}\text { In-person interactions - Half } \\
\text { or less }\end{array}$ & & & & $\begin{array}{c}0.214^{* * *} \\
(0.005)\end{array}$ & & $\begin{array}{l}0.229^{* * *} \\
(0.006)\end{array}$ \\
\hline Male-owned or managed & & & & & $\begin{array}{c}0.064^{* * *} \\
(0.006)\end{array}$ & $\begin{array}{l}0.021^{* * *} \\
(0.006)\end{array}$ \\
\hline Obs. & 30,511 & 31,056 & 27,552 & 31,072 & 28,198 & 25,705 \\
\hline$R^{2}$ & 0.008 & 0.025 & 0.045 & 0.050 & 0.004 & 0.124 \\
\hline
\end{tabular}




\section{Table 4: Business Optimism}

This table looks at how business optimism varies by firm and owner characteristics. The dependent variable takes a value of one if the respondent replied "Extremely Optimistic" or "Somewhat Optimistic" to "How do you feel about the future of this business?". Open takes a value of one if the business is operational as of the time of the survey. The omitted base groups are age - less than 1 year, industry - agriculture or mining, sales - business not operational in 2019, in-person interactions - more than half of the interactions are in-person, and gender - female-owned or managed. Other variables are as defined in Table 3.

\begin{tabular}{|c|c|c|c|c|c|c|c|}
\hline & \multicolumn{7}{|c|}{ Optimistic } \\
\hline & (1) & (2) & (3) & (4) & (5) & (6) & (7) \\
\hline Open & $\begin{array}{l}0.085^{* * * *} \\
(0.006)\end{array}$ & & & & & & $\begin{array}{l}0.071^{* * *} \\
(0.007)\end{array}$ \\
\hline Age - Between 1 and 2 years & & $\begin{array}{l}-0.019 \\
(0.013)\end{array}$ & & & & & $\begin{array}{l}-0.022 \\
(0.014)\end{array}$ \\
\hline Age - Between 2 and 5 years & & $\begin{array}{c}-0.039 * * * \\
(0.011)\end{array}$ & & & & & $\begin{array}{l}-0.045^{* * * *} \\
(0.014)\end{array}$ \\
\hline Age - 5 years or more & & $\begin{array}{l}-0.041^{* * *} \\
(0.010)\end{array}$ & & & & & $\begin{array}{l}-0.069^{* * *} \\
(0.013)\end{array}$ \\
\hline Construction & & & $\begin{array}{c}0.034 \\
(0.022)\end{array}$ & & & & $\begin{array}{l}0.041^{*} \\
(0.024)\end{array}$ \\
\hline Hotels, cafes, and restaurants & & & $\begin{array}{l}-0.069^{* * *} \\
(0.021)\end{array}$ & & & & $\begin{array}{c}-0.046^{* *} \\
(0.023)\end{array}$ \\
\hline Information and communication & & & $\begin{array}{l}0.045^{* *} \\
(0.022)\end{array}$ & & & & $\begin{array}{l}0.040^{*} \\
(0.023)\end{array}$ \\
\hline Manufacturing & & & $\begin{array}{c}0.001 \\
(0.025)\end{array}$ & & & & $\begin{array}{l}-0.030 \\
(0.027)\end{array}$ \\
\hline Other & & & $\begin{array}{c}0.020 \\
(0.019)\end{array}$ & & & & $\begin{array}{c}0.032 \\
(0.020)\end{array}$ \\
\hline Retail and wholesale trade & & & $\begin{array}{l}-0.012 \\
(0.020)\end{array}$ & & & & $\begin{array}{l}-0.011 \\
(0.021)\end{array}$ \\
\hline Services & & & $\begin{array}{c}0.019 \\
(0.019)\end{array}$ & & & & $\begin{array}{l}0.041^{* *} \\
(0.020)\end{array}$ \\
\hline Transportation and logistics & & & $\begin{array}{l}-0.029 \\
(0.025)\end{array}$ & & & & $\begin{array}{l}-0.022 \\
(0.027)\end{array}$ \\
\hline Sales less than $\$ 50,000$ & & & & $\begin{array}{l}-0.053^{* * *} \\
(0.015)\end{array}$ & & & $\begin{array}{l}-0.024 \\
(0.018)\end{array}$ \\
\hline Sales between $\$ 50,000$ - $\$ 999,999$ & & & & $\begin{array}{l}-0.068^{* * *} \\
(0.015)\end{array}$ & & & $\begin{array}{l}-0.025 \\
(0.019)\end{array}$ \\
\hline Sales $\$ 1,000,000$ or more & & & & $\begin{array}{c}0.008 \\
(0.016)\end{array}$ & & & $\begin{array}{l}0.057^{* * *} \\
(0.020)\end{array}$ \\
\hline $\begin{array}{l}\text { In-person interactions - Half } \\
\text { or less }\end{array}$ & & & & & $\begin{array}{c}0.065^{* * *} \\
(0.006)\end{array}$ & & $\begin{array}{l}0.041^{* * *} \\
(0.007)\end{array}$ \\
\hline Male-owned or managed & & & & & & $\begin{array}{l}-0.007 \\
(0.006)\end{array}$ & $\begin{array}{l}-0.010^{*} \\
(0.006)\end{array}$ \\
\hline $\begin{array}{l}\text { Obs. } \\
R^{2}\end{array}$ & $\begin{array}{c}29,069 \\
0.007\end{array}$ & $\begin{array}{c}29,048 \\
0.001\end{array}$ & $\begin{array}{c}28,926 \\
0.003\end{array}$ & $\begin{array}{c}27,081 \\
0.004\end{array}$ & $\begin{array}{c}28,943 \\
0.004\end{array}$ & $\begin{array}{c}28,116 \\
0.000\end{array}$ & $\begin{array}{c}25,623 \\
0.017\end{array}$ \\
\hline
\end{tabular}




\section{Table 5: Biggest Challenge}

This table looks at how business challenges vary by firm and owner characteristics. Businesses were asked "What do you expect this business's biggest challenge to be in the next few months?". The dependent variable takes a value of one if the response is "Cash flow" (Column 1), "Lack of demand" (Column 2), "Government or health authority orders" (Column 3), "Logistics (e.g. shipping, delivering services or goods)" (Column 4), "Finding supplies" (Column 5), or "Lack of staff" (Column 6). The omitted base groups are age - less than 1 year, industry - agriculture or mining, sales business not operational in 2019, in-person interactions - more than half of the interactions are in-person, and gender - female-owned or managed. Other variables are as defined in Table 3.

\begin{tabular}{|c|c|c|c|c|c|c|}
\hline & $\begin{array}{c}\text { (1) } \\
\text { Cash flow }\end{array}$ & $\begin{array}{c}(2) \\
\text { Lack of } \\
\text { demand }\end{array}$ & $\begin{array}{c}\text { (3) } \\
\text { Government } \\
\text { orders }\end{array}$ & $\begin{array}{c}(4) \\
\text { Logistics } \\
\end{array}$ & $\begin{array}{c}(5) \\
\text { Finding } \\
\text { supplies }\end{array}$ & $\begin{array}{c}(6) \\
\text { Lack of } \\
\text { staff }\end{array}$ \\
\hline Age - Between 1 and 2 years & $\begin{array}{c}0.004 \\
(0.018)\end{array}$ & $\begin{array}{c}-0.022 \\
(0.017)\end{array}$ & $\begin{array}{c}0.012 \\
(0.011)\end{array}$ & $\begin{array}{c}0.005 \\
(0.010)\end{array}$ & $\begin{array}{l}-0.010 \\
(0.009)\end{array}$ & $\begin{array}{l}-0.005 \\
(0.006)\end{array}$ \\
\hline Age - Between 2 and 5 years & $\begin{array}{c}0.006 \\
(0.017)\end{array}$ & $\begin{array}{l}-0.005 \\
(0.016)\end{array}$ & $\begin{array}{c}0.003 \\
(0.010)\end{array}$ & $\begin{array}{l}-0.003 \\
(0.009)\end{array}$ & $\begin{array}{l}-0.012 \\
(0.009)\end{array}$ & $\begin{array}{l}-0.005 \\
(0.006)\end{array}$ \\
\hline Age - 5 years or more & $\begin{array}{l}-0.004 \\
(0.016)\end{array}$ & $\begin{array}{c}-0.025^{*} \\
(0.015)\end{array}$ & $\begin{array}{l}0.023^{* *} \\
(0.010)\end{array}$ & $\begin{array}{l}-0.007 \\
(0.008)\end{array}$ & $\begin{array}{l}-0.006 \\
(0.008)\end{array}$ & $\begin{array}{c}0.001 \\
(0.005)\end{array}$ \\
\hline Construction & $\begin{array}{c}0.016 \\
(0.024)\end{array}$ & $\begin{array}{c}0.076^{* * *} \\
(0.022)\end{array}$ & $\begin{array}{c}0.026 \\
(0.018)\end{array}$ & $\begin{array}{c}-0.046^{* * *} \\
(0.015)\end{array}$ & $\begin{array}{c}0.003 \\
(0.013)\end{array}$ & $\begin{array}{c}0.003 \\
(0.011)\end{array}$ \\
\hline Hotels, cafes, and restaurants & $\begin{array}{c}0.086^{* * *} \\
(0.024)\end{array}$ & $\begin{array}{c}0.015 \\
(0.021)\end{array}$ & $\begin{array}{l}0.045^{* *} \\
(0.018)\end{array}$ & $\begin{array}{c}-0.057^{* * *} \\
(0.014)\end{array}$ & $\begin{array}{l}-0.009 \\
(0.012)\end{array}$ & $\begin{array}{l}0.023^{* *} \\
(0.011)\end{array}$ \\
\hline Information and communication & $\begin{array}{c}0.122^{* * *} \\
(0.024)\end{array}$ & $\begin{array}{l}0.042^{* *} \\
(0.021)\end{array}$ & $\begin{array}{l}-0.009 \\
(0.016)\end{array}$ & $\begin{array}{c}-0.048^{* * *} \\
(0.015)\end{array}$ & $\begin{array}{c}-0.038^{* * *} \\
(0.011)\end{array}$ & $\begin{array}{c}0.004 \\
(0.010)\end{array}$ \\
\hline Manufacturing & $\begin{array}{l}-0.010 \\
(0.026)\end{array}$ & $\begin{array}{c}0.107^{* * *} \\
(0.026)\end{array}$ & $\begin{array}{l}-0.026 \\
(0.018)\end{array}$ & $\begin{array}{l}-0.017 \\
(0.018)\end{array}$ & $\begin{array}{c}0.044^{* * *} \\
(0.016)\end{array}$ & $\begin{array}{l}-0.002 \\
(0.012)\end{array}$ \\
\hline Other & $\begin{array}{l}0.051^{* *} \\
(0.021)\end{array}$ & $\begin{array}{c}0.010 \\
(0.019)\end{array}$ & $\begin{array}{c}0.040^{* * *} \\
(0.015)\end{array}$ & $\begin{array}{c}-0.060^{* * *} \\
(0.014)\end{array}$ & $\begin{array}{l}-0.010 \\
(0.011)\end{array}$ & $\begin{array}{l}-0.014 \\
(0.009)\end{array}$ \\
\hline Retail and wholesale trade & $\begin{array}{c}0.028 \\
(0.021)\end{array}$ & $\begin{array}{c}0.021 \\
(0.019)\end{array}$ & $\begin{array}{l}-0.004 \\
(0.015)\end{array}$ & $\begin{array}{l}-0.008 \\
(0.014)\end{array}$ & $\begin{array}{c}0.011 \\
(0.011)\end{array}$ & $\begin{array}{c}0.004 \\
(0.009)\end{array}$ \\
\hline Services & $\begin{array}{c}0.085^{* * *} \\
(0.021)\end{array}$ & $\begin{array}{l}0.046^{* *} \\
(0.019)\end{array}$ & $\begin{array}{c}0.023 \\
(0.014)\end{array}$ & $\begin{array}{c}-0.064^{* * *} \\
(0.014)\end{array}$ & $\begin{array}{c}-0.019 * \\
(0.011)\end{array}$ & $\begin{array}{c}0.000 \\
(0.009)\end{array}$ \\
\hline Transportation and logistics & $\begin{array}{l}-0.002 \\
(0.027)\end{array}$ & $\begin{array}{l}0.056^{* *} \\
(0.026)\end{array}$ & $\begin{array}{c}0.002 \\
(0.020)\end{array}$ & $\begin{array}{c}0.011 \\
(0.019)\end{array}$ & $\begin{array}{c}0.003 \\
(0.014)\end{array}$ & $\begin{array}{c}-0.008 \\
(0.012)\end{array}$ \\
\hline Sales less than $\$ 50,000$ & $\begin{array}{l}0.049^{* *} \\
(0.022)\end{array}$ & $\begin{array}{c}0.033 \\
(0.022)\end{array}$ & $\begin{array}{l}-0.013 \\
(0.014)\end{array}$ & $\begin{array}{c}0.005 \\
(0.012)\end{array}$ & $\begin{array}{l}-0.006 \\
(0.013)\end{array}$ & $\begin{array}{l}-0.003 \\
(0.007)\end{array}$ \\
\hline Sales between $\$ 50,000$ - $\$ 999,999$ & $\begin{array}{c}0.104^{* * *} \\
(0.024)\end{array}$ & $\begin{array}{l}-0.013 \\
(0.023)\end{array}$ & $\begin{array}{c}0.018 \\
(0.015)\end{array}$ & $\begin{array}{l}-0.007 \\
(0.013)\end{array}$ & $\begin{array}{c}-0.025^{*} \\
(0.013)\end{array}$ & $\begin{array}{l}0.018^{* *} \\
(0.008)\end{array}$ \\
\hline Sales $\$ 1,000,000$ or more & $\begin{array}{c}0.007 \\
(0.024)\end{array}$ & $\begin{array}{l}-0.018 \\
(0.023)\end{array}$ & $\begin{array}{l}0.030^{*} \\
(0.015)\end{array}$ & $\begin{array}{c}0.018 \\
(0.013)\end{array}$ & $\begin{array}{l}-0.017 \\
(0.014)\end{array}$ & $\begin{array}{c}0.052^{* * *} \\
(0.009)\end{array}$ \\
\hline $\begin{array}{l}\text { In-person interactions - Half } \\
\text { or less }\end{array}$ & $\begin{array}{c}-0.026^{* * *} \\
(0.008)\end{array}$ & $\begin{array}{c}0.041^{* * *} \\
(0.007)\end{array}$ & $\begin{array}{l}-0.047^{* * *} \\
(0.006)\end{array}$ & $\begin{array}{c}0.018^{* * *} \\
(0.004)\end{array}$ & $\begin{array}{l}-0.004 \\
(0.004)\end{array}$ & $\begin{array}{l}-0.010^{* * *} \\
(0.003)\end{array}$ \\
\hline Male-owned or managed & $\begin{array}{l}-0.011 \\
(0.007)\end{array}$ & $\begin{array}{l}-0.001 \\
(0.007)\end{array}$ & $\begin{array}{c}0.040^{* * *} \\
(0.005)\end{array}$ & $\begin{array}{l}-0.003 \\
(0.004)\end{array}$ & $\begin{array}{l}-0.021^{* * *} \\
(0.003)\end{array}$ & $\begin{array}{l}-0.002 \\
(0.003)\end{array}$ \\
\hline $\begin{array}{l}\text { Obs. } \\
R^{2}\end{array}$ & $\begin{array}{c}16,573 \\
0.016\end{array}$ & $\begin{array}{c}16,573 \\
0.011\end{array}$ & $\begin{array}{c}16,573 \\
0.022\end{array}$ & $\begin{array}{c}16,573 \\
0.016\end{array}$ & $\begin{array}{c}16,573 \\
0.011\end{array}$ & $\begin{array}{c}16,573 \\
0.017\end{array}$ \\
\hline
\end{tabular}




\section{Table 6: Business Operations}

This table looks at how business operations vary by firm and owner characteristics. In Column 1, businesses were asked "Since the start of the coronavirus (COVID-19) pandemic, which of the following reflects the work load of this business?". The dependent variable takes a value of one if the response was "Lower than normal". In Column 2, businesses were asked "How long do you expect this business to stay open if the current circumstances persist?". The dependent variable takes a value of one if the response was "More than 6 months". The omitted base groups are age - less than 1 year, industry - agriculture or mining, sales - business not operational in 2019, in-person interactions more than half of the interactions are in-person, and gender - female-owned or managed. Other variables are as defined in Table 3.

\begin{tabular}{|c|c|c|}
\hline & $\begin{array}{c}\text { (1) } \\
\text { Lower work-load }\end{array}$ & $\begin{array}{c}(2) \\
\text { Survival }\end{array}$ \\
\hline Age - Between 1 and 2 years & $\begin{array}{c}0.039 \\
(0.046)\end{array}$ & $\begin{array}{c}0.023 \\
(0.046)\end{array}$ \\
\hline Age - Between 2 and 5 years & $\begin{array}{c}0.051 \\
(0.042)\end{array}$ & $\begin{array}{c}0.044 \\
(0.043)\end{array}$ \\
\hline Age - 5 years or more & $\begin{array}{c}0.026 \\
(0.040)\end{array}$ & $\begin{array}{c}0.062 \\
(0.040)\end{array}$ \\
\hline Construction & $\begin{array}{c}0.304^{* * *} \\
(0.060)\end{array}$ & $\begin{array}{l}-0.061 \\
(0.064)\end{array}$ \\
\hline Hotels, cafes, and restaurants & $\begin{array}{c}0.465^{* * *} \\
(0.056)\end{array}$ & $\begin{array}{l}-0.227^{* * *} \\
(0.064)\end{array}$ \\
\hline Information and communication & $\begin{array}{c}0.240^{* * *} \\
(0.054)\end{array}$ & $\begin{array}{c}0.032 \\
(0.060)\end{array}$ \\
\hline Manufacturing & $\begin{array}{c}0.396^{* * *} \\
(0.067)\end{array}$ & $\begin{array}{l}-0.218^{* * *} \\
(0.072)\end{array}$ \\
\hline Other & $\begin{array}{c}0.292^{* * *} \\
(0.048)\end{array}$ & $\begin{array}{l}-0.048 \\
(0.055)\end{array}$ \\
\hline Retail and wholesale trade & $\begin{array}{c}0.315^{* * *} \\
(0.049)\end{array}$ & $\begin{array}{c}-0.098^{*} \\
(0.056)\end{array}$ \\
\hline Services & $\begin{array}{c}0.355^{* * *} \\
(0.047)\end{array}$ & $\begin{array}{l}-0.059 \\
(0.054)\end{array}$ \\
\hline Transportation and logistics & $\begin{array}{c}0.429^{* * *} \\
(0.068)\end{array}$ & $\begin{array}{l}-0.079 \\
(0.071)\end{array}$ \\
\hline Sales less than $\$ 50,000$ & $\begin{array}{c}0.030 \\
(0.056)\end{array}$ & $\begin{array}{l}-0.057 \\
(0.056)\end{array}$ \\
\hline Sales between $\$ 50,000$ - $\$ 999,999$ & $\begin{array}{c}0.061 \\
(0.059)\end{array}$ & $\begin{array}{l}-0.066 \\
(0.059)\end{array}$ \\
\hline Sales $\$ 1,000,000$ or more & $\begin{array}{l}-0.040 \\
(0.061)\end{array}$ & $\begin{array}{l}0.142^{* *} \\
(0.061)\end{array}$ \\
\hline $\begin{array}{l}\text { In-person interactions - Half } \\
\text { or less }\end{array}$ & $\begin{array}{l}-0.118^{* * *} \\
(0.019)\end{array}$ & $\begin{array}{c}0.069^{* * *} \\
(0.019)\end{array}$ \\
\hline Male-owned or managed & $\begin{array}{c}0.030 \\
(0.018) \\
\end{array}$ & $\begin{array}{l}-0.013 \\
(0.018) \\
\end{array}$ \\
\hline $\begin{array}{l}\text { Obs. } \\
R^{2}\end{array}$ & $\begin{array}{l}3,025 \\
0.050\end{array}$ & $\begin{array}{l}3,025 \\
0.052\end{array}$ \\
\hline
\end{tabular}




\section{Table 7: Business Actions}

This table looks at how business actions in response to COVID-19 vary by firm and owner characteristics. Businesses were asked "What has this business done so far to help reduce the spread of the coronavirus (COVID-19)?". The dependent variable takes a value of one if the response is "Increased online interaction with clients or customers" (Column 1), "More frequent cleaning of office or workspaces" (Column 2), "Provided gloves, masks, hand sanitizer, or other protective equipment to employees/workers" (Column 3), "Provided hand sanitizer or cleaning wipes for client or customer use" (Column 4), "Requested employees/workers work from home" (Column 5), or "Closed physical location(s)" (Column 6). Respondents could select multiple options. The omitted base groups are age - less than 1 year, industry - agriculture or mining, sales - business not operational in 2019, in-person interactions - more than half of the interactions are in-person, and gender - female-owned or managed. Other variables are as defined in Table 3.

\begin{tabular}{|c|c|c|c|c|c|c|}
\hline & $\begin{array}{l}(1) \\
\text { Increased } \\
\text { online } \\
\text { presence }\end{array}$ & $\begin{array}{c}(2) \\
\text { More } \\
\text { frequent } \\
\text { cleaning }\end{array}$ & $\begin{array}{c}\text { (3) } \\
\text { PPE to } \\
\text { employees }\end{array}$ & $\begin{array}{l}\text { (4) } \\
\text { Cleaning } \\
\text { products } \\
\text { for clients }\end{array}$ & $\begin{array}{c}\text { (5) } \\
\text { WFH for } \\
\text { employees }\end{array}$ & $\begin{array}{c}\text { (6) } \\
\text { Closed } \\
\text { locations }\end{array}$ \\
\hline Age - Between 1 and 2 years & $\begin{array}{l}-0.028 \\
(0.046)\end{array}$ & $\begin{array}{c}0.009 \\
(0.042)\end{array}$ & $\begin{array}{c}-0.075^{*} \\
(0.041)\end{array}$ & $\begin{array}{l}-0.036 \\
(0.038)\end{array}$ & $\begin{array}{l}-0.027 \\
(0.036)\end{array}$ & $\begin{array}{c}0.026 \\
(0.040)\end{array}$ \\
\hline Age - Between 2 and 5 years & $\begin{array}{c}0.040 \\
(0.043)\end{array}$ & $\begin{array}{c}0.035 \\
(0.040)\end{array}$ & $\begin{array}{l}-0.021 \\
(0.040)\end{array}$ & $\begin{array}{c}0.023 \\
(0.037)\end{array}$ & $\begin{array}{c}0.013 \\
(0.035)\end{array}$ & $\begin{array}{c}0.057 \\
(0.037)\end{array}$ \\
\hline Age - 5 years or more & $\begin{array}{l}-0.012 \\
(0.041)\end{array}$ & $\begin{array}{c}0.050 \\
(0.037)\end{array}$ & $\begin{array}{l}-0.010 \\
(0.037)\end{array}$ & $\begin{array}{c}0.031 \\
(0.034)\end{array}$ & $\begin{array}{c}0.042 \\
(0.033)\end{array}$ & $\begin{array}{l}0.082^{* *} \\
(0.034)\end{array}$ \\
\hline Construction & $\begin{array}{l}-0.003 \\
(0.062)\end{array}$ & $\begin{array}{c}-0.119^{* *} \\
(0.060)\end{array}$ & $\begin{array}{c}0.098 \\
(0.064)\end{array}$ & $\begin{array}{l}-0.040 \\
(0.061)\end{array}$ & $\begin{array}{c}0.052 \\
(0.050)\end{array}$ & $\begin{array}{c}0.020 \\
(0.053)\end{array}$ \\
\hline Hotels, cafes, and restaurants & $\begin{array}{l}0.139^{* *} \\
(0.062)\end{array}$ & $\begin{array}{c}0.160^{* * *} \\
(0.059)\end{array}$ & $\begin{array}{c}0.214^{* * *} \\
(0.061)\end{array}$ & $\begin{array}{l}0.150^{* *} \\
(0.060)\end{array}$ & $\begin{array}{l}-0.049 \\
(0.047)\end{array}$ & $\begin{array}{l}0.098^{*} \\
(0.055)\end{array}$ \\
\hline Information and communication & $\begin{array}{c}0.253^{* * *} \\
(0.057)\end{array}$ & $\begin{array}{c}-0.141^{* *} \\
(0.057)\end{array}$ & $\begin{array}{c}-0.148^{* * *} \\
(0.057)\end{array}$ & $\begin{array}{c}-0.127^{* *} \\
(0.053)\end{array}$ & $\begin{array}{c}0.377^{* * *} \\
(0.049)\end{array}$ & $\begin{array}{c}0.175^{* * *} \\
(0.051)\end{array}$ \\
\hline Manufacturing & $\begin{array}{c}0.105 \\
(0.072)\end{array}$ & $\begin{array}{c}0.043 \\
(0.068)\end{array}$ & $\begin{array}{c}0.108 \\
(0.067)\end{array}$ & $\begin{array}{c}0.059 \\
(0.064)\end{array}$ & $\begin{array}{c}0.299^{* * * *} \\
(0.060)\end{array}$ & $\begin{array}{l}-0.014 \\
(0.059)\end{array}$ \\
\hline Other & $\begin{array}{c}0.182^{* * *} \\
(0.053)\end{array}$ & $\begin{array}{l}-0.032 \\
(0.052)\end{array}$ & $\begin{array}{l}-0.044 \\
(0.054)\end{array}$ & $\begin{array}{c}0.031 \\
(0.051)\end{array}$ & $\begin{array}{c}0.255^{* * *} \\
(0.043)\end{array}$ & $\begin{array}{c}0.212^{* * *} \\
(0.046)\end{array}$ \\
\hline Retail and wholesale trade & $\begin{array}{c}0.183^{* * *} \\
(0.054)\end{array}$ & $\begin{array}{c}0.044 \\
(0.052)\end{array}$ & $\begin{array}{l}-0.003 \\
(0.054)\end{array}$ & $\begin{array}{c}0.024 \\
(0.051)\end{array}$ & $\begin{array}{c}0.059 \\
(0.042)\end{array}$ & $\begin{array}{c}0.139^{* * *} \\
(0.046)\end{array}$ \\
\hline Services & $\begin{array}{c}0.195^{* * *} \\
(0.052)\end{array}$ & $\begin{array}{l}-0.058 \\
(0.051)\end{array}$ & $\begin{array}{l}-0.051 \\
(0.053)\end{array}$ & $\begin{array}{c}0.019 \\
(0.050)\end{array}$ & $\begin{array}{c}0.244^{* * *} \\
(0.042)\end{array}$ & $\begin{array}{c}0.207^{* * *} \\
(0.045)\end{array}$ \\
\hline Transportation and logistics & $\begin{array}{c}0.021 \\
(0.072)\end{array}$ & $\begin{array}{c}0.013 \\
(0.070)\end{array}$ & $\begin{array}{l}0.121^{*} \\
(0.071)\end{array}$ & $\begin{array}{c}0.040 \\
(0.069)\end{array}$ & $\begin{array}{l}0.150^{* *} \\
(0.061)\end{array}$ & $\begin{array}{l}-0.033 \\
(0.061)\end{array}$ \\
\hline Sales less than $\$ 50,000$ & $\begin{array}{c}0.047 \\
(0.055)\end{array}$ & $\begin{array}{l}-0.082 \\
(0.052)\end{array}$ & $\begin{array}{c}-0.089^{*} \\
(0.052)\end{array}$ & $\begin{array}{l}-0.026 \\
(0.046)\end{array}$ & $\begin{array}{l}-0.012 \\
(0.043)\end{array}$ & $\begin{array}{l}-0.009 \\
(0.045)\end{array}$ \\
\hline Sales between $\$ 50,000$ - $\$ 999,999$ & $\begin{array}{l}0.126^{* *} \\
(0.059)\end{array}$ & $\begin{array}{c}0.089 \\
(0.055)\end{array}$ & $\begin{array}{c}0.064 \\
(0.055)\end{array}$ & $\begin{array}{c}0.143^{* * *} \\
(0.050)\end{array}$ & $\begin{array}{c}0.176^{* * *} \\
(0.046)\end{array}$ & $\begin{array}{c}0.126^{* * *} \\
(0.049)\end{array}$ \\
\hline Sales $\$ 1,000,000$ or more & $\begin{array}{c}0.168^{* * *} \\
(0.060)\end{array}$ & $\begin{array}{c}0.246^{* * *} \\
(0.056)\end{array}$ & $\begin{array}{c}0.253^{* * *} \\
(0.057)\end{array}$ & $\begin{array}{c}0.274^{* * *} \\
(0.052)\end{array}$ & $\begin{array}{c}0.419^{* * *} \\
(0.048)\end{array}$ & $\begin{array}{c}0.194^{* * *} \\
(0.051)\end{array}$ \\
\hline $\begin{array}{l}\text { In-person interactions - Half } \\
\text { or less }\end{array}$ & $\begin{array}{c}0.110^{* * *} \\
(0.018)\end{array}$ & $\begin{array}{l}-0.150^{* * *} \\
(0.018)\end{array}$ & $\begin{array}{l}-0.170^{* * *} \\
(0.018)\end{array}$ & $\begin{array}{l}-0.177^{* * *} \\
(0.018)\end{array}$ & $\begin{array}{c}0.105^{* * *} \\
(0.017)\end{array}$ & $\begin{array}{c}0.004 \\
(0.018)\end{array}$ \\
\hline Male-owned or managed & $\begin{array}{l}-0.085^{* * *} \\
(0.018)\end{array}$ & $\begin{array}{l}-0.048^{* * *} \\
(0.017)\end{array}$ & $\begin{array}{l}-0.001 \\
(0.017)\end{array}$ & $\begin{array}{l}-0.002 \\
(0.017)\end{array}$ & $\begin{array}{l}-0.006 \\
(0.017)\end{array}$ & $\begin{array}{l}-0.055^{* * *} \\
(0.017)\end{array}$ \\
\hline $\begin{array}{l}\text { Obs. } \\
R^{2}\end{array}$ & $\begin{array}{l}3,029 \\
0.047\end{array}$ & $\begin{array}{l}3,029 \\
0.134\end{array}$ & $\begin{array}{l}3,029 \\
0.168\end{array}$ & $\begin{array}{l}3,029 \\
0.139\end{array}$ & $\begin{array}{l}3,029 \\
0.199\end{array}$ & $\begin{array}{l}3,029 \\
0.062\end{array}$ \\
\hline
\end{tabular}




\section{Table 8: Business Changes}

This table looks at how changes implemented by the business vary by firm and owner characteristics. Businesses that responded yes to "Did this business have to change anything compared to standard business work/operations due to the coronavirus (COVID-19) pandemic?" were asked "What did this business have to change?". The dependent variable takes a value of one if the response is "Client communication or interaction" (Column 1), "Operating hours" (Column 2), "Use of online tools" (Column 3), or "Employee/worker location" (Column 4). Respondents could select multiple options. The omitted base groups are age - less than 1 year, industry - agriculture or mining, sales - business not operational in 2019, in-person interactions - more than half of the interactions are in-person, and gender - female-owned or managed. Other variables are as defined in Table 3.

\begin{tabular}{|c|c|c|c|c|}
\hline & $\begin{array}{c}(1) \\
\text { Client } \\
\text { communication } \\
\text { or interaction }\end{array}$ & $\begin{array}{c}\text { (2) } \\
\text { Operating } \\
\text { hours }\end{array}$ & $\begin{array}{c}\text { (3) } \\
\text { Use of } \\
\text { online tools }\end{array}$ & $\begin{array}{c}(4) \\
\text { Employee } \\
\text { location }\end{array}$ \\
\hline Age - Between 1 and 2 years & $\begin{array}{c}0.012 \\
(0.056)\end{array}$ & $\begin{array}{l}-0.015 \\
(0.056)\end{array}$ & $\begin{array}{c}0.026 \\
(0.058)\end{array}$ & $\begin{array}{c}0.028 \\
(0.046)\end{array}$ \\
\hline Age - Between 2 and 5 years & $\begin{array}{c}-0.008 \\
(0.052)\end{array}$ & $\begin{array}{c}-0.014 \\
(0.052)\end{array}$ & $\begin{array}{l}0.096^{*} \\
(0.054)\end{array}$ & $\begin{array}{c}0.054 \\
(0.044)\end{array}$ \\
\hline Age - 5 years or more & $\begin{array}{r}-0.028 \\
(0.050)\end{array}$ & $\begin{array}{l}-0.011 \\
(0.049)\end{array}$ & $\begin{array}{c}0.051 \\
(0.051)\end{array}$ & $\begin{array}{l}0.095^{* *} \\
(0.041)\end{array}$ \\
\hline Construction & $\begin{array}{c}-0.017 \\
(0.076)\end{array}$ & $\begin{array}{r}-0.052 \\
(0.077)\end{array}$ & $\begin{array}{c}0.004 \\
(0.075)\end{array}$ & $\begin{array}{l}0.168^{* *} \\
(0.069)\end{array}$ \\
\hline Hotels, cafes, and restaurants & $\begin{array}{c}-0.054 \\
(0.074)\end{array}$ & $\begin{array}{c}0.227^{* * *} \\
(0.074)\end{array}$ & $\begin{array}{c}0.076 \\
(0.074)\end{array}$ & $\begin{array}{l}-0.014 \\
(0.064)\end{array}$ \\
\hline Information and communication & $\begin{array}{c}0.045 \\
(0.072)\end{array}$ & $\begin{array}{c}0.004 \\
(0.073)\end{array}$ & $\begin{array}{l}0.162^{* *} \\
(0.072)\end{array}$ & $\begin{array}{c}0.366^{* * *} \\
(0.064)\end{array}$ \\
\hline Manufacturing & $\begin{array}{c}-0.187^{* *} \\
(0.087)\end{array}$ & $\begin{array}{l}0.151^{*} \\
(0.086)\end{array}$ & $\begin{array}{c}0.070 \\
(0.088)\end{array}$ & $\begin{array}{c}0.238^{* * *} \\
(0.079)\end{array}$ \\
\hline Other & $\begin{array}{c}0.051 \\
(0.066)\end{array}$ & $\begin{array}{c}0.021 \\
(0.067)\end{array}$ & $\begin{array}{c}0.207^{* * *} \\
(0.066)\end{array}$ & $\begin{array}{c}0.230^{* * *} \\
(0.058)\end{array}$ \\
\hline Retail and wholesale trade & $\begin{array}{l}-0.048 \\
(0.067)\end{array}$ & $\begin{array}{l}0.173^{* *} \\
(0.068)\end{array}$ & $\begin{array}{l}0.164^{* *} \\
(0.067)\end{array}$ & $\begin{array}{c}0.091 \\
(0.059)\end{array}$ \\
\hline Services & $\begin{array}{c}0.086 \\
(0.065)\end{array}$ & $\begin{array}{c}0.027 \\
(0.066)\end{array}$ & $\begin{array}{c}0.170^{* * *} \\
(0.065)\end{array}$ & $\begin{array}{c}0.218^{* * *} \\
(0.057)\end{array}$ \\
\hline Transportation and logistics & $\begin{array}{l}-0.091 \\
(0.087)\end{array}$ & $\begin{array}{c}0.062 \\
(0.088)\end{array}$ & $\begin{array}{l}-0.039 \\
(0.083)\end{array}$ & $\begin{array}{c}0.035 \\
(0.075)\end{array}$ \\
\hline Sales less than $\$ 50,000$ & $\begin{array}{c}-0.000 \\
(0.068)\end{array}$ & $\begin{array}{c}0.097 \\
(0.066)\end{array}$ & $\begin{array}{c}-0.073 \\
(0.070)\end{array}$ & $\begin{array}{c}-0.006 \\
(0.053)\end{array}$ \\
\hline Sales between $\$ 50,000$ - $\$ 999,999$ & $\begin{array}{c}0.107 \\
(0.071)\end{array}$ & $\begin{array}{c}0.186^{* * *} \\
(0.070)\end{array}$ & $\begin{array}{c}-0.029 \\
(0.073)\end{array}$ & $\begin{array}{c}0.148^{* * *} \\
(0.057)\end{array}$ \\
\hline Sales $\$ 1,000,000$ or more & $\begin{array}{l}0.147^{* *} \\
(0.073)\end{array}$ & $\begin{array}{c}0.199^{* * *} \\
(0.071)\end{array}$ & $\begin{array}{c}0.074 \\
(0.075)\end{array}$ & $\begin{array}{c}0.364^{* * *} \\
(0.059)\end{array}$ \\
\hline $\begin{array}{l}\text { In-person interactions - Half } \\
\text { or less }\end{array}$ & $\begin{array}{l}-0.014 \\
(0.020)\end{array}$ & $\begin{array}{c}-0.118^{* * * *} \\
(0.021)\end{array}$ & $\begin{array}{l}0.067^{* * *} \\
(0.021)\end{array}$ & $\begin{array}{l}0.084^{* * *} \\
(0.020)\end{array}$ \\
\hline Male-owned or managed & $\begin{array}{c}-0.077^{* * *} \\
(0.020)\end{array}$ & $\begin{array}{l}-0.005 \\
(0.021)\end{array}$ & $\begin{array}{c}-0.055^{* * *} \\
(0.021)\end{array}$ & $\begin{array}{c}-0.045^{* *} \\
(0.019)\end{array}$ \\
\hline $\begin{array}{l}\text { Obs. } \\
R^{2}\end{array}$ & $\begin{array}{l}2,316 \\
0.036\end{array}$ & $\begin{array}{l}2,316 \\
0.057\end{array}$ & $\begin{array}{l}2,316 \\
0.036\end{array}$ & $\begin{array}{l}2,316 \\
0.150\end{array}$ \\
\hline
\end{tabular}




\section{Table 9: Business Struggles}

This table looks at how business struggles vary by firm and owner characteristics. Businesses were asked "Is this business struggling to pay any of the following?". The dependent variable takes a value of one if the response is "Bills or accounts payable" (Column 1), "Debt or loans" (Column 2), "Employee/worker salaries and wages" (Column 3), "Rent or lease" (Column 4), or "Taxes" (Column 5). Respondents could select multiple options. The omitted base groups are age - less than 1 year, industry - agriculture or mining, sales - business not operational in 2019, in-person interactions more than half of the interactions are in-person, and gender - female-owned or managed. Other variables are as defined in Table 3.

\begin{tabular}{|c|c|c|c|c|c|}
\hline & $\begin{array}{c}\quad(1) \\
\text { Bills or } \\
\text { accounts } \\
\text { payable }\end{array}$ & $\begin{array}{c}(2) \\
\begin{array}{l}\text { Debt or } \\
\text { loans }\end{array}\end{array}$ & $\begin{array}{c}(3) \\
\text { Employee } \\
\text { wages }\end{array}$ & $\begin{array}{c}(4) \\
\begin{array}{c}\text { Rent or } \\
\text { lease }\end{array}\end{array}$ & $\begin{array}{c}(5) \\
\text { Taxes }\end{array}$ \\
\hline Age - Between 1 and 2 years & $\begin{array}{c}0.016 \\
(0.040)\end{array}$ & $\begin{array}{c}0.035 \\
(0.036)\end{array}$ & $\begin{array}{c}-0.044 \\
(0.035)\end{array}$ & $\begin{array}{l}-0.018 \\
(0.037)\end{array}$ & $\begin{array}{c}0.007 \\
(0.032)\end{array}$ \\
\hline Age - Between 2 and 5 years & $\begin{array}{l}-0.003 \\
(0.037)\end{array}$ & $\begin{array}{c}0.053 \\
(0.034)\end{array}$ & $\begin{array}{c}0.020 \\
(0.033)\end{array}$ & $\begin{array}{l}-0.004 \\
(0.035)\end{array}$ & $\begin{array}{l}0.059 * \\
(0.031)\end{array}$ \\
\hline Age - 5 years or more & $\begin{array}{l}-0.008 \\
(0.035)\end{array}$ & $\begin{array}{c}0.015 \\
(0.031)\end{array}$ & $\begin{array}{l}-0.019 \\
(0.031)\end{array}$ & $\begin{array}{l}-0.023 \\
(0.033)\end{array}$ & $\begin{array}{c}0.017 \\
(0.029)\end{array}$ \\
\hline Construction & $\begin{array}{l}-0.054 \\
(0.064)\end{array}$ & $\begin{array}{l}-0.017 \\
(0.059)\end{array}$ & $\begin{array}{l}-0.028 \\
(0.058)\end{array}$ & $\begin{array}{l}-0.007 \\
(0.050)\end{array}$ & $\begin{array}{c}0.046 \\
(0.050)\end{array}$ \\
\hline Hotels, cafes, and restaurants & $\begin{array}{c}0.089 \\
(0.064)\end{array}$ & $\begin{array}{l}0.104^{*} \\
(0.061)\end{array}$ & $\begin{array}{c}0.163^{* * *} \\
(0.060)\end{array}$ & $\begin{array}{c}0.303^{* * *} \\
(0.055)\end{array}$ & $\begin{array}{c}0.286^{* * *} \\
(0.054)\end{array}$ \\
\hline Information and communication & $\begin{array}{l}-0.033 \\
(0.061)\end{array}$ & $\begin{array}{l}-0.072 \\
(0.055)\end{array}$ & $\begin{array}{c}0.086 \\
(0.056)\end{array}$ & $\begin{array}{c}0.045 \\
(0.048)\end{array}$ & $\begin{array}{c}0.001 \\
(0.046)\end{array}$ \\
\hline Manufacturing & $\begin{array}{l}-0.024 \\
(0.071)\end{array}$ & $\begin{array}{l}-0.059 \\
(0.062)\end{array}$ & $\begin{array}{c}0.071 \\
(0.069)\end{array}$ & $\begin{array}{l}0.098^{*} \\
(0.058)\end{array}$ & $\begin{array}{c}-0.061 \\
(0.048)\end{array}$ \\
\hline Other & $\begin{array}{l}-0.093 \\
(0.057)\end{array}$ & $\begin{array}{l}-0.056 \\
(0.052)\end{array}$ & $\begin{array}{c}0.034 \\
(0.052)\end{array}$ & $\begin{array}{c}0.072 \\
(0.045)\end{array}$ & $\begin{array}{c}0.000 \\
(0.043)\end{array}$ \\
\hline Retail and wholesale trade & $\begin{array}{l}-0.026 \\
(0.057)\end{array}$ & $\begin{array}{l}-0.029 \\
(0.052)\end{array}$ & $\begin{array}{l}-0.019 \\
(0.051)\end{array}$ & $\begin{array}{c}0.137^{* * *} \\
(0.045)\end{array}$ & $\begin{array}{c}0.061 \\
(0.043)\end{array}$ \\
\hline Services & $\begin{array}{l}-0.021 \\
(0.056)\end{array}$ & $\begin{array}{c}-0.007 \\
(0.051)\end{array}$ & $\begin{array}{c}0.068 \\
(0.051)\end{array}$ & $\begin{array}{c}0.120^{* * *} \\
(0.044)\end{array}$ & $\begin{array}{c}0.047 \\
(0.042)\end{array}$ \\
\hline Transportation and logistics & $\begin{array}{c}0.035 \\
(0.072)\end{array}$ & $\begin{array}{c}0.021 \\
(0.066)\end{array}$ & $\begin{array}{c}0.020 \\
(0.068)\end{array}$ & $\begin{array}{l}0.110^{*} \\
(0.060)\end{array}$ & $\begin{array}{c}0.069 \\
(0.058)\end{array}$ \\
\hline Sales less than $\$ 50,000$ & $\begin{array}{l}0.081^{*} \\
(0.049)\end{array}$ & $\begin{array}{c}0.004 \\
(0.044)\end{array}$ & $\begin{array}{l}-0.040 \\
(0.045)\end{array}$ & $\begin{array}{l}-0.013 \\
(0.048)\end{array}$ & $\begin{array}{c}0.030 \\
(0.038)\end{array}$ \\
\hline Sales between $\$ 50,000$ - $\$ 999,999$ & $\begin{array}{c}0.162^{* * *} \\
(0.052)\end{array}$ & $\begin{array}{c}0.073 \\
(0.047)\end{array}$ & $\begin{array}{c}0.153^{* * *} \\
(0.048)\end{array}$ & $\begin{array}{c}0.077 \\
(0.051)\end{array}$ & $\begin{array}{c}0.131^{* * *} \\
(0.040)\end{array}$ \\
\hline Sales $\$ 1,000,000$ or more & $\begin{array}{c}-0.014 \\
(0.054)\end{array}$ & $\begin{array}{c}-0.081^{*} \\
(0.048)\end{array}$ & $\begin{array}{l}0.101^{\text {** }} \\
(0.051)\end{array}$ & $\begin{array}{c}-0.093^{*} \\
(0.052)\end{array}$ & $\begin{array}{l}-0.009 \\
(0.042)\end{array}$ \\
\hline $\begin{array}{l}\text { In-person interactions - Half } \\
\text { or less }\end{array}$ & $\begin{array}{c}-0.103^{* * *} \\
(0.017)\end{array}$ & $\begin{array}{c}-0.050^{* * *} \\
(0.016)\end{array}$ & $\begin{array}{l}-0.081^{* * *} \\
(0.017)\end{array}$ & $\begin{array}{l}-0.105^{* * *} \\
(0.016)\end{array}$ & $\begin{array}{l}-0.046^{* * * *} \\
(0.015)\end{array}$ \\
\hline Male-owned or managed & $\begin{array}{l}-0.005 \\
(0.017) \\
\end{array}$ & $\begin{array}{c}0.018 \\
(0.015) \\
\end{array}$ & $\begin{array}{l}-0.015 \\
(0.016) \\
\end{array}$ & $\begin{array}{l}0.029^{*} \\
(0.015) \\
\end{array}$ & $\begin{array}{c}0.023 \\
(0.014) \\
\end{array}$ \\
\hline $\begin{array}{l}\text { Obs. } \\
R^{2}\end{array}$ & $\begin{array}{l}3,473 \\
0.043\end{array}$ & $\begin{array}{l}3,473 \\
0.035\end{array}$ & $\begin{array}{l}3,473 \\
0.061\end{array}$ & $\begin{array}{l}3,473 \\
0.063\end{array}$ & $\begin{array}{l}3,473 \\
0.062\end{array}$ \\
\hline
\end{tabular}




\section{Table 10: Sources of Formal Financing}

This table looks at how sources of formal financing vary by firm and owner characteristics. In Column 1, the dependent variable takes a value of one if businesses responded yes to "At this time, does this business have a line of credit or a loan from a financial institution or bank?". In Columns 2 to 6 , businesses were asked "In the past 30 days, which of the following sources of capital did this business apply for?". The dependent variable takes a value of one if the response is "Bank loans" (Column 2), "Government loans" (Column 3), "Grants from the government" (Column 4), "Grants from private-sector companies or agencies" (Column 5), or "Crowdsourced capital" (Column 6). Respondents could select multiple options. The omitted base groups are age - less than 1 year, industry - agriculture or mining, sales - business not operational in 2019, in-person interactions more than half of the interactions are in-person, and gender - female-owned or managed. Other variables are as defined in Table 3.

\begin{tabular}{|c|c|c|c|c|c|c|}
\hline & $\begin{array}{c}(1) \\
\text { Bank Loan } \\
\text { Outstanding } \\
\end{array}$ & $\begin{array}{c}(2) \\
\text { Bank Loan } \\
\text { Application }\end{array}$ & $\begin{array}{c}(3) \\
\text { Loans from } \\
\text { Government } \\
\end{array}$ & $\begin{array}{c}(4) \\
\text { Grants from } \\
\text { Government } \\
\end{array}$ & $\begin{array}{c}5) \\
\text { Private } \\
\text { Grants } \\
\end{array}$ & $\begin{array}{c}(6) \\
\text { Crowdsourced } \\
\text { Capital } \\
\end{array}$ \\
\hline Age - Between 1 and 2 years & $\begin{array}{l}-0.008 \\
(0.030)\end{array}$ & $\begin{array}{l}-0.021 \\
(0.025)\end{array}$ & $\begin{array}{c}0.038 \\
(0.032)\end{array}$ & $\begin{array}{l}-0.006 \\
(0.033)\end{array}$ & $\begin{array}{c}0.026 \\
(0.021)\end{array}$ & $\begin{array}{c}0.000 \\
(0.011)\end{array}$ \\
\hline Age - Between 2 and 5 years & $\begin{array}{l}-0.021 \\
(0.028)\end{array}$ & $\begin{array}{l}-0.014 \\
(0.025)\end{array}$ & $\begin{array}{c}0.045 \\
(0.030)\end{array}$ & $\begin{array}{c}0.046 \\
(0.031)\end{array}$ & $\begin{array}{c}0.055^{* * *} \\
(0.020)\end{array}$ & $\begin{array}{c}0.010 \\
(0.012)\end{array}$ \\
\hline Age -5 years or more & $\begin{array}{c}0.024 \\
(0.027)\end{array}$ & $\begin{array}{l}-0.036 \\
(0.023)\end{array}$ & $\begin{array}{c}0.017 \\
(0.028)\end{array}$ & $\begin{array}{l}-0.015 \\
(0.029)\end{array}$ & $\begin{array}{c}0.015 \\
(0.018)\end{array}$ & $\begin{array}{l}-0.007 \\
(0.010)\end{array}$ \\
\hline Construction & $\begin{array}{l}-0.041 \\
(0.057)\end{array}$ & $\begin{array}{c}0.002 \\
(0.046)\end{array}$ & $\begin{array}{c}0.064 \\
(0.053)\end{array}$ & $\begin{array}{l}0.116^{* *} \\
(0.052)\end{array}$ & $\begin{array}{l}-0.030 \\
(0.030)\end{array}$ & $\begin{array}{c}-0.037^{*} \\
(0.021)\end{array}$ \\
\hline Hotels, cafes, and restaurants & $\begin{array}{l}-0.074 \\
(0.057)\end{array}$ & $\begin{array}{c}0.013 \\
(0.046)\end{array}$ & $\begin{array}{c}0.218^{* * *} \\
(0.053)\end{array}$ & $\begin{array}{c}0.206^{* * *} \\
(0.052)\end{array}$ & $\begin{array}{l}0.078^{* *} \\
(0.036)\end{array}$ & $\begin{array}{l}-0.016 \\
(0.023)\end{array}$ \\
\hline Information and communication & $\begin{array}{l}-0.066 \\
(0.053)\end{array}$ & $\begin{array}{l}-0.012 \\
(0.042)\end{array}$ & $\begin{array}{l}0.096^{* *} \\
(0.048)\end{array}$ & $\begin{array}{c}0.070 \\
(0.047)\end{array}$ & $\begin{array}{c}0.027 \\
(0.031)\end{array}$ & $\begin{array}{c}0.009 \\
(0.024)\end{array}$ \\
\hline Manufacturing & $\begin{array}{c}0.023 \\
(0.065)\end{array}$ & $\begin{array}{l}-0.008 \\
(0.053)\end{array}$ & $\begin{array}{c}0.076 \\
(0.063)\end{array}$ & $\begin{array}{c}0.062 \\
(0.059)\end{array}$ & $\begin{array}{l}-0.013 \\
(0.034)\end{array}$ & $\begin{array}{l}-0.003 \\
(0.027)\end{array}$ \\
\hline Other & $\begin{array}{c}-0.117^{* *} \\
(0.049)\end{array}$ & $\begin{array}{l}-0.022 \\
(0.039)\end{array}$ & $\begin{array}{l}0.090^{* *} \\
(0.044)\end{array}$ & $\begin{array}{l}0.102^{* *} \\
(0.043)\end{array}$ & $\begin{array}{l}0.057^{* *} \\
(0.029)\end{array}$ & $\begin{array}{l}-0.004 \\
(0.022)\end{array}$ \\
\hline Retail and wholesale trade & $\begin{array}{c}-0.094^{*} \\
(0.049)\end{array}$ & $\begin{array}{l}-0.029 \\
(0.039)\end{array}$ & $\begin{array}{l}0.087^{* *} \\
(0.044)\end{array}$ & $\begin{array}{l}0.080^{*} \\
(0.042)\end{array}$ & $\begin{array}{c}0.001 \\
(0.028)\end{array}$ & $\begin{array}{l}-0.021 \\
(0.021)\end{array}$ \\
\hline Services & $\begin{array}{c}-0.094^{* *} \\
(0.048)\end{array}$ & $\begin{array}{l}-0.031 \\
(0.038)\end{array}$ & $\begin{array}{c}0.112^{* * *} \\
(0.043)\end{array}$ & $\begin{array}{c}0.133^{* * * *} \\
(0.042)\end{array}$ & $\begin{array}{c}0.015 \\
(0.027)\end{array}$ & $\begin{array}{l}-0.014 \\
(0.021)\end{array}$ \\
\hline Transportation and logistics & $\begin{array}{l}-0.051 \\
(0.067)\end{array}$ & $\begin{array}{l}-0.015 \\
(0.052)\end{array}$ & $\begin{array}{l}0.117^{*} \\
(0.062)\end{array}$ & $\begin{array}{c}0.044 \\
(0.058)\end{array}$ & $\begin{array}{l}-0.001 \\
(0.036)\end{array}$ & $\begin{array}{l}-0.027 \\
(0.023)\end{array}$ \\
\hline Sales less than $\$ 50,000$ & $\begin{array}{c}0.009 \\
(0.035)\end{array}$ & $\begin{array}{c}0.022 \\
(0.030)\end{array}$ & $\begin{array}{l}-0.021 \\
(0.038)\end{array}$ & $\begin{array}{c}0.007 \\
(0.038)\end{array}$ & $\begin{array}{c}0.014 \\
(0.022)\end{array}$ & $\begin{array}{l}-0.012 \\
(0.017)\end{array}$ \\
\hline Sales between $\$ 50,000$ - $\$ 999,999$ & $\begin{array}{c}0.184^{* * * *} \\
(0.038)\end{array}$ & $\begin{array}{c}0.120^{* * *} \\
(0.032)\end{array}$ & $\begin{array}{c}0.233^{* * * *} \\
(0.041)\end{array}$ & $\begin{array}{c}0.209^{* * * *} \\
(0.042)\end{array}$ & $\begin{array}{c}0.040 \\
(0.025)\end{array}$ & $\begin{array}{l}-0.006 \\
(0.018)\end{array}$ \\
\hline Sales $\$ 1,000,000$ or more & $\begin{array}{c}0.358^{* * *} \\
(0.042)\end{array}$ & $\begin{array}{c}0.156^{* * *} \\
(0.035)\end{array}$ & $\begin{array}{c}0.231^{* * *} \\
(0.044)\end{array}$ & $\begin{array}{c}0.176^{* * *} \\
(0.044)\end{array}$ & $\begin{array}{c}0.040 \\
(0.027)\end{array}$ & $\begin{array}{l}-0.004 \\
(0.019)\end{array}$ \\
\hline $\begin{array}{l}\text { In-person interactions - Half } \\
\text { or less }\end{array}$ & $\begin{array}{l}-0.057^{* * *} \\
(0.016)\end{array}$ & $\begin{array}{l}-0.032^{* * *} \\
(0.012)\end{array}$ & $\begin{array}{l}-0.049 * * * \\
(0.016)\end{array}$ & $\begin{array}{l}-0.079 * * * \\
(0.016)\end{array}$ & $\begin{array}{l}-0.009 \\
(0.010)\end{array}$ & $\begin{array}{l}-0.009 \\
(0.006)\end{array}$ \\
\hline Male-owned or managed & $\begin{array}{c}0.022 \\
(0.015) \\
\end{array}$ & $\begin{array}{c}0.016 \\
(0.012) \\
\end{array}$ & $\begin{array}{l}-0.004 \\
(0.016) \\
\end{array}$ & $\begin{array}{l}-0.019 \\
(0.015) \\
\end{array}$ & $\begin{array}{l}-0.021^{* *} \\
(0.010) \\
\end{array}$ & $\begin{array}{c}0.002 \\
(0.006) \\
\end{array}$ \\
\hline $\begin{array}{l}\text { Obs. } \\
R^{2}\end{array}$ & $\begin{array}{l}3,476 \\
0.121\end{array}$ & $\begin{array}{l}3,476 \\
0.033\end{array}$ & $\begin{array}{l}3,476 \\
0.091\end{array}$ & $\begin{array}{l}3,476 \\
0.069\end{array}$ & $\begin{array}{l}3,476 \\
0.019\end{array}$ & $\begin{array}{l}3,476 \\
0.007\end{array}$ \\
\hline
\end{tabular}


Table 11: Internal vs. External Financing Share by Industry

This table presents information on the share of firms with access to sources of external and internal financing by industry. Firms are coded as having access to forms of internal financing if they have access to "Personal Savings", "Funds from family or friends", or "Loan from retirement funds". Firms are coded as having access to external financing if they have a loan or line of credit from a financial institution.

\begin{tabular}{|c|c|c|}
\hline Industry & $\begin{array}{c}(1) \\
\text { Internal Financing }\end{array}$ & $\begin{array}{c}(2) \\
\text { External Financing }\end{array}$ \\
\hline Agriculture or mining & .635 & .302 \\
\hline Construction & .465 & .363 \\
\hline Hotels, cafes, and restaurants & .479 & .320 \\
\hline Information and communication & .587 & .261 \\
\hline Manufacturing & .313 & .419 \\
\hline Retail and wholesale trade & .543 & .214 \\
\hline Services & .556 & .249 \\
\hline Transportation and logistics & .402 & .376 \\
\hline
\end{tabular}

Table 12: Remote-Work by Industry

This table presents information on the self-reported share of employees that could be working from home by industry. We compare it to the estimated share by Dingel and Neiman (2020). We have assumed a share of $100 \%, 75 \%, 50 \%, 25 \%$ and $0 \%$ if the respondent stated that "all", "more than half", "about half", "less than half" and "none" could work remotely, respectively.

\begin{tabular}{lcc}
\hline \hline \multicolumn{1}{c}{ Industry } & $(1)$ & $(2)$ \\
& Remote-Work Reported & Dingel \& Neiman (2020) \\
\hline Information and communication & .812 & .717 \\
Real estate activities & .764 & .418 \\
Professional services & .650 & .762 \\
Education and childcare services & .569 & .826 \\
Performing arts and entertainment & .563 & .297 \\
Manufacturing & .328 & .225 \\
Retail and wholesale trade & .326 & .330 \\
Agriculture, farming, forestry, or mining & .264 & .165 \\
Transportation and logistics & .239 & .186 \\
Construction & .215 & .186 \\
Hotels, cafes and restaurants & .089 & .035 \\
\hline \hline
\end{tabular}




\section{Table 13: Sources of Informal Financing}

This table looks at how sources of informal financing vary by firm and owner characteristics. Businesses were asked "Which of the following sources of private capital or funds does this business currently have access to?". The dependent variable takes a value of one if the respondent picks any of the options (Column 1), "Personal Savings" (Column 2), "Funds from family or friends" (Column 3), "Unemployment Benefits" (Column 4), "Loan from retirement funds" (Column 5), or "Community Donations" (Column 6). Respondents could select multiple options. The omitted base groups are age - less than 1 year, industry - agriculture or mining, sales - business not operational in 2019, in-person interactions - more than half of the interactions are in-person, and gender female-owned or managed. Other variables are as defined in Table 3.

\begin{tabular}{|c|c|c|c|c|c|c|}
\hline & $\begin{array}{c}(1) \\
\text { Informal } \\
\text { Financing } \\
\end{array}$ & $\begin{array}{c}\text { (2) } \\
\text { Personal } \\
\text { Savings } \\
\end{array}$ & $\begin{array}{l}\text { (3) } \\
\text { Family and } \\
\text { Friends }\end{array}$ & $\begin{array}{c}(4) \\
\text { Unemployment } \\
\text { Benefits }\end{array}$ & $\begin{array}{l}\text { (5) } \\
\text { Retirement } \\
\text { Funds }\end{array}$ & $\begin{array}{c}(6) \\
\text { Community } \\
\text { Donations }\end{array}$ \\
\hline Age - Between 1 and 2 years & $\begin{array}{l}-0.010 \\
(0.041)\end{array}$ & $\begin{array}{l}-0.030 \\
(0.042)\end{array}$ & $\begin{array}{l}-0.021 \\
(0.032)\end{array}$ & $\begin{array}{c}0.000 \\
(0.021)\end{array}$ & $\begin{array}{l}-0.005 \\
(0.019)\end{array}$ & $\begin{array}{c}0.005 \\
(0.018)\end{array}$ \\
\hline Age - Between 2 and 5 years & $\begin{array}{c}0.001 \\
(0.038)\end{array}$ & $\begin{array}{c}0.008 \\
(0.039)\end{array}$ & $\begin{array}{l}-0.010 \\
(0.030)\end{array}$ & $\begin{array}{l}-0.000 \\
(0.020)\end{array}$ & $\begin{array}{c}0.002 \\
(0.018)\end{array}$ & $\begin{array}{c}0.011 \\
(0.017)\end{array}$ \\
\hline Age - 5 years or more & $\begin{array}{c}0.020 \\
(0.036)\end{array}$ & $\begin{array}{l}-0.013 \\
(0.037)\end{array}$ & $\begin{array}{l}-0.003 \\
(0.029)\end{array}$ & $\begin{array}{c}0.002 \\
(0.020)\end{array}$ & $\begin{array}{c}0.016 \\
(0.017)\end{array}$ & $\begin{array}{c}0.013 \\
(0.015)\end{array}$ \\
\hline Construction & $\begin{array}{c}-0.136^{* *} \\
(0.061)\end{array}$ & $\begin{array}{l}-0.098 \\
(0.064)\end{array}$ & $\begin{array}{l}-0.022 \\
(0.046)\end{array}$ & $\begin{array}{l}-0.005 \\
(0.035)\end{array}$ & $\begin{array}{l}-0.059 \\
(0.039)\end{array}$ & $\begin{array}{c}-0.085^{* * *} \\
(0.030)\end{array}$ \\
\hline Hotels, cafes, and restaurants & $\begin{array}{l}-0.080 \\
(0.061)\end{array}$ & $\begin{array}{l}-0.101 \\
(0.064)\end{array}$ & $\begin{array}{c}0.006 \\
(0.048)\end{array}$ & $\begin{array}{l}-0.013 \\
(0.035)\end{array}$ & $\begin{array}{l}-0.038 \\
(0.039)\end{array}$ & $\begin{array}{l}-0.042 \\
(0.035)\end{array}$ \\
\hline Information and communication & $\begin{array}{l}-0.010 \\
(0.057)\end{array}$ & $\begin{array}{l}-0.004 \\
(0.060)\end{array}$ & $\begin{array}{c}0.030 \\
(0.046)\end{array}$ & $\begin{array}{c}0.004 \\
(0.031)\end{array}$ & $\begin{array}{l}-0.042 \\
(0.038)\end{array}$ & $\begin{array}{c}0.027 \\
(0.035)\end{array}$ \\
\hline Manufacturing & $\begin{array}{c}-0.197^{* * *} \\
(0.071)\end{array}$ & $\begin{array}{c}-0.228^{* * *} \\
(0.071)\end{array}$ & $\begin{array}{l}-0.034 \\
(0.050)\end{array}$ & $\begin{array}{l}-0.035 \\
(0.040)\end{array}$ & $\begin{array}{c}-0.108^{* * *} \\
(0.038)\end{array}$ & $\begin{array}{l}-0.060^{*} \\
(0.034)\end{array}$ \\
\hline Other & $\begin{array}{l}-0.056 \\
(0.053)\end{array}$ & $\begin{array}{l}-0.090 \\
(0.056)\end{array}$ & $\begin{array}{l}-0.027 \\
(0.042)\end{array}$ & $\begin{array}{c}0.004 \\
(0.029)\end{array}$ & $\begin{array}{l}-0.043 \\
(0.035)\end{array}$ & $\begin{array}{c}0.036 \\
(0.033)\end{array}$ \\
\hline Retail and wholesale trade & $\begin{array}{l}-0.077 \\
(0.053)\end{array}$ & $\begin{array}{l}-0.056 \\
(0.056)\end{array}$ & $\begin{array}{l}-0.013 \\
(0.043)\end{array}$ & $\begin{array}{l}-0.013 \\
(0.029)\end{array}$ & $\begin{array}{l}-0.048 \\
(0.035)\end{array}$ & $\begin{array}{l}-0.038 \\
(0.031)\end{array}$ \\
\hline Services & $\begin{array}{l}-0.052 \\
(0.052)\end{array}$ & $\begin{array}{l}-0.043 \\
(0.055)\end{array}$ & $\begin{array}{l}-0.015 \\
(0.042)\end{array}$ & $\begin{array}{c}0.002 \\
(0.028)\end{array}$ & $\begin{array}{l}-0.027 \\
(0.035)\end{array}$ & $\begin{array}{l}-0.021 \\
(0.031)\end{array}$ \\
\hline Transportation and logistics & $\begin{array}{c}-0.209^{* * *} \\
(0.070)\end{array}$ & $\begin{array}{c}-0.192^{* * *} \\
(0.070)\end{array}$ & $\begin{array}{l}-0.022 \\
(0.052)\end{array}$ & $\begin{array}{l}-0.003 \\
(0.042)\end{array}$ & $\begin{array}{l}-0.074^{*} \\
(0.041)\end{array}$ & $\begin{array}{l}-0.057 \\
(0.035)\end{array}$ \\
\hline Sales less than $\$ 50,000$ & $\begin{array}{c}0.008 \\
(0.052)\end{array}$ & $\begin{array}{c}0.039 \\
(0.055)\end{array}$ & $\begin{array}{l}-0.015 \\
(0.043)\end{array}$ & $\begin{array}{l}-0.010 \\
(0.028)\end{array}$ & $\begin{array}{l}-0.003 \\
(0.024)\end{array}$ & $\begin{array}{l}-0.016 \\
(0.025)\end{array}$ \\
\hline Sales between $\$ 50,000$ - $\$ 999,999$ & $\begin{array}{l}-0.008 \\
(0.054)\end{array}$ & $\begin{array}{c}0.006 \\
(0.058)\end{array}$ & $\begin{array}{c}-0.079^{*} \\
(0.045)\end{array}$ & $\begin{array}{c}0.037 \\
(0.030)\end{array}$ & $\begin{array}{c}0.018 \\
(0.026)\end{array}$ & $\begin{array}{l}-0.009 \\
(0.026)\end{array}$ \\
\hline Sales $\$ 1,000,000$ or more & $\begin{array}{l}-0.089 \\
(0.057)\end{array}$ & $\begin{array}{c}-0.166^{* * *} \\
(0.060)\end{array}$ & $\begin{array}{c}-0.126^{* * *} \\
(0.047)\end{array}$ & $\begin{array}{c}0.129^{* * *} \\
(0.034)\end{array}$ & $\begin{array}{c}0.019 \\
(0.028)\end{array}$ & $\begin{array}{c}0.010 \\
(0.028)\end{array}$ \\
\hline $\begin{array}{l}\text { In-person interactions - Half } \\
\text { or less }\end{array}$ & $\begin{array}{l}-0.020 \\
(0.018)\end{array}$ & $\begin{array}{c}0.002 \\
(0.018)\end{array}$ & $\begin{array}{l}-0.022^{*} \\
(0.012)\end{array}$ & $\begin{array}{l}-0.011 \\
(0.011)\end{array}$ & $\begin{array}{l}0.020^{* *} \\
(0.010)\end{array}$ & $\begin{array}{l}-0.030^{* * *} \\
(0.009)\end{array}$ \\
\hline Male-owned or managed & $\begin{array}{l}0.030^{*} \\
(0.017) \\
\end{array}$ & $\begin{array}{c}0.081^{* * *} \\
(0.017)\end{array}$ & $\begin{array}{c}0.015 \\
(0.012) \\
\end{array}$ & $\begin{array}{c}-0.019^{*} \\
(0.010)\end{array}$ & $\begin{array}{r}0.015 \\
(0.009) \\
\end{array}$ & $\begin{array}{l}-0.013 \\
(0.009) \\
\end{array}$ \\
\hline $\begin{array}{l}\text { Obs. } \\
R^{2}\end{array}$ & $\begin{array}{l}3,476 \\
0.015\end{array}$ & $\begin{array}{l}3,476 \\
0.039\end{array}$ & $\begin{array}{l}3,476 \\
0.017\end{array}$ & $\begin{array}{l}3,476 \\
0.033\end{array}$ & $\begin{array}{l}3,476 \\
0.009\end{array}$ & $\begin{array}{l}3,476 \\
0.025\end{array}$ \\
\hline
\end{tabular}




\section{Table 14: Business Financial Condition}

This table looks at how the financial condition of businesses vary by firm and owner characteristics. In Column 1, businesses were asked "In the past 30 days, which of the following best describes the cash flow situation for this business?". The dependent variable takes a value of one if the response was "Outflow is greater than inflow". In Column 2, businesses were asked "How do you feel about the cash situation for this business over the next 3 months?". The dependent variable takes a value of one if the response was "I am very concerned". In Column 3, businesses were asked "How, if at all, did this business change the average prices it charges for its goods or services during the past 30 days?". The dependent variable takes a value of one if the response was "Decreased prices". The omitted base groups are age - less than 1 year, industry - agriculture or mining, sales - business not operational in 2019, in-person interactions - more than half of the interactions are in-person, and gender - female-owned or managed. Other variables are as defined in Table 3.

\begin{tabular}{|c|c|c|c|}
\hline & $\begin{array}{c}(1) \\
\text { Outflow }>\text { Inflow }\end{array}$ & $\begin{array}{l}\text { (2) } \\
\text { Very concerned } \\
\text { future cashflow }\end{array}$ & $\begin{array}{c}\text { (3) } \\
\text { Decreased } \\
\text { product price }\end{array}$ \\
\hline Age - Between 1 and 2 years & $\begin{array}{c}0.026 \\
(0.043)\end{array}$ & $\begin{array}{c}0.000 \\
(0.041)\end{array}$ & $\begin{array}{c}0.033 \\
(0.039)\end{array}$ \\
\hline Age - Between 2 and 5 years & $\begin{array}{l}-0.009 \\
(0.039)\end{array}$ & $\begin{array}{c}0.034 \\
(0.038)\end{array}$ & $\begin{array}{l}-0.013 \\
(0.036)\end{array}$ \\
\hline Age -5 years or more & $\begin{array}{l}-0.023 \\
(0.037)\end{array}$ & $\begin{array}{l}-0.003 \\
(0.036)\end{array}$ & $\begin{array}{l}-0.048 \\
(0.033)\end{array}$ \\
\hline Construction & $\begin{array}{c}0.095 \\
(0.066)\end{array}$ & $\begin{array}{c}0.038 \\
(0.063)\end{array}$ & $\begin{array}{c}0.029 \\
(0.055)\end{array}$ \\
\hline Hotels, cafes, and restaurants & $\begin{array}{c}0.072 \\
(0.066)\end{array}$ & $\begin{array}{c}0.188^{* * *} \\
(0.063)\end{array}$ & $\begin{array}{c}0.072 \\
(0.056)\end{array}$ \\
\hline Information and communication & $\begin{array}{l}-0.005 \\
(0.062)\end{array}$ & $\begin{array}{c}0.005 \\
(0.059)\end{array}$ & $\begin{array}{c}0.048 \\
(0.053)\end{array}$ \\
\hline Manufacturing & $\begin{array}{l}-0.018 \\
(0.074)\end{array}$ & $\begin{array}{c}0.095 \\
(0.071)\end{array}$ & $\begin{array}{l}-0.011 \\
(0.061)\end{array}$ \\
\hline Other & $\begin{array}{c}0.012 \\
(0.058)\end{array}$ & $\begin{array}{c}0.064 \\
(0.056)\end{array}$ & $\begin{array}{l}-0.012 \\
(0.049)\end{array}$ \\
\hline Retail and wholesale trade & $\begin{array}{l}-0.023 \\
(0.058)\end{array}$ & $\begin{array}{c}0.047 \\
(0.056)\end{array}$ & $\begin{array}{c}0.037 \\
(0.049)\end{array}$ \\
\hline Services & $\begin{array}{c}0.024 \\
(0.057)\end{array}$ & $\begin{array}{c}0.066 \\
(0.054)\end{array}$ & $\begin{array}{c}0.051 \\
(0.048)\end{array}$ \\
\hline Transportation and logistics & $\begin{array}{c}0.063 \\
(0.075)\end{array}$ & $\begin{array}{l}0.144^{* *} \\
(0.072)\end{array}$ & $\begin{array}{l}0.148^{* *} \\
(0.066)\end{array}$ \\
\hline Sales less than $\$ 50,000$ & $\begin{array}{c}0.012 \\
(0.055)\end{array}$ & $\begin{array}{l}-0.002 \\
(0.054)\end{array}$ & $\begin{array}{l}0.110^{* *} \\
(0.044)\end{array}$ \\
\hline Sales between $\$ 50,000$ - $\$ 999,999$ & $\begin{array}{c}0.041 \\
(0.057)\end{array}$ & $\begin{array}{c}0.043 \\
(0.056)\end{array}$ & $\begin{array}{l}0.099^{* *} \\
(0.047)\end{array}$ \\
\hline Sales $\$ 1,000,000$ or more & $\begin{array}{l}-0.028 \\
(0.060)\end{array}$ & $\begin{array}{c}-0.105^{*} \\
(0.059)\end{array}$ & $\begin{array}{c}0.054 \\
(0.049)\end{array}$ \\
\hline $\begin{array}{l}\text { In-person interactions - Half } \\
\text { or less }\end{array}$ & $\begin{array}{l}-0.096^{* * *} \\
(0.018)\end{array}$ & $\begin{array}{l}-0.121^{* * *} \\
(0.018)\end{array}$ & $\begin{array}{c}0.011 \\
(0.016)\end{array}$ \\
\hline Male-owned or managed & $\begin{array}{l}-0.002 \\
(0.018)\end{array}$ & $\begin{array}{l}-0.010 \\
(0.017)\end{array}$ & $\begin{array}{c}0.001 \\
(0.015)\end{array}$ \\
\hline $\begin{array}{l}\text { Obs. } \\
R^{2}\end{array}$ & $\begin{array}{l}3,450 \\
0.017\end{array}$ & $\begin{array}{l}3,468 \\
0.037\end{array}$ & $\begin{array}{l}3,461 \\
0.015\end{array}$ \\
\hline
\end{tabular}




\section{Table 15: Business and Household Struggles}

This table looks at how ease of conducting business and household activities vary by firm and owner characteristics. In Column 1, the dependent variable takes a value of one if the respondent replied "A lot" or "A great deal" to "How much have your household responsibilities affected your ability to focus on this business during the coronavirus (COVID-19) pandemic?". In Column 2, the dependent variable takes a value of one if the respondent replied "A lot" or "A great deal" to "How much have your business responsibilities affected your ability to take care of your household during the coronavirus (COVID-19) pandemic?". Other variables are as defined in Table 3.

\begin{tabular}{|c|c|c|}
\hline & $\begin{array}{c}\text { (1) } \\
\text { Difficulty in } \\
\text { conducting business }\end{array}$ & $\begin{array}{c}\text { (2) } \\
\text { Difficulty in } \\
\text { caring for household }\end{array}$ \\
\hline Age - Between 1 and 2 years & $\begin{array}{c}0.009 \\
(0.041)\end{array}$ & $\begin{array}{l}-0.068^{*} \\
(0.038)\end{array}$ \\
\hline Age - Between 2 and 5 years & $\begin{array}{c}0.004 \\
(0.038)\end{array}$ & $\begin{array}{l}-0.054 \\
(0.036)\end{array}$ \\
\hline Age - 5 years or more & $\begin{array}{l}-0.064^{*} \\
(0.036)\end{array}$ & $\begin{array}{l}-0.099^{* * *} \\
(0.034)\end{array}$ \\
\hline Construction & $\begin{array}{c}0.020 \\
(0.051)\end{array}$ & $\begin{array}{l}0.094^{*} \\
(0.049)\end{array}$ \\
\hline Hotels, cafes, and restaurants & $\begin{array}{l}0.113^{* *} \\
(0.052)\end{array}$ & $\begin{array}{c}0.251^{* * *} \\
(0.051)\end{array}$ \\
\hline Information and communication & $\begin{array}{c}0.076 \\
(0.050)\end{array}$ & $\begin{array}{l}0.085^{*} \\
(0.046)\end{array}$ \\
\hline Manufacturing & $\begin{array}{c}0.055 \\
(0.055)\end{array}$ & $\begin{array}{c}0.073 \\
(0.053)\end{array}$ \\
\hline Other & $\begin{array}{c}0.036 \\
(0.044)\end{array}$ & $\begin{array}{l}0.085^{* *} \\
(0.041)\end{array}$ \\
\hline Retail and wholesale trade & $\begin{array}{c}0.039 \\
(0.044)\end{array}$ & $\begin{array}{l}0.096^{* *} \\
(0.041)\end{array}$ \\
\hline Services & $\begin{array}{c}0.069 \\
(0.043)\end{array}$ & $\begin{array}{l}0.108^{* * *} \\
(0.040)\end{array}$ \\
\hline Transportation and logistics & $\begin{array}{l}0.106^{*} \\
(0.062)\end{array}$ & $\begin{array}{l}0.143^{* *} \\
(0.061)\end{array}$ \\
\hline Sales less than $\$ 50,000$ & $\begin{array}{l}-0.006 \\
(0.051)\end{array}$ & $\begin{array}{l}0.099^{* *} \\
(0.046)\end{array}$ \\
\hline Sales between $\$ 50,000$ - $\$ 999,999$ & $\begin{array}{l}-0.014 \\
(0.054)\end{array}$ & $\begin{array}{c}0.151^{* * *} \\
(0.049)\end{array}$ \\
\hline Sales $\$ 1,000,000$ or more & $\begin{array}{l}-0.067 \\
(0.055)\end{array}$ & $\begin{array}{l}0.152^{* * *} \\
(0.050)\end{array}$ \\
\hline $\begin{array}{l}\text { In-person interactions - Half } \\
\text { or less }\end{array}$ & $\begin{array}{l}-0.016 \\
(0.018)\end{array}$ & $\begin{array}{c}-0.043^{* *} \\
(0.017)\end{array}$ \\
\hline Male-owned or managed & $\begin{array}{l}-0.046^{* * *} \\
(0.016)\end{array}$ & $\begin{array}{l}-0.029^{*} \\
(0.016)\end{array}$ \\
\hline Remote work - Sometimes & $\begin{array}{c}0.052^{* * *} \\
(0.019)\end{array}$ & $\begin{array}{c}0.017 \\
(0.018)\end{array}$ \\
\hline Remote work - Not at all & $\begin{array}{l}-0.033 \\
(0.024) \\
\end{array}$ & $\begin{array}{c}0.018 \\
(0.024) \\
\end{array}$ \\
\hline $\begin{array}{l}\text { Obs. } \\
R^{2}\end{array}$ & $\begin{array}{l}3,568 \\
0.023\end{array}$ & $\begin{array}{l}3,567 \\
0.021\end{array}$ \\
\hline
\end{tabular}




\section{Table 16: Time Spent on Business and Household Activities}

This table looks at how time spent on activities by business owners and managers vary by firm and owner characteristics. Businesses were asked "Which of the following have you personally had to spend more time on since the beginning of the coronavirus (COVID-19) pandemic?". The dependent variable takes a value of one if the response is "Business work" (Column 1), "Housework or homemaking" (Column 2), "Daycare for children in your household" (Column 3), or "Education for school-aged children in your household" (Column 4). Respondents could select multiple options. In Column 5 , the dependent variable is the response in number of hours to the question "On average, how many hours per day are you spending on domestic or household care activities?". The omitted base groups are age - less than 1 year, industry - agriculture or mining, sales - business not operational in 2019, inperson interactions - more than half of the interactions are in-person, and gender - female-owned or managed. Other variables are as defined in Table 3.

\begin{tabular}{|c|c|c|c|c|c|}
\hline & $\begin{array}{c}\text { (1) } \\
\text { Business } \\
\text { work } \\
\end{array}$ & $\begin{array}{c}(2) \\
\begin{array}{c}\text { Household } \\
\text { work }\end{array} \\
\end{array}$ & $\begin{array}{c}(3) \\
\text { Daycare } \\
\text { for children } \\
\end{array}$ & $\begin{array}{c}\text { (4) } \\
\text { Education } \\
\text { for children } \\
\end{array}$ & $\begin{array}{c}\text { (5) } \\
\text { Hours spent on } \\
\text { Household work } \\
\end{array}$ \\
\hline Age - Between 1 and 2 years & $\begin{array}{l}-0.005 \\
(0.039)\end{array}$ & $\begin{array}{c}0.043 \\
(0.039)\end{array}$ & $\begin{array}{c}0.017 \\
(0.031)\end{array}$ & $\begin{array}{l}-0.026 \\
(0.037)\end{array}$ & $\begin{array}{l}-0.080 \\
(0.245)\end{array}$ \\
\hline Age - Between 2 and 5 years & $\begin{array}{c}0.012 \\
(0.037)\end{array}$ & $\begin{array}{c}0.006 \\
(0.036)\end{array}$ & $\begin{array}{l}-0.020 \\
(0.029)\end{array}$ & $\begin{array}{l}-0.004 \\
(0.034)\end{array}$ & $\begin{array}{c}0.039 \\
(0.233)\end{array}$ \\
\hline Age - 5 years or more & $\begin{array}{l}-0.017 \\
(0.035)\end{array}$ & $\begin{array}{l}-0.041 \\
(0.034)\end{array}$ & $\begin{array}{c}-0.079^{* * *} \\
(0.026)\end{array}$ & $\begin{array}{c}-0.068^{* *} \\
(0.032)\end{array}$ & $\begin{array}{l}-0.256 \\
(0.223)\end{array}$ \\
\hline Construction & $\begin{array}{c}0.031 \\
(0.056)\end{array}$ & $\begin{array}{c}0.082 \\
(0.054)\end{array}$ & $\begin{array}{l}-0.036 \\
(0.040)\end{array}$ & $\begin{array}{l}0.099^{* *} \\
(0.050)\end{array}$ & $\begin{array}{l}-0.342 \\
(0.337)\end{array}$ \\
\hline Hotels, cafes, and restaurants & $\begin{array}{c}0.198^{* * *} \\
(0.054)\end{array}$ & $\begin{array}{c}0.010 \\
(0.053)\end{array}$ & $\begin{array}{l}-0.027 \\
(0.039)\end{array}$ & $\begin{array}{c}0.042 \\
(0.048)\end{array}$ & $\begin{array}{l}-0.468 \\
(0.344)\end{array}$ \\
\hline Information and communication & $\begin{array}{c}0.148^{* * *} \\
(0.052)\end{array}$ & $\begin{array}{c}0.078 \\
(0.052)\end{array}$ & $\begin{array}{c}0.012 \\
(0.039)\end{array}$ & $\begin{array}{c}0.051 \\
(0.047)\end{array}$ & $\begin{array}{l}-0.221 \\
(0.334)\end{array}$ \\
\hline Manufacturing & $\begin{array}{l}0.148^{* *} \\
(0.059)\end{array}$ & $\begin{array}{c}0.029 \\
(0.059)\end{array}$ & $\begin{array}{l}-0.063 \\
(0.041)\end{array}$ & $\begin{array}{c}0.063 \\
(0.054)\end{array}$ & $\begin{array}{l}-0.224 \\
(0.374)\end{array}$ \\
\hline Other & $\begin{array}{c}0.147^{* * * *} \\
(0.047)\end{array}$ & $\begin{array}{c}0.126^{* * * *} \\
(0.046)\end{array}$ & $\begin{array}{c}0.006 \\
(0.035)\end{array}$ & $\begin{array}{l}0.092^{* *} \\
(0.041)\end{array}$ & $\begin{array}{l}-0.218 \\
(0.309)\end{array}$ \\
\hline Retail and wholesale trade & $\begin{array}{l}0.104^{* *} \\
(0.047)\end{array}$ & $\begin{array}{c}0.049 \\
(0.046)\end{array}$ & $\begin{array}{c}0.003 \\
(0.035)\end{array}$ & $\begin{array}{c}0.064 \\
(0.042)\end{array}$ & $\begin{array}{l}-0.197 \\
(0.312)\end{array}$ \\
\hline Services & $\begin{array}{l}0.104^{* *} \\
(0.046)\end{array}$ & $\begin{array}{l}0.091^{* *} \\
(0.045)\end{array}$ & $\begin{array}{c}0.023 \\
(0.034)\end{array}$ & $\begin{array}{l}0.085^{* *} \\
(0.041)\end{array}$ & $\begin{array}{l}-0.128 \\
(0.305)\end{array}$ \\
\hline Transportation and logistics & $\begin{array}{c}0.069 \\
(0.065)\end{array}$ & $\begin{array}{c}0.070 \\
(0.064)\end{array}$ & $\begin{array}{c}0.037 \\
(0.051)\end{array}$ & $\begin{array}{l}0.103^{*} \\
(0.059)\end{array}$ & $\begin{array}{c}0.370 \\
(0.416)\end{array}$ \\
\hline Sales less than $\$ 50,000$ & $\begin{array}{l}-0.043 \\
(0.049)\end{array}$ & $\begin{array}{c}0.009 \\
(0.049)\end{array}$ & $\begin{array}{l}-0.024 \\
(0.038)\end{array}$ & $\begin{array}{c}-0.092^{* *} \\
(0.047)\end{array}$ & $\begin{array}{l}-0.436 \\
(0.338)\end{array}$ \\
\hline Sales between $\$ 50,000$ - $\$ 999,999$ & $\begin{array}{c}0.075 \\
(0.051)\end{array}$ & $\begin{array}{l}-0.010 \\
(0.051)\end{array}$ & $\begin{array}{c}0.033 \\
(0.040)\end{array}$ & $\begin{array}{l}-0.020 \\
(0.050)\end{array}$ & $\begin{array}{c}-0.587^{*} \\
(0.356)\end{array}$ \\
\hline Sales $\$ 1,000,000$ or more & $\begin{array}{c}0.081 \\
(0.053)\end{array}$ & $\begin{array}{l}-0.007 \\
(0.053)\end{array}$ & $\begin{array}{c}0.066 \\
(0.041)\end{array}$ & $\begin{array}{c}0.011 \\
(0.051)\end{array}$ & $\begin{array}{c}-0.860^{* *} \\
(0.364)\end{array}$ \\
\hline $\begin{array}{l}\text { In-person interactions - Half } \\
\text { or less }\end{array}$ & $\begin{array}{c}0.013 \\
(0.017)\end{array}$ & $\begin{array}{c}0.053^{* * *} \\
(0.017)\end{array}$ & $\begin{array}{l}0.027^{* *} \\
(0.013)\end{array}$ & $\begin{array}{c}0.026 \\
(0.016)\end{array}$ & $\begin{array}{l}-0.372^{* * *} \\
(0.101)\end{array}$ \\
\hline Male-owned or managed & $\begin{array}{c}0.006 \\
(0.016) \\
\end{array}$ & $\begin{array}{c}-0.164^{* * *} \\
(0.016) \\
\end{array}$ & $\begin{array}{c}-0.024^{*} \\
(0.012) \\
\end{array}$ & $\begin{array}{c}-0.107^{* * *} \\
(0.015) \\
\end{array}$ & $\begin{array}{l}-0.402 * * * \\
(0.092) \\
\end{array}$ \\
\hline $\begin{array}{l}\text { Obs. } \\
R^{2}\end{array}$ & $\begin{array}{l}3,931 \\
0.020\end{array}$ & $\begin{array}{l}3,931 \\
0.044\end{array}$ & $\begin{array}{l}3,931 \\
0.014\end{array}$ & $\begin{array}{l}3,931 \\
0.022\end{array}$ & $\begin{array}{l}3,954 \\
0.020\end{array}$ \\
\hline
\end{tabular}


Table 17: Business Employees

This table looks at how business and owner characteristics affect the employees of the business. In Column 1, the dependent variable takes a value of one if the respondent replied "More than half" or "All" to "During the coronavirus (COVID-19) pandemic, how many of this business's employees/workers could work from home for more than a few days?". In Column 2, the dependent variable takes a value of one if the respondent replied "Yes, for all employees/workers" to "Does this business allow employees/workers to take resources or equipment home with them to support working from home?". In Column 3, the dependent variable takes a value of one if the respondent replied "High" to "How would you rate the potential for exposure of the employees/workers of this business to coronavirus (COVID-19) infection while working?". In Column 4, the dependent variable takes a value of one if the respondent replied in the affirmative to any of the options to "Does the business pay any of the following totally or partially to its employees/workers during the current circumstances?". The omitted base groups are age - less than 1 year, industry - agriculture or mining, sales - business not operational in 2019, in-person interactions - more than half of the interactions are in-person, and gender - female-owned or managed. Other variables are as defined in Table 3.

\begin{tabular}{|c|c|c|c|c|}
\hline & Work from home & $\begin{array}{c}\text { (2) } \\
\text { Support for } \\
\text { work from home }\end{array}$ & $\begin{array}{l}\text { (3) } \\
\text { High exposure } \\
\text { risk }\end{array}$ & $\begin{array}{c}(4) \\
\text { Employee } \\
\text { compensation }\end{array}$ \\
\hline Age - Between 1 and 2 years & $\begin{array}{c}0.022 \\
(0.056)\end{array}$ & $\begin{array}{c}0.039 \\
(0.088)\end{array}$ & $\begin{array}{l}-0.007 \\
(0.043)\end{array}$ & $\begin{array}{c}-0.013 \\
(0.053)\end{array}$ \\
\hline Age - Between 2 and 5 years & $\begin{array}{c}0.057 \\
(0.055)\end{array}$ & $\begin{array}{c}0.032 \\
(0.083)\end{array}$ & $\begin{array}{l}-0.017 \\
(0.040)\end{array}$ & $\begin{array}{l}-0.011 \\
(0.052)\end{array}$ \\
\hline Age - 5 years or more & $\begin{array}{l}-0.049 \\
(0.052)\end{array}$ & $\begin{array}{l}-0.063 \\
(0.080)\end{array}$ & $\begin{array}{c}0.003 \\
(0.039)\end{array}$ & $\begin{array}{l}0.120^{* *} \\
(0.049)\end{array}$ \\
\hline Construction & $\begin{array}{c}0.017 \\
(0.056)\end{array}$ & $\begin{array}{l}-0.128 \\
(0.104)\end{array}$ & $\begin{array}{l}-0.060 \\
(0.040)\end{array}$ & $\begin{array}{c}-0.032 \\
(0.053)\end{array}$ \\
\hline Hotels, cafes, and restaurants & $\begin{array}{c}0.025 \\
(0.052)\end{array}$ & $\begin{array}{c}-0.266^{* *} \\
(0.108)\end{array}$ & $\begin{array}{l}-0.003 \\
(0.044)\end{array}$ & $\begin{array}{c}-0.129^{* *} \\
(0.052)\end{array}$ \\
\hline Information and communication & $\begin{array}{c}0.557^{* * *} \\
(0.056)\end{array}$ & $\begin{array}{c}0.062 \\
(0.095)\end{array}$ & $\begin{array}{c}-0.016 \\
(0.039)\end{array}$ & $\begin{array}{l}0.093^{*} \\
(0.055)\end{array}$ \\
\hline Manufacturing & $\begin{array}{c}-0.004 \\
(0.063)\end{array}$ & $\begin{array}{c}-0.328^{* * *} \\
(0.099)\end{array}$ & $\begin{array}{c}-0.074^{*} \\
(0.042)\end{array}$ & $\begin{array}{c}0.040 \\
(0.061)\end{array}$ \\
\hline Other & $\begin{array}{c}0.363^{* * *} \\
(0.052)\end{array}$ & $\begin{array}{c}0.017 \\
(0.091)\end{array}$ & $\begin{array}{c}0.050 \\
(0.038)\end{array}$ & $\begin{array}{l}0.080^{*} \\
(0.047)\end{array}$ \\
\hline Retail and wholesale trade & $\begin{array}{c}0.139 * * * \\
(0.053)\end{array}$ & $\begin{array}{l}-0.116 \\
(0.093)\end{array}$ & $\begin{array}{c}0.023 \\
(0.039)\end{array}$ & $\begin{array}{c}0.016 \\
(0.048)\end{array}$ \\
\hline Services & $\begin{array}{c}0.344^{* * *} \\
(0.051)\end{array}$ & $\begin{array}{c}0.040 \\
(0.090)\end{array}$ & $\begin{array}{l}-0.010 \\
(0.037)\end{array}$ & $\begin{array}{c}0.043 \\
(0.046)\end{array}$ \\
\hline Transportation and logistics & $\begin{array}{c}0.039 \\
(0.060)\end{array}$ & $\begin{array}{c}-0.253^{* *} \\
(0.106)\end{array}$ & $\begin{array}{c}0.053 \\
(0.054)\end{array}$ & $\begin{array}{l}-0.026 \\
(0.062)\end{array}$ \\
\hline Sales less than $\$ 50,000$ & $\begin{array}{c}0.065 \\
(0.082)\end{array}$ & $\begin{array}{c}-0.004 \\
(0.110)\end{array}$ & $\begin{array}{c}-0.003 \\
(0.056)\end{array}$ & $\begin{array}{l}-0.005 \\
(0.062)\end{array}$ \\
\hline Sales between $\$ 50,000$ - $\$ 999,999$ & $\begin{array}{l}-0.002 \\
(0.084)\end{array}$ & $\begin{array}{c}-0.061 \\
(0.114)\end{array}$ & $\begin{array}{c}0.004 \\
(0.058)\end{array}$ & $\begin{array}{c}0.221^{* * *} \\
(0.067)\end{array}$ \\
\hline Sales $\$ 1,000,000$ or more & $\begin{array}{c}0.031 \\
(0.085)\end{array}$ & $\begin{array}{c}-0.137 \\
(0.115)\end{array}$ & $\begin{array}{c}0.071 \\
(0.060)\end{array}$ & $\begin{array}{c}0.566^{* * *} \\
(0.068)\end{array}$ \\
\hline $\begin{array}{l}\text { In-person interactions - Half } \\
\text { or less }\end{array}$ & $\begin{array}{c}0.326^{* * *} \\
(0.018)\end{array}$ & $\begin{array}{c}0.238^{* * *} \\
(0.027)\end{array}$ & $\begin{array}{c}-0.162^{* * *} \\
(0.015)\end{array}$ & $\begin{array}{l}0.065^{* * *} \\
(0.019)\end{array}$ \\
\hline Male-owned or managed & $\begin{array}{c}-0.076^{* * *} \\
(0.017) \\
\end{array}$ & $\begin{array}{c}0.032 \\
(0.025) \\
\end{array}$ & $\begin{array}{c}-0.031^{* *} \\
(0.014)\end{array}$ & $\begin{array}{c}0.002 \\
(0.018) \\
\end{array}$ \\
\hline $\begin{array}{l}\text { Obs. } \\
R^{2}\end{array}$ & $\begin{array}{l}2,435 \\
0.297\end{array}$ & $\begin{array}{l}1,513 \\
0.141\end{array}$ & $\begin{array}{l}2,438 \\
0.085\end{array}$ & $\begin{array}{l}2,423 \\
0.244\end{array}$ \\
\hline
\end{tabular}




\section{Table 18: Client Accommodation}

This table looks at changes implemented by businesses to accommodate their customers. Businesses were asked "Did this business have to change anything to accommodate its clients or customers during the coronavirus (COVID-19) pandemic?". The dependent variable takes a value of one if the response is "Provide online services" (Column 1), "Expand use of digital payments" (Column 2), "Provide delivery of servides or goods at home" (Column 3), or "Provide curbside delivery at business location" (Column 4). Respondents could select multiple options. The omitted base groups are age - less than 1 year, industry - agriculture or mining, sales - business not operational in 2019, in-person interactions - more than half of the interactions are in-person, and gender female-owned or managed. Other variables are as defined in Table 3.

\begin{tabular}{|c|c|c|c|c|}
\hline & $\begin{array}{c}\text { (1) } \\
\text { Provide } \\
\text { online services }\end{array}$ & $\begin{array}{c}\text { (2) } \\
\text { Expanded use of } \\
\text { digital payment }\end{array}$ & $\begin{array}{c}\text { (3) } \\
\text { Provide } \\
\text { delivery services }\end{array}$ & $\begin{array}{c}(4) \\
\text { Provide } \\
\text { curbside pickup }\end{array}$ \\
\hline Age - Between 1 and 2 years & $\begin{array}{c}0.005 \\
(0.047)\end{array}$ & $\begin{array}{l}-0.019 \\
(0.047)\end{array}$ & $\begin{array}{l}-0.019 \\
(0.042)\end{array}$ & $\begin{array}{l}-0.052 \\
(0.036)\end{array}$ \\
\hline Age - Between 2 and 5 years & $\begin{array}{l}-0.020 \\
(0.044)\end{array}$ & $\begin{array}{l}-0.098^{* *} \\
(0.043)\end{array}$ & $\begin{array}{l}-0.040 \\
(0.040)\end{array}$ & $\begin{array}{l}-0.046 \\
(0.034)\end{array}$ \\
\hline Age -5 years or more & $\begin{array}{l}-0.031 \\
(0.041)\end{array}$ & $\begin{array}{l}-0.088^{* *} \\
(0.041)\end{array}$ & $\begin{array}{l}-0.036 \\
(0.038)\end{array}$ & $\begin{array}{l}-0.029 \\
(0.032)\end{array}$ \\
\hline Construction & $\begin{array}{l}-0.077 \\
(0.065)\end{array}$ & $\begin{array}{l}-0.104 \\
(0.069)\end{array}$ & $\begin{array}{l}-0.108^{*} \\
(0.061)\end{array}$ & $\begin{array}{l}-0.200^{* * *} \\
(0.060)\end{array}$ \\
\hline Hotels, cafes, and restaurants & $\begin{array}{c}0.017 \\
(0.063)\end{array}$ & $\begin{array}{c}0.046 \\
(0.067)\end{array}$ & $\begin{array}{l}0.152^{* *} \\
(0.063)\end{array}$ & $\begin{array}{l}0.439^{* * *} \\
(0.061)\end{array}$ \\
\hline Information and communication & $\begin{array}{c}0.329^{* * *} \\
(0.065)\end{array}$ & $\begin{array}{l}-0.106 \\
(0.068)\end{array}$ & $\begin{array}{c}-0.093 \\
(0.061)\end{array}$ & $\begin{array}{c}-0.210^{* * *} \\
(0.058)\end{array}$ \\
\hline Manufacturing & $\begin{array}{c}0.068 \\
(0.080)\end{array}$ & $\begin{array}{l}-0.256^{* * *} \\
(0.075)\end{array}$ & $\begin{array}{l}-0.128^{*} \\
(0.069)\end{array}$ & $\begin{array}{l}-0.079 \\
(0.074)\end{array}$ \\
\hline Other & $\begin{array}{c}0.229^{* * *} \\
(0.058)\end{array}$ & $\begin{array}{c}-0.143^{* *} \\
(0.060)\end{array}$ & $\begin{array}{l}-0.085 \\
(0.055)\end{array}$ & $\begin{array}{c}-0.166^{* * *} \\
(0.056)\end{array}$ \\
\hline Retail and wholesale trade & $\begin{array}{c}0.163^{* * *} \\
(0.059)\end{array}$ & $\begin{array}{c}-0.039 \\
(0.062)\end{array}$ & $\begin{array}{c}0.156^{* * *} \\
(0.058)\end{array}$ & $\begin{array}{l}0.137^{* *} \\
(0.059)\end{array}$ \\
\hline Services & $\begin{array}{c}0.235^{* * *} \\
(0.057)\end{array}$ & $\begin{array}{l}-0.116^{*} \\
(0.060)\end{array}$ & $\begin{array}{l}-0.064 \\
(0.055)\end{array}$ & $\begin{array}{l}-0.149^{* * *} \\
(0.056)\end{array}$ \\
\hline Transportation and logistics & $\begin{array}{c}0.003 \\
(0.077)\end{array}$ & $\begin{array}{l}-0.128 \\
(0.078)\end{array}$ & $\begin{array}{l}-0.035 \\
(0.072)\end{array}$ & $\begin{array}{c}-0.116^{*} \\
(0.070)\end{array}$ \\
\hline Sales less than $\$ 50,000$ & $\begin{array}{c}0.012 \\
(0.064)\end{array}$ & $\begin{array}{c}0.021 \\
(0.062)\end{array}$ & $\begin{array}{l}-0.045 \\
(0.059)\end{array}$ & $\begin{array}{c}0.014 \\
(0.050)\end{array}$ \\
\hline Sales between $\$ 50,000$ - $\$ 999,999$ & $\begin{array}{c}0.016 \\
(0.067)\end{array}$ & $\begin{array}{c}0.054 \\
(0.064)\end{array}$ & $\begin{array}{l}-0.057 \\
(0.061)\end{array}$ & $\begin{array}{c}0.025 \\
(0.052)\end{array}$ \\
\hline Sales $\$ 1,000,000$ or more & $\begin{array}{c}0.029 \\
(0.069)\end{array}$ & $\begin{array}{c}0.045 \\
(0.066)\end{array}$ & $\begin{array}{l}-0.026 \\
(0.063)\end{array}$ & $\begin{array}{c}0.071 \\
(0.053)\end{array}$ \\
\hline $\begin{array}{l}\text { In-person interactions - Half } \\
\text { or less }\end{array}$ & $\begin{array}{c}0.020 \\
(0.019)\end{array}$ & $\begin{array}{l}-0.028 \\
(0.018)\end{array}$ & $\begin{array}{l}-0.051^{* * *} \\
(0.017)\end{array}$ & $\begin{array}{l}-0.118^{* * *} \\
(0.015)\end{array}$ \\
\hline Male-owned or managed & $\begin{array}{l}-0.058^{* * *} \\
(0.019)\end{array}$ & $\begin{array}{l}-0.011 \\
(0.018)\end{array}$ & $\begin{array}{c}0.001 \\
(0.017)\end{array}$ & $\begin{array}{l}-0.020 \\
(0.014)\end{array}$ \\
\hline $\begin{array}{l}\text { Obs. } \\
R^{2}\end{array}$ & $\begin{array}{l}2,926 \\
0.050\end{array}$ & $\begin{array}{l}2,926 \\
0.022\end{array}$ & $\begin{array}{l}2,926 \\
0.062\end{array}$ & $\begin{array}{l}2,926 \\
0.229\end{array}$ \\
\hline
\end{tabular}




\section{Table 19: Business Model Changes}

This table looks at changes businesses made to their business model and difficulties in doing so. The first two columns relate to the question "Which of the following has this business used in the past 30 days to continue operating during the pandemic?". The dependent variable takes a value of one if the respondent stated "Online advertising" (Column 1) or "Digital payment tools" (Column 2). The following two columns relate to the question "Which of the following changes has this business made to assure needed supplies are available during the pandemic?" and take a value of one if the respondent stated "Adjusted order schedules" (Column 3) or "Changed delivery processes" (Column 4). Column 5 takes a value of one if the respondent stated "Difficult" or "Very difficult" as a response to "How easy or difficult is it for this business to change the delivery of goods or services as a result of the pandemic?". Column 6 takes a value of one if the respondent stated "Yes, I have sufficient information" as a response to "Do you feel that you have access to enough information to make decisions about this business during pandemic?". The omitted base groups are age - less than 1 year, industry agriculture or mining, sales - business not operational in 2019, in-person interactions - more than half of the interactions are in-person, and gender - female-owned or managed. Other variables are as defined in Table 3.

\begin{tabular}{|c|c|c|c|c|c|c|}
\hline & $\begin{array}{c}\text { (1) } \\
\text { Online } \\
\text { advertising }\end{array}$ & $\begin{array}{c}(2) \\
\text { Digital } \\
\text { payment tools }\end{array}$ & $\begin{array}{c}\text { (3) } \\
\text { Adjusted } \\
\text { order schedules }\end{array}$ & $\begin{array}{c}\text { (4) } \\
\text { Changed } \\
\text { delivery processes }\end{array}$ & $\begin{array}{c}\text { (5) } \\
\text { Difficult to change } \\
\text { delivery processes }\end{array}$ & $\begin{array}{c}6) \\
\text { Sufficient } \\
\text { information }\end{array}$ \\
\hline Age - Between 1 and 2 years & $\begin{array}{l}-0.015 \\
(0.038)\end{array}$ & $\begin{array}{l}-0.014 \\
(0.040)\end{array}$ & $\begin{array}{l}-0.006 \\
(0.005)\end{array}$ & $\begin{array}{l}-0.024 \\
(0.032)\end{array}$ & $\begin{array}{l}-0.046 \\
(0.037)\end{array}$ & $\begin{array}{c}0.100^{* * * *} \\
(0.038)\end{array}$ \\
\hline Age - Between 2 and 5 years & $\begin{array}{l}-0.055 \\
(0.036)\end{array}$ & $\begin{array}{l}-0.050 \\
(0.037)\end{array}$ & $\begin{array}{l}-0.005 \\
(0.005)\end{array}$ & $\begin{array}{c}-0.060^{* *} \\
(0.029)\end{array}$ & $\begin{array}{l}-0.015 \\
(0.035)\end{array}$ & $\begin{array}{c}0.021 \\
(0.037)\end{array}$ \\
\hline Age - 5 years or more & $\begin{array}{c}-0.148^{* * *} \\
(0.034)\end{array}$ & $\begin{array}{c}-0.075^{* *} \\
(0.035)\end{array}$ & $\begin{array}{l}-0.006 \\
(0.004)\end{array}$ & $\begin{array}{l}-0.025 \\
(0.028)\end{array}$ & $\begin{array}{l}-0.007 \\
(0.033)\end{array}$ & $\begin{array}{l}0.082^{* *} \\
(0.034)\end{array}$ \\
\hline Construction & $\begin{array}{c}-0.101^{*} \\
(0.058)\end{array}$ & $\begin{array}{c}-0.111^{* *} \\
(0.056)\end{array}$ & $\begin{array}{l}-0.009 \\
(0.010)\end{array}$ & $\begin{array}{l}-0.071 \\
(0.047)\end{array}$ & $\begin{array}{c}0.046 \\
(0.057)\end{array}$ & $\begin{array}{c}0.078 \\
(0.057)\end{array}$ \\
\hline Hotels, cafes, and restaurants & $\begin{array}{c}0.237^{* * *} \\
(0.057)\end{array}$ & $\begin{array}{l}0.097^{*} \\
(0.057)\end{array}$ & $\begin{array}{c}0.010 \\
(0.010)\end{array}$ & $\begin{array}{l}0.105^{* *} \\
(0.051)\end{array}$ & $\begin{array}{c}0.054 \\
(0.056)\end{array}$ & $\begin{array}{c}0.014 \\
(0.057)\end{array}$ \\
\hline Information and communication & $\begin{array}{c}0.018 \\
(0.057)\end{array}$ & $\begin{array}{l}-0.012 \\
(0.056)\end{array}$ & $\begin{array}{c}-0.018^{* *} \\
(0.009)\end{array}$ & $\begin{array}{c}-0.079^{*} \\
(0.046)\end{array}$ & $\begin{array}{c}-0.120^{* *} \\
(0.053)\end{array}$ & $\begin{array}{c}0.077 \\
(0.055)\end{array}$ \\
\hline Manufacturing & $\begin{array}{l}-0.055 \\
(0.067)\end{array}$ & $\begin{array}{l}-0.089 \\
(0.065)\end{array}$ & $\begin{array}{c}0.016 \\
(0.012)\end{array}$ & $\begin{array}{l}-0.012 \\
(0.057)\end{array}$ & $\begin{array}{c}0.010 \\
(0.064)\end{array}$ & $\begin{array}{c}0.087 \\
(0.063)\end{array}$ \\
\hline Other & $\begin{array}{c}0.060 \\
(0.051)\end{array}$ & $\begin{array}{l}-0.011 \\
(0.050)\end{array}$ & $\begin{array}{c}-0.019^{* *} \\
(0.008)\end{array}$ & $\begin{array}{c}-0.094^{* *} \\
(0.042)\end{array}$ & $\begin{array}{c}0.012 \\
(0.049)\end{array}$ & $\begin{array}{c}0.042 \\
(0.049)\end{array}$ \\
\hline Retail and wholesale trade & $\begin{array}{c}0.184^{* * *} \\
(0.051)\end{array}$ & $\begin{array}{c}0.074 \\
(0.050)\end{array}$ & $\begin{array}{c}0.003 \\
(0.009)\end{array}$ & $\begin{array}{c}0.060 \\
(0.044)\end{array}$ & $\begin{array}{l}-0.025 \\
(0.049)\end{array}$ & $\begin{array}{c}0.030 \\
(0.050)\end{array}$ \\
\hline Services & $\begin{array}{c}0.062 \\
(0.050)\end{array}$ & $\begin{array}{c}0.038 \\
(0.049)\end{array}$ & $\begin{array}{c}-0.021^{* *} \\
(0.008)\end{array}$ & $\begin{array}{l}-0.067 \\
(0.042)\end{array}$ & $\begin{array}{c}0.012 \\
(0.048)\end{array}$ & $\begin{array}{c}0.053 \\
(0.049)\end{array}$ \\
\hline Transportation and logistics & $\begin{array}{c}-0.152^{* *} \\
(0.067)\end{array}$ & $\begin{array}{c}-0.162^{* *} \\
(0.064)\end{array}$ & $\begin{array}{l}-0.002 \\
(0.011)\end{array}$ & $\begin{array}{c}0.086 \\
(0.061)\end{array}$ & $\begin{array}{c}0.040 \\
(0.066)\end{array}$ & $\begin{array}{c}0.034 \\
(0.066)\end{array}$ \\
\hline Sales less than $\$ 50,000$ & $\begin{array}{l}-0.038 \\
(0.049)\end{array}$ & $\begin{array}{c}0.020 \\
(0.051)\end{array}$ & $\begin{array}{l}0.012^{* *} \\
(0.006)\end{array}$ & $\begin{array}{c}0.019 \\
(0.042)\end{array}$ & $\begin{array}{c}0.119 * * * \\
(0.043)\end{array}$ & $\begin{array}{l}-0.008 \\
(0.052)\end{array}$ \\
\hline Sales between $\$ 50,000$ - $\$ 999,999$ & $\begin{array}{c}0.024 \\
(0.051)\end{array}$ & $\begin{array}{c}0.035 \\
(0.054)\end{array}$ & $\begin{array}{c}0.019 * * * \\
(0.006)\end{array}$ & $\begin{array}{c}0.044 \\
(0.044)\end{array}$ & $\begin{array}{c}0.192^{* * *} \\
(0.046)\end{array}$ & $\begin{array}{l}-0.073 \\
(0.054)\end{array}$ \\
\hline Sales $\$ 1,000,000$ or more & $\begin{array}{l}-0.015 \\
(0.054)\end{array}$ & $\begin{array}{l}-0.038 \\
(0.056)\end{array}$ & $\begin{array}{c}0.039^{* * *} \\
(0.007)\end{array}$ & $\begin{array}{l}0.090^{* *} \\
(0.046)\end{array}$ & $\begin{array}{c}0.165^{* * *} \\
(0.049)\end{array}$ & $\begin{array}{l}-0.023 \\
(0.056)\end{array}$ \\
\hline $\begin{array}{l}\text { In-person interactions - Half } \\
\text { or less }\end{array}$ & $\begin{array}{c}0.023 \\
(0.017)\end{array}$ & $\begin{array}{c}0.086^{* * *} \\
(0.017)\end{array}$ & $\begin{array}{c}0.007^{* * *} \\
(0.002)\end{array}$ & $\begin{array}{l}-0.015 \\
(0.014)\end{array}$ & $\begin{array}{l}-0.175^{* * *} \\
(0.017)\end{array}$ & $\begin{array}{c}0.044^{* * *} \\
(0.017)\end{array}$ \\
\hline Male-owned or managed & $\begin{array}{l}-0.013 \\
(0.017)\end{array}$ & $\begin{array}{l}-0.018 \\
(0.017)\end{array}$ & $\begin{array}{l}0.005^{* *} \\
(0.002)\end{array}$ & $\begin{array}{c}0.014 \\
(0.013)\end{array}$ & $\begin{array}{c}0.016 \\
(0.016)\end{array}$ & $\begin{array}{c}-0.042^{* * *} \\
(0.016)\end{array}$ \\
\hline $\begin{array}{l}\text { Obs. } \\
R^{2}\end{array}$ & $\begin{array}{l}3,704 \\
0.053\end{array}$ & $\begin{array}{l}3,704 \\
0.035\end{array}$ & $\begin{array}{c}25,803 \\
0.009\end{array}$ & $\begin{array}{l}3,702 \\
0.038\end{array}$ & $\begin{array}{l}3,685 \\
0.059\end{array}$ & $\begin{array}{l}3,689 \\
0.013\end{array}$ \\
\hline
\end{tabular}




\section{Table 20: Reasons for Business Closure}

This table looks at how reasons for business closure vary by firm and owner characteristics. Businesses were asked "What was the main reason this business closed?". The dependent variable takes a value of one if the response is "Government or health-authority orders" (Column 1), "Financial challenges" (Column 2), or "Client or customer-related reasons" (Column 3). The omitted base groups are age - less than 1 year, industry - agriculture or mining, sales - business not operational in 2019, in-person interactions - more than half of the interactions are in-person, and gender female-owned or managed. Other variables are as defined in Table 3.

\begin{tabular}{|c|c|c|c|}
\hline & $\begin{array}{l}(1) \\
\text { Government or health } \\
\text { authority orders }\end{array}$ & $\begin{array}{c}(2) \\
\text { Financial } \\
\text { challenges }\end{array}$ & $\begin{array}{c}\text { (3) } \\
\text { Client or customer } \\
\text { related reasons } \\
\end{array}$ \\
\hline Age - Between 1 and 2 years & $\begin{array}{l}-0.041^{* *} \\
(0.021)\end{array}$ & $\begin{array}{c}0.018 \\
(0.014)\end{array}$ & $\begin{array}{l}-0.010 \\
(0.012)\end{array}$ \\
\hline Age - Between 2 and 5 years & $\begin{array}{l}-0.028 \\
(0.019)\end{array}$ & $\begin{array}{c}0.002 \\
(0.013)\end{array}$ & $\begin{array}{l}-0.012 \\
(0.011)\end{array}$ \\
\hline Age - 5 years or more & $\begin{array}{c}0.018 \\
(0.018)\end{array}$ & $\begin{array}{l}-0.030^{* * *} \\
(0.011)\end{array}$ & $\begin{array}{l}-0.011 \\
(0.010)\end{array}$ \\
\hline Construction & $\begin{array}{l}0.127^{* * *} \\
(0.047)\end{array}$ & $\begin{array}{l}-0.034 \\
(0.032)\end{array}$ & $\begin{array}{l}0.059^{* *} \\
(0.025)\end{array}$ \\
\hline Hotels, cafes, and restaurants & $\begin{array}{l}0.197^{* * *} \\
(0.043)\end{array}$ & $\begin{array}{l}-0.040 \\
(0.029)\end{array}$ & $\begin{array}{c}0.009 \\
(0.020)\end{array}$ \\
\hline Information and communication & $\begin{array}{l}-0.013 \\
(0.047)\end{array}$ & $\begin{array}{c}0.018 \\
(0.034)\end{array}$ & $\begin{array}{l}0.103^{* * *} \\
(0.027)\end{array}$ \\
\hline Manufacturing & $\begin{array}{c}0.088 \\
(0.058)\end{array}$ & $\begin{array}{l}-0.015 \\
(0.039)\end{array}$ & $\begin{array}{c}0.046 \\
(0.031)\end{array}$ \\
\hline Other & $\begin{array}{l}0.215^{* * *} \\
(0.041)\end{array}$ & $\begin{array}{l}-0.060^{* *} \\
(0.028)\end{array}$ & $\begin{array}{c}0.004 \\
(0.019)\end{array}$ \\
\hline Retail and wholesale trade & $\begin{array}{c}0.138^{* * *} \\
(0.042)\end{array}$ & $\begin{array}{l}-0.004 \\
(0.029)\end{array}$ & $\begin{array}{c}0.007 \\
(0.019)\end{array}$ \\
\hline Services & $\begin{array}{c}0.245^{* * *} \\
(0.040)\end{array}$ & $\begin{array}{l}-0.064^{* *} \\
(0.028)\end{array}$ & $\begin{array}{c}0.027 \\
(0.019)\end{array}$ \\
\hline Transportation and logistics & $\begin{array}{c}0.026 \\
(0.052)\end{array}$ & $\begin{array}{l}-0.021 \\
(0.035)\end{array}$ & $\begin{array}{l}0.060^{* *} \\
(0.028)\end{array}$ \\
\hline Sales less than $\$ 50,000$ & $\begin{array}{l}0.080^{* * *} \\
(0.025)\end{array}$ & $\begin{array}{l}-0.031^{*} \\
(0.018)\end{array}$ & $\begin{array}{l}0.049^{* * *} \\
(0.012)\end{array}$ \\
\hline Sales between $\$ 50,000$ - $\$ 999,999$ & $\begin{array}{c}0.208^{* * *} \\
(0.026)\end{array}$ & $\begin{array}{l}-0.040^{* *} \\
(0.018)\end{array}$ & $\begin{array}{l}0.021^{*} \\
(0.013)\end{array}$ \\
\hline Sales $\$ 1,000,000$ or more & $\begin{array}{l}0.194^{* * *} \\
(0.029)\end{array}$ & $\begin{array}{l}-0.052^{* * *} \\
(0.020)\end{array}$ & $\begin{array}{l}0.025^{*} \\
(0.014)\end{array}$ \\
\hline $\begin{array}{l}\text { In-person interactions - Half } \\
\text { or less }\end{array}$ & $\begin{array}{l}-0.183^{* * *} \\
(0.011)\end{array}$ & $\begin{array}{l}0.053^{* * *} \\
(0.006)\end{array}$ & $\begin{array}{c}0.035^{* * *} \\
(0.006)\end{array}$ \\
\hline Male-owned or managed & $\begin{array}{l}-0.013 \\
(0.010) \\
\end{array}$ & $\begin{array}{l}0.012^{* *} \\
(0.006) \\
\end{array}$ & $\begin{array}{l}0.010^{*} \\
(0.006) \\
\end{array}$ \\
\hline $\begin{array}{l}\text { Obs. } \\
R^{2}\end{array}$ & $\begin{array}{l}9,144 \\
0.101\end{array}$ & $\begin{array}{l}9,144 \\
0.032\end{array}$ & $\begin{array}{l}9,144 \\
0.019\end{array}$ \\
\hline
\end{tabular}




\section{Table 21: Business Re-opening}

This table looks at how actions for business re-opening vary by firm and owner characteristics. Businesses were asked 'What would be the most important action for this business to re-open in the future?". The dependent variable takes a value of one if the response was "Government allowing business operations" (Column 1), or "Securing funds" (Column 2). In Column 3, the dependent variable takes a value of one if the business responds "Totally different products or services" or "Some different products or services in addition to the products or services offered before" to "Compared to before this business closed, what type of products or services will be offered when it reopens?". The omitted base groups are age - less than 1 year, industry - agriculture or mining, sales - business not operational in 2019, in-person interactions - more than half of the interactions are in-person, and gender - female-owned or managed. Other variables are as defined in Table 3.

\begin{tabular}{|c|c|c|c|}
\hline & $\begin{array}{c}\text { (1) } \\
\text { Government allowing } \\
\text { business operations }\end{array}$ & $\begin{array}{c}(2) \\
\text { Securing } \\
\text { funds }\end{array}$ & $\begin{array}{c}\text { (3) } \\
\text { Provide new } \\
\text { products and services }\end{array}$ \\
\hline Age - Between 1 and 2 years & $\begin{array}{l}-0.016 \\
(0.022)\end{array}$ & $\begin{array}{l}-0.033 \\
(0.021)\end{array}$ & $\begin{array}{c}0.031 \\
(0.021)\end{array}$ \\
\hline Age - Between 2 and 5 years & $\begin{array}{l}-0.001 \\
(0.021)\end{array}$ & $\begin{array}{l}-0.054^{* * *} \\
(0.019)\end{array}$ & $\begin{array}{c}0.018 \\
(0.019)\end{array}$ \\
\hline Age -5 years or more & $\begin{array}{l}0.040^{* *} \\
(0.019)\end{array}$ & $\begin{array}{l}-0.091^{* * *} \\
(0.017)\end{array}$ & $\begin{array}{l}-0.029 \\
(0.018)\end{array}$ \\
\hline Construction & $\begin{array}{l}0.085^{*} \\
(0.049)\end{array}$ & $\begin{array}{c}0.037 \\
(0.044)\end{array}$ & $\begin{array}{l}-0.206^{* * *} \\
(0.044)\end{array}$ \\
\hline Hotels, cafes, and restaurants & $\begin{array}{l}0.101^{* *} \\
(0.045)\end{array}$ & $\begin{array}{l}-0.008 \\
(0.040)\end{array}$ & $\begin{array}{l}-0.051 \\
(0.043)\end{array}$ \\
\hline Information and communication & $\begin{array}{l}-0.008 \\
(0.049)\end{array}$ & $\begin{array}{c}0.036 \\
(0.045)\end{array}$ & $\begin{array}{c}0.028 \\
(0.048)\end{array}$ \\
\hline Manufacturing & $\begin{array}{c}0.002 \\
(0.061)\end{array}$ & $\begin{array}{c}0.003 \\
(0.054)\end{array}$ & $\begin{array}{l}-0.069 \\
(0.058)\end{array}$ \\
\hline Other & $\begin{array}{l}0.133^{* * *} \\
(0.042)\end{array}$ & $\begin{array}{l}-0.083^{* *} \\
(0.038)\end{array}$ & $\begin{array}{l}-0.066 \\
(0.041)\end{array}$ \\
\hline Retail and wholesale trade & $\begin{array}{l}0.095^{* *} \\
(0.043)\end{array}$ & $\begin{array}{l}-0.013 \\
(0.039)\end{array}$ & $\begin{array}{l}-0.055 \\
(0.042)\end{array}$ \\
\hline Services & $\begin{array}{c}0.183^{* * *} \\
(0.042)\end{array}$ & $\begin{array}{c}-0.065^{*} \\
(0.038)\end{array}$ & $\begin{array}{l}-0.086^{* *} \\
(0.041)\end{array}$ \\
\hline Transportation and logistics & $\begin{array}{c}0.009 \\
(0.053)\end{array}$ & $\begin{array}{c}0.020 \\
(0.049)\end{array}$ & $\begin{array}{l}-0.194^{* * *} \\
(0.047)\end{array}$ \\
\hline Sales less than $\$ 50,000$ & $\begin{array}{l}0.069^{* *} \\
(0.027)\end{array}$ & $\begin{array}{c}0.007 \\
(0.025)\end{array}$ & $\begin{array}{l}-0.033 \\
(0.026)\end{array}$ \\
\hline Sales between $\$ 50,000$ - $\$ 999,999$ & $\begin{array}{c}0.127^{* * *} \\
(0.028)\end{array}$ & $\begin{array}{c}0.042 \\
(0.027)\end{array}$ & $\begin{array}{l}-0.020 \\
(0.027)\end{array}$ \\
\hline Sales $\$ 1,000,000$ or more & $\begin{array}{c}0.194^{* * *} \\
(0.031)\end{array}$ & $\begin{array}{l}-0.058^{* *} \\
(0.028)\end{array}$ & $\begin{array}{l}-0.038 \\
(0.030)\end{array}$ \\
\hline $\begin{array}{l}\text { In-person interactions - Half } \\
\text { or less }\end{array}$ & $\begin{array}{l}-0.130^{* * *} \\
(0.011)\end{array}$ & $\begin{array}{l}0.042^{* * *} \\
(0.010)\end{array}$ & $\begin{array}{l}0.056^{* * *} \\
(0.010)\end{array}$ \\
\hline Male-owned or managed & $\begin{array}{l}-0.015 \\
(0.011) \\
\end{array}$ & $\begin{array}{c}0.033^{* * *} \\
(0.009)\end{array}$ & $\begin{array}{c}0.011 \\
(0.010) \\
\end{array}$ \\
\hline $\begin{array}{l}\text { Obs. } \\
R^{2}\end{array}$ & $\begin{array}{l}8,716 \\
0.048\end{array}$ & $\begin{array}{l}8,716 \\
0.026\end{array}$ & $\begin{array}{l}8,621 \\
0.016\end{array}$ \\
\hline
\end{tabular}


Table 22: Business Challenges and Support Needs

This table looks at how business challenges and support needs vary by firm and owner characteristics. Businesses were asked "In which of the following is this business facing the most challenges and would need support with to survive the current situation?". The dependent variable takes a value of one if the response was "Access to capital or funding" (Column 1), "Employees/Workers" (Column 2), "Government intervention or regulation changes" (Column 3), "Support taking care of household members" (Column 4), "Online tools and resources" (Column 5) or "Information resources" (Column 6). The omitted base groups are age - less than 1 year, industry - agriculture or mining, sales - business not operational in 2019, in-person interactions - more than half of the interactions are in-person, and gender - female-owned or managed. Other variables are as defined in Table 3.

\begin{tabular}{|c|c|c|c|c|c|c|}
\hline & $\begin{array}{c}(1) \\
\text { Capital }\end{array}$ & $\begin{array}{c}(2) \\
\text { Employees }\end{array}$ & $\begin{array}{c}(3) \\
\text { Government } \\
\text { regulation }\end{array}$ & $\begin{array}{c}(4) \\
\text { Care of } \\
\text { HH member }\end{array}$ & $\begin{array}{l}(5) \\
\text { Online } \\
\text { tools }\end{array}$ & $\begin{array}{c}(6) \\
\text { Information }\end{array}$ \\
\hline Age - Between 1 and 2 years & $\begin{array}{c}0.018 \\
(0.020)\end{array}$ & $\begin{array}{c}-0.020^{*} \\
(0.011)\end{array}$ & $\begin{array}{l}-0.004 \\
(0.012)\end{array}$ & $\begin{array}{l}-0.008 \\
(0.014)\end{array}$ & $\begin{array}{l}0.031^{* *} \\
(0.013)\end{array}$ & $\begin{array}{l}-0.008 \\
(0.008)\end{array}$ \\
\hline Age - Between 2 and 5 years & $\begin{array}{c}0.025 \\
(0.019)\end{array}$ & $\begin{array}{c}-0.021^{* *} \\
(0.010)\end{array}$ & $\begin{array}{l}-0.003 \\
(0.012)\end{array}$ & $\begin{array}{l}-0.012 \\
(0.013)\end{array}$ & $\begin{array}{c}0.017 \\
(0.012)\end{array}$ & $\begin{array}{l}-0.011 \\
(0.008)\end{array}$ \\
\hline Age - 5 years or more & $\begin{array}{c}-0.043^{* *} \\
(0.018)\end{array}$ & $\begin{array}{c}0.015 \\
(0.010)\end{array}$ & $\begin{array}{c}0.014 \\
(0.011)\end{array}$ & $\begin{array}{l}-0.020 \\
(0.013)\end{array}$ & $\begin{array}{c}0.016 \\
(0.011)\end{array}$ & $\begin{array}{l}-0.005 \\
(0.007)\end{array}$ \\
\hline Construction & $\begin{array}{c}0.082^{* * *} \\
(0.027)\end{array}$ & $\begin{array}{c}0.028 \\
(0.022)\end{array}$ & $\begin{array}{c}-0.038^{*} \\
(0.021)\end{array}$ & $\begin{array}{l}-0.022 \\
(0.018)\end{array}$ & $\begin{array}{l}-0.021 \\
(0.014)\end{array}$ & $\begin{array}{l}-0.008 \\
(0.012)\end{array}$ \\
\hline Hotels, cafes, and restaurants & $\begin{array}{c}0.131^{* * *} \\
(0.027)\end{array}$ & $\begin{array}{c}0.004 \\
(0.021)\end{array}$ & $\begin{array}{c}0.028 \\
(0.022)\end{array}$ & $\begin{array}{c}-0.049^{* * *} \\
(0.017)\end{array}$ & $\begin{array}{c}-0.026^{*} \\
(0.013)\end{array}$ & $\begin{array}{c}-0.023^{* *} \\
(0.011)\end{array}$ \\
\hline Information and communication & $\begin{array}{c}0.119^{* * *} \\
(0.026)\end{array}$ & $\begin{array}{l}-0.018 \\
(0.020)\end{array}$ & $\begin{array}{c}-0.050^{* *} \\
(0.020)\end{array}$ & $\begin{array}{c}0.005 \\
(0.018)\end{array}$ & $\begin{array}{c}0.013 \\
(0.015)\end{array}$ & $\begin{array}{c}0.003 \\
(0.012)\end{array}$ \\
\hline Manufacturing & $\begin{array}{l}0.057^{*} \\
(0.030)\end{array}$ & $\begin{array}{c}0.032 \\
(0.025)\end{array}$ & $\begin{array}{l}-0.026 \\
(0.024)\end{array}$ & $\begin{array}{l}-0.009 \\
(0.021)\end{array}$ & $\begin{array}{l}-0.013 \\
(0.016)\end{array}$ & $\begin{array}{l}-0.005 \\
(0.013)\end{array}$ \\
\hline Other & $\begin{array}{c}0.093^{* * *} \\
(0.024)\end{array}$ & $\begin{array}{c}-0.061^{* * *} \\
(0.018)\end{array}$ & $\begin{array}{l}-0.014 \\
(0.019)\end{array}$ & $\begin{array}{l}-0.020 \\
(0.016)\end{array}$ & $\begin{array}{c}0.013 \\
(0.013)\end{array}$ & $\begin{array}{l}-0.014 \\
(0.011)\end{array}$ \\
\hline Retail and wholesale trade & $\begin{array}{c}0.096^{* * *} \\
(0.024)\end{array}$ & $\begin{array}{l}-0.016 \\
(0.018)\end{array}$ & $\begin{array}{c}-0.055^{* * *} \\
(0.018)\end{array}$ & $\begin{array}{l}-0.002 \\
(0.017)\end{array}$ & $\begin{array}{c}0.039^{* * *} \\
(0.014)\end{array}$ & $\begin{array}{c}-0.019^{*} \\
(0.011)\end{array}$ \\
\hline Services & $\begin{array}{c}0.114^{* * *} \\
(0.023)\end{array}$ & $\begin{array}{c}-0.037^{* *} \\
(0.018)\end{array}$ & $\begin{array}{l}-0.023 \\
(0.018)\end{array}$ & $\begin{array}{c}0.002 \\
(0.016)\end{array}$ & $\begin{array}{c}0.006 \\
(0.013)\end{array}$ & $\begin{array}{l}-0.012 \\
(0.011)\end{array}$ \\
\hline Transportation and logistics & $\begin{array}{c}0.044 \\
(0.031)\end{array}$ & $\begin{array}{l}-0.003 \\
(0.025)\end{array}$ & $\begin{array}{l}-0.000 \\
(0.025)\end{array}$ & $\begin{array}{l}-0.011 \\
(0.020)\end{array}$ & $\begin{array}{l}-0.017 \\
(0.015)\end{array}$ & $\begin{array}{c}0.008 \\
(0.014)\end{array}$ \\
\hline Sales less than $\$ 50,000$ & $\begin{array}{c}0.008 \\
(0.026)\end{array}$ & $\begin{array}{c}0.006 \\
(0.012)\end{array}$ & $\begin{array}{l}-0.011 \\
(0.016)\end{array}$ & $\begin{array}{c}0.014 \\
(0.019)\end{array}$ & $\begin{array}{l}-0.013 \\
(0.018)\end{array}$ & $\begin{array}{l}-0.000 \\
(0.011)\end{array}$ \\
\hline Sales between $\$ 50,000$ - $\$ 999,999$ & $\begin{array}{c}0.094^{* * *} \\
(0.027)\end{array}$ & $\begin{array}{c}0.066^{* * *} \\
(0.014)\end{array}$ & $\begin{array}{c}0.014 \\
(0.017)\end{array}$ & $\begin{array}{c}-0.042^{* *} \\
(0.019)\end{array}$ & $\begin{array}{c}-0.076^{* * *} \\
(0.018)\end{array}$ & $\begin{array}{l}-0.018 \\
(0.012)\end{array}$ \\
\hline Sales $\$ 1,000,000$ or more & $\begin{array}{c}-0.084^{* * *} \\
(0.028)\end{array}$ & $\begin{array}{c}0.198^{* * *} \\
(0.015)\end{array}$ & $\begin{array}{c}0.050^{* * *} \\
(0.018)\end{array}$ & $\begin{array}{l}-0.023 \\
(0.020)\end{array}$ & $\begin{array}{c}-0.083^{* * *} \\
(0.018)\end{array}$ & $\begin{array}{c}-0.020^{*} \\
(0.012)\end{array}$ \\
\hline $\begin{array}{l}\text { In-person interactions - Half } \\
\text { or less }\end{array}$ & $\begin{array}{c}0.011 \\
(0.008)\end{array}$ & $\begin{array}{l}-0.040^{* * *} \\
(0.006)\end{array}$ & $\begin{array}{l}-0.032^{* * *} \\
(0.006)\end{array}$ & $\begin{array}{c}0.025^{* * *} \\
(0.005)\end{array}$ & $\begin{array}{c}0.026^{* * *} \\
(0.004)\end{array}$ & $\begin{array}{l}-0.000 \\
(0.003)\end{array}$ \\
\hline Male-owned or managed & $\begin{array}{c}0.033^{* * *} \\
(0.008)\end{array}$ & $\begin{array}{l}-0.001 \\
(0.006)\end{array}$ & $\begin{array}{c}0.026^{* * *} \\
(0.006)\end{array}$ & $\begin{array}{l}-0.044^{* * *} \\
(0.005)\end{array}$ & $\begin{array}{l}-0.023^{* * *} \\
(0.004)\end{array}$ & $\begin{array}{c}0.000 \\
(0.003)\end{array}$ \\
\hline $\begin{array}{l}\text { Obs. } \\
R^{2}\end{array}$ & $\begin{array}{c}15,567 \\
0.031\end{array}$ & $\begin{array}{c}15,567 \\
0.072\end{array}$ & $\begin{array}{c}15,567 \\
0.018\end{array}$ & $\begin{array}{c}15,567 \\
0.020\end{array}$ & $\begin{array}{c}15,567 \\
0.030\end{array}$ & $\begin{array}{c}15,567 \\
0.004\end{array}$ \\
\hline
\end{tabular}




\section{Table 23: Business Support Policies}

This table looks at how policies to support businesses vary by firm and owner characteristics. Businesses were asked "What would be the three most needed policies to support this business over the COVID-19 crisis?". The dependent variable takes a value of one if the response was "Salary subsidies" (Column 1), "Access to loan and credit guarantees" (Column 2), or "Tax deferral" (Column $3)$. The omitted base groups are age - less than 1 year, industry - agriculture or mining, sales business not operational in 2019, in-person interactions - more than half of the interactions are in-person, and gender - female-owned or managed. Other variables are as defined in Table 3.

\begin{tabular}{|c|c|c|c|}
\hline & $\begin{array}{c}\text { (1) } \\
\text { Salary subsidies }\end{array}$ & $\begin{array}{l}\text { (2) } \\
\text { Access to loan/ } \\
\text { credit guarantees }\end{array}$ & $\begin{array}{c}(3) \\
\text { Tax deferral }\end{array}$ \\
\hline Age - Between 1 and 2 years & $\begin{array}{l}-0.010 \\
(0.018)\end{array}$ & $\begin{array}{l}-0.007 \\
(0.020)\end{array}$ & $\begin{array}{l}-0.018 \\
(0.018)\end{array}$ \\
\hline Age - Between 2 and 5 years & $\begin{array}{l}-0.006 \\
(0.017)\end{array}$ & $\begin{array}{c}0.015 \\
(0.018)\end{array}$ & $\begin{array}{c}-0.009 \\
(0.017)\end{array}$ \\
\hline Age - 5 years or more & $\begin{array}{c}0.021 \\
(0.016)\end{array}$ & $\begin{array}{c}-0.062^{* * *} \\
(0.017)\end{array}$ & $\begin{array}{l}-0.005 \\
(0.016)\end{array}$ \\
\hline Construction & $\begin{array}{c}0.084^{* * *} \\
(0.026)\end{array}$ & $\begin{array}{c}0.070^{* * *} \\
(0.026)\end{array}$ & $\begin{array}{c}0.080^{* * *} \\
(0.026)\end{array}$ \\
\hline Hotels, cafes, and restaurants & $\begin{array}{c}0.131^{* * *} \\
(0.026)\end{array}$ & $\begin{array}{c}0.090^{* * * *} \\
(0.026)\end{array}$ & $\begin{array}{l}0.053^{* *} \\
(0.025)\end{array}$ \\
\hline Information and communication & $\begin{array}{c}0.145^{* * *} \\
(0.025)\end{array}$ & $\begin{array}{l}0.049^{*} \\
(0.025)\end{array}$ & $\begin{array}{c}0.035 \\
(0.024)\end{array}$ \\
\hline Manufacturing & $\begin{array}{c}0.089^{* * *} \\
(0.029)\end{array}$ & $\begin{array}{c}0.015 \\
(0.030)\end{array}$ & $\begin{array}{c}0.023 \\
(0.029)\end{array}$ \\
\hline Other & $\begin{array}{c}0.115^{* * *} \\
(0.022)\end{array}$ & $\begin{array}{l}0.045^{* *} \\
(0.023)\end{array}$ & $\begin{array}{l}-0.012 \\
(0.022)\end{array}$ \\
\hline Retail and wholesale trade & $\begin{array}{c}0.069^{* * *} \\
(0.022)\end{array}$ & $\begin{array}{c}0.059^{* * * *} \\
(0.023)\end{array}$ & $\begin{array}{c}0.029 \\
(0.022)\end{array}$ \\
\hline Services & $\begin{array}{c}0.125^{* * *} \\
(0.021)\end{array}$ & $\begin{array}{c}0.072^{* * *} \\
(0.022)\end{array}$ & $\begin{array}{c}0.027 \\
(0.021)\end{array}$ \\
\hline Transportation and logistics & $\begin{array}{c}0.078^{* * *} \\
(0.030)\end{array}$ & $\begin{array}{l}0.057^{*} \\
(0.031)\end{array}$ & $\begin{array}{l}0.075^{* *} \\
(0.030)\end{array}$ \\
\hline Sales less than $\$ 50,000$ & $\begin{array}{c}0.032 \\
(0.022)\end{array}$ & $\begin{array}{c}0.007 \\
(0.025)\end{array}$ & $\begin{array}{c}0.016 \\
(0.023)\end{array}$ \\
\hline Sales between $\$ 50,000$ - $\$ 999,999$ & $\begin{array}{l}0.176^{* * *} \\
(0.023)\end{array}$ & $\begin{array}{l}0.125^{* * *} \\
(0.026)\end{array}$ & $\begin{array}{l}0.102^{* * *} \\
(0.024)\end{array}$ \\
\hline Sales $\$ 1,000,000$ or more & $\begin{array}{l}0.246^{* * *} \\
(0.024)\end{array}$ & $\begin{array}{c}0.037 \\
(0.027)\end{array}$ & $\begin{array}{l}0.074^{* * *} \\
(0.025)\end{array}$ \\
\hline $\begin{array}{l}\text { In-person interactions - Half } \\
\text { or less }\end{array}$ & $\begin{array}{c}-0.032^{* * *} \\
(0.008)\end{array}$ & $\begin{array}{l}-0.005 \\
(0.008)\end{array}$ & $\begin{array}{c}0.003 \\
(0.008)\end{array}$ \\
\hline Male-owned or managed & $\begin{array}{c}-0.025^{* * *} \\
(0.008)\end{array}$ & $\begin{array}{c}0.048^{* * *} \\
(0.008)\end{array}$ & $\begin{array}{c}0.040^{* * *} \\
(0.007)\end{array}$ \\
\hline $\begin{array}{l}\text { Obs. } \\
R^{2}\end{array}$ & $\begin{array}{c}16,615 \\
0.043\end{array}$ & $\begin{array}{c}16,615 \\
0.019\end{array}$ & $\begin{array}{c}16,615 \\
0.014\end{array}$ \\
\hline
\end{tabular}




\section{Table 24: Employee Perspective: Business and Household Struggles}

This table looks at how the difficulty in conducting business due to household distractions, and how the difficulty in doing household work due to job distractions, varies by individual characteristics. Households were asked "How much have your business responsibilities affected your ability to take care of your household during the coronavirus (COVID-19) pandemic?" and "How much have your household responsibilities affected your ability to focus on this business during the coronavirus (COVID19) pandemic?". The dependent variable takes a value of one if the response was either "A lot" or "A great deal", and zero otherwise. The regressors are gender, age, area, education, firm sector, remote-work ability and having to take care of school-age children due to school closures. The coefficients for education and sector are omitted from the table to increase legibility. The omitted default values are female, older than 66, rural, remote work - not at all and children - no, respectively.

\begin{tabular}{|c|c|c|}
\hline & $\begin{array}{c}(1) \\
\text { Difficulty in } \\
\text { conducting business }\end{array}$ & $\begin{array}{c}(2) \\
\text { Difficulty in } \\
\text { caring for household }\end{array}$ \\
\hline Male & $\begin{array}{l}-0.047^{* * *} \\
(0.010)\end{array}$ & $\begin{array}{l}-0.053^{* * *} \\
(0.010)\end{array}$ \\
\hline Age -56 to 65 & $\begin{array}{c}0.011 \\
(0.027)\end{array}$ & $\begin{array}{c}0.023 \\
(0.023)\end{array}$ \\
\hline Age -46 to 55 & $\begin{array}{c}0.009 \\
(0.027)\end{array}$ & $\begin{array}{l}0.039^{*} \\
(0.023)\end{array}$ \\
\hline Age -36 to 45 & $\begin{array}{l}0.066^{* *} \\
(0.027)\end{array}$ & $\begin{array}{l}0.081^{* * *} \\
(0.023)\end{array}$ \\
\hline Age -26 to 35 & $\begin{array}{l}0.083^{* * *} \\
(0.027)\end{array}$ & $\begin{array}{l}0.096^{* * *} \\
(0.022)\end{array}$ \\
\hline Age -18 to 25 & $\begin{array}{l}0.088^{* * *} \\
(0.029)\end{array}$ & $\begin{array}{l}0.144^{* * *} \\
(0.026)\end{array}$ \\
\hline Age - Younger than 18 & $\begin{array}{c}0.016 \\
(0.084)\end{array}$ & $\begin{array}{c}0.125 \\
(0.081)\end{array}$ \\
\hline Suburban & $\begin{array}{c}0.001 \\
(0.012)\end{array}$ & $\begin{array}{l}-0.007 \\
(0.011)\end{array}$ \\
\hline Urban & $\begin{array}{l}0.034^{* *} \\
(0.014)\end{array}$ & $\begin{array}{l}0.023^{*} \\
(0.013)\end{array}$ \\
\hline $\begin{array}{l}\text { Remote work - Yes, some of the } \\
\text { time }\end{array}$ & $\begin{array}{c}0.065^{* * *} \\
(0.014)\end{array}$ & $\begin{array}{l}-0.005 \\
(0.013)\end{array}$ \\
\hline $\begin{array}{l}\text { Remote work - Yes, all of the } \\
\text { time }\end{array}$ & $\begin{array}{l}-0.021^{*} \\
(0.012)\end{array}$ & $\begin{array}{l}-0.091^{* * *} \\
(0.011)\end{array}$ \\
\hline $\begin{array}{l}\text { Children - Yes, but I am not the } \\
\text { primary caregiver }\end{array}$ & $\begin{array}{l}0.118^{* * *} \\
(0.018)\end{array}$ & $\begin{array}{l}0.077^{* * *} \\
(0.016)\end{array}$ \\
\hline $\begin{array}{l}\text { Children - Yes, and I am the } \\
\text { primary caregiver }\end{array}$ & $\begin{array}{l}0.256^{* * *} \\
(0.013)\end{array}$ & $\begin{array}{l}0.155^{* * *} \\
(0.012)\end{array}$ \\
\hline $\begin{array}{l}\text { Obs. } \\
R^{2}\end{array}$ & $\begin{array}{l}7,182 \\
0.101\end{array}$ & $\begin{array}{l}7,184 \\
0.065\end{array}$ \\
\hline
\end{tabular}




\title{
The EFFECTS OF COVID-19 ON U.S. SMALl BusinesSES: EVIDENCE FROM OWNers, MANAgers, AND EMPloyeEs*
}

\author{
APPENDiX \\ Georgij Alekseev ${ }^{\dagger}$ SafaA Amer ${ }^{\ddagger}$ Manasa Gopal ${ }^{\S}$ Theresa Kuchler ${ }^{\llbracket}$ \\ JW SCHNEIDER $\|$ JOHANNES STROEBEL ${ }^{* *}$ NILS WERNERFELT ${ }^{\dagger \dagger}$
}

September 2020

\section{Contents}

$\begin{array}{llc}\text { A.I } \quad \text { Business Operations } & 1\end{array}$

$\begin{array}{ll}\text { A.II } \quad \text { Business Survival Strategy } & 1\end{array}$

$\begin{array}{lll}\text { A.III } & \text { Closed Businesses } & 1\end{array}$

$\begin{array}{llr}\text { A.IV Employees } & 2\end{array}$

$\begin{array}{llc}\text { A.V Figures } & \text { A.3 }\end{array}$

$\begin{array}{lll}\text { A.VI } & \text { Figures - Small Business Employees Only } & \text { A.13 }\end{array}$

$\begin{array}{llr}\text { A.VII Tables } & \text { A.22 }\end{array}$

*Amer, Schneider, and Wernerfelt are employees at Facebook. Kuchler and Stroebel have a research consulting relationship with Facebook.

†NYU Stern. Email: galeksee@stern.nyu.edu.

${ }_{\ddagger}^{\ddagger}$ Facebook. Email: safy@fb.com.

§Scheller College of Business, Georgia Tech. Email: manasa.gopal@scheller.gatech.edu.

`NYU Stern. NBER, CEPR. Email: theresa.kuchler@nyu.edu.

\|Facebook. Email: jdub@fb.com.

**NYU Stern. NBER, CEPR. Email: johannes.stroebel@nyu.edu.

††Facebook. Email: nilsw@fb.com. 


\section{A.I BUSINESS OPERATIONS}

Businesses with a drop in sales, on average, have seen sales falling by more than $50 \%$, and $11.6 \%$ of firms have seen a drop of over $90 \%$. On the other extreme, $17.5 \%$ of firms with increased sales saw their sales more than double, while $37.1 \%$ of the firms saw growth between $10-30 \%$.

On average, larger businesses (employment) have seen more sales growth (Figure A.3, Panel A), as have businesses in agriculture or mining (Panel B), and younger firms (Panel C). ${ }^{1}$ Panel D suggests a U-shaped relationship between sales and change in sales during the pandemic $34.2 \%$ of firms with sales $\leq \$ 5,000$ in 2019 saw reduced sales, compared to $68.7 \%$ of firms with sales between $\$ 100,000-\$ 250,000$ and $52.8 \%$ of firms with sales $\geq \$ 3$ million. Panel $E$ shows that $61.1 \%$ of majority-female businesses have had lower sales, compared to $54.3 \%$ of majority-male businesses. Finally, we show that firms with fewer in-person interactions have seen a drop in sales less often $-59.9 \%$ of firms with all their interactions in-person compared to $43.6 \%$ of firms with none of their interactions in-person (Panel F).

Table A.1 presents these correlations between firm characteristics and sales in a regression table. The results corroborate the previous observations and all coefficients are significant.

\section{A.II Business SuRViVAl StRATEgy}

We look at heterogeneities in the share of revenue coming from online sales against business strategies. Many firms that got all their revenues from online sales were the ones that got their information from social media $(33.3 \%)$, online groups $(36.0 \%)$, or news on the internet $(32.2 \%)-$ in comparison to firms that relied on radio (26.1\%) or print (26.7\%, Figure A.4, Panel A). Similarly, firms that adopted online tools were more likely to get their revenues from online sales - firms that often get all their revenues from online sales had a phone app (33.1\%), digital ordering tools $(34.6 \%)$, digital payment tools (34.6\%), or a website (33.4\%, Panel B). Finally, the share of online revenues also varied with client accommodations. Firms providing online services $(30.2 \%)$ or free cancellation (30.7\%) often made all their sales online - unlike firms offering curbside pickup, of which $15.4 \%$ made all their sales online.

\section{A.III Closed Businesses}

Figure A.5 Panel A shows that the closure reason also affects the actions businesses think are important for re-opening. Firms that closed due to government orders thought government permission would be the most important requirement with $69.5 \%$ mentioning it as the top reason. For businesses facing financial challenges, $54.9 \%$ stated they need to secure funds to re-open.

Plans for future product offerings differed by closure reason. Panel B of Figure A.5 shows that firms facing financial challenges were more likely to plan new products (37.0\%), whereas firms that were closed due to government orders were less likely to consider altering their offering.

\footnotetext{
${ }^{1}$ Excluding firms that are younger than one year, since they lack comparability.
} 


\section{A.IV EMPlOyeES}

Employees $\mathcal{E}$ Household Responsibilities. We asked workers about the amount of time spent on domestic or household care activities (Figure A.10 Panel A). The modal answer was between 1-2 hours $(25.8 \%)$, though $19.7 \%$ spent more than 5 hours per day. There were heterogeneities in the responses $-30.3 \%$ of primary caregivers were spending 5 or more hours per day on household activities, compared to $11.0 \%$ of respondents that did not have to take care of children affected by school closures (Panel B). We looked at the heterogeneities in a multivariate regression controlling for gender, age, sector, education, area, remote-work and having to take care of children due to school closures (Table A.3). Men aged 46-65 spent the least amount of time on household duties, whereas primary caregivers and respondents sometimes able to work remotely spent the most. We included an interaction term between remote-work and gender, which turned out to be insignificant.

Employee Income Sources, Benefits and Concerns. The most common income sources among employed respondents were their job income (75.3\%), their partner's income $(30.1 \%)$, personal savings (19.6\%), and social security benefits (12.4\%, Figure A.11, Panel A). Income sources varied by household characteristics (Panel B and C) - women and primary caregivers affected by school closures relied more often on their partner's income.

Benefits received by employees during the crisis included health insurance $(54.1 \%)$, paid time off $(38.0 \%)$, paid sick leave (33.0\%), and unemployment benefits (20.0\%, Figure A.12, Panel A). Only $11.8 \%$ of workers stated they had applied for any kind of government/NGO assistance in response to the pandemic (Panel B). Respondents that took care of children due to school closures applied more often for assistance - primary and non-primary caregivers alike.

Among those who had not applied for government/NGO assistance, 24.6\% did not satisfy the eligibility criteria and $11.9 \%$ did not know the application procedures. Among those who applied, $56.1 \%$ received unemployment benefits, though $24.9 \%$ received nothing (Panel E).

Finally, we asked respondents about their top three concerns during the pandemic (Figure A.13, Panel A). The most common concerns were having enough money to sustain the household (48.7\%), having enough food and basic supplies (44.7\%), and losing their current job (37.7\%). Respondents that had to take care of children were substantially more worried about having enough food, supplies, and money for their family than they were about losing their current job (Panel B). 


\section{A.V FIGURES}

\section{Figure A.1: Screenshots of Survey Invitation and First Question}

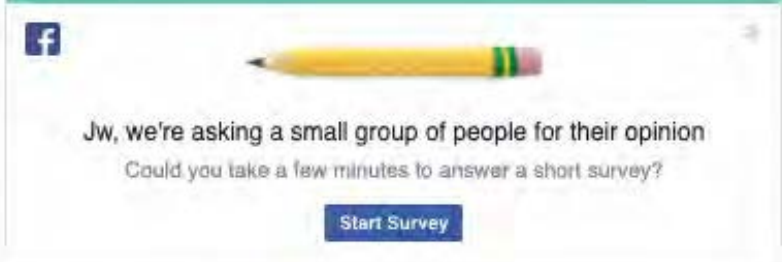

(A) Invitation to take the survey, as it would appear to one of the coauthors

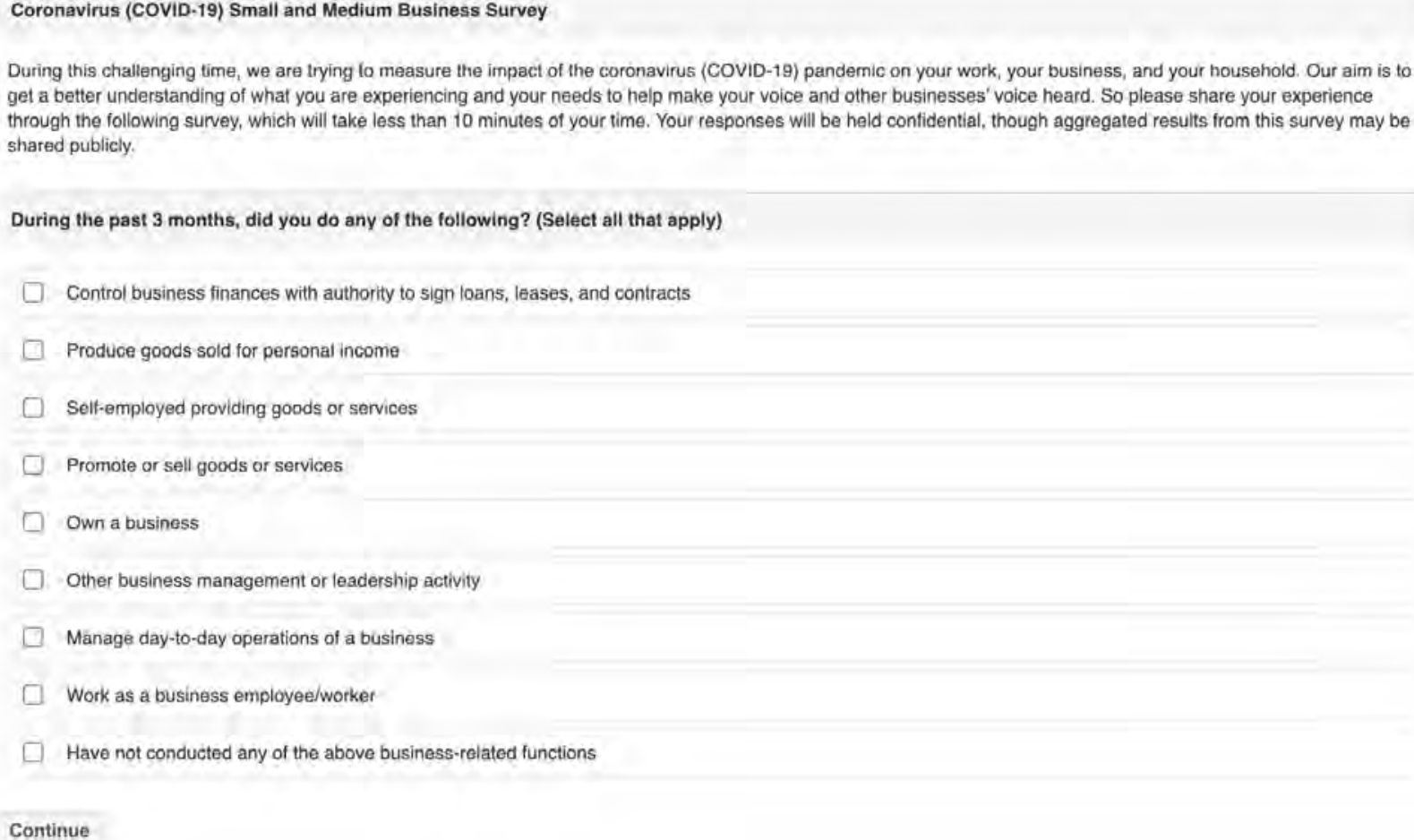

(B) First question, shown after accepting the survey invitation 
Figure A.2: Business Employees - Work from Home Crosstabs

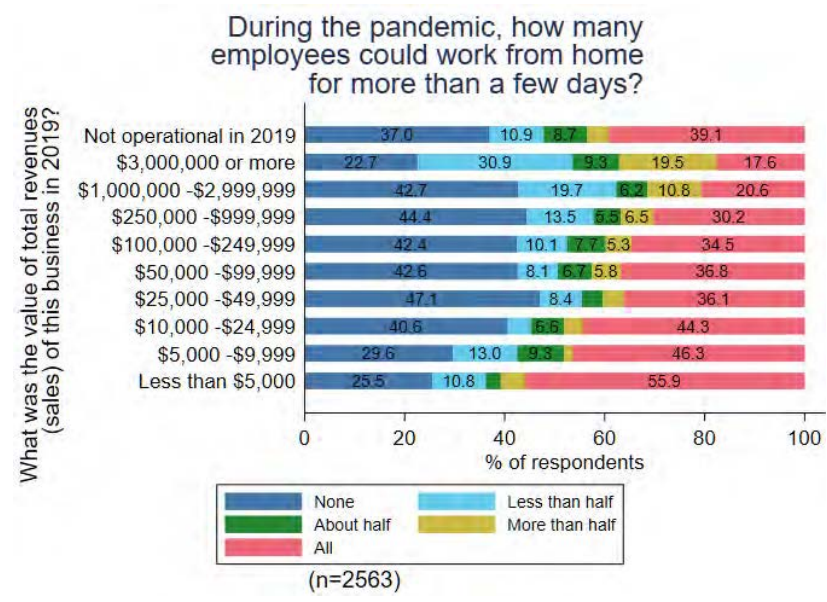

(A) Work From Home, by Sales

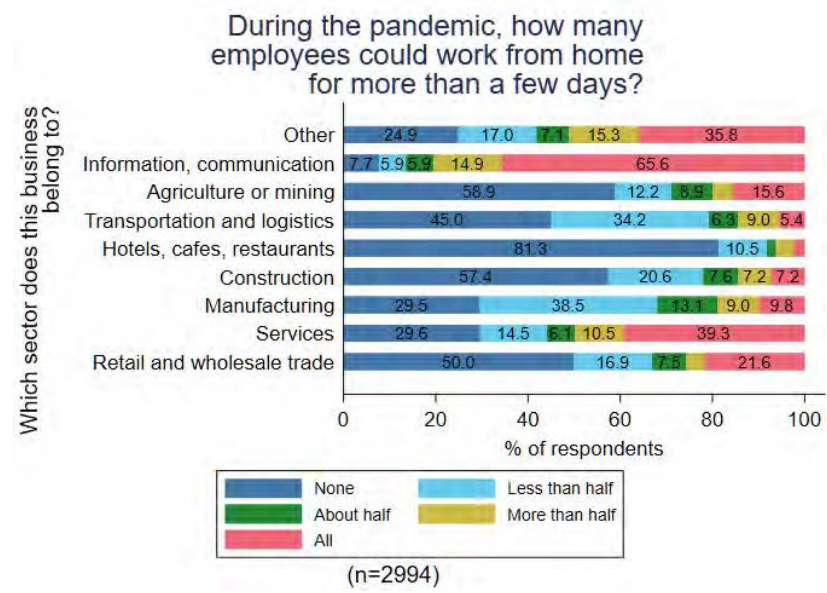

(C) Work From Home, by Sector

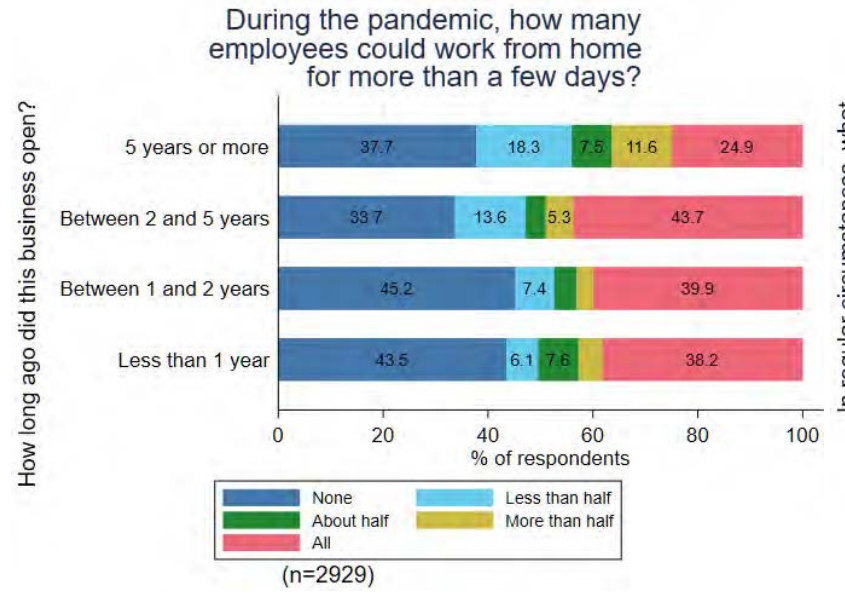

(E) Work From Home, by Firm Age

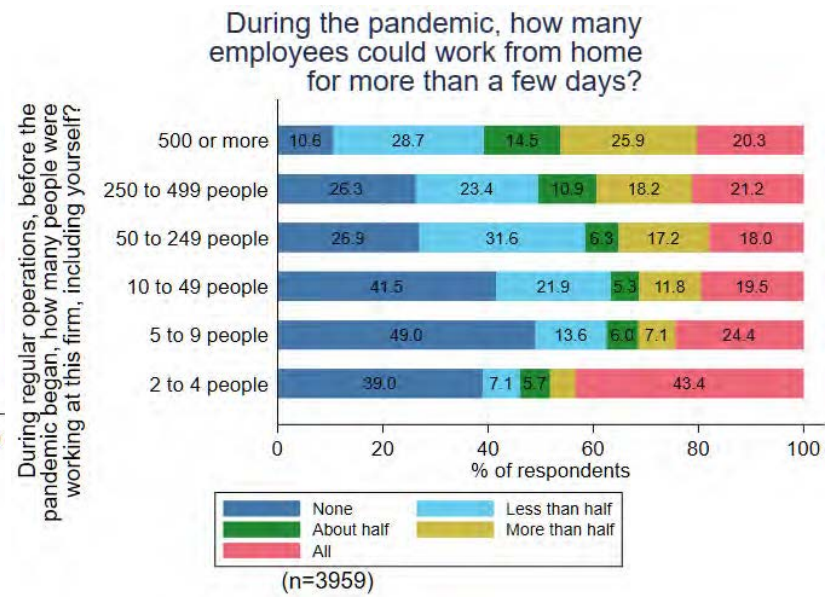

(B) Work From Home, by Employees

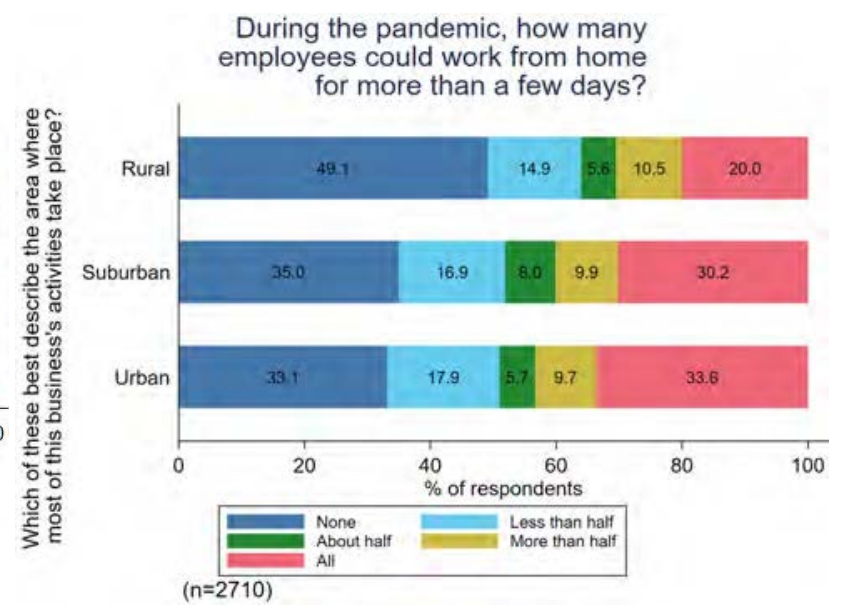

(D) Work From Home, by Area

During the pandemic, how many employees could work from home

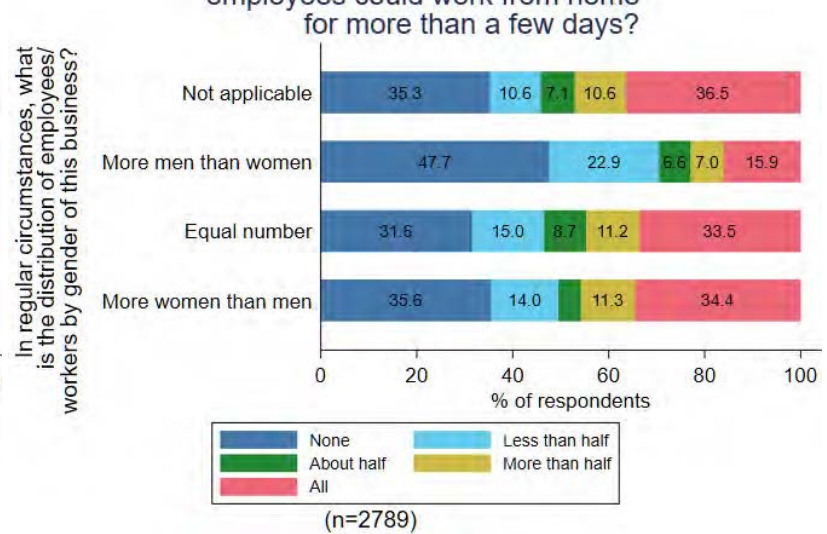

(F) Work From Home, by Gender Balance 


\section{Figure A.3: Change in Business Sales Crosstabs}

Comparing this business sales for the last 30 days with the same month last year, are this business sales?

500 or more

250 to 499 people

50 to 249 people

10 to 49 people

5 to 9 people

2 to 4 people

1 person (just me

\begin{tabular}{|l|l|}
\hline 14.0 & 5.2 \\
\hline
\end{tabular}

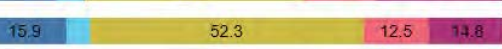

9.9 | 51.2

\begin{tabular}{|l|l|l|}
\hline 17.6 & 16.8 \\
\hline
\end{tabular}

8.6 I 61.1

66.0

$1 2 . 8 \longdiv { 1 4 3 }$

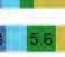

58.7

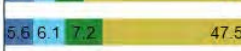

47.5

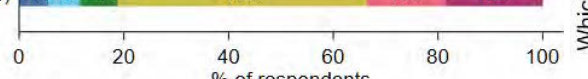
\begin{tabular}{|l|l|}
\hline Do not know & Not working here last year \\
Not operational last year & Lower than last year \\
Same as last year & Higher than last year \\
\hline
\end{tabular}

$(n=4865)$

(A) Change in Business Sales, by Business Employment

Comparing this business sales for the last 30 days with the same month last year, are this business sales?

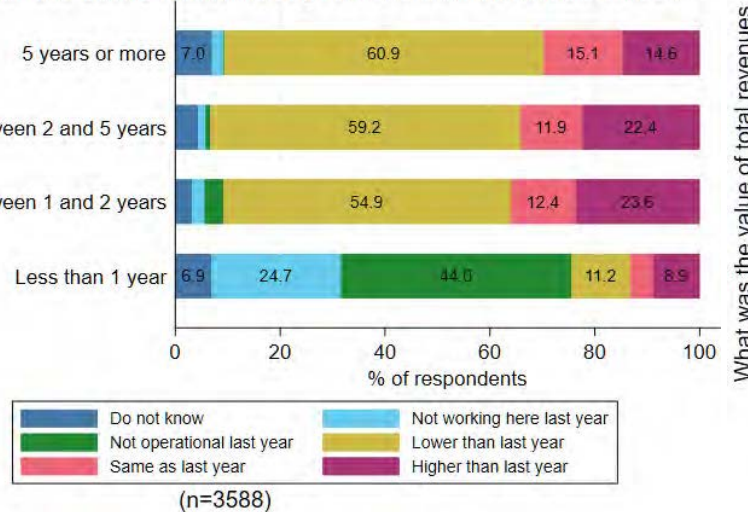

(C) Change in Business Sales, by Business Age

Comparing this business sales for the last 30 days with the same month last year, are this business sales?

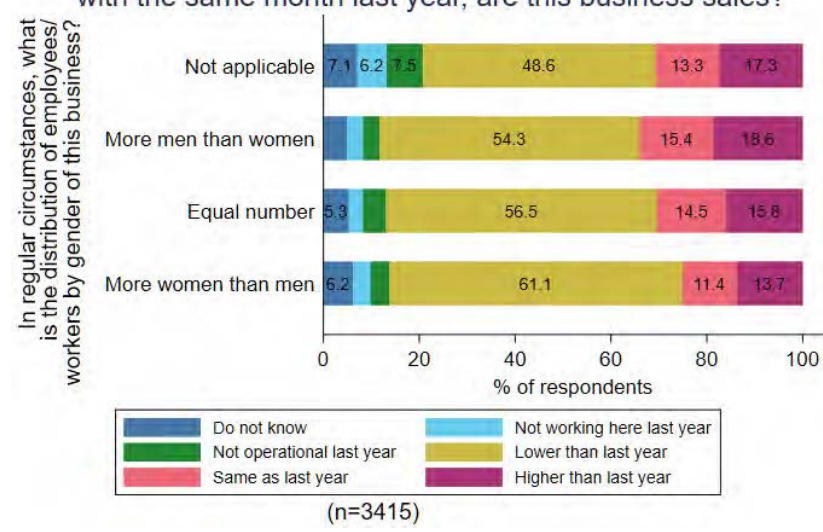

(E) Change in Business Sales, by Business Gender Balance
Comparing this business sales for the last 30 days with the same month last year, are this business sales?

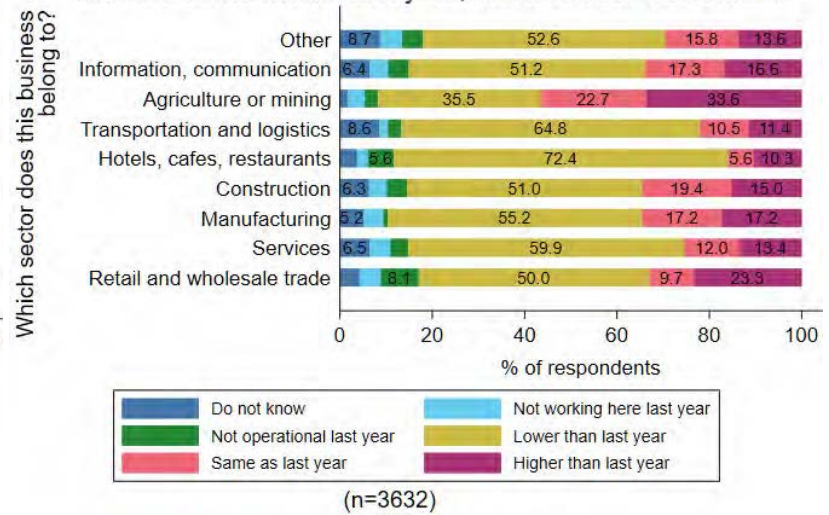

(B) Change in Business Sales, by Business Sector

Comparing this business sales for the last 30 days with the same month last year, are this business sales?

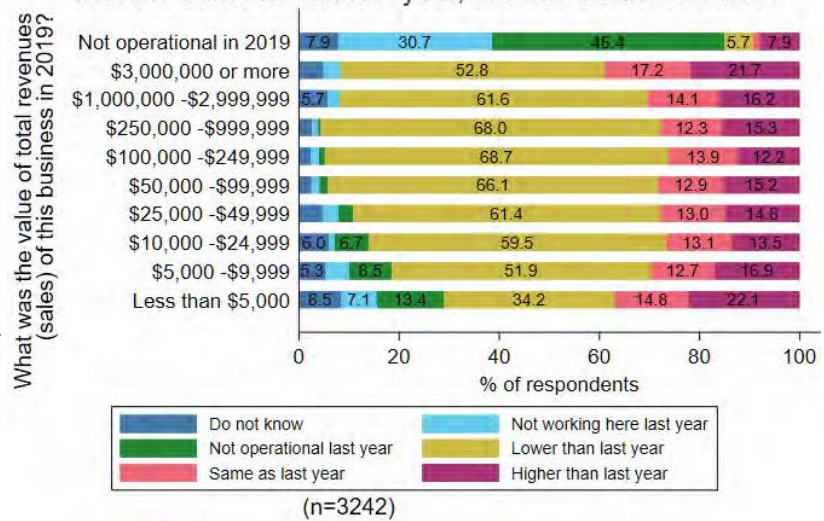

(D) Change in Business Sales, by Business Sales

Comparing this business sales for the last 30 days with the same month last year, are this business sales?

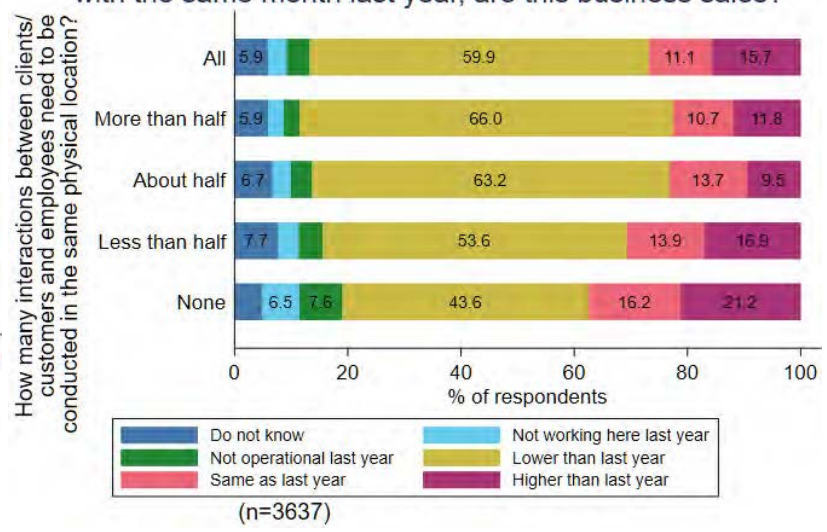

(F) Change in Business Sales, by Business In-Person Operations 
Figure A.4: Online Sales Crosstabs

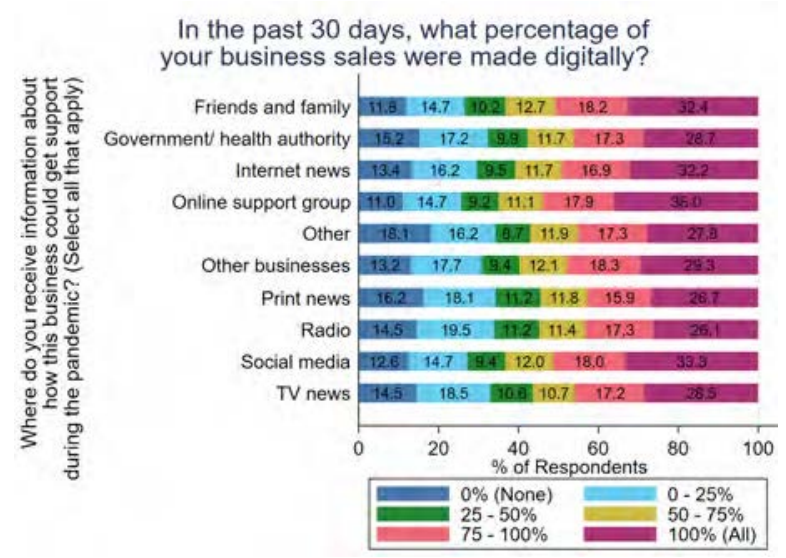

(A) Online Sales, by Information Sources

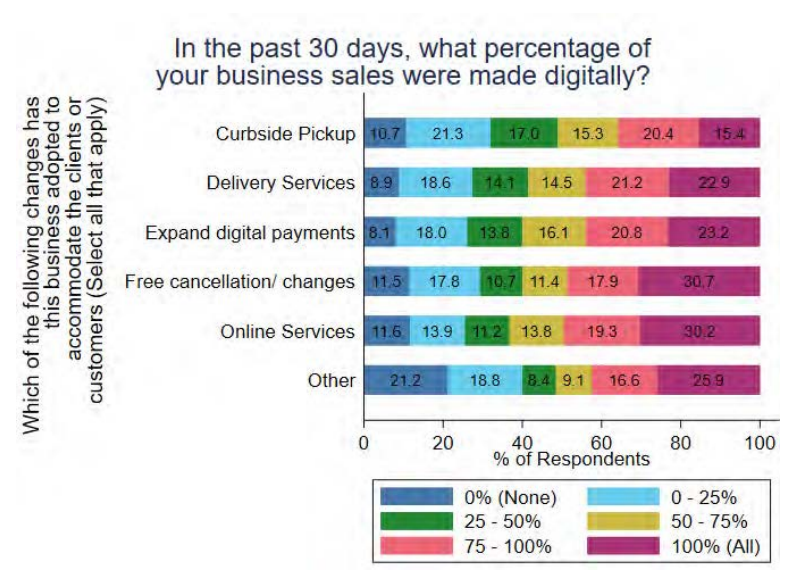

(C) Online Sales, by Client Accommodation

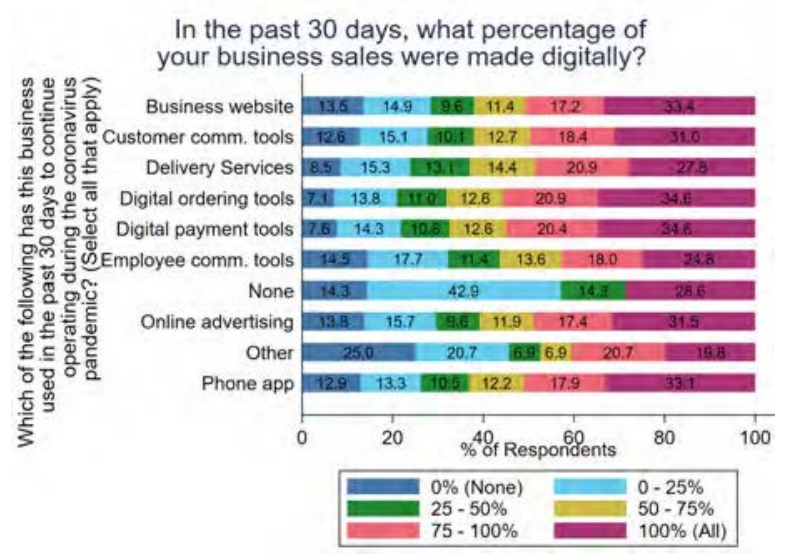

(B) Online Sales, by Business Tools 


\section{Figure A.5: Reason for Closure Crosstabs}

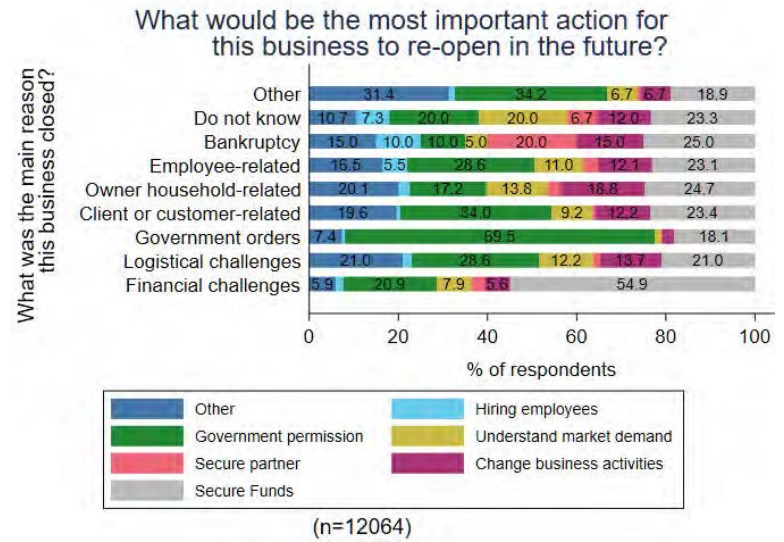

(A) Actions to Open, by Closure Reason

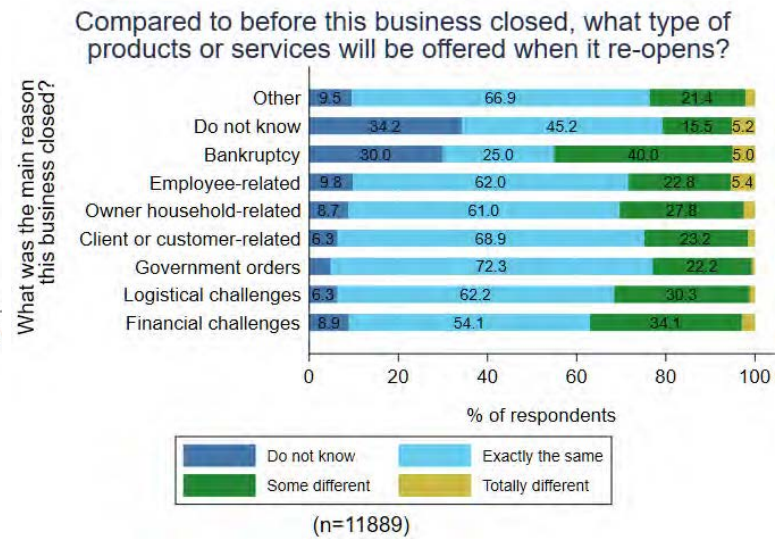

(B) Future Services, by Closure Reason

Figure A.6: Age and Educational Demographics of Employees/Workers

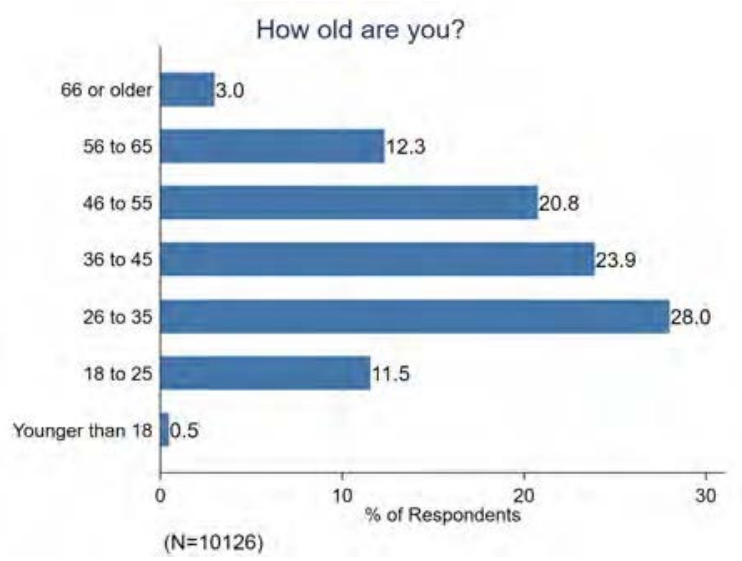

(A) Age Distribution

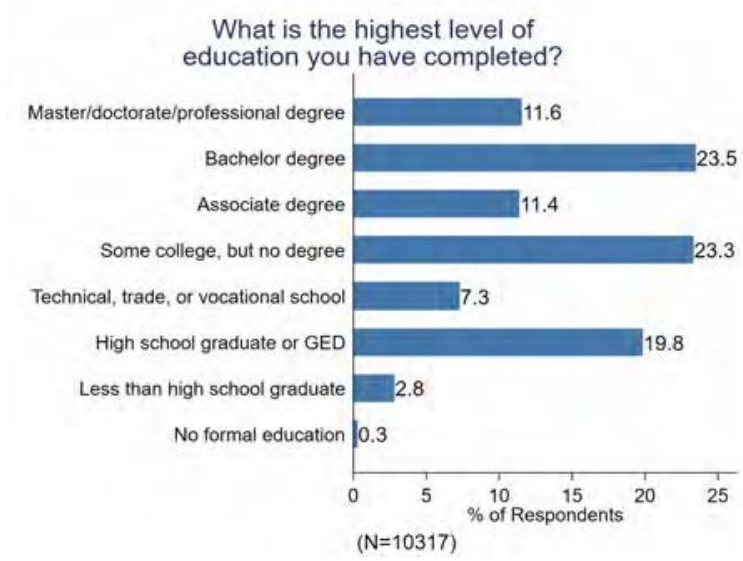

(B) Educational Distribution

Figure A.7: Sectors of Employees/Workers

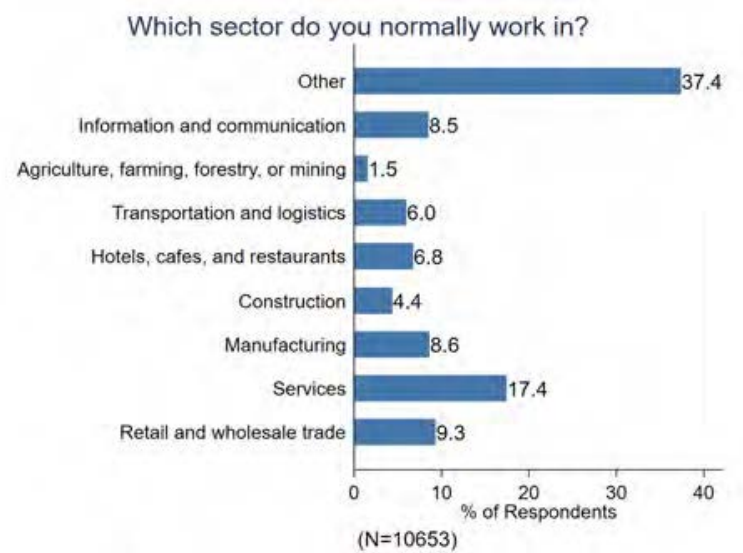


Figure A.8: Employment Types of Respondents who currently have a Job

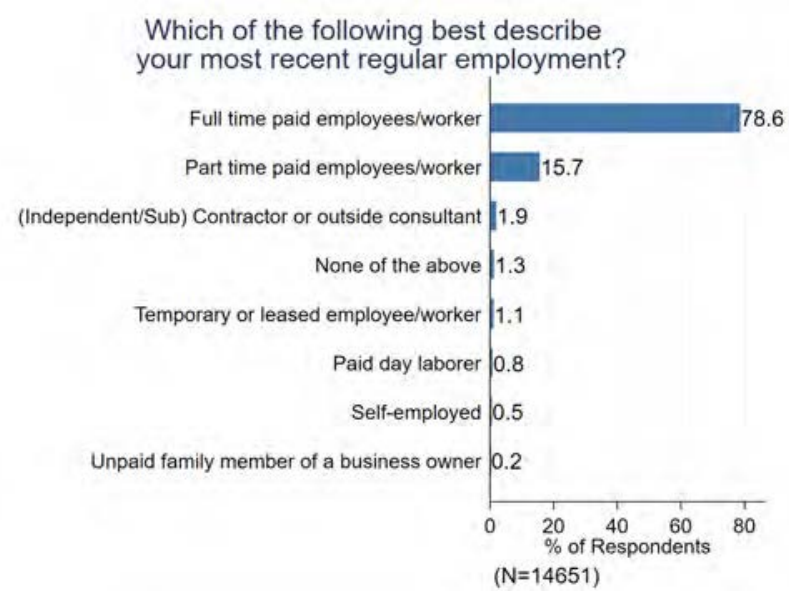

Figure A.9: Geographical Distribution of Employee/Worker Respondents

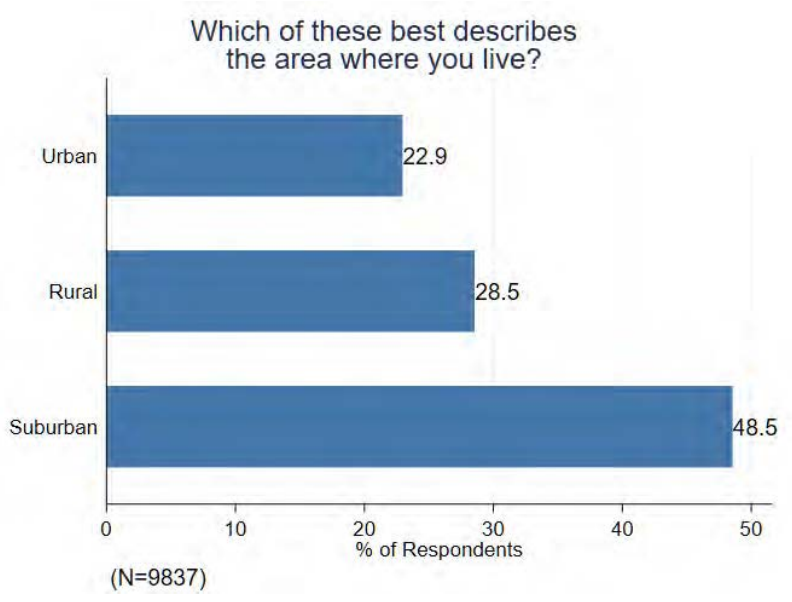




\section{Figure A.10: Time Spent on Household Activities}

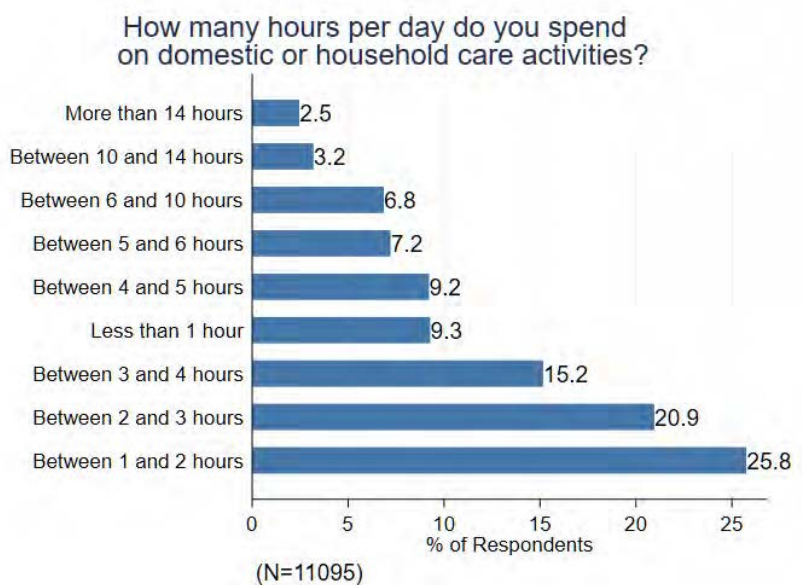

(A) Time Spend on Household Activities

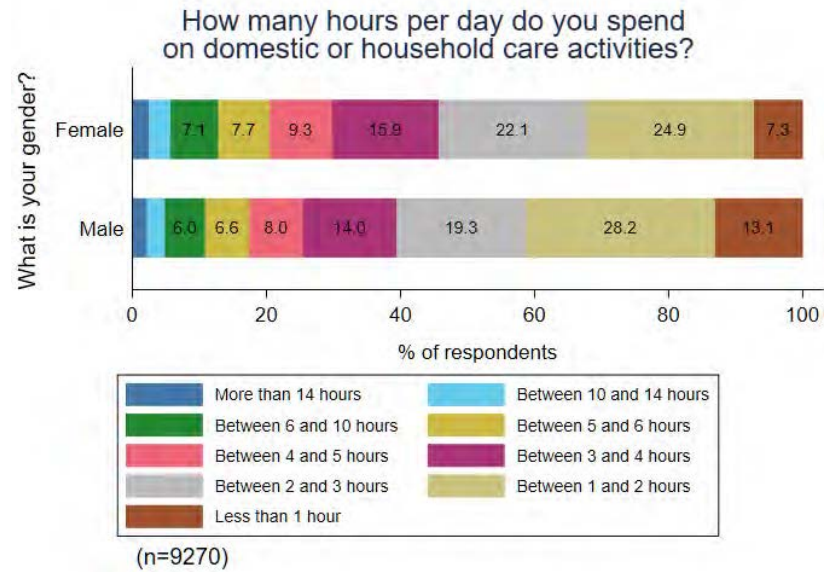

(C) Time Spend on Household Activities, by Gender

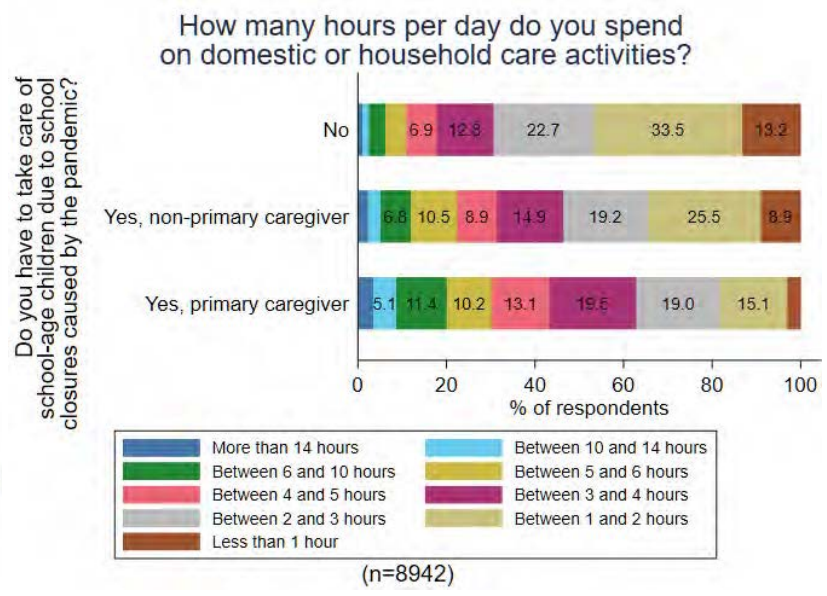

(B) Time Spend on Household Activities, by Parental Status

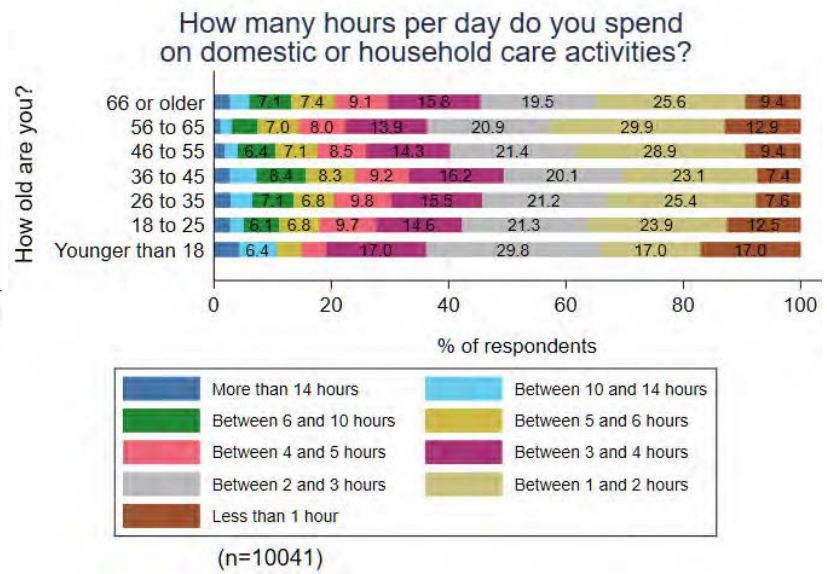

(D) Time Spend on Household Activities, by Age 


\section{Figure A.11: Employee/Worker Income}

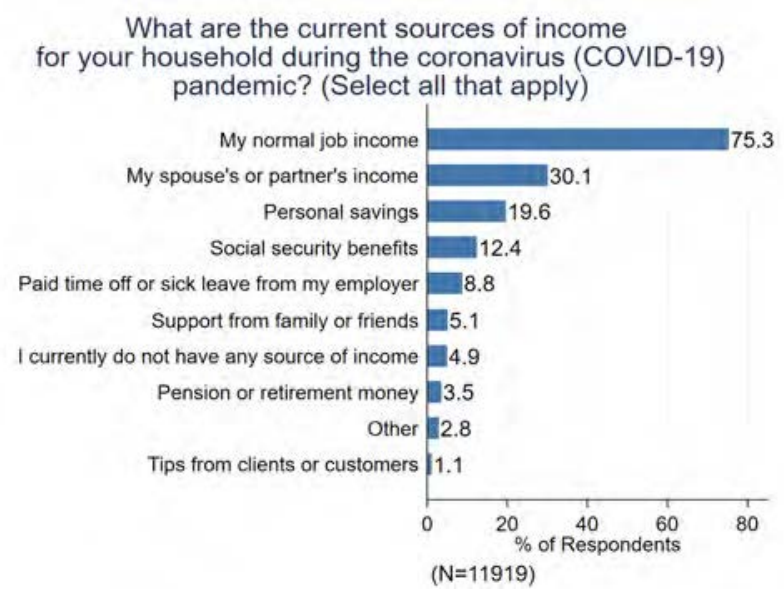

(A) Income Sources, Respondent is Employed

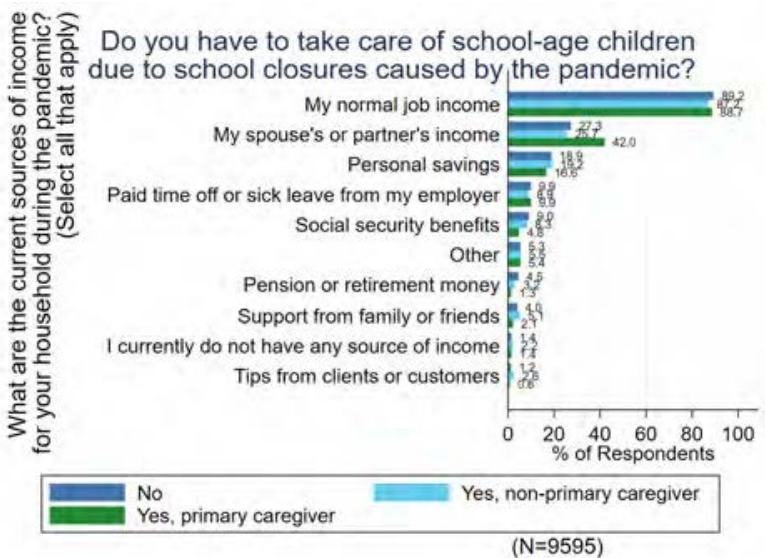

(B) Income Sources, by having Children

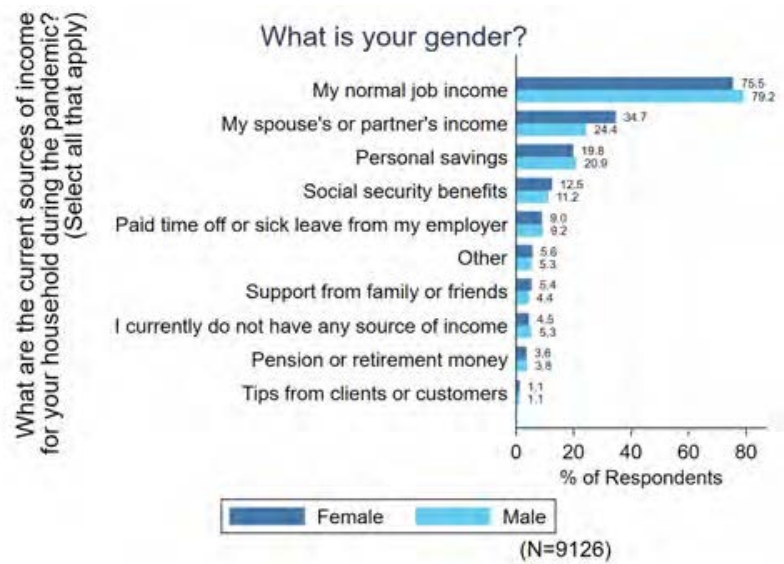

(C) Income Sources, by Gender 


\section{Figure A.12: Employee/Worker Benefits}

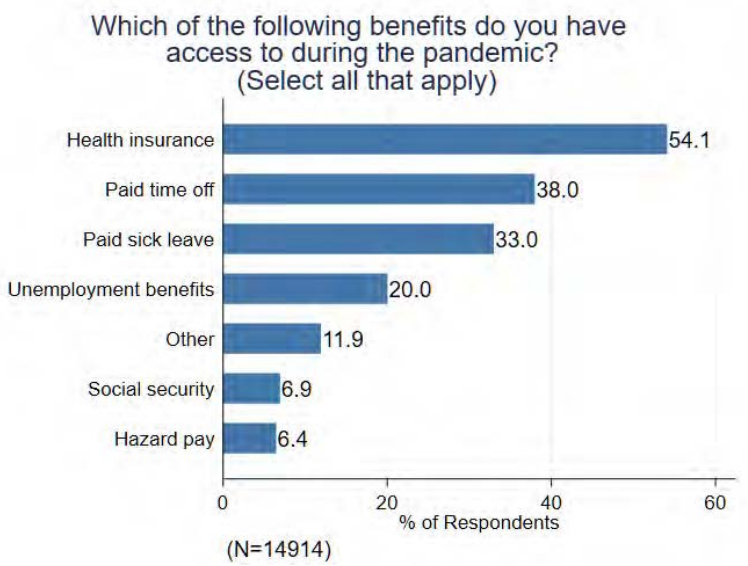

(A) Employee/Worker Benefits

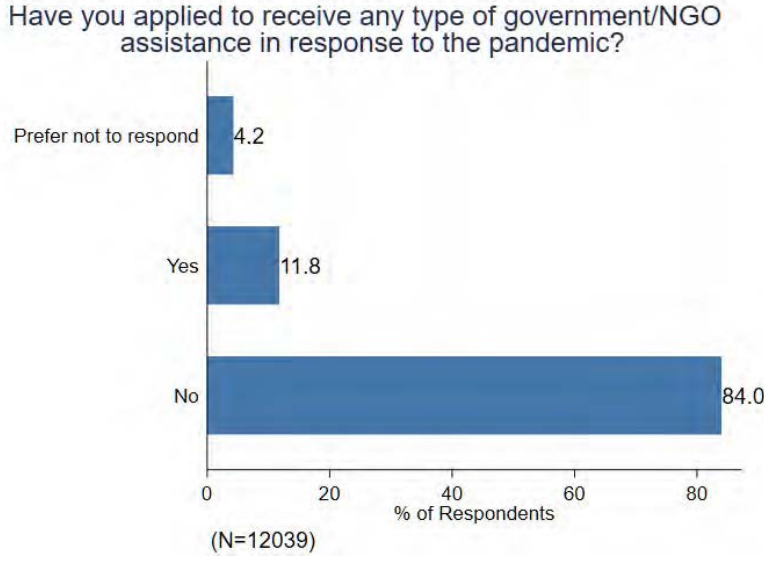

(B) Applications for Government/NGO Assistance

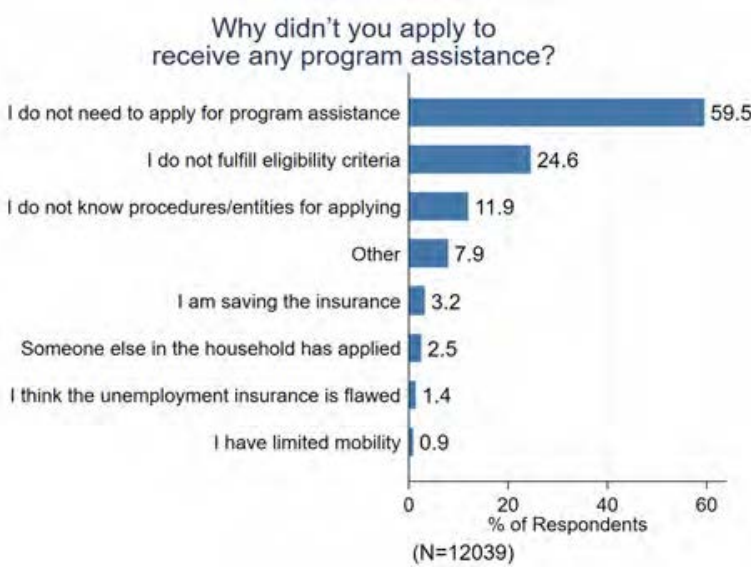

(D) Reasons for Not Applying
Have you applied to receive any type of government/NGO

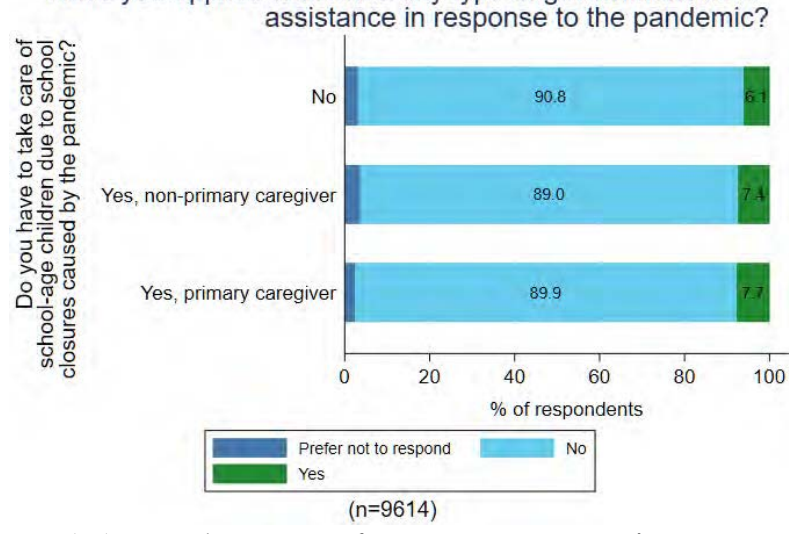

(C) Applications for Government/NGO Assistance, by having Children

Which of the following types of government or NGO assistance are you receiving in response to the pandemic? (Select all that apply)

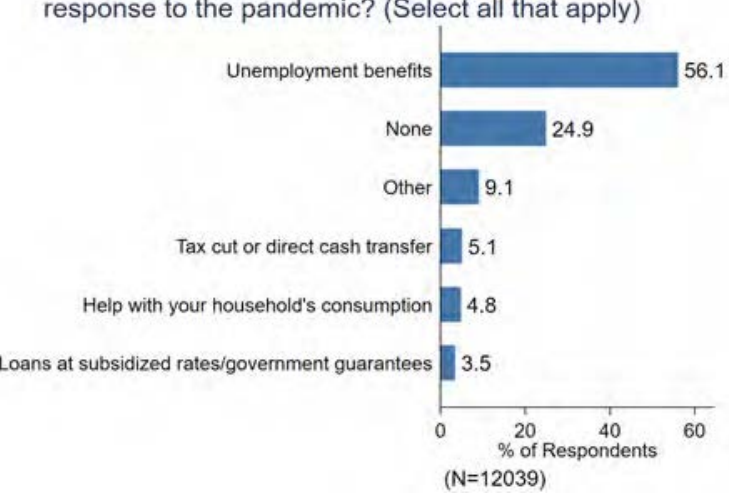

(E) Government/NGO Assistance for Applicants 


\section{Figure A.13: Employee/Worker Concerns}

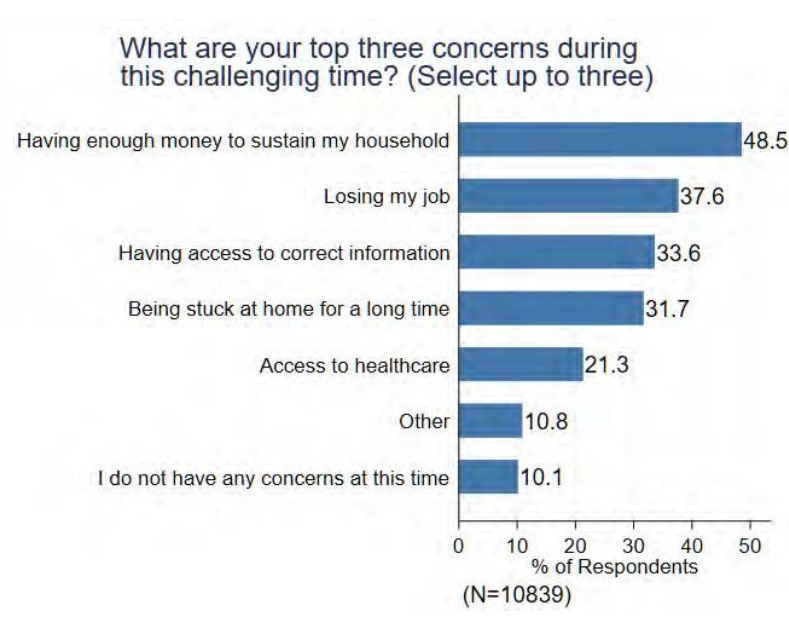

(A) Top Self-reported Concerns

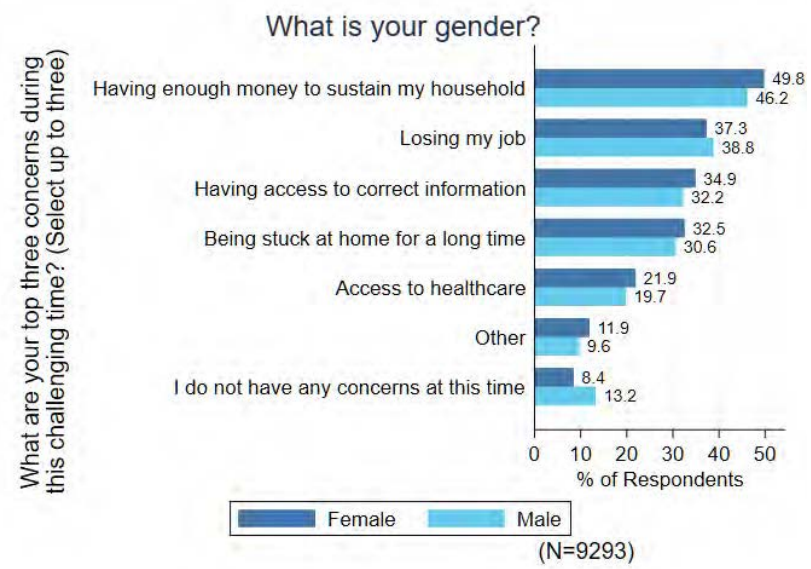

(C) Top Self-reported Concerns, by Gender

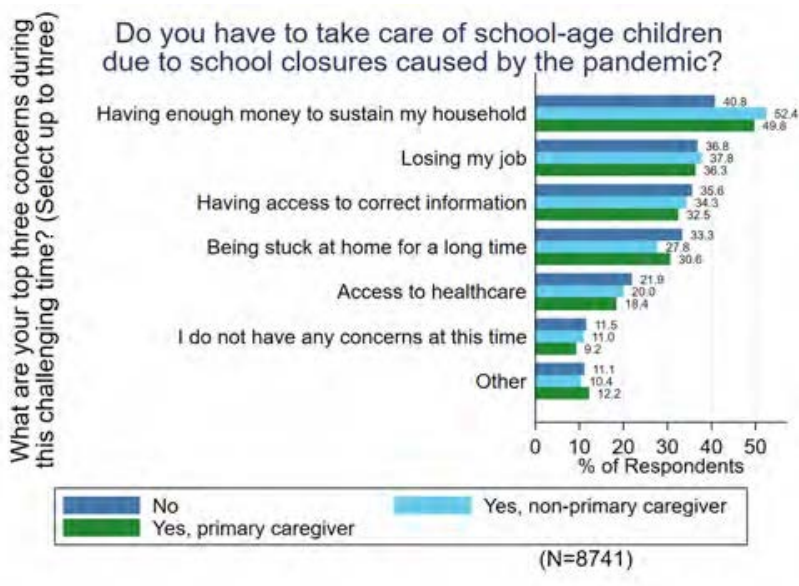

(B) Top Self-reported Concerns, by having Children 


\section{A.VI FiguRES - SMALl Business EMPloyeEs ONLY}

\section{Figure A.14: Employee/Worker Self-reported Main Reason for Unemployment}

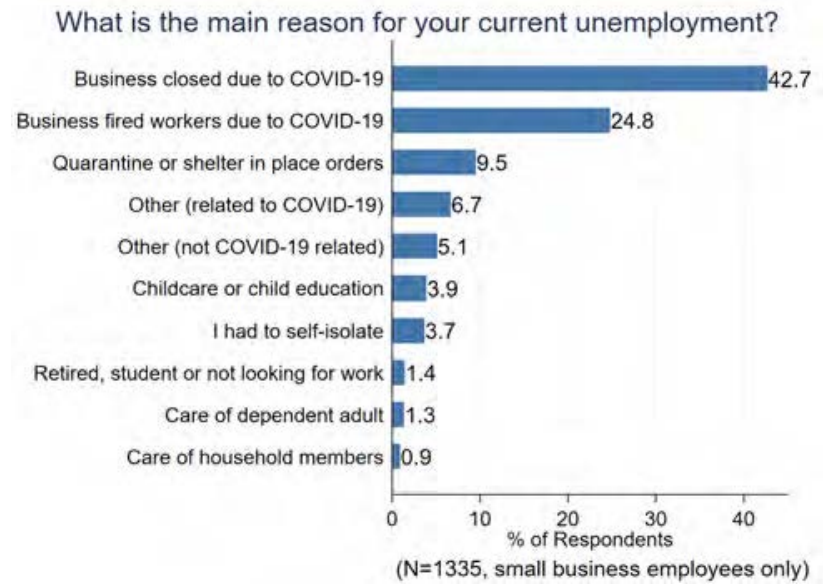

(A) Main Reason

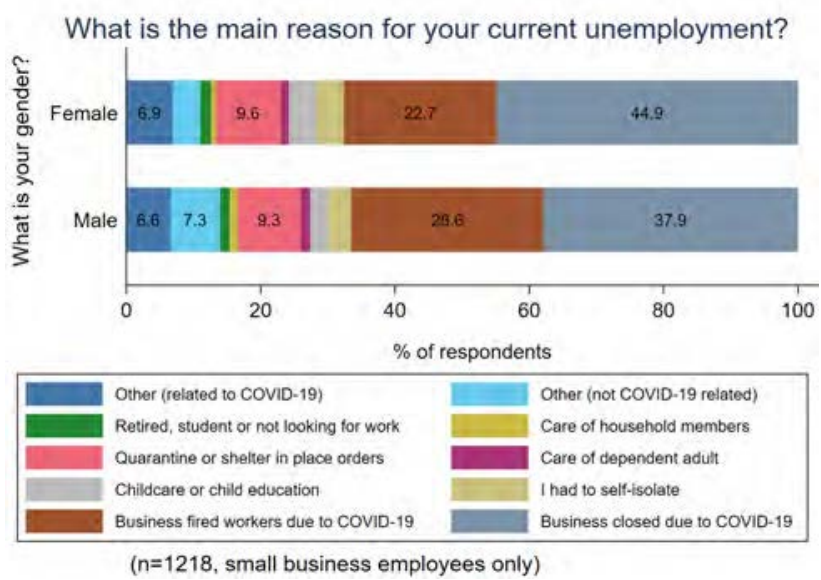

(B) Main Reason, by Gender 
Figure A.15: Employee/Worker Unemployment Demographics

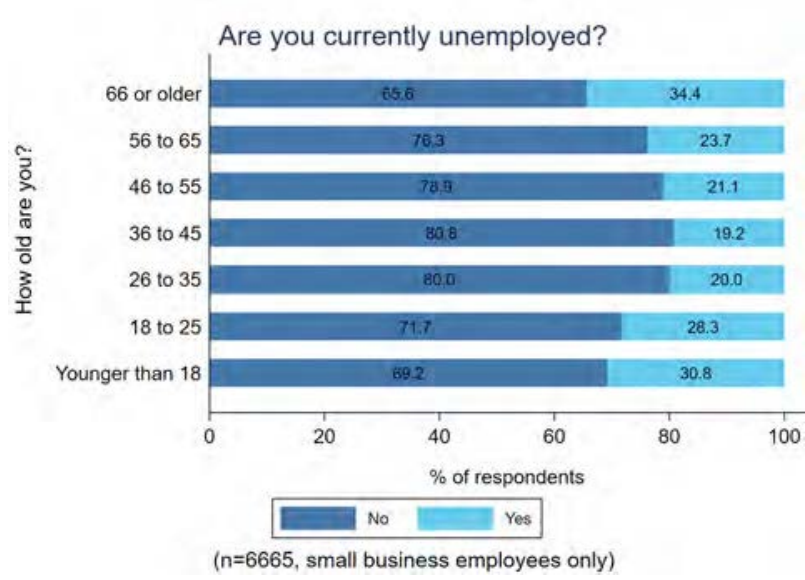

(A) Fraction Unemployed, by Age

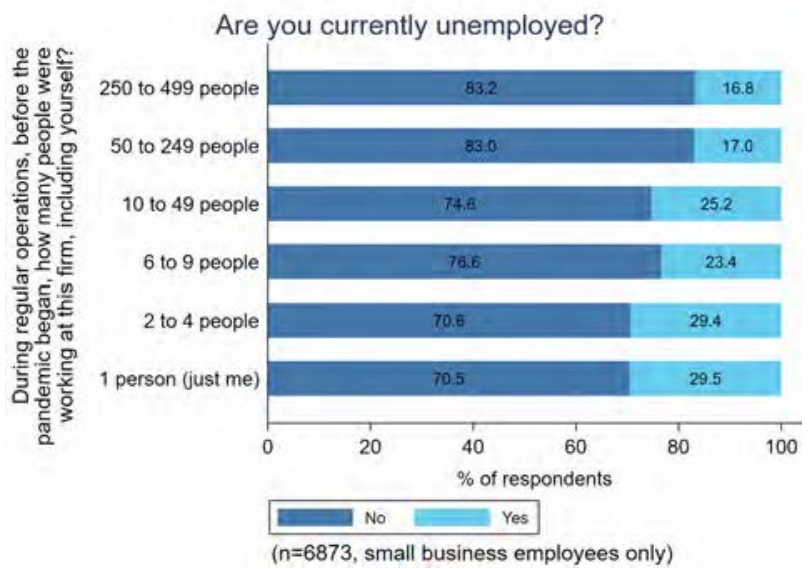

(C) Fraction Unemployed, by Size of Most Recent Company

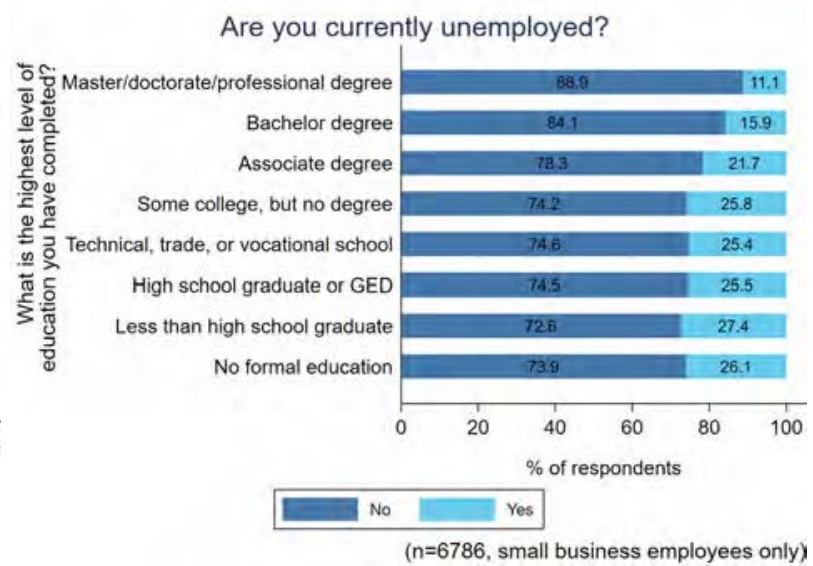

(B) Fraction Unemployed, by Educational Background

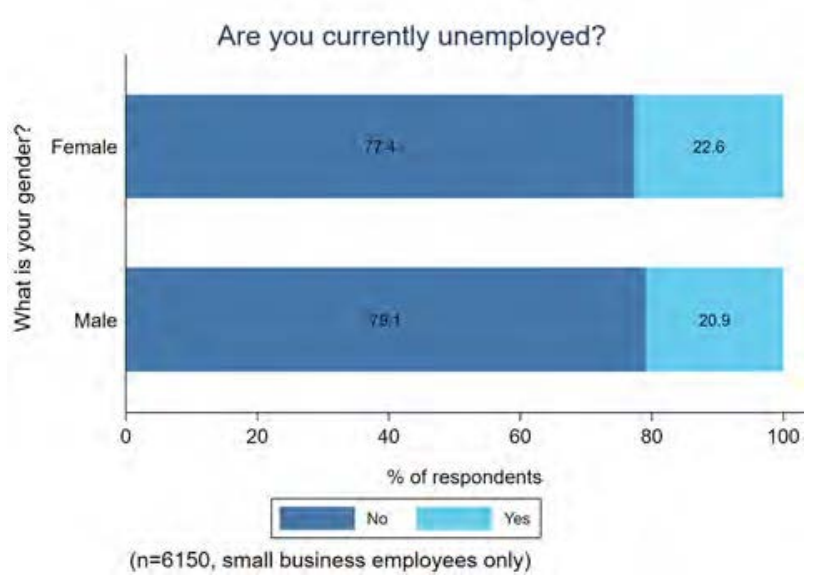

(D) Fraction Unemployed, by Gender

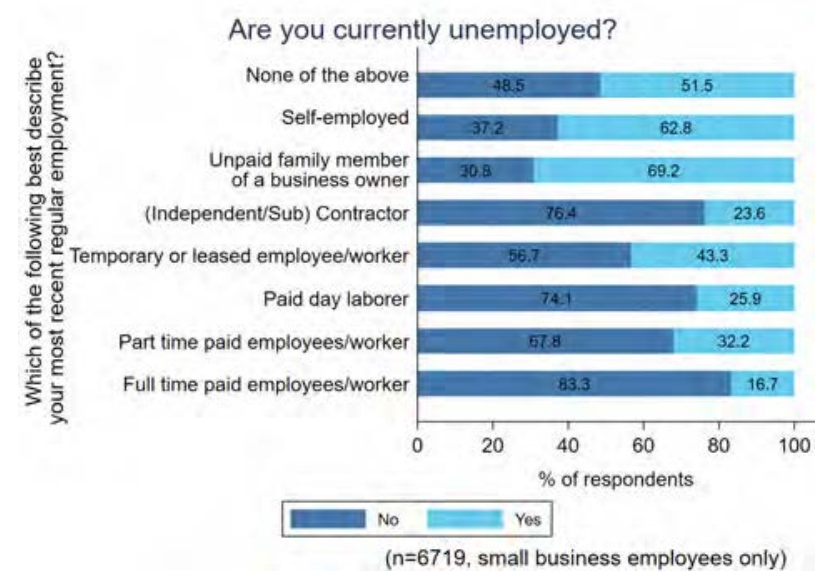

(E) Fraction Unemployed, by Most Regular

Employment 
Figure A.16: Employee/Worker Activities during Unemployment

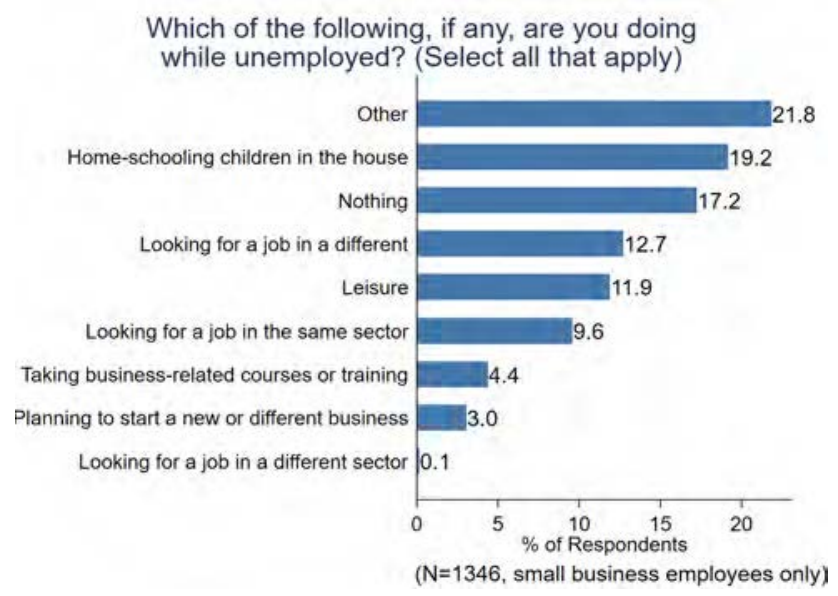

Figure A.17: Government/NGO Assistance for Unemployed

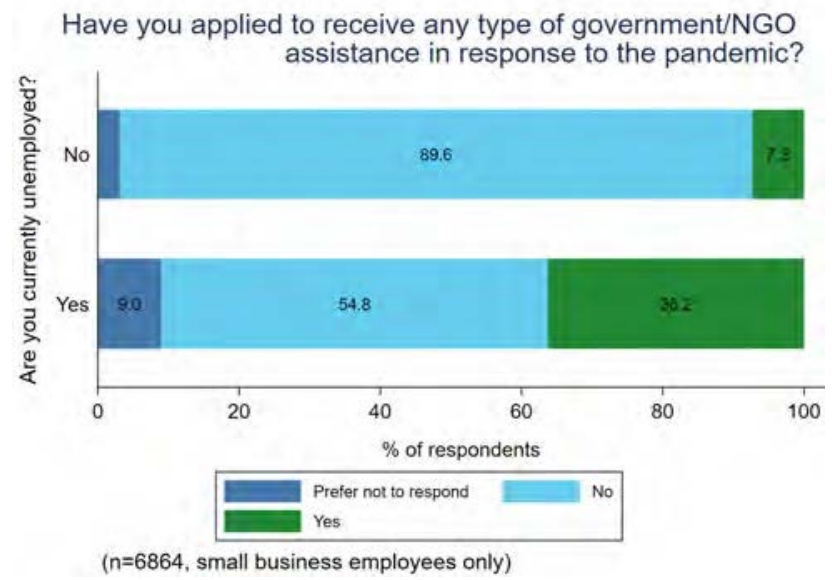

(A) Government/NGO Assistance Applications, by Unemployment Status

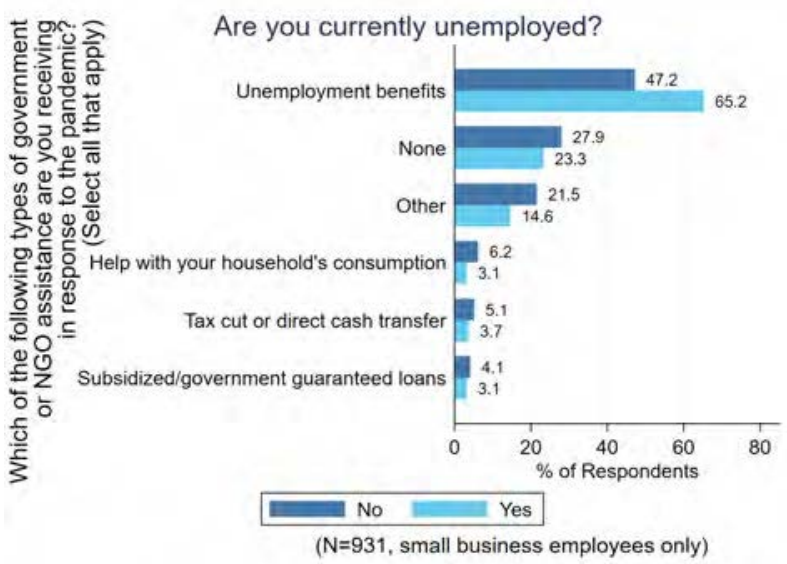

(B) Types of Government Support Receiving, by Unemployment Status

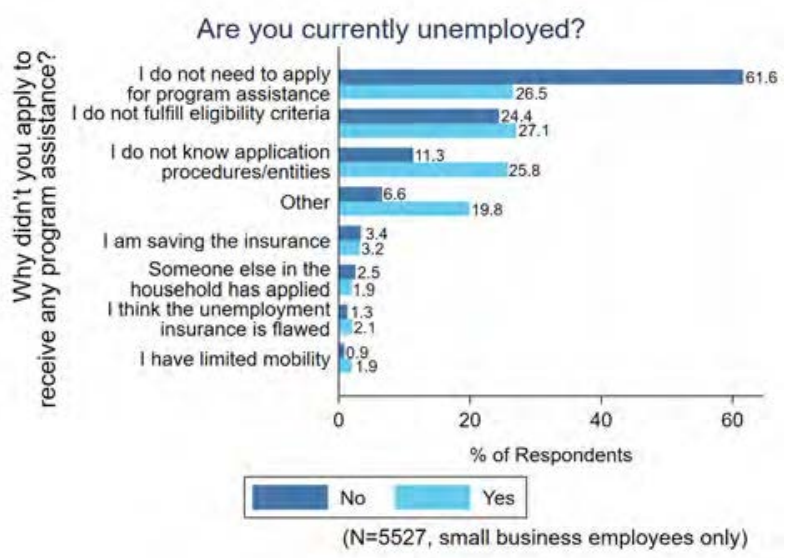

(C) Reasons for not Applying for Government Assistance, by Unemployment Category 
Figure A.18: Household Care Responsibilities

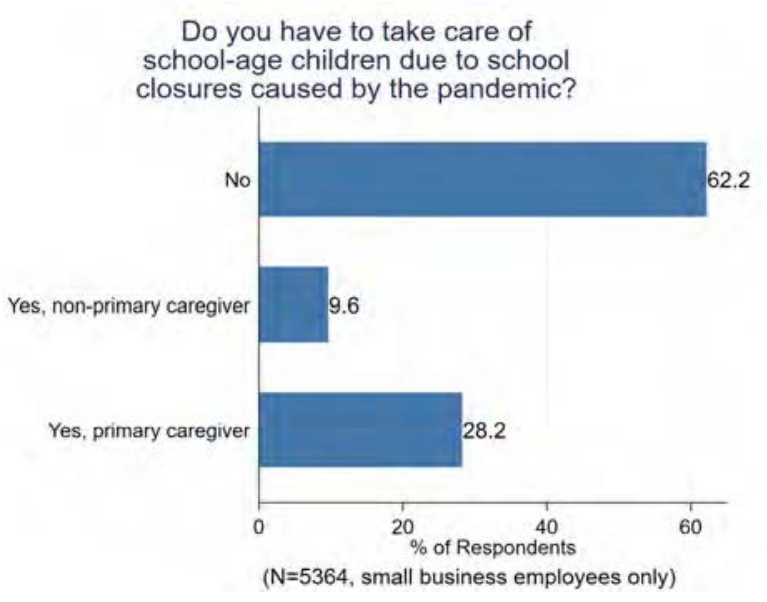

(A) Childcare due to School Closures

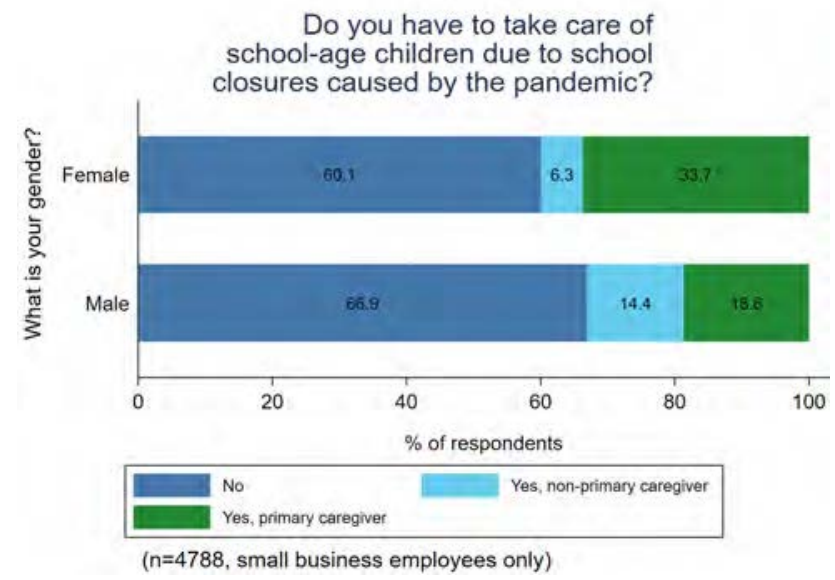

(C) Childcare due to School Closures, by Gender

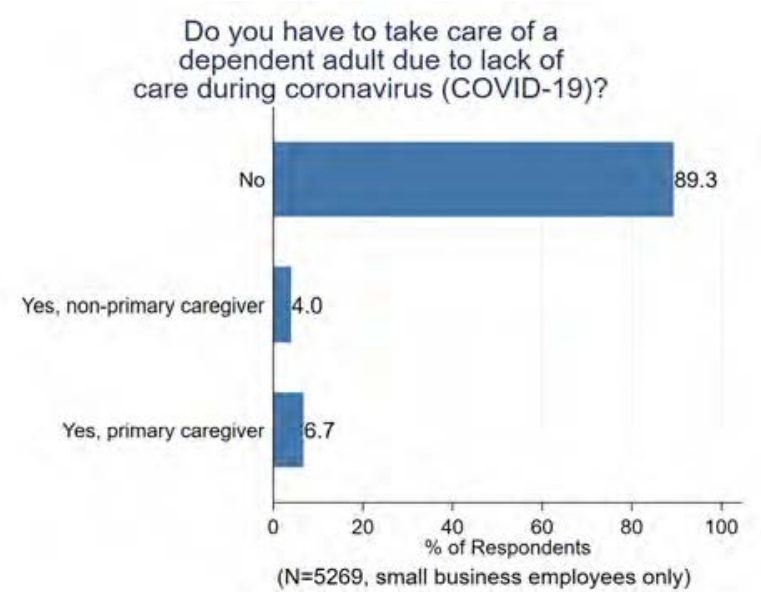

(B) Care of a Dependent Adult

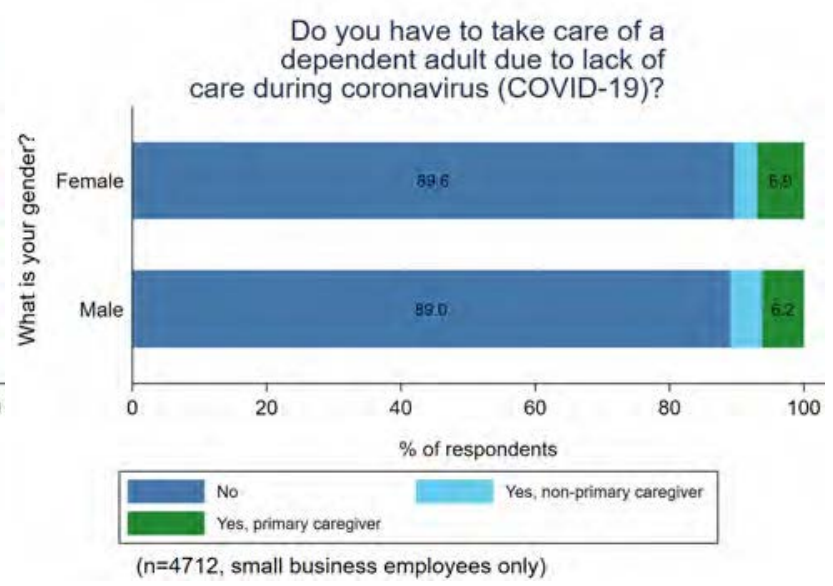

(D) Care of a Dependent Adult, by Gender 


\section{Figure A.19: Employee/Worker: Household Impact on Job}

How much have your household responsibilities affected your ability to focus on your work during the pandemic?

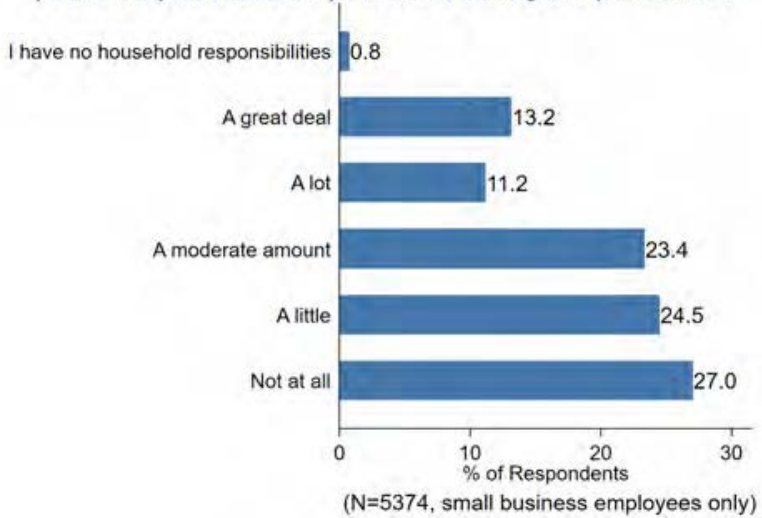

(A) Household Impact on Job

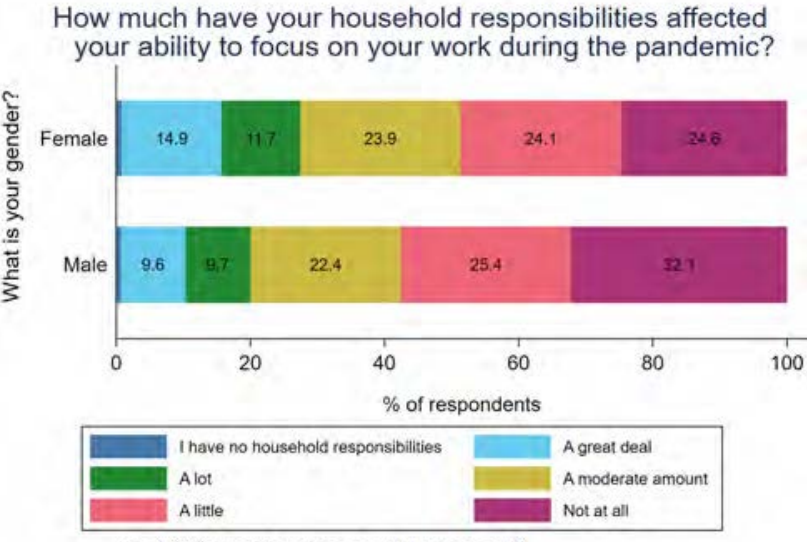

(C) Household Impact on Job, by Gender

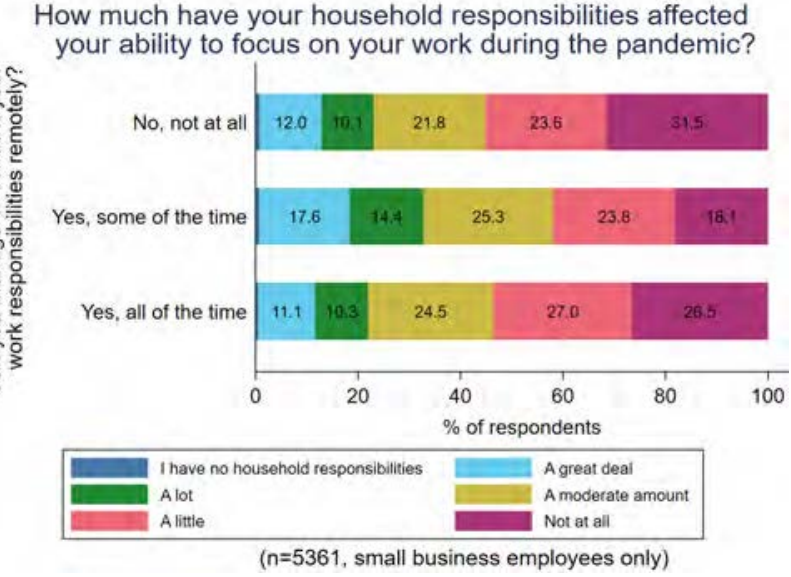

(E) Household Impact on Job, by Work From

Home

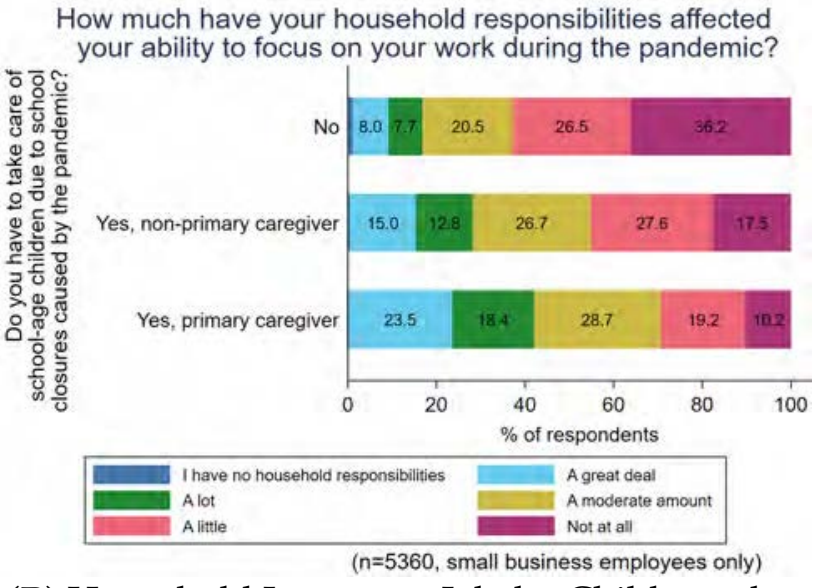

(B) Household Impact on Job, by Childcare due to School Closures

How much have your household responsibilities affected your ability to focus on your work during the pandemic?

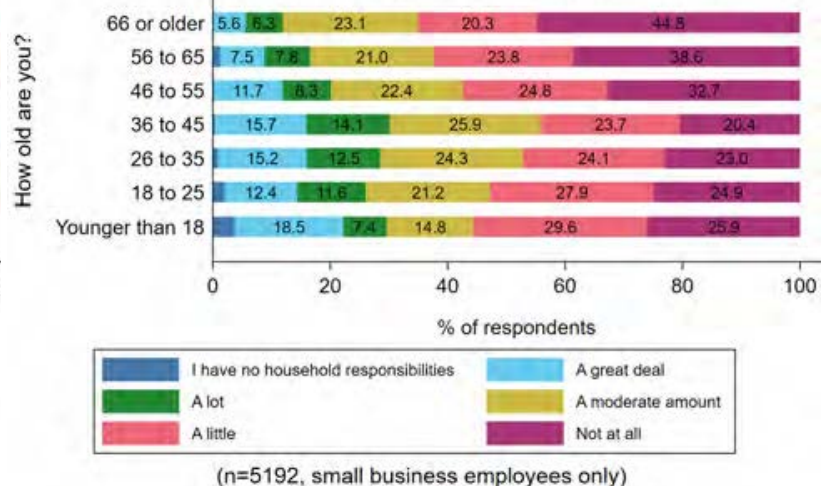

(D) Household Impact on Job, by Age 
Figure A.20: Employee/Worker: Job Impact on Household

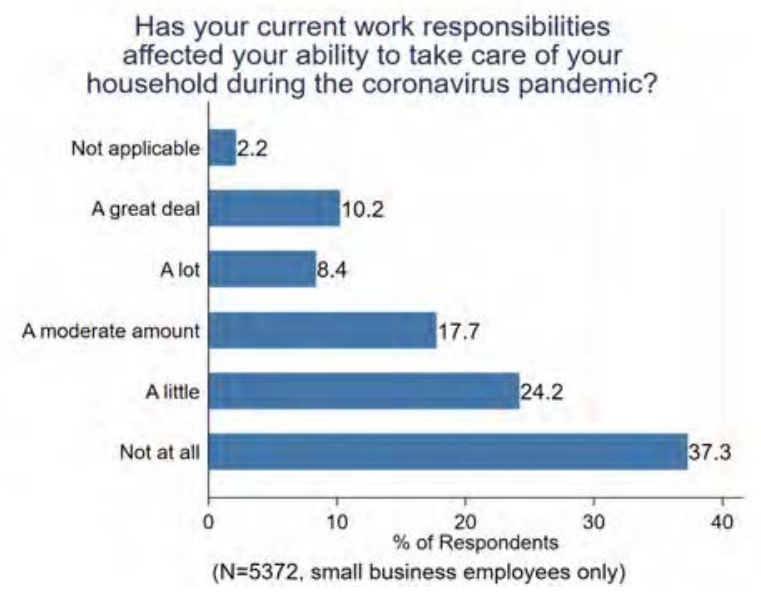

Figure A.21: Employee/Worker: Remote Work

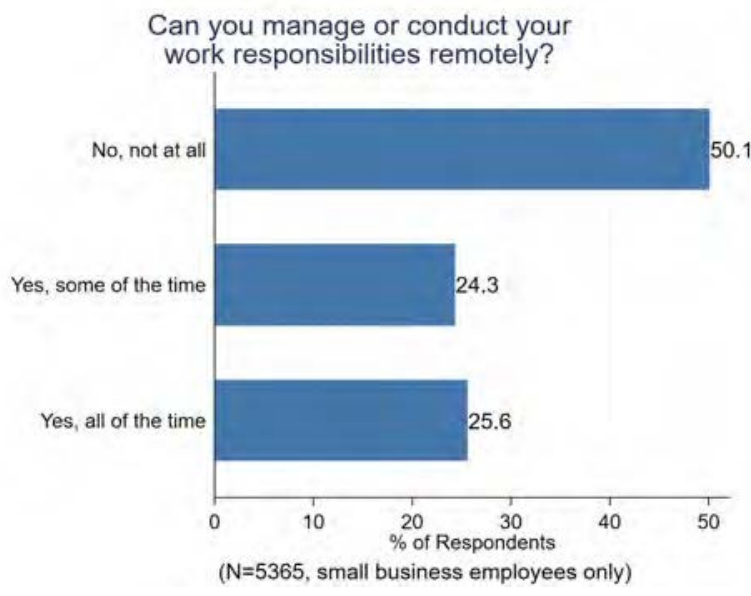

(A) Remote Work

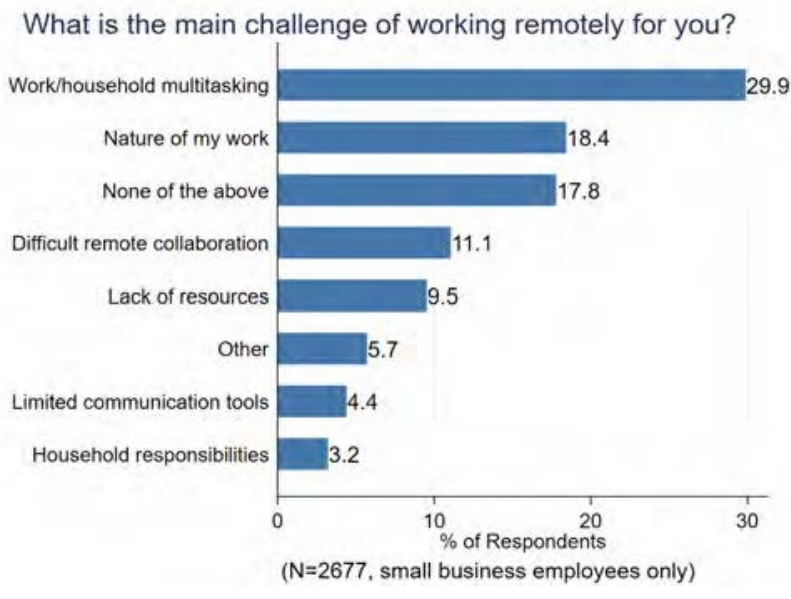

(B) Main Challenge in Working Remotely 
Figure A.22: Employee/Worker Remote Work Challenges

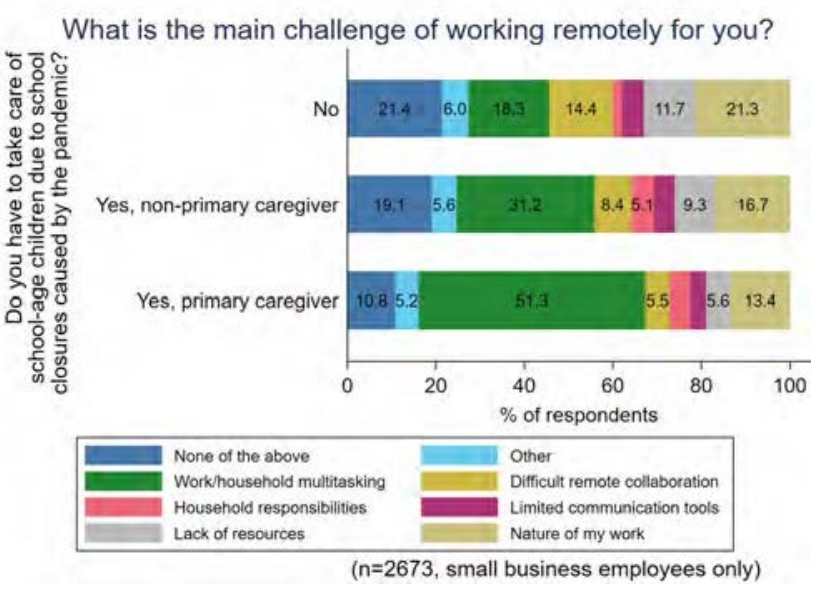

(A) Main Challenge in Working Remotely, by Childcare due to School Closures

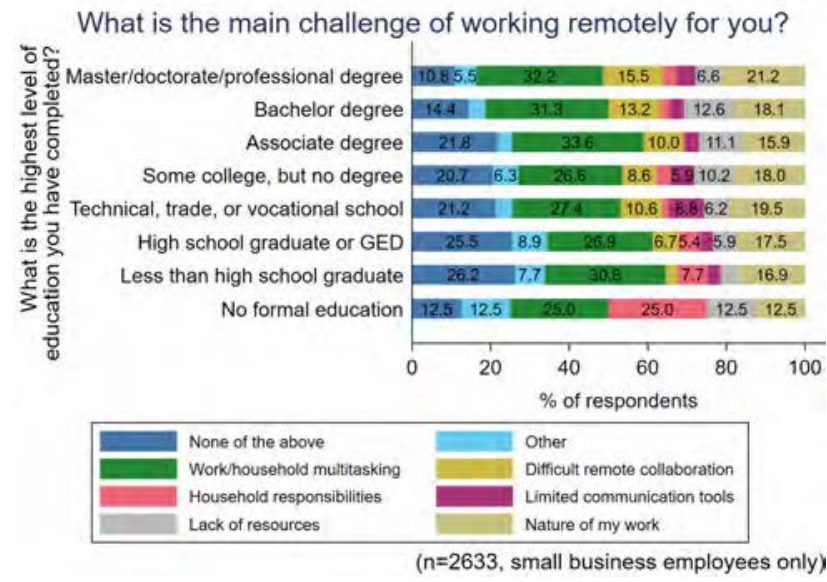

(C) Main Challenge in Working Remotely, by Education

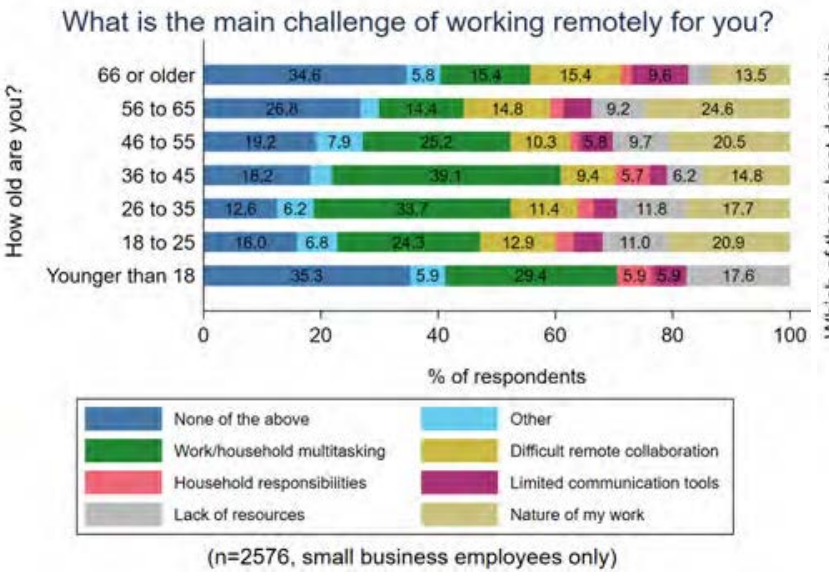

(E) Main Challenge in Working Remotely, by Age

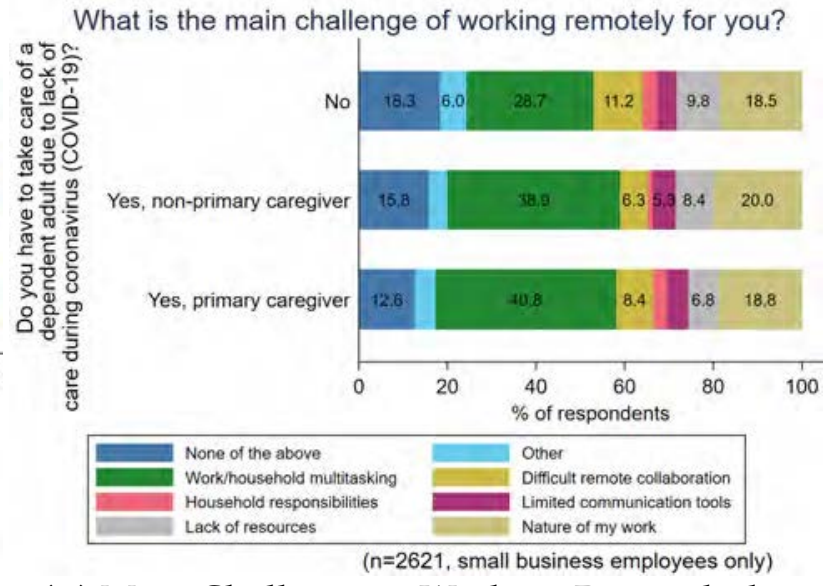

(B) Main Challenge in Working Remotely, by Care for a Dependent Adult

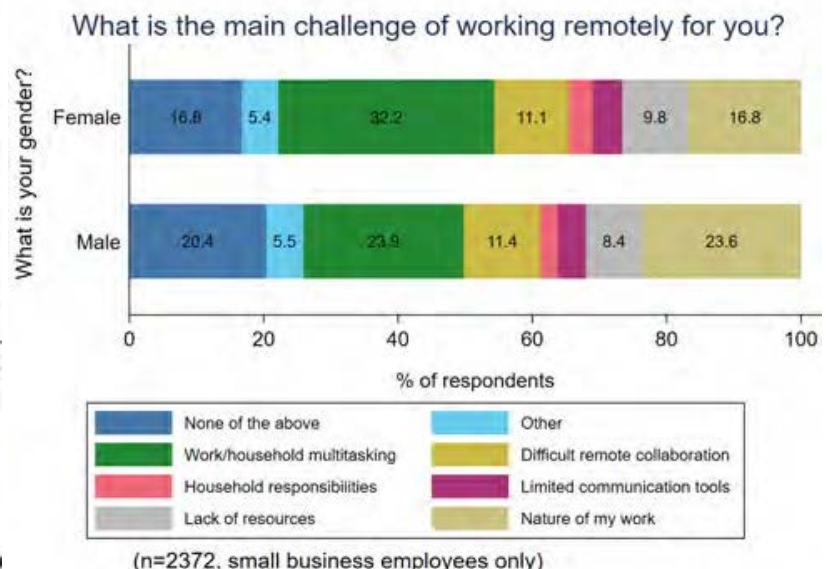

(D) Main Challenge in Working Remotely, by Gender

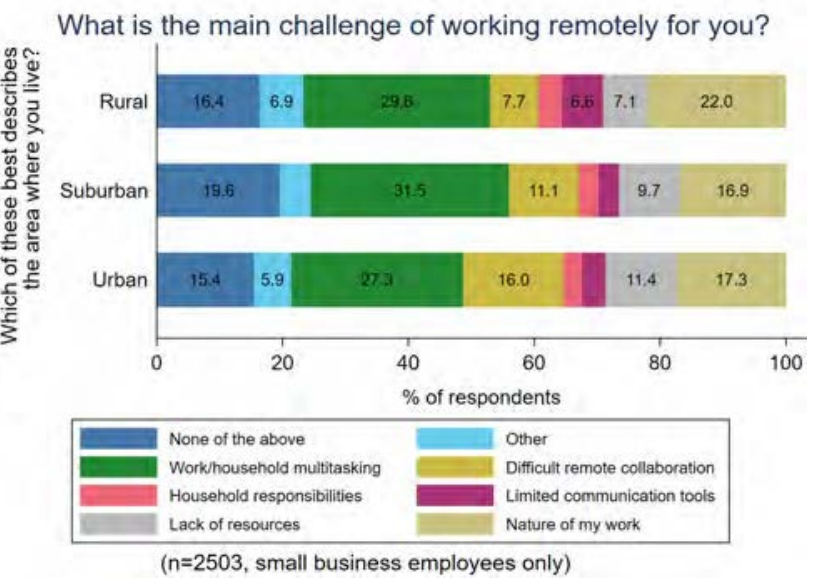

(F) Main Challenge in Working Remotely, by Area 
Figure A.23: Employee/Worker: News Sources during the Pandemic

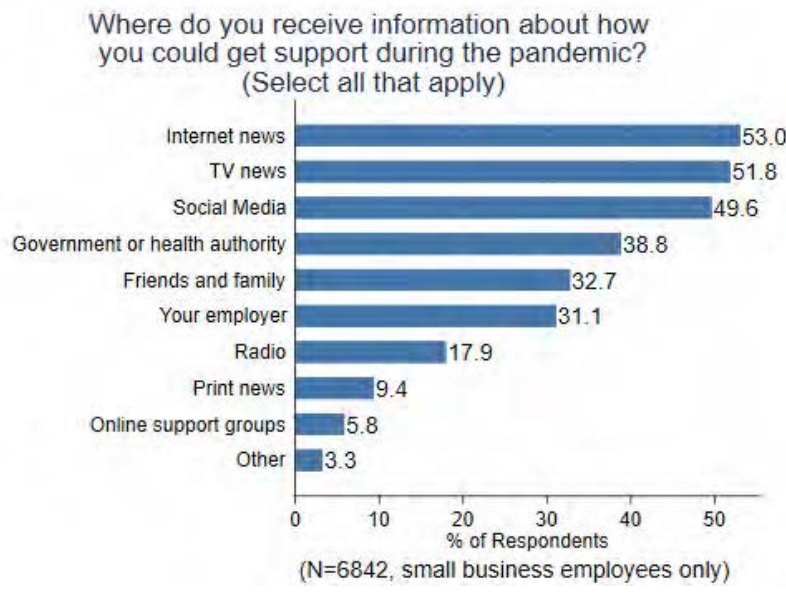


Figure A.24: Employee/Worker: Optimism about Future Employment

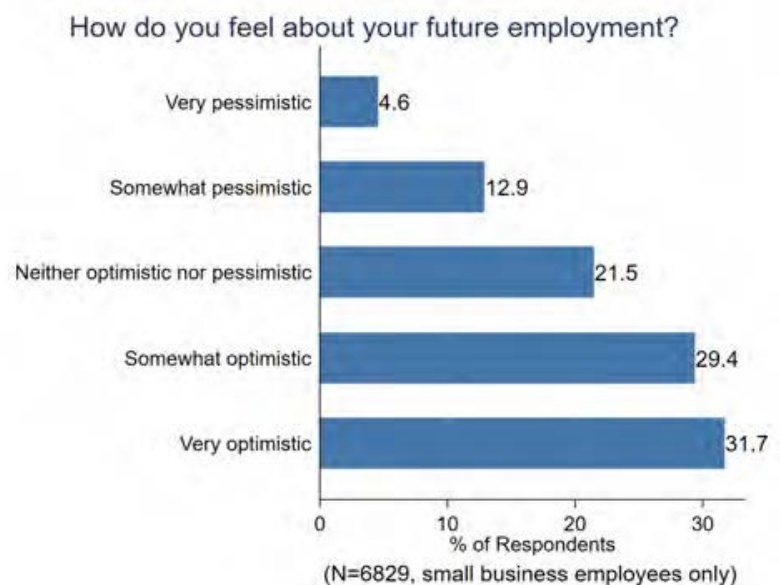

(A) Optimism about Future Employment

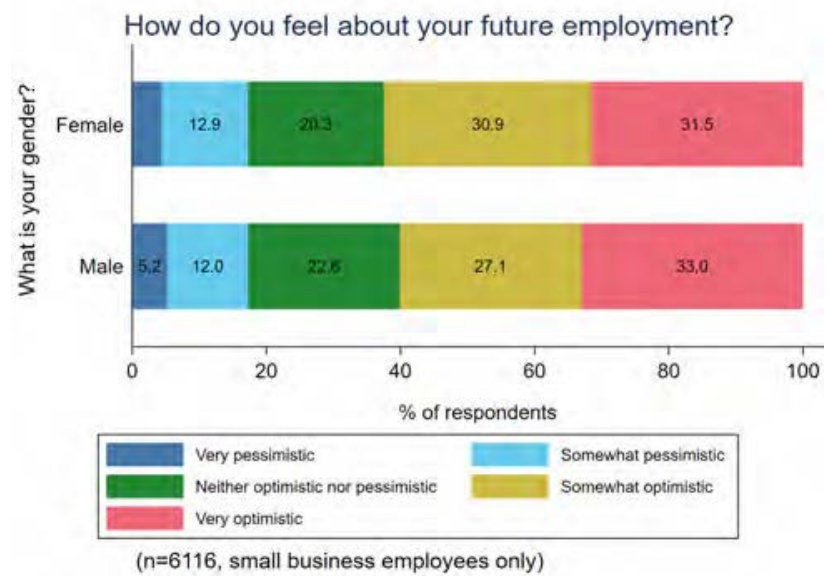

(C) Optimism about Future Employment, by Gender

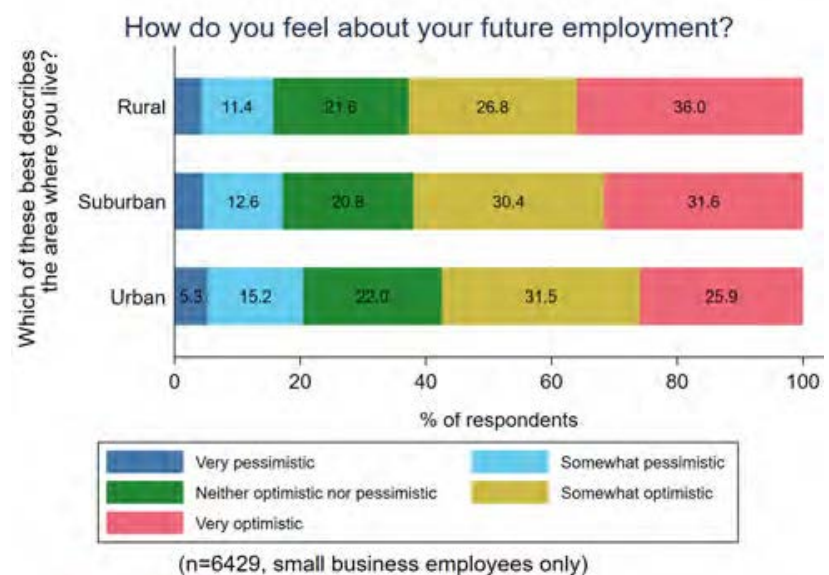

(E) Optimism about Future Employment, by Area
How do you feel about your future employment?

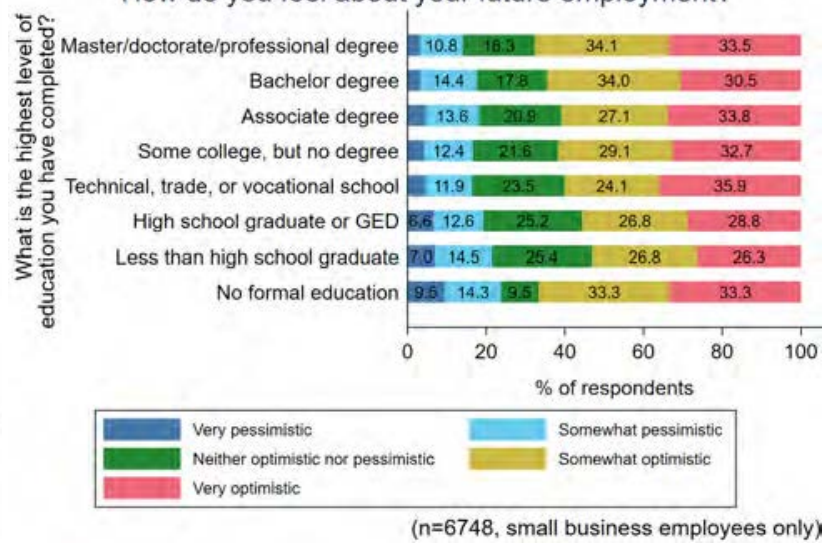

(B) Optimism about Future Employment, by Education

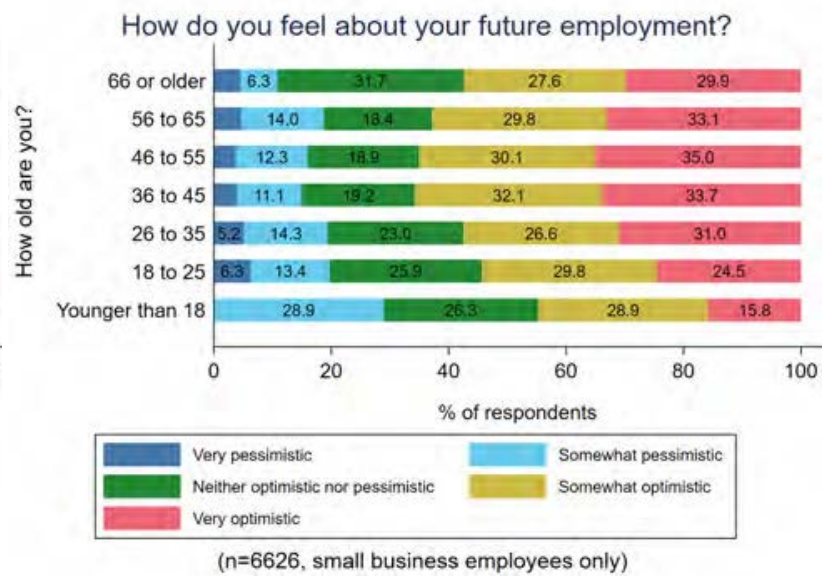

(D) Optimism about Future Employment, by Age

How do you feel about your future employment?

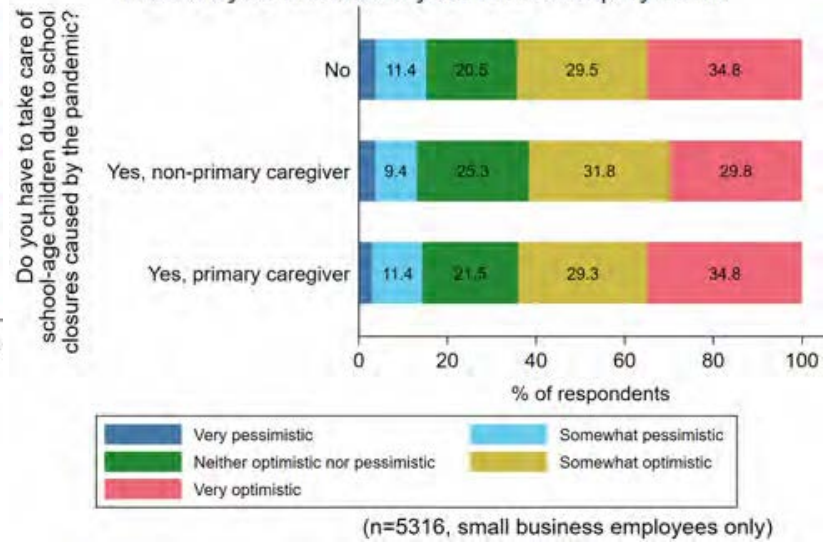

(F) Optimism about Future Employment, by

Childcare due to School Closures 


\section{A.VII TABLES}

\section{Table A.1: Business Operations}

This table looks at how business sales vary by firm and owner characteristics. Businesses were asked "Comparing this business sales for the last 30 days (in 2020) with the same month last year (in 2019), are this business sales?". The dependent variable takes a value of one if the response was "Lower than last year". The omitted base groups are age - less than 1 year, industry - agriculture or mining, sales - business not operational in 2019, in-person interactions - more than half of the interactions are in-person, and gender - female-owned or managed.

\begin{tabular}{|c|c|}
\hline & Lower sales \\
\hline Age - Between 1 and 2 years & $\begin{array}{l}0.371^{* * * *} \\
(0.040)\end{array}$ \\
\hline Age - Between 2 and 5 years & $\begin{array}{c}0.423^{* * *} \\
(0.036)\end{array}$ \\
\hline Age -5 years or more & $\begin{array}{c}0.442^{* * *} \\
(0.033)\end{array}$ \\
\hline Construction & $\begin{array}{c}0.170^{* * * *} \\
(0.062)\end{array}$ \\
\hline Hotels, cafes, and restaurants & $\begin{array}{c}0.355^{* * *} \\
(0.058)\end{array}$ \\
\hline Information and communication & $\begin{array}{c}0.175^{* * *} \\
(0.058)\end{array}$ \\
\hline Manufacturing & $\begin{array}{c}0.216^{* * *} \\
(0.070)\end{array}$ \\
\hline Other & $\begin{array}{c}0.216^{* * * *} \\
(0.052)\end{array}$ \\
\hline Retail and wholesale trade & $\begin{array}{c}0.199 * * * \\
(0.053)\end{array}$ \\
\hline Services & $\begin{array}{c}0.258^{* * *} \\
(0.051)\end{array}$ \\
\hline Transportation and logistics & $\begin{array}{c}0.297^{* * * *} \\
(0.069)\end{array}$ \\
\hline Sales less than $\$ 50,000$ & $\begin{array}{c}0.118^{* * *} \\
(0.035)\end{array}$ \\
\hline Sales between $\$ 50,000$ - $\$ 999,999$ & $\begin{array}{c}0.190^{* * *} \\
(0.040)\end{array}$ \\
\hline Sales $\$ 1,000,000$ or more & $\begin{array}{l}0.072^{*} \\
(0.043)\end{array}$ \\
\hline $\begin{array}{l}\text { In-person interactions - Half } \\
\text { or less }\end{array}$ & $\begin{array}{l}-0.083^{* * *} \\
(0.018)\end{array}$ \\
\hline Male-owned or managed & $\begin{array}{c}0.000 \\
(0.018)\end{array}$ \\
\hline $\begin{array}{l}\text { Obs. } \\
R^{2}\end{array}$ & $\begin{array}{l}3,023 \\
0.132\end{array}$ \\
\hline
\end{tabular}




\section{Table A.2: Household Expenses}

This table looks at factors that affect payment of household expenses. The dependent variable takes a value of one if the respondent says "Difficult" or "Very difficult" when asked "In the past 30 days, how easy or difficult has it been to pay your household's usual expenses?". In Column 1, we focus on how business and owner characteristics affect ease of payments. In Column 2, we study how variation in personal financing affects the household. Business owners/ managers were asked "Which of the following sources of money do you personally have access to during the coronavirus (COVID19) pandemic?". Responses are coded as independent variables in Column 2. The omitted base groups are age - less than 1 year, industry - agriculture or mining, sales - business not operational in 2019, in-person interactions - more than half of the interactions are in-person, and gender female-owned or managed.

\begin{tabular}{|c|c|}
\hline & $\begin{array}{c}\text { Difficulty in } \\
\text { caring for household }\end{array}$ \\
\hline Age - Between 1 and 2 years & $\begin{array}{l}-0.000 \\
(0.039)\end{array}$ \\
\hline Age - Between 2 and 5 years & $\begin{array}{c}0.013 \\
(0.036)\end{array}$ \\
\hline Age -5 years or more & $\begin{array}{l}-0.028 \\
(0.034)\end{array}$ \\
\hline Construction & $\begin{array}{l}-0.011 \\
(0.052)\end{array}$ \\
\hline Hotels, cafes, and restaurants & $\begin{array}{c}0.144^{* * *} \\
(0.053)\end{array}$ \\
\hline Information and communication & $\begin{array}{l}-0.028 \\
(0.050)\end{array}$ \\
\hline Manufacturing & $\begin{array}{l}-0.040 \\
(0.055)\end{array}$ \\
\hline Other & $\begin{array}{l}-0.002 \\
(0.045)\end{array}$ \\
\hline Retail and wholesale trade & $\begin{array}{c}0.015 \\
(0.045)\end{array}$ \\
\hline Services & $\begin{array}{c}0.041 \\
(0.044)\end{array}$ \\
\hline Transportation and logistics & $\begin{array}{l}0.179^{* * *} \\
(0.063)\end{array}$ \\
\hline Sales less than $\$ 50,000$ & $\begin{array}{l}-0.026 \\
(0.048)\end{array}$ \\
\hline Sales between $\$ 50,000$ - $\$ 999,999$ & $\begin{array}{l}-0.067 \\
(0.051)\end{array}$ \\
\hline Sales $\$ 1,000,000$ or more & $\begin{array}{c}-0.227^{* * *} \\
(0.052)\end{array}$ \\
\hline $\begin{array}{l}\text { In-person interactions - Half } \\
\text { or less }\end{array}$ & $\begin{array}{c}-0.101^{* * *} \\
(0.016)\end{array}$ \\
\hline Male-owned or managed & $\begin{array}{c}0.008 \\
(0.016) \\
\end{array}$ \\
\hline $\begin{array}{l}\text { Obs. } \\
R^{2}\end{array}$ & $\begin{array}{l}3,944 \\
0.050 \\
\end{array}$ \\
\hline
\end{tabular}

\begin{tabular}{lc}
\hline \hline & $\begin{array}{c}\text { Difficulty in } \\
\text { caring for household }\end{array}$ \\
\hline Income from another business & $-0.053^{* * *}$ \\
& $(0.016)$ \\
Social Security & -0.040 \\
& $(0.025)$ \\
Unemployment insurance & $0.076^{* * *}$ \\
& $(0.027)$ \\
Pension or retirement & $-0.085^{* * *}$ \\
& $(0.020)$ \\
Real estate rent & $-0.081^{* * *}$ \\
& $(0.020)$ \\
Return from investments & $-0.081^{* * *}$ \\
& $(0.020)$ \\
Personal savings & $-0.093^{* * *}$ \\
& $(0.013)$ \\
Nob wages & $0.157^{* * *}$ \\
\hline Obs. & $(0.024)$ \\
& -0.043 \\
& $(0.029)$ \\
& $-0.220^{* * *}$ \\
& $(0.014)$ \\
\hline
\end{tabular}




\section{Table A.3: Time Spent on Household Activities}

This table looks at how much time employees/workers spend on household activities. We asked "How many hours per day do you spend on domestic or household care activities?" and coded their answers

0 - "Less than 1 hour", 1 - "Between 1 and 2 hours", 2 - "Between 2 and 3 hours",

3 - "Between 3 and 4 hours", 4 - "Between 4 and 5 hours", 5 - "Between 5 and 6 hours",

8 - "Between 6 and 10 hours", 12 - "Between 10 and 14 hours" and 14 - "More than 14 hours".

The regressors are gender, remote-work, gender $\mathrm{X}$ remote-work, age, area, education, firm sector, and having to take care of school-age children due to school closures. The coefficients for education and sector are omitted from the table to increase legibility. The omitted default values are female, remote work - not at all, older than 66, rural, and children - no, respectively.

\begin{tabular}{|c|c|c|c|c|c|c|}
\hline & \multicolumn{6}{|c|}{ Time spent on household activities } \\
\hline & $(1)$ & $(2)$ & (3) & $(4)$ & $(5)$ & $(6)$ \\
\hline Male & $\begin{array}{l}-0.396^{* * *} \\
(0.070)\end{array}$ & & & & & $\begin{array}{l}-0.273^{* * *} \\
(0.104)\end{array}$ \\
\hline $\begin{array}{l}\text { Remote work - Yes, some of the } \\
\text { time }\end{array}$ & & $\begin{array}{c}0.467^{* * *} \\
(0.091)\end{array}$ & & & & $\begin{array}{l}0.233^{* *} \\
(0.113)\end{array}$ \\
\hline $\begin{array}{l}\text { Remote work - Yes, all of the } \\
\text { time }\end{array}$ & & $\begin{array}{c}0.037 \\
(0.082)\end{array}$ & & & & $\begin{array}{l}-0.106 \\
(0.099)\end{array}$ \\
\hline $\begin{array}{l}\text { Male } \times \text { Remote work } \\
- \text { Yes, some of the time }\end{array}$ & & & $\begin{array}{l}-0.008 \\
(0.149)\end{array}$ & & & $\begin{array}{c}0.115 \\
(0.182)\end{array}$ \\
\hline $\begin{array}{l}\text { Male } \times \text { Remote work } \\
- \text { Yes, all of the time }\end{array}$ & & & $\begin{array}{l}-0.343^{* * *} \\
(0.131)\end{array}$ & & & $\begin{array}{c}0.066 \\
(0.155)\end{array}$ \\
\hline Age -56 to 65 & & & & $\begin{array}{l}-0.654^{* * *} \\
(0.202)\end{array}$ & & $\begin{array}{l}-0.729^{* * * *} \\
(0.230)\end{array}$ \\
\hline Age -46 to 55 & & & & $\begin{array}{l}-0.304 \\
(0.198)\end{array}$ & & $\begin{array}{l}-0.713^{* * *} \\
(0.229)\end{array}$ \\
\hline Age -36 to 45 & & & & $\begin{array}{l}0.338^{*} \\
(0.200)\end{array}$ & & $\begin{array}{l}-0.466^{* *} \\
(0.232)\end{array}$ \\
\hline Age -26 to 35 & & & & $\begin{array}{c}0.105 \\
(0.198)\end{array}$ & & $\begin{array}{l}-0.469^{* *} \\
(0.227)\end{array}$ \\
\hline Age -18 to 25 & & & & $\begin{array}{l}-0.308 \\
(0.209)\end{array}$ & & $\begin{array}{l}-0.490^{* *} \\
(0.238)\end{array}$ \\
\hline Age - Younger than 18 & & & & $\begin{array}{l}-1.003^{*} \\
(0.593)\end{array}$ & & $\begin{array}{l}-0.273 \\
(0.791)\end{array}$ \\
\hline Suburban & & & & & $\begin{array}{l}-0.199^{* * *} \\
(0.077)\end{array}$ & $\begin{array}{l}-0.008 \\
(0.080)\end{array}$ \\
\hline Urban & & & & & $\begin{array}{c}-0.182^{* *} \\
(0.090)\end{array}$ & $\begin{array}{c}0.098 \\
(0.095)\end{array}$ \\
\hline $\begin{array}{l}\text { Children - Yes, but I am not the } \\
\text { primary caregiver }\end{array}$ & & & & & & $\begin{array}{l}0.891^{* * *} \\
(0.121)\end{array}$ \\
\hline $\begin{array}{l}\text { Children - Yes, and I am the } \\
\text { primary caregiver }\end{array}$ & & & & & & $\begin{array}{l}1.805^{* * *} \\
(0.088)\end{array}$ \\
\hline Obs. & 9,157 & 8,215 & 7,404 & 9,922 & 9,648 & 7,167 \\
\hline$R^{2}$ & 0.012 & 0.009 & 0.010 & 0.019 & 0.009 & 0.092 \\
\hline
\end{tabular}

